\title{
Expression and organization of sarcomeric constituents during muscle cell differentiation
}

Citation for published version (APA):

Schaart, G. (1994). Expression and organization of sarcomeric constituents during muscle cell differentiation. [Doctoral Thesis, Maastricht University]. Datawyse / Universitaire Pers Maastricht. https://doi.org/10.26481/dis.19940127gs

Document status and date:

Published: 01/01/1994

DOI:

10.26481/dis.19940127gs

Document Version:

Publisher's PDF, also known as Version of record

\section{Please check the document version of this publication:}

- A submitted manuscript is the version of the article upon submission and before peer-review. There can be important differences between the submitted version and the official published version of record.

People interested in the research are advised to contact the author for the final version of the publication, or visit the DOI to the publisher's website.

- The final author version and the galley proof are versions of the publication after peer review.

- The final published version features the final layout of the paper including the volume, issue and page numbers.

Link to publication

\footnotetext{
General rights rights.

- You may freely distribute the URL identifying the publication in the public portal. please follow below link for the End User Agreement:

www.umlib.nl/taverne-license

Take down policy

If you believe that this document breaches copyright please contact us at:

repository@maastrichtuniversity.nl

providing details and we will investigate your claim.
}

Copyright and moral rights for the publications made accessible in the public portal are retained by the authors and/or other copyright owners and it is a condition of accessing publications that users recognise and abide by the legal requirements associated with these

- Users may download and print one copy of any publication from the public portal for the purpose of private study or research.

- You may not further distribute the material or use it for any profit-making activity or commercial gain

If the publication is distributed under the terms of Article $25 \mathrm{fa}$ of the Dutch Copyright Act, indicated by the "Taverne" license above, 
EXPRESSION AND ORGANIZATION OF SARCOMERIC CONSTITUENTS DURING MUSCLE CELL DIFFERENTIATION 
CIPIDATA KONINKLIJKE BIBLIOTHEEK, DEN HAAG

Scheart, Gerrit

Expression and organization of sarcomeric constituents during Tuscle cell differentiation / Gerrit Schaart.-

Maastricht: Universitaire Pers Maastricht

Thesis Maastricht. - With reff. - With summary in Dutch.

ISBN $90-5278 \cdots 118-4$

Subject headings: muscle differentiation 


\section{EXPRESSION AND ORGANIZATION OF SARCOMERIC CONSTITUENTS DURING MUSCLE CELL DIFFERENTIATION}

\section{PROEFSCHRIFT}

ter verkrijging van de graad van doctor aan de Rijksuniversiteit Limburg te Maastricht, op gezag van de Rector Magnificus, Prof. Dr. H. Philipsen, volgens het besluit van het College van Dekanen, in het openbaar te verdedigen op donderdag 27 januari 1994 om 14.00 uur

door

\section{Gerrit Schaart}

geboren op 22 februari 1960 te Elst (Gld.)

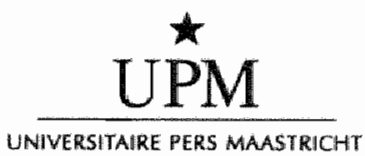




\section{Promotor:}

Prof. dr. F.C.S. Ramaekers

\section{Beoordelingscommissie:}

Prof. dr. G.J. van der Vusse (voorzitter)

Prof. dr. M. Borgers

Prof. dr. H.C. Hemker

Prof. dr. R.S. Reneman

Prof. dr. B. Wieringa (Katholieke Universiteit Nijmegen)

The investigations described in this thesis were carried out at the Department of Molecular Cell Biology \& Genetics, Cardiovascular Research Institute Maastricht (CARIM), University of Limburg, Maastricht, and partly at the Department of Pathology, University Hospital Nijmegen. 


\section{CONTENTS}

List of abbreviations

General Introduction

\section{Chapter 1:}

Desmin and titin expression in early postimplantation embryos

\section{Chapter 2:}

Baby hamster kidney $(\mathrm{BHK} 21 / \mathrm{C} 13)$ cells can express striated muscle type proteins

\section{Chapter 3:}

Differentiation of human skeletal muscle cells in culture:

maturation as indicated by titin and desmin striation

\section{Chapter 4:}

Characterization of cardiotin, a structural component in the myocard

\section{Chapter 5:}

Tissue-specific expression of a vimentin-desmin lhybrid gene in transgenic mice

\section{Chapter 6:}

Transgenic expression of the muscle-specific intermediate filament protein desmin in nonmuscle cells

\section{Chapter 7:}

Disruption of intermediate filaments by expression of dominant negative desmin mutants in transgenic mice

Summary/Samenvatting

Dankwoord

Curriculum vitae

Publications 


\section{ABBREVIATIONS}

BHK : baby hamster kidney

bp : basepairs

Da :Dalton

DMEM : Dulbecco's modified Eagle's medium

d.p.c. : days post coitum

EDTA : ethylenediaminetetra acetic acid

EMEM : Eagle's modified minimum essential medium

FCS : fetal calf serum

FITC : fluorescein isothiocyanate

GFAP : glial fibrillary acidic protein

$\mathrm{HBE}$ : human brain extract

$\mathrm{IF}(\mathrm{s}) \quad$ : intermediate filament(s)

IFP(s) : intermediate filament protein(s)

$\mathrm{kbp}:$ kilobasepairs

kDa : kiloDalton

NaDOC : sodium deoxycholate

PAA : polyacrylamide

PBS : phosphate buffered saline

PMSF : phenylmethylsulfonyll fluoride

SDS : sodiumdodecyl sulphate

SR : sarcoplasmic reticulum

TR : Texas red

TRITC : tetrametylirhodamine isothiocyanate 


\section{GENERAL INTRODUCTION}




\section{GENERAL INTRODUCTION}

Muscle cells are of mesodermal origin. Three types of muscle tissue may be distinguished in mammals on basis of morphologic and functional characteristics [28]:

1. Smooth muscle tissue consists of collections of fusiform cells, which do not show intracellular striation. Smooth muscle cells normally exhibit relatively slow uncontrolled contractions, and are for example found in the large and small intestine, the esophagus, the stomach and around blood vessels.

2. Skeletal muscle is composed of bundles of very long, cylindric, and multinucleated cells that show cross-striations. Their contraction is quick, forceful, and usually under voluntary control. Skeletal muscle cells comprise the somatic musculature of body wall and extremities.

3. Cardiac muscle is composed of elongated or branched individual cells that often run parallel to each other and show cross-striations. Individual cardiomyocytes are linked to each other at the intercallated disks, structures only found in cardiac muscle. Cardiac muscle is involuntary, vigorous, "and rythmic.

The sarcoplasm of both types of striated muscle cells contains long, cylindrical filamentous bundles called myofibrils, which have a diameter of $1-2 \mu \mathrm{m}$ and run in the long axis of the muscle cell. Myofibrils consist of sarcomeres, the contractile units of striated muscle cells.
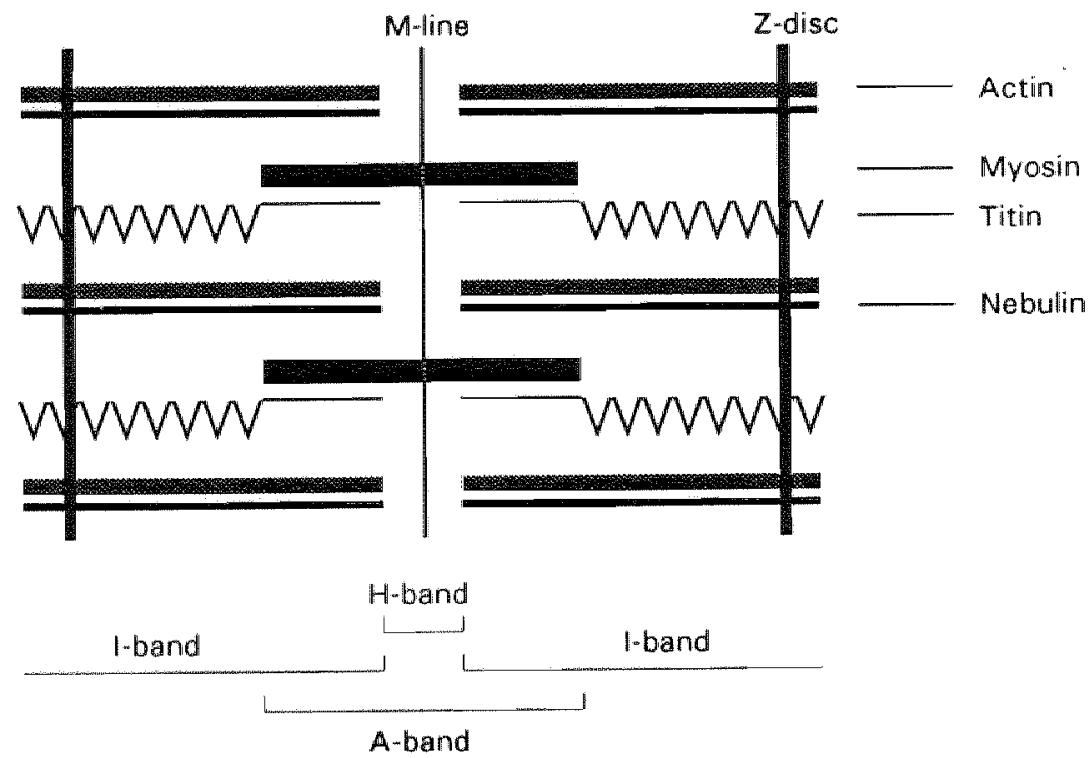

Figure 1: Schematic drawing of a striated muscle sarcomere

\section{Sarcomeric structure}

When mxamined by light microscopy, sarcomeres show regular dark and light bands, called A-bands and I-bands, respectively. A narrow line, the Z-disc borders at both sides of a sarcomere. With the electron microscope two types of filaments become evident in 
sarcomeres, i.e. thick filaments (15 nm) known to consist of myosin, and thin filaments $(8 \mathrm{~nm})$ containing actin, tropomyosin, and troponin. Thick and thin filaments averlap for some distance within the A-band. In the center of the A-band a lighter zone can be seen. called the H-band, which consists of only thick filaments, this in contrast to the I-bend that is mainly composed of thin filaments. The M-line lies in the certre of the H-band.

\section{Molecular composition of the sarcomere}

In the sarcomere the functional proteins mentioned above are strictly organized $\left[10,15 \|^{2}\right.$ The two major proteins of the sarcomere, myosin with an approximate molecular weight (MW) of $200 \mathrm{kDa}$ and actin (MW: $42 \mathrm{kDa}$ ). together represent $55 \%$ of the total protein content of striated muscle [28], and drive contraction [15].

The $95 \mathrm{kDa}$ protein $a$-actinin $[8,12]$, a major component of the $Z$-disc, is thought to anchor the actin filaments to this region. The intermediate filament protein desmin $\mathbb{M W}$ : $53 \mathrm{kDa}$ ). located in the outer circumference of the Z-disc, keeps the sarcomeres in register by linking the myofibrils to each other or to the sarcolemma $[23,50,51]$. In cardiac muscle desmin is not only observed in the Z-disc, but also in the intercalated disc. in clase association with the desmosomes [16]. Like desmin also a-actinin is present in the intercalated disc.

Two muscle-specific, giant sarcomeric proteins i.e. titin (MW: approximately $3.000 \mathrm{kDa}$ ) $[36,37]$ and nebulin (MW: approximately $800 \mathrm{kDa})[60]$, play probably an important role in regullating assembly of thick and thin filaments, respectively $[18,34,56,63]$. Titin molecules, found in both skeletal and cardiac muscie are over $1 \mu \mathrm{m}$ long $[181$, and span the distance from M-line to Z-disc [19]. The titin protein comprises about $10 \%$ of the myofibrillar mass [55]. Titin filaments may play an important role in elasticity and enzymatic activity of the myofibrils [56], as well as in maintaining the alignment of myosin filaments $\$ 261$. Nebulin is found in skeletal muscle and not in cardiac muscle, and acts as a protein-ruler, precisely regulating thin filament assembly $[27,33,34]$.

Other sarcomeric proteins are the actin associated proteins [15] such as tropomyosin (MW: $35 \mathrm{kDa}$ ) [6, 29], troponin I and troponin T (MW: $22 \mathrm{kDa}, 37 \mathrm{kDa}$, respectivelly) [9], and vinculin (MW: $130 \mathrm{kDal}[39$ ].

The contractile proteins of striated muscle described above are often represented by

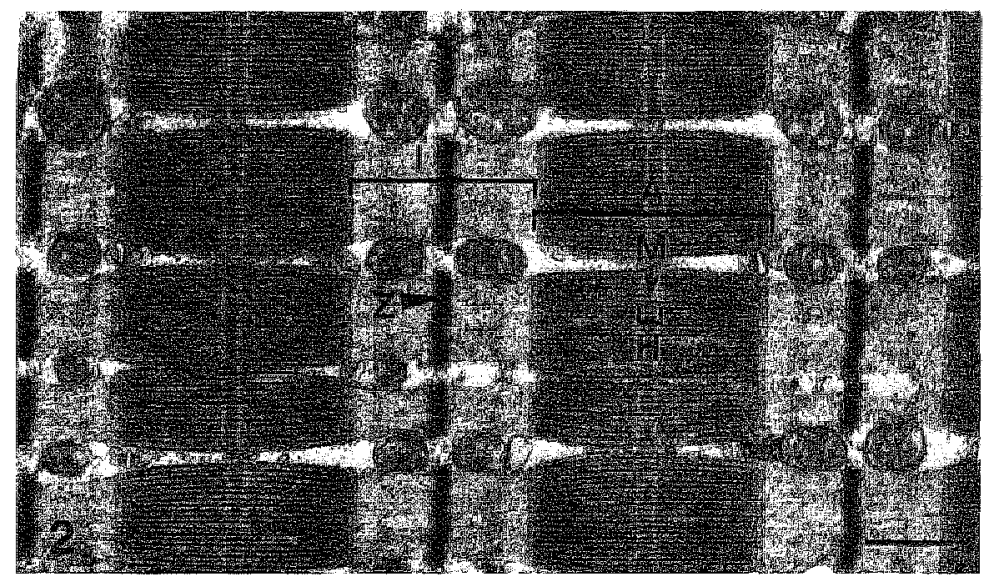

Figure 2: Electron microscopic photograph of human sketetal muscle sarcomeres. Bar indicates $600 \mathrm{~mm}$. Z: Z-disc; A: A-band; I: I-band; H: H-band; M: M-line. IPhotograpth kindly prowded by Dr. Paul Jap, Department of Cell Biology \& Histology, University of Migmegen, The Netherlends 
families of wery similar isoforms, which are functionally unique in developing and mature muscie cells [2].

\section{Differentiation related protein expression and assembly in wivo and in vitro}

During in wivo and in vitro myogenesis of smooth, skeletal, and cardiac muscle cells, different sets of muscle specific proteins and intermediate filament proteins occur precisely at different stages of differentiation, in an ordered sequence $[1,2,10,411,15$, $19,24,25,46,47,52,53,56,57,58,59,61,621$.

Intermediate filament proteins are expressed in early stages of myogenesis $[15,46,54$, 571 where keratins are the first expressed in embryogenesis. During further differentiation keratin expression decreases and is superceded by expression of another intermediate filament protein, usually vimentin [54]. Vimentin is found in presumptive replicating myoblasts or stages of development when desmin is still undetectable [21]. Desmin is found in all muscle cell types and can coexist with vimentin in early stages of myogenesis $[20,46,57,58]$. In general, however the concentration of desmin increases during the differentiation process of myocytes in wivo and in vitro. when the vimentin filaments gradually disappear $[3,15,40,46,52,57,58]$. After myofibril assembly in skeletal and cardiac muscle, desmin is distributed in a cross-striated pattern, situated in the Z-line and the intercalated disc $[4,38,46,47,57,58]$.

Titin is expressed in a characteristic punctate fashion even before desmin appears in differentiating myoblasts. This phenomenon is described for elongating skeletal muscle and myocard cells in vivo and in vitro $[7,20,25,46,53,57]$. During the differentiation process, when myoblasts form myotubes, the titin spots rearrange from a random distribution to a localization associated with the myofibrils, which contain sarcomeric $a$ actin and a-actinin, but not desmin or myosin 158,59$]$. Further in the differentiation process assembly of titin molecules into the sarcomeres of skeletal and cardiac muscle cells takes place, indicated by the typical cross-striated pattern seen with antibodies to titin $[18,20,46,58]$. After the appearence of titin cross-striations other muscle specific proteins, such as desmin, tropomyosin and myosin assemble into the sarcomere in an ordered fashion [46, 58, 59]. Apparently titin serves as a template for assembly of other sarcomeric proteins during myofibrillogenesis. At later stages of development nebulin is intergrated in the already formed sarcomeric structures of skeletal muscle cells [20, 59].

\section{Transgenic mouse models for the study of muscle protein function}

Transgenic mouse models have been used to study the function of muscle proteins [14] and that of intermediate filament proteins in particular. Modified hamster desmin genes, driven by hamster vimentin and hamster desmin promoters, were introduced into the germ line of mice [32, 41]. Since intermediate fillament proteins are expressed in a developmentally regulated and tissue specific fashion, alterations in highly conserved protein domains, that may be of crucial importance for proper functioning of intermediate filaments, are presumed not to be tolerated in normally functioning cells. The amino acid sequence of the carboxy-terminal domain of vimentin and desmin are much more conserved among species than the sequence of the amino-terminal domain and approximates the conservation of the rod domain $[42,64]$. The amino-terminal part of the different intermediate filament subunits seems to be of major importance in regulating fillament assembly $15,13,17,30,49,54]$ and vimentin or desmin gene constructs containing modifications or deletions in the carboxy-terminal part of the $a$-helical "rod" domain, disrupt intermediate filament networks in cultured cells in a dominant-negative fashion. This disruption of the intracellular intermediate filament networks can accur without affecting cell morphology, motility, or cell division $[22,31,35,43,44,45,48 \rrbracket$. 
Untill now, no developmental or morphological abnormalities could be detected in transgenic mice using truncated desmin and vimentin genes.

\section{Aim of this study}

To understand the process of assembly of muscle-specific proteins during myofibrillogenesis in vivo and in vitro and the interaction between these proteins in different stages of muscle development. Immuno-localization studies were performed in differentiating muscle cell cultures, as well as in mouse embryos and normal adult tissues of different species.

Moreover, to study the correlation between the function and molecular organization of these molecules, transgenic mice with a disorganized intermediate filament pattern were extensively studied at different molecular and morphological levels.

\section{REFERENCES}

1. Bader D, Masaki T, Fischman DA. Immunochemical analysis af myosin heavy chain during avian myogenesis in vivo and in witro. J. Cell Bito. 95, 763.770, 1982.

2. Bandman E. Contractile protein ìsoforms in muscle development. Dew. Biol. 154, 273-283, 1992.

3. Barbet JP. Thornell L-E, Butler-Browne GS. Immunocytochemical characterisation of two generations of fibers during the development of the human quadriceps muscle. Mach. Dev, 35, 311. 1991.

4. Bennett GS, Fellini SA, Holtzer H. Immumofluorescent visualization of 100 A filaments in differint cultured cell types. Differentiation $12,71-82,1978$.

5. Bloemendal $H$, Pieper FR. Intermediate filaments: known structure, unknown function. Biochim. Blophys. Acta 1007, 245-253, 1989.

6. Bronson DD, Schachat FH. Heterogeneity of contractile proteins. Differences in tropomyosin in fast, mixed, and slow skeletal muscles of the rabbit. J. Bioch.Chem. 257, 3937-3944, 1982.

7. Colley NJ, Tokuyasu KT, Singer SJ. The early expression of myofibrillar proteins in round post mitotic myoblasts of embryonic skeletal muscle. J. Cell Sci. 95, 11-22, 1990.

8. Ebashi S, Ebashi F, Maruyama K.. A new protein factor in promoting contraction of actomyosin. Nature 203, 645-647, 1964.

9. Ebashi S, Endo M. Calcium lon and muscle contraction. Prog. Biophys. Mol. Biol. 18, 123m 183, 1968.

10. Epstein HF, Fischman DA. Molecular analysis of protein assembly in muscle development. Science $251,1039-1044,1991$.

11. Epstein HF, Bernstein SI. Genetic approaches to understanding muscle development. Dev, Biol. $154,231-244,1992$

12. Etlinger JD, Zak $R$, Fischman DA. Compositional studies of myotibrils from rat striated muscle. J. Ciell Biol. 68, 123-141, 1976 .

13. Evans RM. Phosphorylation of vimentin in mitotically selected cells. In vitro cyclic AMP. independent kn̈nase and calcium stimulated phosphatasé activitles. d. Cell Biol. 108, 67.78, 1989.

14. Field LJ. Transgenic mice in cardiovascular research. Annu. Flev. Physiol 55, 97-114, 1993.

15. Fischman DA. Myofibrillogenesis and the morphogenesis of skeletal muscle. In: Mvology. Basic and Chinical. leds. Engel AG, Banker BO) McGraw.Hill, New York, pp 5-30, 1986.

16. Franke WW, Winter S, Grund C, Schmid E, Schiller DL, Jarasch ED. Isolation and chanacterization of desmosome-associated tonofilaments from rat intestinal brush border. J. Cell Biol. 90, 116 127, 1981 .

17. Fraser $R$, Steineft PM, Stewen AC. Focus on hintermediate filaments. Trends Biocti. Sci. 2, 43-45, 1987.

118. Futton $A B$, Isaacs WB. Titin, a muge, elastic sarcomeric protein with a probable rola in marphogenesis. BioEssays 13, 157-161, 1991.

19. Fürst DO, Osborn $M$, Nawe $R$, Weber $K$. The organization of thin filaments in the half-sarcomere revealed by monoclonal antibodies in immunoelectron microscopy: a map of ten nonrepetitive epitopies starting at the $Z$ line extends to the $M$ line. J. Cell Biol. 106, 1563-1572, 1988.

20. Furst DO, Osborn $M$, Weber $K$. Myogenesis in the mouse embryo: differential onset of expression of myogenic proteins and the unvolwement of titin in myofibril assembly. J. Cell Biol 109, 517 . 
527,1969

21. Gurd $\mathrm{DL}$, Latardes $\mathrm{E}$. The synthesis and ditrbution of desmin and wimentin during myogenesis in vitro. Cell $19,263-275,1980$.

22. Gill $\mathrm{SR}$, Wong $\mathrm{PC}$, Monteiro MJ, Crevelland DW. Assembly properties of dominant and recessive mutations in the small mouse meurofiament (NF-L) subunit. J. Cetl Biol. 111, 2005-2019, 1990.

23. Granger $\mathrm{EL}$, Lazarides $\mathrm{E}$. Desmin and wimentin coexist at the periphery of the myotibril $\mathbb{Z}$-disc. Cell 18. $1053-1063,1979$.

24. Handel SE, Greaser ML, Schuftz E, Wang SM, Dulnsk JC, Lin JUC, Lesisard JL. Chicken and cardiac myofibrillogenesiss studied whth antibodies specific for fitin and the muscle and nonmuscle isoforms of actin and tropomyosin. Cell. Tissue Res. 263,419-430, 1991.

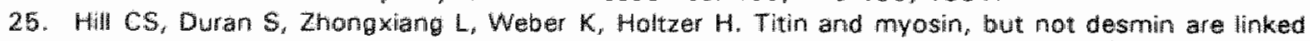
during myatibrilogenuesis in postmitatic mononucleated myoblasts. . Cell Bial. $103,2185-2196$, 1986.

26. Honowits A, Podolsky AJ. The positional stability of thick hilaments in actiwated skeletal muscle depends on warcomere length: evidence for the role of titin filaments. J. Cell Bial, 105, 2217. 2223,1987

27. Jin J-P, Wang K. Cloning, expression, and protein interaction of human mebulin fragments composed of warying numbers af sequence modules. J. Biol. Chem. 226, 21215-21223, 1991.

28. Junqueira LC, Carneiro J, Long JA. Basic Hisfology. Lange Medical Publications, 5th adition, Los Altos, Callfornia, USA, pip 234-254, 1986.

29. Kardami E, Montarras D, Fisiman MY. Fast and slow chicken skeletal muscle contain different $a$ and B-tropomyosins. Biophys. Res. Commun. 110, 147-154, 1983.

30. Kaufmann $E$, Weber $K$, Geisler N. Intermediate filament forming abilly of desmin derivatives lacking either the amino-terminal 67 or the carboxy-terminal 27 residues. J. Mol. Biol. 185, 733. $742,1985$.

31. Klymkowsky MW, Bachant JB, Domingo A. Functions of interemdiate filaments. Cell Motil. Cytoskel. 14,309-331, 1989.

32. Krimpenfort PJ, Sichaart $G$, Pieper FA, Ramaekers FC, Cuypers HT, Van den Heuvel RM, Vree Egberts WT, Vant Eys GJ, Berns A, Bloemendal H. Tissue specific expression of a vimentin-desmin hybrid gene in transqenic mice. EMBO J. 7, 941-947, 1988.

33. Kruger $M$, Wright J. Wang K... Nebulin as a length regulator of thin filaments of vertebrate skeletal muscles: Correlation of thin filament length, nebulin slize, and epitope profile. J. Cell Biol. 115,97$107,1991$.

34. Labeit $S$, Gibson $T$, Lakey $A$, Leonard $K$, Zeviarii $M$, Knight $P$, Wardale J, Trinick J. Evidence that nebulin is a protein-ruler in muscle thin filarnents. FEBS 282, 313-316, 1991.

35. Letai $A$, Coulombe PA, Fuchs $E$. Do the ends justify the mean? Proline mutations at the ends of the keratin coiled coill rod sepment are more disruptive than internal mutations. $J$. Cell Biol. 116 , 1181-1195, 1992.

36. Maruyama $K$, Natori $R$, Nanomura $Y$. New elastic protein from muscle. Nature 262, 58-60, 1976.

37. Maruvama K. Connectin, an ellastic filamentous protein of striated muscle. Int. Rev. Cytol. 104, $81.114,1986$.

38. McFerin J, Askarnas V. Engel WK. Expression of desmin in human muscle cuttured aneurally and innerwated by fatal rat spinal cord neurons. J. Neurol. Sci. [Suppl.] 98, 193, 1992.

39. Otto JJ. Vinculin. Cell Motil. Cytoskel. 16, 1.6, 1990.

40. Peper FA, Slobbe RL, Ramakers FCS, Cuypers HT, Bloemendal H. Upstream regions of the hamster desmin and vimentin genes regulate expression during in witro myogenesis. EMBO J. 6 , $3611-3618,1987$.

41. Pleper FA, Schaart G, Krimpenfort PJ, Henderik JB, Mashage HJ, Wan de Kemp A, Ramaekers FCS, Berns $A$, Bloemendal $H$. Transentc expression of the muscle-specific intermediate filament protein desmin in nonmuscle colls. J. Cell Biol. 108, 1009-1024, 1989.

42. Quax $W$, Van den Hewvel $R$, Vree Egberts $W$, Quax-Jeuken $Y$, Bloemendal H. Intermediate filaments cQNAs from BHK-21 cells: demonstration of distinct genes for desmin and vimentin in all wertebrate classes. Proc. Nat. Acad. Sci. USA 81, 5970.5974, 1984.

43. Raats JM, Pieper FR, Vree Egberts WT, Verrîp KN, Ramaekers FCS, Bloemendal H. Assembly of amino-terminally deleted desmin in vimentinufree cells. J. Cell Biol. 111, 1971-1985, 1990.

44. Aaats JM, Henderik JB, Verdik M, Van Oort FL, Gerards WL, Ramaekers FCS, Bloemendal H. Assembly of carboxy-terminally deleted desmin in vimentin-free cells. Eur, J. Cell Biol. 56, 84$103,1991$.

45. Raats JM, Gerrards Wh, Scheuder MI, Grund C, Henderik JB, Hendriks IL, Ramaekers FCS, Bloemendal $H$. Biochemical and structural aspects of transiently alnd stably expressed mutant desmin in wimentin-free and wimentin-containing cells. Eur. J. Cell Biol. 58, 108-127, 1992. 


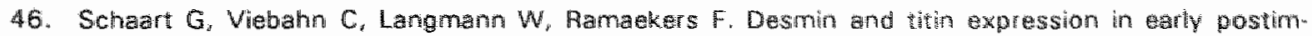
plantation mouse embryos. Development $107,585-596,1989$.

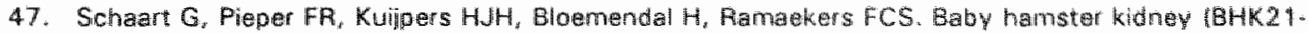
$1 \mathrm{C} 13$ i cells can express striated musche type proteins. Offerentiation $46,105,115,1991$

48. Schwiheiss T, Lin Z, Ishikawa H, Zami! I, Stoeckert C. Holtzer H. Desminhimentin internediate filaments are dispensable for many aspects of myogenesis. J. Cell Biol. 114,953-966. 199.

49. Steinert PM, Poop DR. Mollecular and cellular biology of intermediate fildments. Annu. Rev. Bochem. 57, 593-625, 1988.

50. Tokuyasu $\mathrm{K}_{\mathrm{n}} \mathrm{T}$, Dutton $\mathrm{AH}$, Singer SF. Immumoelectron microscopic studies of desmin $\|$ skeletinl. localization and intermediate thament organization in chicken skeleton musclo. J. Coll Biol. 96, $1727-1735,1983$

51. Tokuyasu KT, Dutton AH. Singen SF. Immunoelectron microseapic studies of desmin (sikeletin). tocalization and intermediate Hilament organization in chicken cardiac muscle. J. Cell Biol. 96. $1736-1742,1983$.

52. Tokuyasu KT. Maher PA, Singer SJ. Distributions of vimentin and desmin in developing chick myotubes in wivo. I. Immunofluorescence study. J. Cell Biol. 96, 1961-1972, 1984.

53. Tokuyasu KT, Maher PA. Immunocytochemical studies of cardiac myofibrillogenesis in early chick embryos. 1. Presence af immunofluorescent spots in premyofibril stages. J. Cell Biol. 105, 2781$2793,1987$.

54. Traub P. Intermediate Filaments: A Review. Springer Verlag Berlin. 1985.

55. Trimick J Knight P. Whiting A. Purification and properties of mave titin. J. Mol, Biol. $180,331$. $356,1984$.

56. Trinick J. Understanding the functions of titin and nebulin. FEBS 307, 44-48, 1992.

57. Van der Loop FTL, Schaart G, Langmann W, Ramaokers FCS, Viebahn C. Expression and organzation of muscle specific proteins during the early developmental stages of the rabbit heart. Anat. Embryol. 185, 439-450, 1992 .

58. Van der Ven PFM. Schaart G, Jap PHK, Sengers RCA, Stadhouders AM, Ramaekers FCS. Differentiation of human skeletal muscle cells in culture: maturation as indicated by titin and desmin striation. Cell Tissue Res. 270, 189-198, 1992.

59. Van der Ven PFM, Schaart G, Croes HJE, Jap PHK, Ginsel LH, Ramaekers FCS. Titin aggregates associate with stress fiber-like structures in cultured differentiating human skelelal muscle cells. J. Cell Sci., in press, 1993 .

60. Wang K. Ramirez-Mitchell R. Identification of a N2-line protein of striated muscle. Proc. Natl. Acad. Sci. USA 77, 3254-3258, 1980

61. Wang SM, Greaser ML, Schultz E, Bullinski JC, Lin JJC, Lessard JL. Studies on cardiac myofibrillogenesis with antibodies to titin, actin, tropomyosin, and myosin. J. Cell Biol. 107, 1075-1083, 1989.

62. Wessels $A$, Vermeullen JLM, Virágh Sz, Kálmán F, Lamers WH, Moorman AFM. Spatial distribution of "tissue-specific" antigens in the developing human heart and skeletal muscle. II. An immunohistochemical analysis of myosin heavy chain isoform expression patterns in the embryonic healt. Anat. Rec. 229, 355-368, 1991.

63. Whiting $A$, Wardale $J$, Trinick $J$. Does titin regulate the length of muscle thick filaments? $J$. Cont Biol. 205, 263-268, 1989

64. Zehner ZE, Li Y, Roe BA, Paterson BM, Sax CM. The chicken vimentin gene. Mucleotidw sequencer, regulatory elements, and comparison to the hamster gene. J. Biol. Chem. 262, 8112-8420, 1987. 


\title{
CHAPTER 1
}

\section{DESMIN AND TITIN EXPRESSION IN EARLY POSTIMPLANTATION MOUSE EMBRYOS}

\author{
G. SCHAART, C. VIEBAHN, W. LANGMANN \\ and F.C.S. RAMAEKERS
}

Development 107, 585-596, 1989 


\section{AESTRACT}

The expression of the intermediate filament (fF) constituents desmin, wimentin and keratin, as well as the striated-muscie-specific marker titin. was studied in mouse ambryos of 8.0 to 9.5 days post coitum (d.p.c.), using the indirect immunofluorescence technique in combination with polyclonal and monoclonal antibodies. During the development of the embryo, desmin was first detected at 3.25 d.p.c. in the ectoderm. where it was transiently coexpressed with keratin and vimentin. At later stages, the ectoderm contained only keratin and to a certain extent also vimentin IF. At 8.5 d.p.c., desmin was found exclusiwely in the heart rudiment, and remained present with increasing intensity in the myocardial cells during later cardiogenesis. Striation of desmin in the heart muscle cells was observed in 9.5 d.p.c. embryos. At these stages $(8.5-9.5$ d.p.c.l, triple expression of the IF proteins desmin, vimentin and keratin was evident in these cells. From 9.0 d.p.c. onwards, desmin could be detected in the myotomes as well. Immunoblotting studies of 9.5 d.p.c. mouse embryos confirmed the immunohistochemical data.

Titin was found in the early heart anlage at stage 8.25 d.p.c., when no desmin expression was observed in this tissue. At this stage the titin appeared in a punctate pattern, similar to that observed in cardiac myofibrils of early chicken embryos (Tokuyasu and Maher: J. Cell Bicl. 105, 2781-2793, 1987). In 8.5 d.p.c. mouse embryos, this punctate titin staining pattern was still observed, while, at this stage, a filamentous staining reaction could be seen with the desmin antibodies. During further development, cross-striation was detected within myocardial cells using the polyclonal titin antibody from 9.0 d.p.c. onwards, i.e., before such striation could be detected with the desmin antibodies.

From these data, we conclude that titin synthesis may anticipate desmin expression in the developing mouse myocard, although the level of expression of the former protein remains low until 9.0 d.p.c.

\section{INTRODUCTION}

The protein constituents of intermediate-sized filaments of the cytoskeleton in cells of adult animals have been described to be expressed in a more or less tissue-specific fashion [33]. Keratin normally occurs only in epithelial tissues, while neurofilaments and glial fibrillary acidic protein (GFAP) are mainly restricted to neural cell types [5, 39; for review see: 15]. Desinin has so far been found to be virtually muscle specific 16 ; for exceptions see: 10,271, while vimeritin occurs in cells of mesenchymal origin, but is also occasionally coexpressed with the other intermediate filament proteins (IFP) [9]. The expression of IFP in developing embryos has been studied by several investigators. Isee review: 461. From these results, it has become obvious that apart from the lamins, cytokeratins are the first cytoplasmic IFP to be expressed in early embryogenesis [18]. Embryonal cells containing this type of IFP are multipotential in nature and switch on the expression of vimentin when differentiating into mesenchymal cells $[9,46]$. Subsequentily, differentiation into mature cells results in the expression of the more specific IFP. such as desmin in muscle cells and GFAP in glial cells. However, coexpression of vimentin with these IFP is seen during embryagenesis and even after birth $\llbracket 24,31,381$. During myogenesis vimentin and desmin are expressed in sequence in differentiating myocytes $[8]$. In replicating myoblasts, vimentin is found in early stages of development at which desmin is undetectable. When the myogenic cells withdraw from the cell cycle at an early stage of myofibrillogenesis, desmin expression is initiated [8]. As muscle cell differentiation proceeds, desmin expression becomes more prominent, while its localization becomes more and more restricted to the outer circumference of the $Z$ band, both in skeletal and cardiac striated muscle cells $[4,8,14]$. Most of the work on 
IFP expression in muscle morphogenesis has concentrated on avian tissues $11,41,441$. while mammalian myofibrillogenesis has hardy been studied at this level. Since fundamental differences have, however, been noted during myogenesis in avians and mammals $[2,21]$, we have studied desmin and wimentin expression in mouse embrvos at 8.0 to 9.5 days post coitum (d.p.c.). It was postulated that during avian in wivo and in witro myofibrillogenesis desmin is one of the earliest krown markers for cells in the myogenic lineage and that proteins such as titin and myosin heavy chain occur later. We also studied the development of titin. which has been identified as a specific component in cardiac and skeletal muscle $[25,26,50]$.

\section{MATERIALS AND METHODS}

\section{Embryos}

The embryos used for this study were from spontaneous matings of mice of the C75bl/CBA (BCBA) strain. The presence of a vaginal plug indicated a successful mating. The conceptuses were thus presumed to be 0.5 days old at noon (12:00) on the day the vaginall plug was found. At $8.0,8.25,8.5,9.0$ and 9.5 days post coitum (d.p.c.) embryos were dissected from the uterus and washed in cold phosphate buffered saline (4. ${ }^{\circ}$ : PBS: $137 \mathrm{mM}$ sodium chloride (Merck, Darmstadt, FRG); $13 \mathrm{mM}$ di-sodium hydrogen phosphate dihydrate, $\mathrm{Na}_{2} \mathrm{HPO}_{4} \cdot 2 \mathrm{H}_{2} \mathrm{O}$ (Merck): $3 \mathrm{mM}$ potassium dihydrogen phosphate. $\mathrm{KH}_{2} \mathrm{PO}_{4}$ (Merck), $\mathrm{pH} 7.4$ ). Embryos were quickly frozen in liquid $\mathrm{N}_{2}$ after removal from the uterus and immersed in Tissue Tek (Miles Inc., Elkhart. INI, USA). The developmental stages are designated according to Theiler [42].

\section{Indirect immunafluorescence microscopy}

Five micrometer thick cryostat sections were air-dried, fixed with methanol (Merck) at $-20^{\circ} \mathrm{C}$ for $5 \mathrm{~min}$, followed by acetone (Merck) fixation at $-20^{\circ} \mathrm{C}$ for $1 \mathrm{~min}$. After air. drying for $15 \mathrm{~min}$ at room temperature, the sections were incubated with the primary antibody for 30 min at room temperature, and washed three times ( 5 min each) in PBS. Then they were incubated with the secondary antibody for $30 \mathrm{~min}$ at room temperature and again washed three times $(5 \mathrm{~min}$ each in PBS, for 5 min in distilled water and finally for $5 \mathrm{~min}$ in methanol. Sections were mounted in Mowiol (Hoechst, Frankfurt, FRG) containing $2.5 \%$ (w/v) $\mathrm{NaN}_{3}$ (Merck) to retard fading [19]. Slides were examined using a Zeiss Universal microscope equipped with epi-illumination optics.

\section{Gel electrophoresis and immunoblotting}

Cytaskeleton preparations from 9.5 d.p.c. mouse embryos were made as follows. After dissection of the embryos from the uterus, a high-salt buffer $(1.5 \mathrm{M} \mathrm{KCl}$ (Merck); $0.5 \%$ Triton X-100 (BDH Chemicals Ltd., Poole, UK); $5 \mathrm{mM}$ EDTA (Merck), $0.4 \mathrm{mM}$ phenylmethylsuifonyl tluoride (PMSF; Merck) and $10 \mathrm{mM}$ Tris.HCl (lMerck), $\mathrm{pH}$ 7.2) extraction was performed for 5 min at $4^{\circ} \mathrm{C}$ by homogenization of the embryo in a Dounce potter. The pellet obtained by centrifugation for 5 min at $12,000 \times g$ was washed with cold $\left(4^{\circ} \mathrm{C}\right)$ low-salt buffer $(5 \mathrm{mM}$ EDTA, $0.4 \mathrm{mM}$ PMSF and $10 \mathrm{mM}$ Tris-HCl, $\mathrm{pH} 7.2)$, essentially as described [281. After a second washing step in PBS, the cytoskeleton preparation was dissiolved by boiling for 5 min in SDS-sample buffer [23].

One-dimensional gel electrophoresis was performed in $10 \%$ polyacrylamide slab gels containing $0.1 \%$ SDS (BDH Chemicals Ltd. [23]. To compare the amounts of protein loaded on each lane, gels were stained with Coomassie Brilliant Blue R250 (Gurr. Hopkin 
and Wiliams, Chadwell Heath, Essex, UK) as described 131. Two-dimensional gel electrophoresis was performed essentially as described by 0 Farrell $[301$. In the first dimension, isoetectric focusing was performed in $4 \%$ polyacrylamide (Bio-Rad Laboratories. Richmond, CA, USA) rod gels containing 1\% Biolyte, pH 3.5 - 10 (Bio-Rad Laboratories). For the second dimension, the rod gels were applied directly onto the stacking gel of SDS-polyacrylamide gels.

For immunoblotting experments, the electrophoretically separated polypeptides were transferred to a nitrocellulose sheet (Schleicher \& Schuell Membrane Filters BA 85. Dassel, FRG) by blotting for 1 h at $100 \mathrm{~V}$ in a cold $\left(4^{\circ} \mathrm{C}\right)$ buffer containing $25 \mathrm{mM}$ TRIS$\mathrm{HCl}, 192 \mathrm{mM}$ glycine (Merck). 0.02\% SDS and $20 \%$ methanal (pH 8.3) 1541. The blots were incubated for $90 \mathrm{~min}$ with PBS containing $0.05 \%$ Tween20 ISigma Chemical Company. St Louis. USAI. All reagents were diluted in this solution, which was also used for the washing steps. After incubation overnight with undiluted culture supernatants of the primary antibodies RD 301, RV202, CK18-2 or BV1118, the blots were washed three times for $10 \mathrm{~min}$ and incubated for $1 \mathrm{~h}$ with peroxidase conjugated rabit anti-mouse lig (DAKOpatts, Glostrup. Denmark) diluted 1:400. The blots were washed again three times for $10 \mathrm{~min}$ in $0.05 \%$ Tween20/PBS and once in PBS alone for $10 \mathrm{~min}$ and stained with 4chloro-1-naphtol (Merck) and $0.12 \%$ hydrogen peroxide (Merck). After staining the blots were rinsed for $5 \mathrm{~min}$ with water.

\section{Antibodies}

The following antibody preparations were used in this study:

1. A polycional antiserum to chicken gizzard desmin (pDes). Preparation and characterization of this rabbit antiserum have been described elsewhere [35]. For indirect immunofluorescence microscopy, this serum was diluted 1:50 in PBS.

2. Two mouse monoclonal antibodies to desmin (DE-B-5 and DE- R-11: DAKOpatts) [6]. These antibodies were used as undiluted culture supernatants in the imnumohistochemical assays.

3. A mouse monoclonal antiserum to desmin (RD301), giving a weak, although specific. reaction on muscle cells in adult and embryonic mouse when used in the indirect immunofluorescence assay. This antibody has been described before [32].

4. An affinity-purified polyclonal antiserum to bovine lens vimentin (pVim). Purification and characterization of this polyclonal rabbit antiserum thave been described in detail elsewhere [36].

5. A mouse monoclonal antibady (BV1 118 ) of the IgM subclass, reactive with vimentin of human, bovine, rabbit, hamster, mouse and chicken arigin $1 \mathrm{C}$. Viebahn, unpublished diatal. This antibody, when tested in the indirect immunofluorescence assay. stains tissues of mesenchymal origin such as fibroblasts, endothelial cells, some smooth muscle cells, glomeruli in the kidney, but does not stain mast adult epithelial cells. In cultured cells (BHK-21/C13. HeLai, a hlamentous staining pattern is obtained with antibody $\mathbb{B} V 1118$. No significant reaction is found in cultured cells such as T24, RT4 and MCF-7, known to be vimentin negative [13]. In one-and twodimensional immunoblotting assays of cytoskeletal extracts from bowine lens. BHK$21 / \mathrm{C} 13$ cells Fig. 11, and HeLa cells, this monoclonat antibody shows a positive reaction with a protein band migrating at the molecular weight llevel and isoelectric $\mathrm{pH}$ of vimentin. This antibody was used as undiluted culture supernatant in the immunohistochernical assays.

6. A mouss monoclonal antiserum to vimentin (RV202), giving a weak, although specific, reaction on stromal cells and other mesenchymal tissues in adult and embryonic mouse in the indirect immunofluorescence assay. was used for immunoblotting experiments. This antibody has been described in detail elsewhere $132.34,481$. 


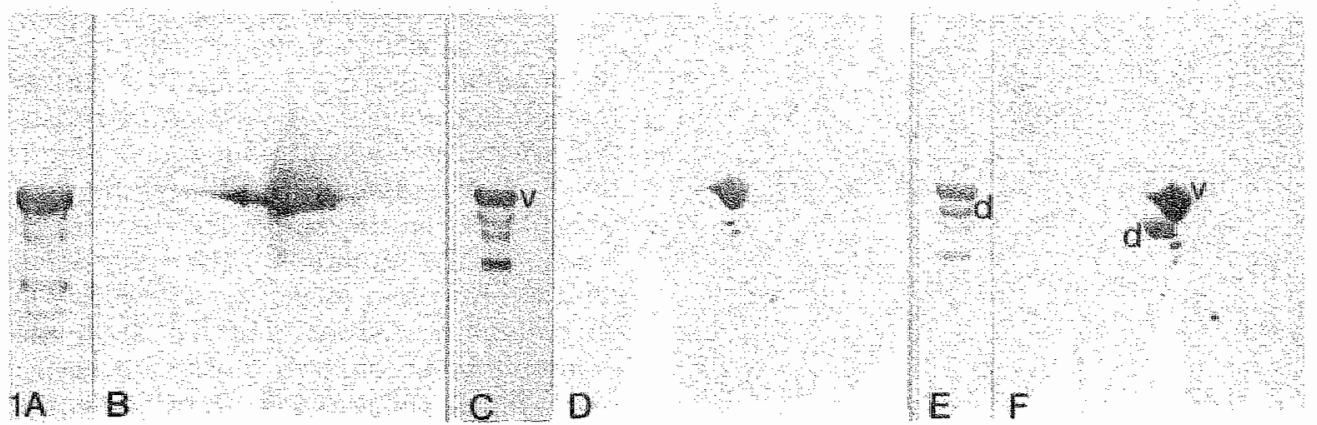

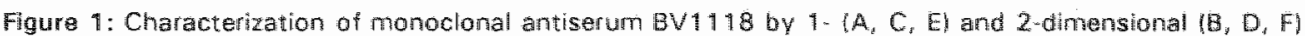
immunoblotting on cytoskeletal preparations of bovine lens $1 \mathrm{~A}$, B and $8 H \mathrm{H}-21 / \mathrm{C} 13 \mathrm{cells} \| \mathrm{C} \times \mathrm{F}$. Note that antiserum BV 1118 reacts exclusiwsly with vimentin $(W)$ and its breakdown products $(A-D)$, both from calt and hamster. Reincubation of the immunoblots with the monoclonal desmin antiserum (RD301: E, F) contirms the vimentim-specific reaction of antiserum BW1118. d: desmin

7. An affinity-purified polyclonal antiserum to human skin keratins (pker). This rabbit antiserum is described elsewhere [36]. For indirect immunofluorescence microscopy. this antiserum was diluted 1:10 in PBS.

8. A mouse monoclonal antibody (CK18-2) specifically recognizing cytokeratin 18 was raised against human mesothelial cells. This antibody was used as undiluted culture supernatant [3].

9. An affinity-purified polyclonal rabbit antiserum to titin, isolated from Physarum polycephalum (kind gift from Dr. D. Gassner, Bonn. FRG), was used in a $1: 25$ dilution. Preparation and specificity of this antiserum have been described by Gassner [11]. When tested on adult mouse tissues using the indirect immunofluorescence assay, this antiserum reacted specifically with striated (skelletaland cardiac-l muscle cells. No reaction was found in smooth muscle cells or in nonmuscle cells.

10. A polyclonal antiserum against human fibronectin was purchased from DAKOpatts and used at a dilution of $1: 120$.

As secondary antibodies fluorescein isothiocyanate (FITC)-conjugated goat anti-mouse IgG, goat anti-mouse $\mathrm{IgM}$ and goat anti-rabbit $\mathrm{lgG}$ were used in a dilution of 1:60. All FITC-conjugated antisera were obtained from Nordic Immunochemicals ITilburg. The Netherlands).

In order to prove that the correct protein constituents are recognized in mouse ambiyos, studies were performed with 9.5 d.p.c. embryos. Fig. 2 shows that with the monoclonal antisera to vimentin, desmin and keratin 18 , these individual components can be detected in cytoskeletal preparations from $9.5 \mathrm{~d}$.p.c. embryos.

\section{RESULTS}

The results obtained in the immunohistochemical studies, performed on mouse embryos of $8.0,8.25,8.5,9.0$, and 9.5 d.p.c.. are summarized in Table 1 and depicted in figures $3-9$.

\section{Presomite embryo (Theiler stage 11)}

At 8.0 d.p.c., the polyclonal antiserum pker shows a strongly positive reaction in the visceral endoderm. An extremely intense reaction with this antiserum was also observed 


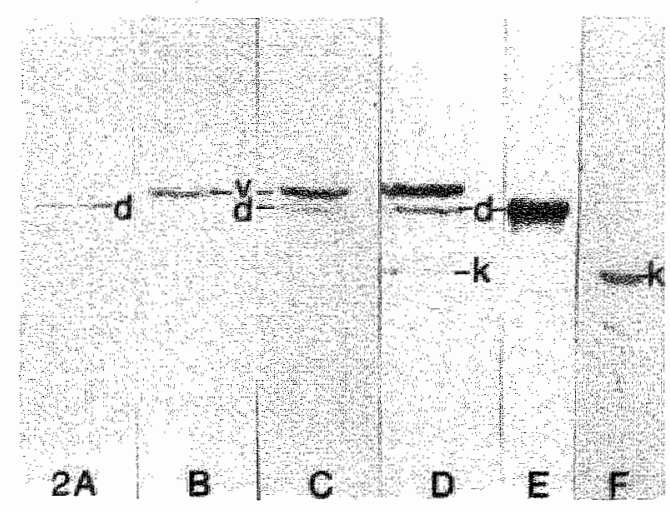

Figure 2: Immunoblotting study on cytoskeleta! preparations from 9.5 d.p.c. motuse embrvos llanes A.D). Immunio-blots were incubated as follows: lane A) with the monoclonal desmin anviserum (RD301/: lane B) with the monoclonal vimention antiserum (FV202); lane C) with RD 301 and subsequently with PV 202; lane Dy as lane $\mathrm{C}$, but thereafter incubated with the moncclonal keratin 18 antiserum (CK 18-2). For comparison, lane El depicts an immunoblot of a chicken gizzard desmin preparation incubated with AD301 and lame F) a cytoskeletal preparation of cell line FT4 incubated with CK18-2, to show the postition of desmin (d) and keratin 18 (k), respectively. v: vimentin. in the parietal endoderm, while the mesoderm and ectoderm were virtually negatiwe. Antibody CK 18-2 reacted in a similar fashion but weaker. The vimentin antiserum ( $p$ Vim) showed a pronounced reaction in the mesoderm, which was particularly obvious in the tangentially sectioned areas of the embryos. The polyclonal desmin antiserum (pDes) was negative in all embryonic tissues, but did stain the extraembryonic smooth muscle tissue of the uterus. Fibronectin was detected extracellularly in the embryonic mesoderm and in nonembryonic tissues, but not in the visceral endoderm and ectoderm. The polyclonal titin antiserum (pTitinl was also tested at 8.0 d.p.c. and found to be negative.

\section{Heart rudiment (Theiler stage 12)}

In the mouse, heart development starts in the midline as an umpaired anlage [21] rostral from the neural plate and caudal from the embryoniciextraembryonic junction [42]. This early stage of heart formation was studied in a 8.25 d.p.c.

embryo (Fig. 3) in which the heart-forming region can be seen to have bent ventrally in order to form the foregut pocket. In the sagittal sections through this region, we have observed no reaction, or at best an extremely weak staining reaction, with the desmin polyclonal antiserum (pDes; Fig. 3A). However, the basal plate of the neuroectoderm overlying the foregut pocket dorsally showed a positive staining reaction with the desmin antiserum while the mesoderm and endoderm were negative. Using a polyclonal titin antiserum ( $p$ Titin), single positive dots were observed in the heart rudiment (Fig. 3B). The mesoderm, the ectaderm, the endoderm and the foregut pocket were negative. The vimentin monoclonal antiserum (BV1118; Fig. 3C) and the polyclonal antiserum against vimentin (pVim) were positive in the mesoderm and the neuroectoderm as well as in the heart anlage. In particular with the monoclonal vimentin antiserum (Fig. 3C), a strong filamentous staining was found in the heart anlage. Note that there is also a strong positive staining reaction in the neuroectoderm overlying the foregut pocket "indicating coexpression with desmin in these cells. An intense reaction with the monoclonal antibody against cytokeratin 18 (CK18-2; Fig. 3D) was observed in the visceral endoderm. the foregut pocket and the visceral layer of the yolk sac at this stage. Except for the amnion epithelium, both ectoderm and neuroectoderm are still negative for the monoclonal and polyclonal keratin antibodies. However, mesodermal cells anterior to, and in, the heart anlage show a distinct positive reaction for keratin (Fig. 3D). Fibronectin showed the outlines of the basement membrane of the endoderm and the amnion epithelium, and was detected in the mesenchyme (Fig. 3E), as well as in the heart anlage. The endoderm and ectoderm are negative with this antiserum.

A slightly more advanced stage of heart development is shown in Fig. 4 in horizontal sections of a 8.5 d.p.c. mouse embryo. Cells of the presumptive endocard can now be seen between the endoderm and the developing myocard. Desmin is now exclusively observed in the developing heart (Fig. 4A), and could not be detected in the 
Table 1: Early expression of desmin and thin in the deweloping heart of mouse embryos.

\begin{tabular}{|c|c|c|c|c|c|}
\hline $\begin{array}{c}\text { Stages } \\
\text { of } \\
\text { cardiogenesis } \\
\text { (Thilen stage) }\end{array}$ & $\begin{array}{c}\text { Heart } \\
\text { rudiment } \\
8.25 \text { d.p.c. } \\
(12)\end{array}$ & $\begin{array}{c}\text { Hevet } \\
\text { rudingent } \\
8.5 \mathrm{~d} . \mathrm{p} . \mathrm{c} \\
(12)\end{array}$ & $\begin{array}{c}\text { Tubuldar } \\
\text { heart } \\
\text { 9.50.0.c } \\
\text { (1) }\end{array}$ & $\begin{array}{l}\text { Segmented } \\
\text { heart } \\
90 \text { d.p.c } \\
(14)\end{array}$ & $\begin{array}{c}\text { Segmented } \\
\text { heart } \\
9.50 .0 .2 \\
(14)\end{array}$ \\
\hline $\begin{array}{l}\text { desmin } \\
\text { expression } \\
\text { pattern }\end{array}$ & . & tilaments & t & $\stackrel{+}{+}$ & $\begin{array}{c}+ \\
\text { filaments and } \\
\text { striation }\end{array}$ \\
\hline $\begin{array}{c}\text { titin expression } \\
\text { partern }\end{array}$ & dots & $\stackrel{+}{\operatorname{dots}}$ & $\stackrel{+}{t}$ & $\begin{array}{l}\text { filaments and } \\
\text { silnation }\end{array}$ & $\begin{array}{c}+ \\
\text { filaments and } \\
\text { striation }\end{array}$ \\
\hline
\end{tabular}

neuroectoderm or any other region of the embryo. Titin coull be detected in the developing heart region, again in a punctate distribution (Fig. 4B). Vimentin was coexpressed with desmin in this region. and showed a strong filamentous immunofluorescence staining reaction in the myocardial cells (Fig. $4 \mathrm{C}$ ). but virtually no reaction in the endaderm. Underlying the endoderm, a few vimentin positive, but desmin negative, cells can be identified as the first endocardial cells. The neuroectoderm was still positive for vimentin (results not shown). Both the polyclonal and monoclonal keratin antisera stained cells of the heart anlage (Fig. 4D) as well as the overlying endoderm. while the neuroectoderm was negative.

\section{Tubular heart (Theiller stage 13)}

The next stage during heart development is the formation of a tubular heart in which the endocard is almost completely surrounded by myocard. Fig. 5 shows oblique sections through such a 8.5 d.p.c. embryonic heart. The formerly punctate staining pattern of titin antibodies is now replaced by a more filamentous staining pattern (Fig. 5B). The desminstaining reaction remains filamentous, comparable to the foregoing developmental stage (Fig. 5A). With the monoclonal and polyclonal vimentin antisera (Fig. 5C), a strong positive reaction was observed in the myocard and the endocard. Also with the keratin antisera we have found a positive reaction in the myocard of the tubular heart (result not shown:.

\section{Segmented heart (Theiler stage 14)}

At this stage, the anlagen of the different parts of the theart can be distinguished, i.e. the anlagen of the ventricular and the atrial compartments (Fig. 6). As in 8.5-day-old embryos, in 9.0 d.p.c. mouse embryos desmin expression seems to be restricted to the heart tissue, except for the myotomes (see below). The cells forming the myocardial wall are strongly positive with the polyclonal desmin antiserum (Fig. 6A), while the endocardial tissues are distinctively negative (asterisks in Fig. 6A). The monoclonal desmin antibody DE-B-5 showed only a partial reaction in the myocardial wall (result not shown). An extensive staining reaction was found in all cells of the myocardial wall with the titin antiserum (Fig. 6B), which was negative in the endocardial cells. In some of the myocardial cells, a transverse cross-striation was found (Fig. 7B) with this polyclonal titin antiserum, while there was no cross-striation found with the desmin (Fig. 7A) and the vimentin antibodies at this stage. The endocardial cells as well as the myocardial cells are specifically stained with the vimentin antiserum (Fig. 6C). Keratin expression seems to be 

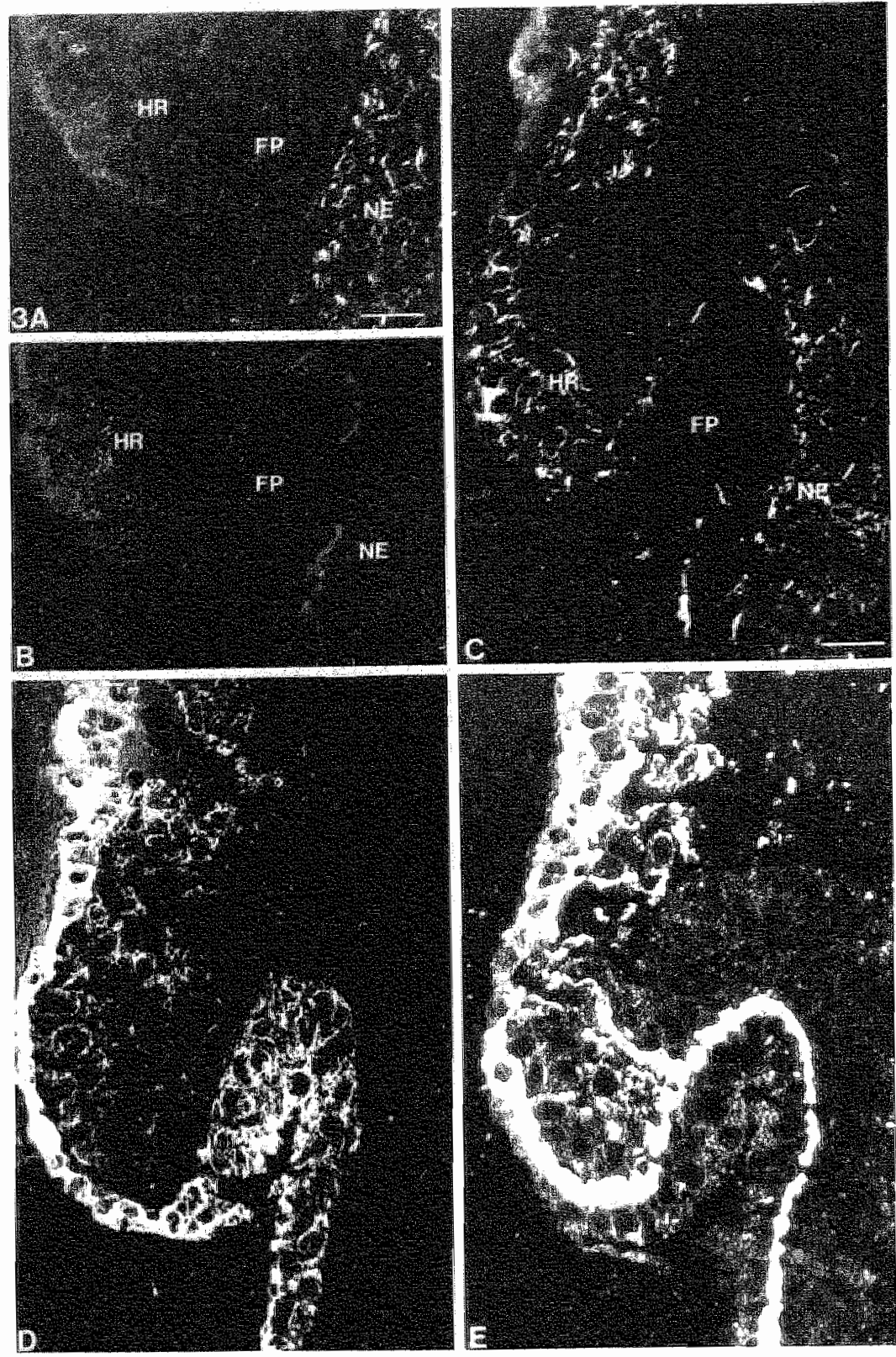

Figura 3: Immunofuoresconce micrographs of sagital frozen sections from 3.25 d.p.c. embryos of the mouse (Theitler stege 12 showing the heart rudiment IHRI, the foregut pocket (FP! and the neuroectoderm $(\mathbb{N} E$. The sections were incubated with: Ai the polychlonal antiserum against diesmin IpDesl; B) the polyclonal antiserum against titin (p Titin); Ch the monoclonal antiserum BV 118 against vimentin: Dy the monocional antiserum CK18-2 against cytokerath 18 and E) the polyclonal antiserum aganst fibrongetin |pFN|. Bars indicate $25 \mathrm{\mu m}$. 

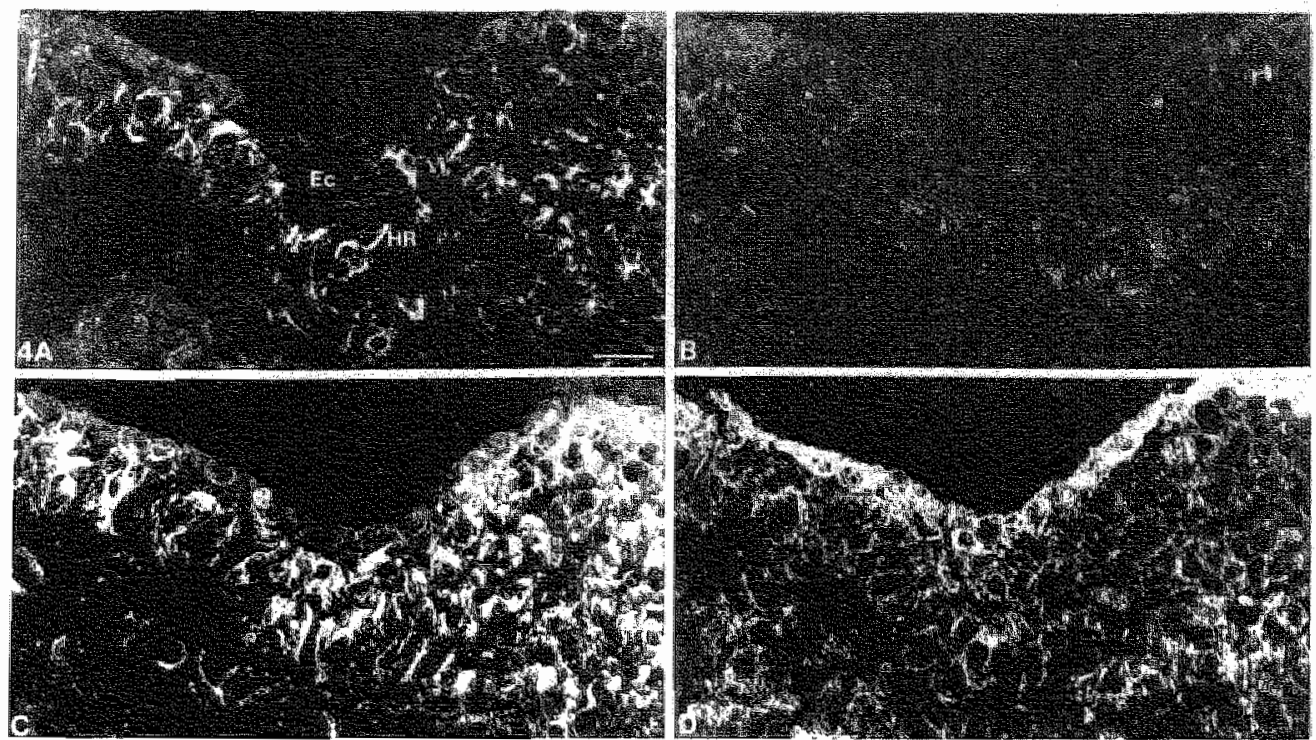

Figure 4: Immumofluorescence micrographs of horizontal sections from 8.5 d.p.c. mowse ambryos (Theiler stage 12), showing the heart rudiment (HR) and the endocard (EC). Sections were incubated with A) the polyclonal desmin antiserum (pDes); Bl the polyclonal titin antiserum (pTitim); C) the polyclonal vimentin antiserum (pVim), and D the polyclonal keratin antiserum IpKer). Bar indicates 25 mm.

drastically reduced in the heart anlage at this stage, although part of the cells still showed a weak punctate to fibrillar staining reaction with the monoclonal keratin antiserum CK 18 2 (Fig. 6D). Keratin-positive reactions of differentiating pericardial cells are also observed in the primitive oral epithelium, the thyroid anlage, the lateral plate of the mesoderm and the epidermal ectoderm with the monoclonal keratin antibody (CK18-2). During further differentiation of myocardial cells (e.g., in 9.5 d.p.c. embryos), coexpression of desmin and vimentin is evident. With both antibodies cross-striation can now be observed in individual cells at this stage (Fig. $8 \mathrm{~A}, \mathrm{~B}$ ) in addition to the cross-striations seen with the titin antibody. Keratin is still weakly expressed in some myocardial cells of 9.5 d.p.c. mouse embryos (results not shawn).

\section{Myotome}

In the mouse, somites begin to form at Theiler's stage 12 (Theiler, 1972). The somites at this stage are distinctly negative for desmin, titin and keratin, but positive for vimentin. Differentiation of the somite into dermatome, myotome and sclerotome starts at day 9.0 d.p.c. (Theiler stage 14: [7]) and this is accompanied by a positive staining reaction with the desmin and titin antisera in the most cranial myotomes of the embryo (Fig. 9). Desmin staining shows a filamentous staining pattern (Fig. 9A). while titin antibodies give rise to both a punctate and a filamentous staining pattern (Fig. 98). The vimentin antibodies stain all three somite-derived tissues (dematome, myotome and sclerotome: Fig. 9C). whereas these tissues are distinctly negative with all the keratin antibordies tested in this study (Fig. 9D). 

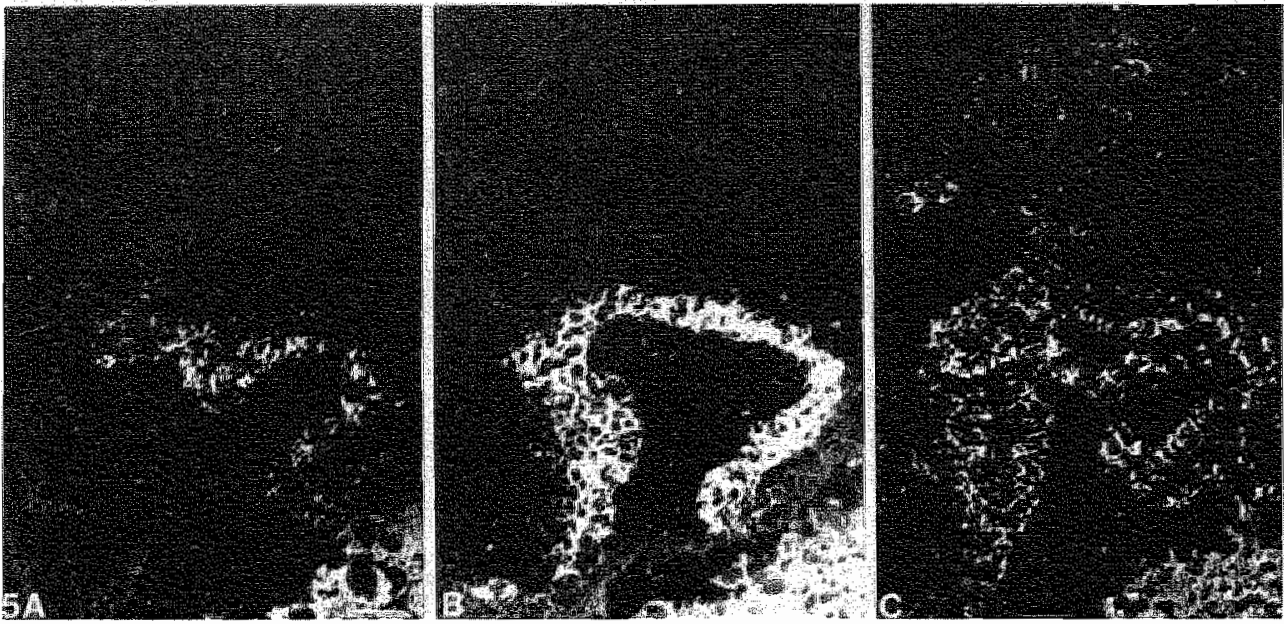

Figure 5 : immunofiuorescemce micrographs of firozen sections from 2.5 0.p.c. mouse embryos (Theiler stage 131 , showh the tubular heart. Sections were incubated with A) the monoclonal desmin antiserum (DE-B.5); B) the polyclonal titin antiserum (DTitin) and $C$ the manoclonal vimentin antiserum [BV11181. Bar indicates $50 \mathrm{~mm}$.

\section{DISCUSSION}

Desmin has been described to be a muscle-specific intermediate filament (IF) component in adult vertebrates 1141, while titin is a marker in adult striated muscle [50]. Both components may also serve as early markers of the anlagen of these tissues during embryogenesis $[43,44]$. In early stages of mammalian myofibrillogenesils, however, the intermediate filament protein (IFP) vimentin is expressed in the developing muscle cells, either without or in combination with desmin. Van Muijen et al. $[29]$ and Kuruc and Franke [22] have recently shown that human myocardial cells may even coexpress three different types of IFPs, i.e., keratins, vimentin and desmin [see also: 16].

The main studies, so far, on the expression of muscle-specific components during embryogenesis have concentrated on the chicken system Ifor review see: 8j. Recently, Tokuyasu and Maher [44] have described the distribution of titin in chicken cardiac premyolibril stages. Hill et al. [14] studied the interaction between titin and desmin in postmitotic mononucleated myoblast and concluded that the spatial organization of both components was not coupled. To a much lesser extent, such experiments have been performed in the mouse system [for an example see: 371 . Studies on the formation of If components during early mouse embryogenesis $[9,17,181$ have shown that no desmin expression can be detected before day 8.0 d.p.c.

In the present study, a punctate staining pattern of titin antibodies was found as the earliest sign of myogenic differentiation in the mouse heart at Theiler's stage 1218.25 d.p.c.l. Still at the same stage, only a few hours later, desmin expression was also initiated in the heart rudiment, showing a filamentous staining pattern, while titin still showed a punctate staining pattern. Again a few hours later when the heart changed to a tubular organization at Theiler's stage 13, the titin pattern changed to a fibrillar intracellular distribution with the desmin-staining pattern remaining the same as in the foregoing stage. Striation of titin became apparent in the segmented heart at 9.0 d.p.c. (Theiler stage 141. A few hours later at $9.5 \mathrm{~d}$.p.c., but still the same stage according to Theiler, cross-striation of desmin and vimentin was observed. Myogenesis in somites (i.e., in the myotome) was similarly accompanied by a punctate titin staining pattern (Theiler stage 


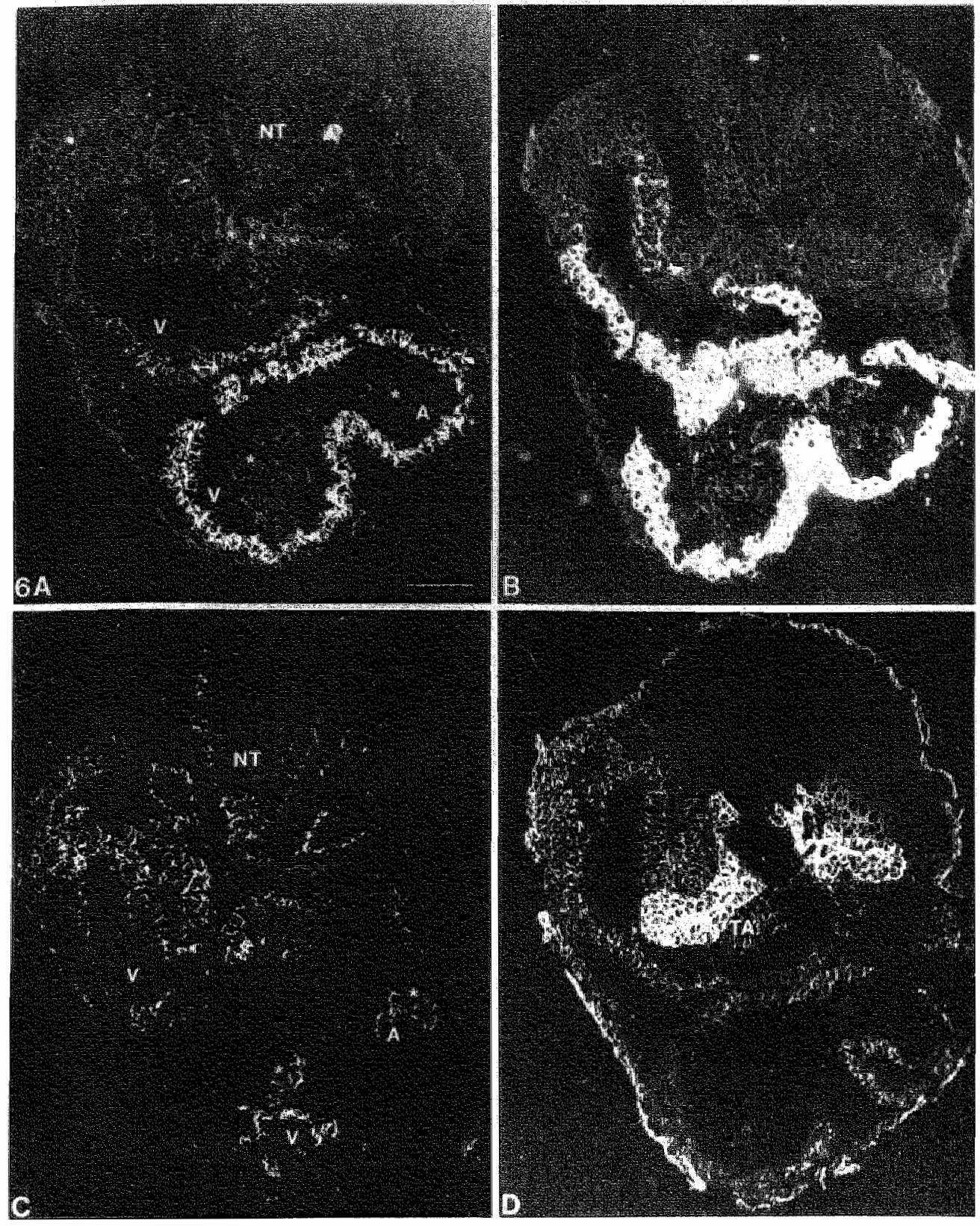

Figure 6: Immunofluorescence micrographs of frozen sections from 9.0 d.p.c. mouse embryos (Theilar stage 14), showing the neural tube (NT), thyroid anlage (TA), ventricular compartments (V). atial compartments [Al, and endocand (asterisksl. incubated with A) the polyclonal desmim antiserum (pDes?; B) the polyclonal titin antiserum (pTitin); C) the monoclonal vimentin antiserum $(\mathrm{BV} 1118)$; D/ the monoclonal keratin 18 antiserum (CK18-2). Bar indicates $100 \mu \mathrm{m}$. 

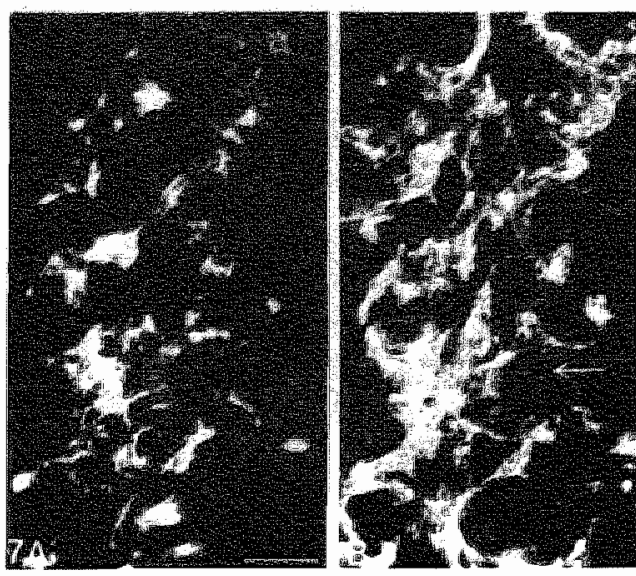

Figure 7: Immunofluorescence micrographs of a double staining of embryonic mouse myocardium Theiler stage 14.9.0 d.p.c.l, using All monochonal desmin antibody (DE-R- 11 ) and $B$ ) the polyclonal titin antibody (pTitin). Note the crossstriation in the titin-staining reaction (arrow in $\mathrm{B}$ ) and lack of obvious ciross-striation at corresponding sites in the desmin staining (A). Bar indicates $6 \mathrm{\mu m}$.

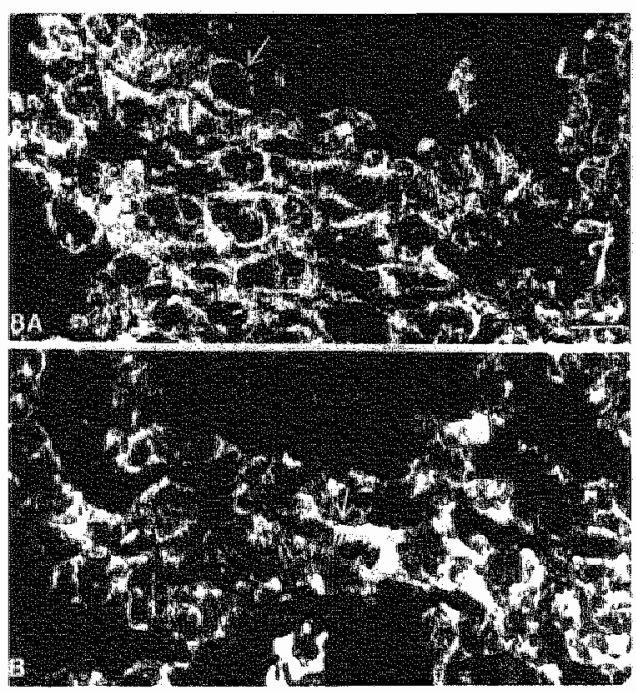

Figure 8: Immunofluorescence micrographs of frozen sections through the heart of a 9.5 d.p.c. mouse embryo tTheiler stage 141. Sections were hinculated with Al the polychonal desmin antiserum (pDes) and $B$ t the polyclonal vimentin antiserum (avim). Arrows show cross-striations in myocarcial calls. Bar indicates $9 \mu \mathrm{m}$.
14) which was followed by a change to a fibrillar-staining pattern. But here a delay between the appearance of titin and des. min could not be detected. possibly due to the speed of diffentiation in myotome cells. To our knowledge, this is the first description of the initiation of desmin expression in the vertebrate heart. Later stages of heart development have been described by Kuruc and Franke [22] in several species. Titin expression, however, has been described in the early stages of chick heart development by Tokuyasu et al. $[44]$, who also found a punctate staining pattern in the first stages. During further differentiation, this pattern changes into a fibrillar staining reaction.

In the underlying study, it became also evident that the first expression of mouse desmirn could be noted in the neuroectoderm of 8.25 d.p.c. mouse embryos. At 8.5 d.p.c. and later stages, the neuroectodermal layer was negative for desmin.

Coexpression of different types of IFP is a common feature in developing embryonic tissues, and to some extent also in certain adult organs 146-481. Recently, Van Muyen et al. [29] and Gown et al. [12] demonstrated a triple expression of keratins, vimentin and desmin in human fetal heart muscle cells. In mouse embryos, vimentin and keratin 18 were coexpressed in differentiating myocard together with titin at first. and later also with titin and desmin. The endocardial cells were always stained by the vimentin antibodies only. Desmin and keratin coexpression was also found to be a transient feature in theart development [22]. At 9.0 d.p.c., keratin reactivity in the myocard was drastically decreased. resulting in a negative reaction in 9.5 d.p.c. mouse embryos. However, at this stage, vimentin and desmin are still coexpressed and even colocalized as concluded from their cross-striated immunofluorescence pattern.

Although in vitro studies of myogenesis. show that desmin is a candidate for the first sign of myogenic differentiation, our studies clearly show that, in wivo, titin, and not desmin, is the first muscle-specific protein to be expressed in presumptive myogenic cells $[14,37]$. The titin antiserum used in this study showed a specific 

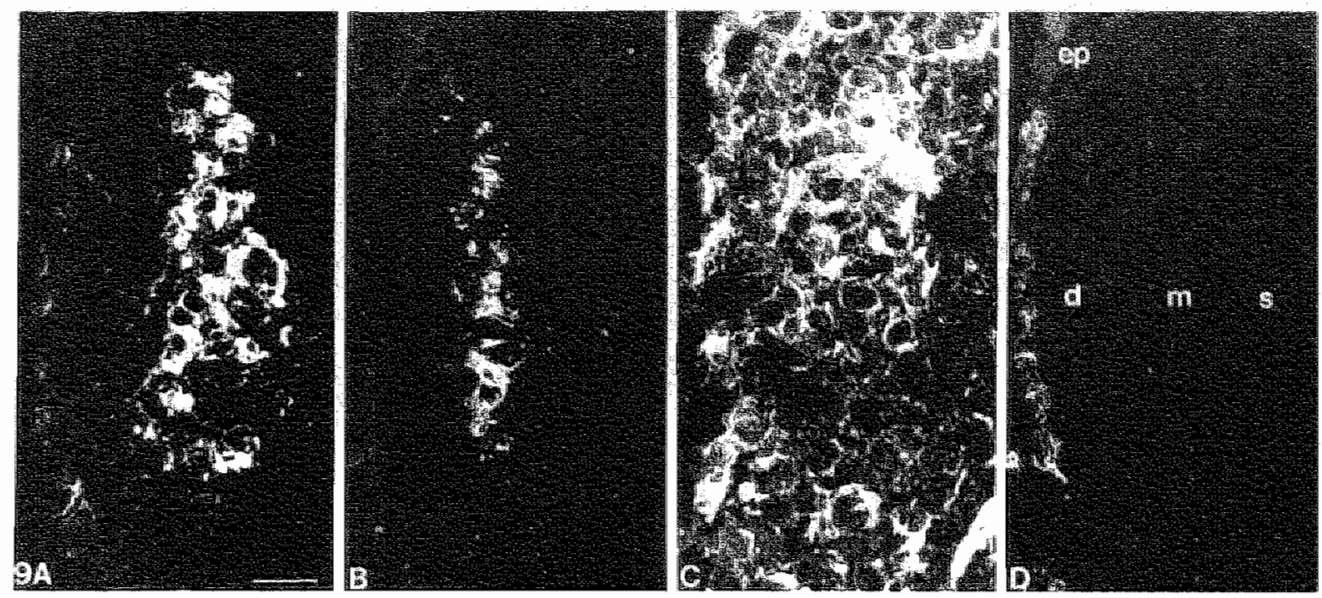

Figure 9: Immunofluorescence milcrographs of frozen sections of the myotome of $9.5 \mathrm{~d}$.p.c. mouse embryo (Theiler stage 14 . Sections were incubated with Al a polyclonal desimin antisarum (pDesl: B) a polyclonal titin antiserum (pTitin): C) a monoclonal vimentin antiserum (BVI 11B): keratin antiserum (pKer). lep: epidermal anlage; d: dermatome; m: myotome; s: sclerotomel. Bar indicattes $20 \mu \mathrm{m}$.

and exclusive immunoreactivity in the heart anlage of the mouse embryo before desmin expression could be detected in this region, at 8.25 d.p.c. (Theiler stage 12). The typi-cal punctate feature of this labelling pat-tern, which is comparable to that described by Tokuyasu and Maher [441 for early sta-ges of cardiac myotibrillogenesis in chick embryos, supports the assumption that, at this stage, the antiserum does indeed react with titin.

Unfortunately, no immunochemical proof can be obtained for this observation, since the concentration of the antigen in $8.25 \mathrm{~d} . \mathrm{p} . \mathrm{c}$. embryos is far too low to allow its detection in immunoblotting studies. At stage 8.5 d.p.c., titin is still present as spots in the developing myocard, while desmin can now clearly be detected and occurs in a filamentous fashion inside these premyocardial cells. Desmin and titin were coexpressed in 9.0 d.p.c. embryonic heart and myotome and showed similarly strong intensities in the immunofluorescence assays on frozen sections of this tissue. At this stage, however, a number of cells showed a striated titin staining pattern, while we could not observe such an organization for desmin. At 9.5 d.p.c., desmin, titin and vimentin were found to be colocalized in these crossistriations. Although it should be kept in mind that the studies so far have been performed in different systems, our observations that titin expression anticipates desmin synthesis seem in contrast with the in vitro findings of Hill et al. $[14]$. These authors showed desmin expression in presumptive replicating myoblasts present in embryonic chick skeletal muscle cultures. They could not detect titin until the postmitotic mononucleated myoblast stage and therefore suggested that this constituent is expressed later than desmin in the course of skeletal muscle myofibrillogenesis. Apparently, desmin and titin expression are differently coordinated in vivo and in vitro.

As far as the myotome is concerned, the present study shows allmost simultaneous appearance of titin and desmin in nascent myotome cells. This establishes titin as an early myogenic marker in the myotome in addition to desmin which was hitherto thought to be the earliest marker of myotomal differentiation $\llbracket 20,40,49 \|$. Furthermore, the characteristic developmentall change of the intracellular distribution of titin from punctate to fibrillar is seen in the myotome as well as in the heart, suggesting similar sequences of early myogenic differentiation operating both organs.

Acknowledgement: We are grateful to Annemiete van de Kemp for technical assistance 


\section{REFERENCES}

1. Bennet 6S, Tapscot SJ, Kleinbart FA. Antim PB. Hoirzer H. Difterent proteins alssociated with 10 -nanometer filoments in culturet chick neurons ard nonnetral colls. Science $212,507-569$, 1981.

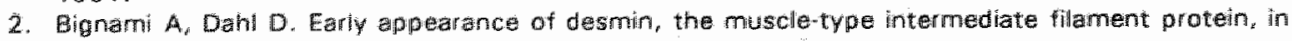
the rat tombryo. J. Histochern. Cytoctiem. $32,473-476,1984$.

3. Broers JLV, Carrey DN, Kiein Aot M. Schart G, Lane EB, Vooijs GP, Ramaekers FCS. Intermediate filament poteins in classic and variant types of small cell lung carcinoma cell lines: a biochemical and immunocherrical analysis using parel of monoclonal and polyclonal aritibodies. J. Cell Sci. $83,37.60,1986$.

4. Danto BI, Fischman DA. Immunocytochemical analysis of untemediate filaments in embryonic heart ceils with monocional antibodies to desmin. J. Ceil Bioll. 98, $2179-2191,1984$.

5. Debus $E$, Weber K, Osborn M. Monoclonal antibodies specific for glial fibrilary acidic (GFA) protein and for each of the neurofilament triplet polypeptides. Differentiation $25,193-203,1983$.

6. Dabus $E_{\text {, Weber }} K$, Osborn, M. Monoclonal antibodies to desmin, the muscle specific intermediate flament. EMBO J.2, 2305-23:2, 1983.

7. Ede DA, EH-Gadi ADA. Genetic modifications of developmental acts in chick and mouse somite development. In: Somites in Developing Embryos. (eds. Bellairs R, Ede DA, Lash JWh Plenum Press, New York, pp. 209-224, 1986.

8. Fischman DA. Myotibrillogenesis and the morphogenesis of skeletal muscie. In: Myohog: Basic and Clinical. (ads. Engel AG, Banker BO) McGraw-Hit, New York, pp. 5.30, 1986.

9. Franke WW, Grund $C_{\text {. Kuhn }} C_{\text {. Jackson }}$ BW, llimensee K. Formation of cycoskeletal elements during mouse embryogenesis. ll1. Primary mesenchymall cells and the first appearance of vimentin filaments. Differentiation $23,43-59,1982$.

10. Franke WW, Moll R. Cytoskeletal components of Iymphoid argans. 1. Synthesis of cytokeratins 8 and 18 and desmin in subpopulations of extrafollicular reticulum cells of human lymph nodes, tonisils and spleen. Differentiation 36, 145-163, 1987.

11. Gassner D. Myofibrillar interaction of blot immunoatfinity-purified antbodies against titin as studied by indirect immunotluorescence and immunogold staining. Eur. N. Cell Biol. 40, 176-184, 1986.

12. Gown AM, Boyd HC, Chang Y, Ferguson M, Reichler B and Tippens D. Smooth muscle celis can express cytokeratins of "simple" epithelium. Imimunocytochemical and biochemical studies in witro and in wivo. Am. J. Patti. 132, $223-232,1988$.

13. Heuijerjans J, Pieper FR, Ramaekers FCS, Timmermans LJM, Kuijpers HJH, Bloemendal H, Venrooil WJ van. Association of mANA and elf. 20 with the cytoskelleton in cells lacking vimentin. Expl. Celll Res. 181, 317-330, 1989.

14. Hill CS, Duran $S$, Zhongxiang $L$, Weber K, Holtzer $H$. Titin and myosin, but not desmin, are linked during myofibrilogenesis in postmitotic mononucleated myoblasts. J, Cell Biol. 103, 2185-2196. 1986.

15. Moltzer H, Bennett GS, Tapscott SJ, Croop JM. Toyama $Y$. Intermediate-sized filaments: changes in synthesis and distrbutions in cells of myogenic and neurogenic lineages. Cold Spring Harbor Symp. Quant, Biol. $46,347-326,1982$

16. Hutfeldt $H S$, Brandtzaeg $P$. Warious keratin antibodies produce immunohistochemical staining af human myocardium and myometrum. Histochernistry $83,381-389,1985$.

17. Jackson BW, Grund C, Schmïd E. Bürk K, Frarke WW, Illmensee K. Formation of cytosikeletal elements durng mouse embryogenesis. I. Intermediate filaments of the cytokeratin type and desmosomes in premplantation embryos. Differentiation 17, 161-179, 1980.

18. Jackson $B W$, Grund $C$. Winter $S$, Franke WW, illmensee K. Formation of cytasikeletal elements. during mouse ambryogenesis. Hi. Epithelial differentation and intermediate-sized filaments in early postimplantation embryos. Differentiation $20,203 \cdot 216,1981$.

19. Johnson GD, Davidson AS. Fading of immunofluorescence during microscopy. A study of the phenomenon and its remedy. J. Immun. Methods 55, 231-242, 1982.

20. Kaehn $K$, Jacob $H J$. Cheist $B$, Hinrichsen $K$. Poelmann RE. The onset of myotome formation in the chick. Anat. Embryol. 177, 191-201, 1988.

21. Kaufman $M H$, Navaratnam $V$. Early differentiation of the heart in mouse embryos. J. Anat. 133, $235-246,1984$.

22. Kuruc $K$, Franke WW. Transient coexpression of desmin and cytokeratins 8 and 18 in developing myocardial cells of some vertebrate species. Differ entiation $38,177-193,1988$.

23. Latammli UK. Cleavage of structural proteins during the assembly of the head of bacteriophage T4. Nature $227,680-685,1970$ 
24. Lazarides E, Granger BL, O'Connor CM, Breckler J, Price M, Danto Sl. Desmin- and wimentincontaning filaments and their role in the assemby of the $Z$-disc in muste cells. Cold Spring Harbor Symp. Quant. Biol. 46, 351-378. 1982.

25. Maruyame K. Connectin, an elastic rlamentous protein of striated muscle. Int. Mev. Cytol. 104. $81-114,1986$.

26. Maruwama $K_{n}$ Natori $A$, Nonomura $Y$. New elastic proten from muscle. Nature $262,58-60,1976$.

27. Molengraft $F$ van de, Ramaekers $F$, Jap $P$, Voojs $P$, Mungyer $C$. Changing intermedtate sized Hitment patterns in metastatic hepatocellular cairchoma cels of the quinea pig. Virchows Arch. B $51,285-301,1986$.

28. Moll R, Franke WW, Schiller DL, Geiger $B$, Krepler R. The catalog of human cytokeratins: patterns of expression in normal epithelia, tumors and cultured cells. Cell $31,11-24,1982$.

29. Mulien GNP van, Ruiter DJ, Warnaar SO. Coexpression of intermediate filament polypeptides in human fetal and adult tissues. Lab. Invest. 57, 359-369, 1987.

30. OFarrell $\mathrm{PH}_{\text {n }}$ High resolution twowdimensional electrophoresis of pratains. J. Bial. Ghem. 230, $4007-4021,1975$.

31. Osborn M, Ludwig-Fest M, Weber K, Bignami D, Dahl D, Bayrouther K. Expression of glial and wimentin type intermediate filaments in cultures derived from human glial material. Differentiation $19,16 \rrbracket-167,1981$.

32. Pieper FR, Schaart G, Krimpentort PJ, Henderik JB, Moshage HJ, Ramaekers FCS, Berns A, Bloemendal $H$. Transgenic expression of the muscle-specific intermediate filament protein dasmim in monmuscle cells. J. Cell Biol. 108, 1009-1024, 1989.

33. Qunian RA, Schiller DL, Hatzfeld M, Achtstätter T, Moll R, Jorcano UL, Magin TM, Franke WW. Patterns of expression ond organization of cytokeratin intermediate filaments. Ann. NY Acad. Sel. $455,282-306,1985$.

34. Ramaekers FCS, Huijsmans A, Schaart G, Moesker O, Vooijs GP. Tissue distribution of keratin 7 as manitored by a monoclonal antibady. Expl. Cell Res. 170, 235-249, 1987.

35. Ramaekers FCS, Moesker $D$. Huijsmans A, Schaart $G$, Westerhof $G$, Wagienaar SjSc, Herman $C$ J Woolis GP. Intermediate filament proteins in the study of tumor heterogeneity: an in-depth study on tumors of the urinary and respiratory tracts. Ann. NY. Acad. Sci. 455,614-634, 1985.

36. Ramaekers FCS, Puts JJG, Maesker O, Kant A. Huijsmans A, Haag D, Jap PHik, Herman Cu Voois GP. Arrtbodies to intermediate filament proteins in the immunohistochemical identification of thuman tumours: an overview. Histochemical $\rfloor .15,691-713,1983$.

37. Sassoon DA, Garner 1, Buckingham M. Transcripts of a-cardiac and a-skeletal actins are eariy markers for myogenesis in the mouse embryo. Dewelopment $104,155-164,1988$.

38. Schnitzer J, Franke WW, Schachner M. Immunocytochemical demonstration of vimentin in astrocytes and ependymal cells of developing and adult mouse nervous system. J. Cell Biol. 90 , $435-447,1981$

39. Shaw $G$, Osborn $M$, Weber $K$. Reactivity of a panel of neurofilament antibodies on phosphorylated and dephosphorylated neurofilaments. Eur. J. Cell Biol, 42, 1-9, 1986.

40. Solursh M, Meier S. The distifibution of somitederived myogenic cells durng early development in the wing bud. In: Somites in Developing Embryos. (eds. Belliairs R, Ede DA, Lash JW' Plenum Press, New York, pp. 261-275, 1986.

4. Tapscott SJ, Bennet GS, Toyama $Y$, Kleinbart F, Holtzer H. Intermediate filament proteing in the developing thick spinal chord. Dew. Biol. 86, 40,54, 1981.

42. Theiler $K$. The House Mouse. Development and Norma Stages from Fenthation to a Weeks of Age. First edition, Springer-Verlag. Berlin, 1972.

43. Tokuyasu KT, Maher PA, Singer S. Distributions of vimentin and desimin in developing chick myotubes in vivo. ل. Cell Biol. 98, 1961-1972, 1984.

44. Tokuyasu KT, Maher PA. Immunocytochemical studies of cardiac myofibrillogenesis in early chick embryos. 1. Presence of immunofluorescent titin spots in prempofibril stages. A. Call Biol. 105. $2781-2793,1987$

45. Towbin $H_{*}$ Staehelin T, Gordon J. Electrophoretic transter of proteins from polyacrylamicle gels to nitrocellulose sheets: procedure and some applications. Proc. Natl. Aciad. Sci. USA 76, 4350. 4354,1979

46. Traub P. Intermediate Filaments. A. Review. Springer-Verlag. Berlin, 1985.

47. Wiebahn C. Lane EB, Ramaekers FCS. The mesonephric Wolffian and paramesonephric (Müllerian ducts of golden hamster express different intermediate filament proteins during development. Differentiation $34,175 \cdot 188,1987$.

48. Viebahn C, Lane EB, Ramaekers FCS. Keratin and vimentin expression in garly organogenesis of the rabbit embryo. Cell Tissue Res. 253,553-562, 1988.

49. Webahn C. Das Muster der Intermediaffilamentproteine wathrend der Histogenese der Somiter 
beim Kantinchen. Verth. Hat. Ges. 93,1989 (nn press),

50. Warn $K$, MeClure $J$, Tu A. Tin: Mator myotbrilar components of strated muscle. Proc. Natl. Ascad. Sti. USA 76, 3698-3702, 1979. 


\title{
CHAPTER 2
}

BABY HAMSTER KIDNEY (BHK-21/C 13) CELLS CAN EXPRESS STRIATED MUSCLE TYPE PROTEINS

\author{
G. SCHAART, F.R. PIEPER, H.J.H. KUIJPERS \\ H. BLOEMENDAL and F.C.S. RAMAEKERS
}

Differentiation $46,105-115,1991$ 
When Baby Hamster Kidney (BHK-21/C13) cell lines are subjected to low-serum medium, cell morphology changes from polygonal to elongated, while occasionally fusion of cells is also observed. BHK-21 cells initially growing in Eagle's modified minimum essential medium (EMEM) containing $10 \%$ newborn bovine serum, were induced to differentiate by changing the culture medium after the cells had grown to confluency. After this point the cells were grown in a low-serum medium (EMEM with $2 \%$ normal horse seruml, for at least 4 days. The expression of different muscle-specific proteins Idesmin, titin and skeletal muscle myosin and of tropomyosins was studied in both polygonal and clongated BHK-21 cells using the indirect immunoflucrescence assay, two-dimensional (2D)-gel electrophoresis and limmunoblotting.

Filamentous staining was found with the desmin antisera in the polygonal cells and at all stages of BHK cell elongation. While no reaction was seen with the titin and myosin antibodies in the polygonal cells, a punctate staining reaction for titin was detected 2 days after medium-change. although the cells had not yet elongated. After 4 days titin was found in a striated pattern. Filamentous staining was seen with the skeletal musclespecific myosin antibody at this stage. Confirmatory results were obtained from immunoblotting assays and 2D-gel electrophoresis of cytoskeletal preparations from undifferentiated and differentiated BHK cells. These latter experiments showed the initation of tropomyosin expression only in the differentiated cells. The positive staining with antibodies to skeletal muscle myosin and titin indicates a striated-muscle nature of the lelongated) BHK-21/C13 cells.

\section{INTRODUCTION}

During in vivo and in vitro myogenesis of smooth, skeletal and cardiac muscle cells, characteristic muscle-specific markers appear at different stages of differentiation 13,10 , $12,23,25,44,58$ ). The muscle-specific intermediate filament protein (IFP) desmin has so far been found in smooth, skeletal and cardiac muscle [7, 30], although some exceptions to this rule have been described [14,36]. Titin, a high molecular weight protein, is expressed only in striated muscle cell types, both in viwo and in vitro 110,22 , $25,35,57,58]$. It is one of the earliest markers of myofibrillogenesis $[12,44,53]$. Myosin is expressed during a later stage of muscle development, while different isoforms of myosin have been demonstrated in embryonic and adult striated muscles in both birds and mammals $[3,18,34]$. Titin is first expressed in a punctate pattern $[6,44,53]$, and in later stages of muscle cell development it shows a striated pattern in both skeletal and cardiac muscle $[12,25,44]$. Upon progression of differentiation or development, desmin and titin are coexpressed. whille even later skeletal muscle actin and skeletal muscle myosin heavy chains become detectable in the striated myocytes.

The expression of IFP in BHK-21 cells has been studied by several investigators 12,13 , $15,40,47-50,561$. The two major cytoplasmic IF polypeptides that can be isolated from BHK-21 cells are characterized as desmin and vimentin. So far, the expression of other muscle-specific constituents such as myosin, actin and titin in BHK-21 cells has been studied only sporadically $18,26,27]$.

The detection of desmin in these cells has raised questions concerning their nature [1, 9 , 52.l and suggests a smooth muscle cell-type of origin. In this study we have used antibodies specific for striated-muscle constituents (titin and skeletal muscle myosin) in combination with more general muscle cell markers (desmin, actin, vimentin) in immunofluorescence and in immunoblotting assays of BHK-21 cells. When these cells were induced to elongate and fuse upon culturing in low-serum medium, profound changes in the expression and organization of these proteins were observed. 


\section{BHK-21/C13 cell cultures}

The establishment and characteristics of the BHK-21/C13 cell line have been diescribed previously $[8,11,13,26,27,30,32,33,40,49,511$. BHK-21 cell lines were obtained from three different sources i.e., from Flow Laboratories (Irvine, UK), the Department of Pathology of the University Hospital Nijmegen and the Department of Biochemistiry of the University of Nijmegen. These three cell lines were independently cultured in Eagle's modified minimum essential medium (EMEM; Flow Laboratories, Irvine, UK) containing $10 \%$ newborn calf serum (Gibco, Paisley, UK), $2 \mathrm{mM}$ L-glutamine (Flow Laboratories) and antibiotics (penicillin and streptomycin). The cells were grown on glass coverslips (Menzel Gläser, FRG) in petri dishes ( $O=100 \mathrm{~mm}$; Costar, Cambridge, UK) or six-well plates (Costar) in a humidified incubator at $5 \% \mathrm{CO}_{2}$ and $37^{\circ} \mathrm{C}$.

Elongation and partial fusion of the cells was initiated by changing the culture medium after the cells had grown to almost complete confluency. At this point the medium was replaced by a low-serum medium i.e. EMEM containing $2 \%$ normal horse serum (Flow Laboratories) and the same additions as described above. After "differentiation", the BHK21 cells were analyzed at different times following the change of medium. The glass coverslips were washed in phosphate-buffered saline (PBS: $137 \mathrm{mM}$ sodium chloride (Merck, Darmstadt, FRG), $13 \mathrm{mM}$ di-sodium hydrogen phosphate dihydrate $\left(\mathrm{Na}_{2} \mathrm{HPO}_{4} \cdot 2 \mathrm{H}_{2} \mathrm{O}\right.$; Merck), $3 \mathrm{mM}$ potassium dihydrogen phosphate $\left(\mathrm{KH}_{2} \mathrm{PO}_{4}\right.$; Merck), pH 7.4) [24], the cells were fixed by dipping the gllass coverslips in cold methanol (Merck; $-20^{\circ} \mathrm{C}$ ) for $3 \mathrm{sec}$ followed by acetone (Merck) fixation (dipping, $-20^{\circ} \mathrm{C}$ ), and air-dried at room temperature for $10 \mathrm{~min}$. They were stored at $-30^{\circ} \mathrm{C}$ until use.

\section{Metabolic labelling of $\mathrm{BHK}-21 / \mathrm{C} 13$ cell cultures}

Both polygonal and elongated BHK-21/C 13 cells, growing in plastic culture flasks (Costar) were washed with PBS and cultured for $1 \mathrm{~h}$ in methionine-depleted medium (Eagle's modified minimum essential medium, Flow Laboratories) supplemented with glutamine and antibiotics as above. Immediately thereafter the medium was supplemented with

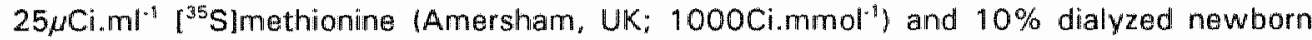
calf serum for the polygonal cells and $2 \%$ dialyzed normal horse serum for the elongated cells. Cells were labelled for $16 \mathrm{~h}$ at $37^{\circ} \mathrm{C}$.

\section{Indirect immunofluorescence assays}

The BHK-21/C13 cells on glass coverslips were fixed as described above. Five micrometer thick cryostat sections, obtained from fresh frozen hamster tissues were fixed for $5 \mathrm{~min}$ in methanol at $-20^{\circ} \mathrm{C}$ and for $1 \mathrm{~min}$ in acetone at $-20^{\circ} \mathrm{C}$ and air-dried. Alternatively, the sections were treated for $5 \mathrm{~min}$ with $0.5 \%$ Triton $X-100$ (BDH Chemicals Ltd., Poole, UK) in PBS, followed by a PBS washing step.

The sections and BHK-21 cells were incubated with the primary antibody for 30 min at room temperature. After washing with PBS, they were incubated for $30 \mathrm{~min}$ at room temperature with the appropriate fluorescein isothiocyanate- (FITC) or tetramethylrhodamine isothiocyanate- (TRITC) conjugated secondary antibody (rabbit anti-mouse IgG FITC, rabbit anti-mouse IgM FITC, goat anti-rabbit Ig FITC, all from Nordic Immunologv, Tilburg. The Netherlands, and swine anti-rabbit $1 \mathrm{~g}$ TRITC from DAKOpatts, Glostrup, Denmarkl, and washed again with PBS. Sections and BHK-21 cells were mounted in Fluorstab (Euro-Diagnostics BV, Apeldoorn. The Nethertands). Slides were examined with a Leitz Microscope EB2O equipped with epifluorescent illumination. Pictures were taken 
on a Trrax-film (Kodak Ltd. Hemel Hempstead, UK) with an automatic camera using an ASA setting of 400 .

\section{Cell fractionation and gel electrophoresis}

BHK-21/C13 cells were harvested from $150 \mathrm{~cm}^{2}$ culture flasks by scraping the cells from the bottom of the flask with a rubber policeman. The cells were washed with PBS containing $0.4 \mathrm{mM}$ phenylmethylsulfonyl fluoride (PMSF; Merck). centrifuged for $10 \mathrm{~min}$ at $3000 \times g$, and extracted in $0.5 \%$ Triton $X-100,5 \mathrm{mM}$ EDTA (Merck), 0.4 mM PMSF and PBS, $\mathrm{pH} 7.4$, essentially as described [4]. After centrifugation ffor $10 \mathrm{~min}$ at $0^{\circ} \mathrm{C}$. $3000 \times \mathrm{gl}$, and washing with PBS, the cytoskeletal preparation was dissolved by boiling for 4 min in sample buffer [29], containing $2.3 \%$ sodium dodecylsulphate (SDS; BDH Chemicals Ltd. I.

One-dimensional gel electrophoresis (Mini-Protean II Electrophoresis Cell, Bio-Rad Laboratories, Richmond. CA, USA) was performed in $7.5 \%$ polyacrylamide (Bio-Rad Laboratories) slab gels containing $0.1 \%$ SDS 1291 . The gels were stained with Coomassie Brilliant Blue R250 (Gurr, Hopkins and Williams, Chadwell Heath, Essex, UK) for 30 min at $50^{\circ} \mathrm{C}$ to compare the amounts of protein per lane $[4]$.

For 2D-gel electrophoresis, isoelectric focussing conditions according to O'Farrell [37] were used, applying a mixture of $\mathrm{pH} 3-10$ and $\mathrm{pH} \mathrm{4-6}$ ampholines (Biolyte $3 / 10$ and Biolyte 4/6, Bio-Rad Laboratories). Electrophoresis was performed for 7,200 Vh. For the second dimension $12 \%$ polyacrylamide SDS-gels were used (Protean 11 Electrophoresis Cell, Bio-Rad Laboratories).

\section{Immunoblotting}

For immunoblotting experiments, the electrophoretically separated polypeptides were transferred (Mini Trans-Blot Electrophoretic Transfer Cell, Bio-Rad Laboratories) to a nitrocellulose sheet. (Schleicher and Schuell Membrane Filters BA85, Dassel, FRG) by blotting for $1 \mathrm{~h}$ at $100 \mathrm{~V}$ in a cold $\left(4^{\circ} \mathrm{C}\right.$ ) buffer containing $25 \mathrm{mM}$ Tris (Merck), $192 \mathrm{mM}$ glycine (Merck), $0.02 \%$ SDS (BDH Chemicals Ltd.) and $20 \%$ methanol [55]. The blots were incubated for $60 \mathrm{~min}$ with PBS containing $0.05 \%$ Tween 20 (Sigma Chemical Company, St.Louis, USA). All reagents were diluted in this Tween20/PBS buffer, which was also used for the washing steps. After overnight incubation with the primary antibodies 9D10 (dilution 1:10), RD301 (dilution 1:5) and MF20 (dilution 1:2), the blots were washed three times for $10 \mathrm{~min}$ and incubated for $1 \mathrm{~h}$ with horseradish peroxidase. conjugated rabbit anti-mouse Ig (DAKOpatts) diluted 1:400. The blots were wasthed again three times for $10 \mathrm{~min}$ in $0.05 \%$ Tween20/PBS, once in PBS alone and stained with 4 chloro-1-naphtol (Merck) and $0.12 \%$ hydrogen peroxide (Merck). After staining the blots were rinsed for 5 min with tap water.

\section{Antibodies and reagents}

The following antibodies were used in this study (summarized in Table 1):

1. A polyclonal antibody (pDes) to chicken gizzard desmin $[43,44]$.

2. A mouse monoclonal antiserum (RD301) to desmin $[39,44]$.

3. An affinity-purified polyclonal rabbit antiserum ( $p$ Vim) to bovine lens vimentin [42].

4. The mouse monoclonal antibody RV203. This antibody, specific for vimentin, was obtained after a fusion of splenic lymphocytes from a female Balb/C mouse with mouse myeloma Sp2/O-Ag14 cells in polyethyleneglycol-4000 (Merck). The mouse had been immunized twice intraperitoneally and thereafter three times intravenously 
with approximately $75 \mu \mathrm{g}$ of purified bovine lens vimentin per immunization. Growth conditions, cloning and testing procedures were essentially as described before for other antibodies 1411. This antiserum of the IgG1 subclass, tested in indirect immunofluorescence and immunoperoxidase assays, stains tissues of mesenchymal origin and gives a filamentous staining pattern in cultured cells such as BHK-21, Hela and WiDr. No reaction was found in most epithelial tissues, and in cultured cells such as T24, RT4 and MCF7, known to lack vimentin IFP [21]. In immunoblotting assays of cytoskeletal extracts of bovine lens. BHK-21/C13 and HeLa cells this manoclonal antibody reacts exclusively with a $57 \mathrm{kDa}$ protein, which can be characterized as vimentin in 20 -immunoblots.

5. An affinity-purified polyclonal rabbit antiserum to titin, (kind gift from Dr. D. Gassner, University of Bonn, FRGI, was used in a 1:25 dilution [17,441. When tested in the indirect immunofluorescence assay, this antiserum reacted specifically with striated (skeletal and cardiac) muscle cells. No reaction was found in smooth muscle cells or in non-muscle cells.

6. A mouse monocional antiserum to titin $(9010) \llbracket 19,20,57\rceil$.

7. A mouse monoclonal antiserum to striated muscle myosin (MF20). This antiserum reacts with all sarcomeric myosins (adult and embryonic) [3].

Monoclonal antibodies 9D10 and MF20 were obtained from the Developmental Studies Hybridoma Bank, maintained by the Department of Pharmacology and Molecular Sciences, Johns Hopkins University School of Medicine, Baltimore, MD, USA, and the Department of Biology, University of lowa, lowa City, IA, USA, under contract NO1-HD6-2915 from NICHD.

8. A mouse monoclonal antibody sm-1 (BioMakor, Rehovot, Israel), recognizing exclusively a-smooth muscle actin $[45,59]$.

9. A mouse monoclonal antibody $\mathrm{sr}-1$, recognizing exclusively striated muscle a-actin [46], which was a kind gift of Dr. G. Gabbiani (Geneva, Switzerland).

10. A mouse monoclonal antibody RAc1, directed against actin, was obtained after fusion of spleen cells from a female Balb/C mouse immunized with a mixture of cytoskeletal preparations (extractions in PBS containing $0.5 \%$ Triton $X-100$ ) of the T24 and A431 cell lines. This monoclonal antibody of the $\mathrm{lgM}$ subclass was characterized by immunofluorescence assays $[21,281$ and reacts with myoepithelium of human tissues, with human and hamster skeletal muscle cells and with stress fibers in cultured human cells [21].

Other reagents used in this study were Rhodamine-labelled phalloidin (Molecular Probes, Inc., Junction City, USA) which stains F-actin. The $3.3 \mu \mathrm{M}$ stock solution of Rhodaminephalloidin was diluted $1: 25$ in PBS. The nuclei were stained with Hoechst 33258 , at a final concentration of $0.1 \mu \mathrm{g} \cdot \mathrm{ml}^{-1}$ in $22 \mathrm{mM}$ citric acid $\left(\mathrm{C}_{63} \mathrm{H}_{8} \mathrm{O}_{2} . \mathrm{H}_{2} \mathrm{O}\right.$; Merck) and $56 \mathrm{mM}$ di-sodium hydrogen phosphate ( $\mathrm{Na}_{2} \mathrm{HPO}_{4}$ : Merck).

\section{RESULTS}

\section{Antibody reactivity patterns in harnster tissues}

Before using the antisera on BHK-21/C13 cells, their specificity in hamster tissues, including heart muscle, tongue and skeletal muscle from the hind limb was tested (see Table 1).

The polyclonal and monoclonal antibodies to desmim showed a positive staining reaction in hamster smooth muscle, skeletal muscle and cardiac muscle IFig. 1A, C. Fi. Striation with these antisera was seen in skeletal and cardiac muscle. Also with the polyclonal titin antibody a striated pattern was obtained in cardiac muscle and skeletal muscle (Fig. 1E, G. H). The monoclonal antibody to titin (9D10) showed a striated pattern only in the hamster skeletal muscle (Fig. 1B, D), while no reaction was found in hamster heart tissue 
Table 1: Specticity of the monoclonal and polvelonal antibodies, and of the thodamine labelled phalloum reagent used in this study and their reaction patten in hamster muscle and nonmuscle cellis.

\begin{tabular}{|c|c|c|c|c|c|c|c|}
\hline \multirow{2}{*}{$\begin{array}{l}\text { Antibooy/ } \\
\text { ragamem }\end{array}$} & \multirow{2}{*}{$\begin{array}{l}\text { spacies } \\
\text { Ho } \\
\text { subclass }\end{array}$} & \multirow[t]{2}{*}{ antigen } & \multicolumn{3}{|c|}{ muscle cell trpe } & \multirow{2}{*}{$\begin{array}{c}\text { connec- } \\
\text { tiwe } \\
\text { rissue }\end{array}$} & \multirow[t]{2}{*}{ Ret. } \\
\hline & & & smooth & skeletal & cardiac & & \\
\hline PDes: & $\begin{array}{l}\text { sabit } \\
\text { serum }\end{array}$ & desmin & + & + & + & - & 43,44 \\
\hline AD 301 & $\begin{array}{l}\text { mouse } \\
\operatorname{lgc2b}\end{array}$ & desmin & - & + & $*$ & - & 38 \\
\hline pvirn & $\begin{array}{l}\text { rabibit } \\
\text { serumn }\end{array}$ & vimentin & $=$ & 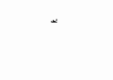 & 。 & + & 41 \\
\hline $\mathrm{PV} 203$ & $\begin{array}{l}\text { mouse } \\
\text { IgGi }\end{array}$ & wimentin & - & - & - & + & $\begin{array}{l}\text { this } \\
\text { paper }\end{array}$ \\
\hline ptitin & $\begin{array}{l}\text { labbitt } \\
\text { serum }\end{array}$ & titin & - & + & + & * & 17,44 \\
\hline 9010 & $\begin{array}{l}\text { mousie } \\
\text { loM }\end{array}$ & tition & - & * & - & - & $\begin{array}{c}19.20 \\
57\end{array}$ \\
\hline MF2O & $\begin{array}{l}\text { mouge } \\
\lg 2 \mathrm{~b}\end{array}$ & $\begin{array}{l}\text { striated } \\
\text { muscle } \\
\text { myosin? }\end{array}$ & - & + & + & 。 & 3 \\
\hline$s m \cdot 1$ & $\begin{array}{l}\text { mouse } \\
\lg 222\end{array}$ & $\begin{array}{l}\text { smooth } \\
\text { muscle } \\
\text { actin }\end{array}$ & + & - & - & - & 45,59 \\
\hline$s r-1$ & $\begin{array}{l}\text { mouse } \\
\lg M\end{array}$ & $\begin{array}{l}\text { striated } \\
\text { muscile } \\
\text { actin }\end{array}$ & - & - & - & $\sim$ & 46 \\
\hline RAC 1 & $\begin{array}{l}\text { mouse } \\
\operatorname{lgM}\end{array}$ & actin & 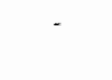 & t & + & - & 21,28 \\
\hline $\begin{array}{l}\text { Rhodamine } \\
\text { phalloidin }\end{array}$ & & & + & + & + & - & 24 \\
\hline
\end{tabular}

- Diffuse stainting pattern

(Fig. 11). Neither titin antisera stained smooth muscle cells. (Fig. 1B). The monoclonal antibody sm-1 to smooth muscle actin, showed a strong positive reaction in the hamster blood-vessel smooth muscle cells (Fig. $1 \mathrm{~J}$ ), while striated muscle cells were negative with $s m-1$. The monoclonal antibody $s r-1$ was not reactive with hamster (muscle) tissues. The monoclonal actin antibody RAC1 showed a striated pattern in hamster cardiac and skeletal muscle (Fig. $1 K$ ). No reaction was found with RAc1 in hamster smooth muscle. The connective tissue fibroblasts and endothelial cells of, for example, hamster tongue stained strongly cells in a filamentous fashion with the polyclonal and monoclonal antibodies to vimentin (Fig. $1 \mathrm{~L}, \mathrm{M}$ ). No reaction with the vimentin antibodies was seen in smooth muscle, skeletal muscle and cardiac muscle cells. No reaction was seen in epithelial cells with the wimentin antibodies. 


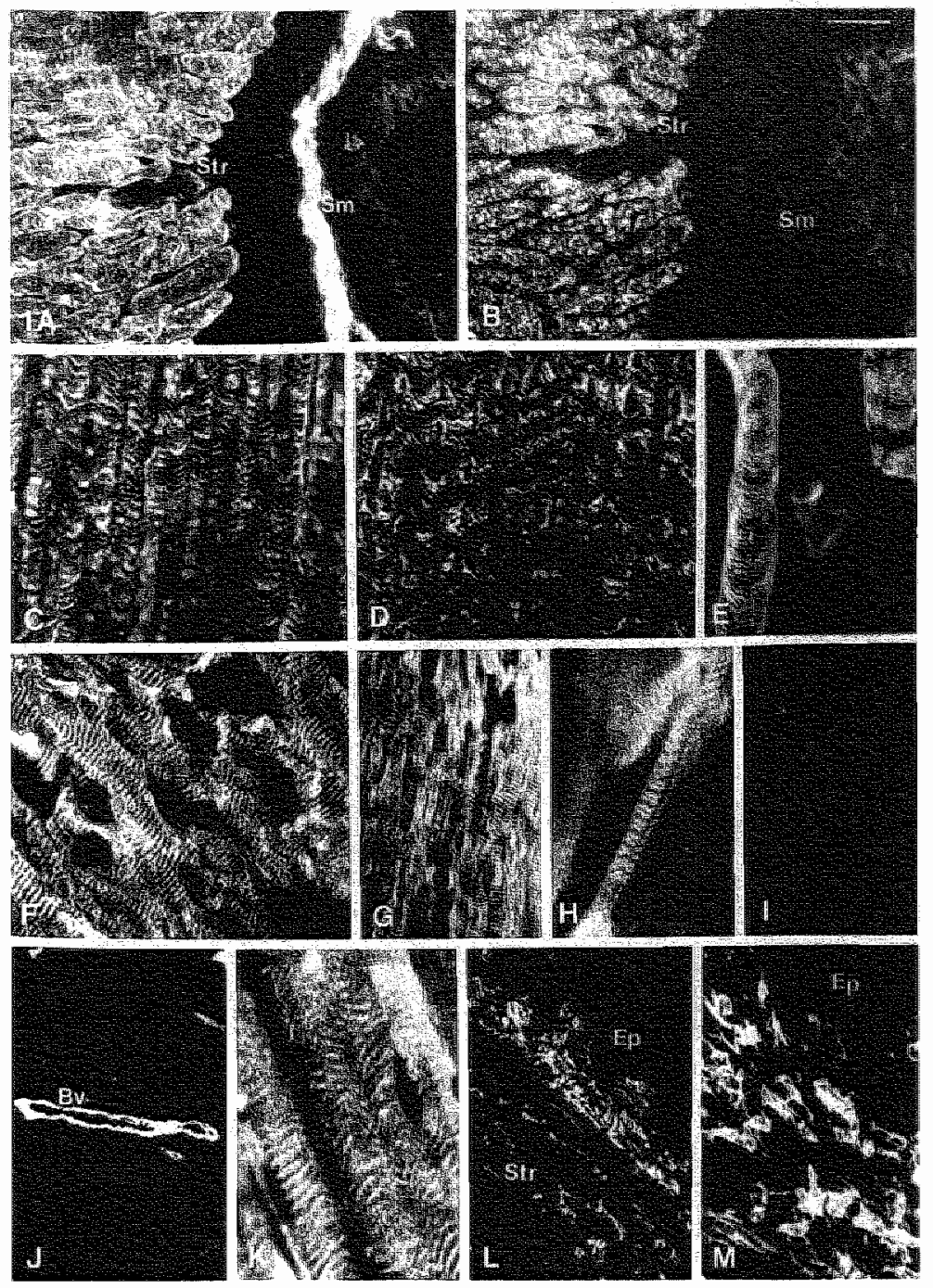

Figure 1: Indirect immunofluorescence of hamster muscle tissues incubated with antibodies to desmin, tittin, vimentin and smoath muscle actin to test their tissue specificity in this species. A, B) 10 oublo immunofudescence micrographs of hamster esophanus stained with pDes (desmin; A) and 9010 (titin; B. Wote the reaction of desmin in smooth and striated-muscle (Sm and Str, respectively), and titin positivity only in striated muscle. C, D) double-immunofiuorescence migrographs of hamster skeletal muscle from hind limb, staned with both pDes (C) and 9D10 (D). E) Reaction pattern of hamster skeletal muscle of the hind limb with pTitin. F.J) Hamster heart muscle stained with pDes (F), p Titin $10, H$, 9010 "ll and sm.1 la-smooth muscle actim; Jl. Note that the monoclonal titin antibody and sm-1 do not react with thamster heart muscle cells; By" blood vessel. K) Reaction pattern of hamster skeletal muscle of the hind limb with FAc1. L, Mi Harrister tongue, showing a positiwe reaction in the connective tissue fibroblasts with antibody pWim (wimentin: $L$ and AV203 (vimentin; M): Ep: squamous epithellum; Str: strated muscle. Bar indicates 40 um for A-D, M; $25 \mu \mathrm{m}$ for E, F; $100 \mathrm{~km}$ for $\mathrm{G}, \mathrm{l}, \mathrm{J}, \mathrm{L}, \mathrm{H}, \mathrm{\mu m}$ for $\mathrm{H} ; 16 \mathrm{~mm}$ for $\mathrm{K}$ 

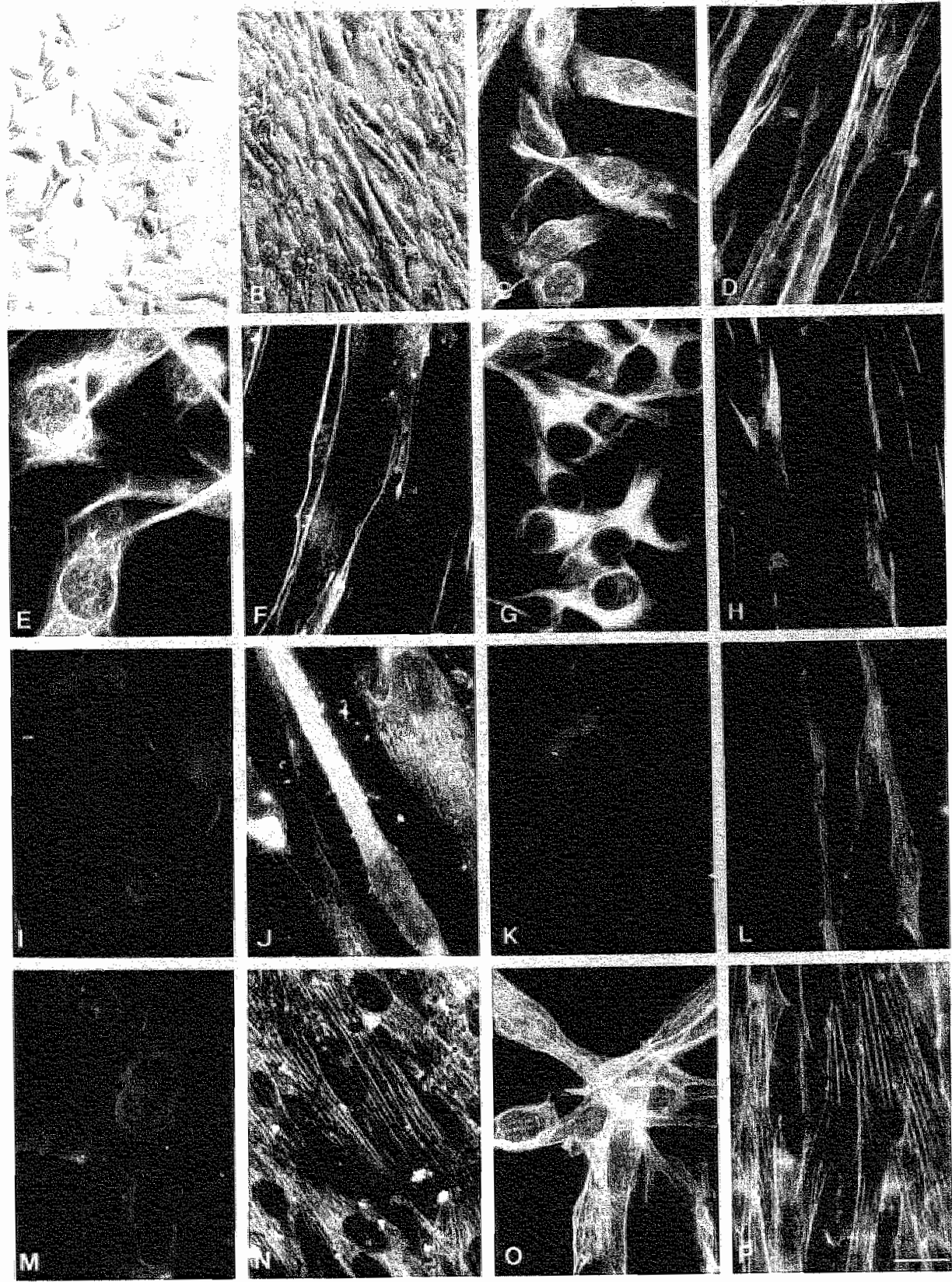

Figura 2: Phase-contrast $(A, B)$ and immunofluorescence micrographs $\mid C$. $P \mid$ of polygonal $B H K-21 / C 13$ calls $A, C, E, G, I, K, W, O$ and elongated $B H K-21$ cells grown for 4 days on low-serum medium $I B$,

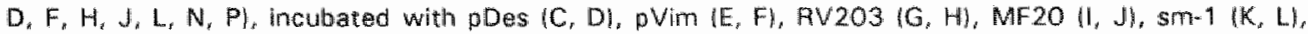

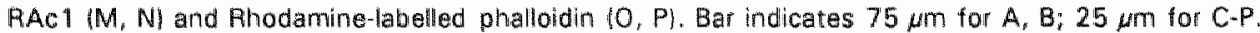


When subjected to an alteration in culture conditions, i.e., change from growth medium containing $10 \%$ normal bovine serum to a medium containing $2 \%$ normal horse serum. all three established BHK-21 cell lines showed cell elongation after 3/4 days (compare Fig. $2 \mathrm{~A}$ with $2 \mathrm{~B}$ ) in at least $50 \%$ of the cells. Hoechst 33258 staining expariments showed round nuclei in the polygonal BHK-21 cells, while the nucleus changed to a more cigar-like shape after the first signs of cell elongation. Hoechst 33258 staining also revealed some: multinucleated cells after 4 days of differentiation, most probably as a result of call fusion.

\section{Antibody reaction patterns in non-elongated $\mathrm{BHK}-21 / \mathrm{C} 13$ cells}

In this study we used BHK-21 cell lines from three different sources. The staining patterns of the different polyclonal and monoclonal antibodies in the indirect immunofluorescence assays were virtually identical for all three BHK-21 cell lines. In the polygonal, non elongated BHK-21 cells (Fig. 2A) filamentous staining was seen with both desmin antisera (Fig. 2C) and with the vimentin antisera (Fig. 2E, G). Rhodamine-labelled phalloidin showed a stress fiber-like pattern in the polygonal BHK-21 cells (Fig. 20). No reaction was found with pTitin, 9D10, MF20, sm-1, sr-1 and RAc1 (Fig, 21, M, K, 3A).

Table 2: Expiression pattern of muscle-specific proteins in elongating BHK-21 cells.

\begin{tabular}{|c|c|c|c|}
\hline $\begin{array}{l}\text { Antibody/ } \\
\text { reagent }\end{array}$ & $\begin{array}{l}\text { Cells in } 10 \% \text { normal } \\
\text { bovine serum } \\
\text { (polygonall }\end{array}$ & $\begin{array}{l}\text { Cells } 2 \text { days after } \\
\text { medium switch to } 2 \% \\
\text { horse serum (polygonal) }\end{array}$ & $\begin{array}{l}\text { Cells } 4 \text { days after } \\
\text { medium switch to } 2 \% \\
\text { horse serum (elongated) }\end{array}$ \\
\hline $\begin{array}{l}\text { pDes; RD301; } \\
\text { pVim; RV } 203\end{array}$ & Fillamentous & Filamentous & Bundles of filaments \\
\hline pTitin; 9D10 & Negative & $\begin{array}{l}\text { Punctate pattern in } \\
50 \% \text { of the ceils }\end{array}$ & $\begin{array}{l}\text { Striation in } 50 \% \text { of the } \\
\text { cells; remaining cells } \\
\text { filiamentous pattern }\end{array}$ \\
\hline$M F 2 O$ & Negative & Negative & $\begin{array}{l}20 \%-30 \% \text { of the cells } \\
\text { filamentous staining }\end{array}$ \\
\hline$s m-1$ & Negative & Negative & $\begin{array}{l}1 \%-5 \% \text { of the cells } \\
\text { filamentous staining }\end{array}$ \\
\hline$s r+1$ & Negative & Negative & Negative \\
\hline RAC 1 & Meglative & Negative & $\begin{array}{l}\text { Stress tibers with } \\
\text { striation }\end{array}$ \\
\hline $\begin{array}{l}\text { Rhodamine- } \\
\text { Phalloidin }\end{array}$ & Fllamentous & Filamentous & $\begin{array}{l}\text { Stress fibers with } \\
\text { striation }\end{array}$ \\
\hline
\end{tabular}

\section{Antibody reaction patterns in elongated $\mathrm{BHK}-21 / \mathrm{C} 13$ cells}

After 2 days of growing in low-serum medium, when BHK-21 cells had not yet elongated, punctate staining was seen with the polyclonal and monoclonal antibodies to titin (Fig. 

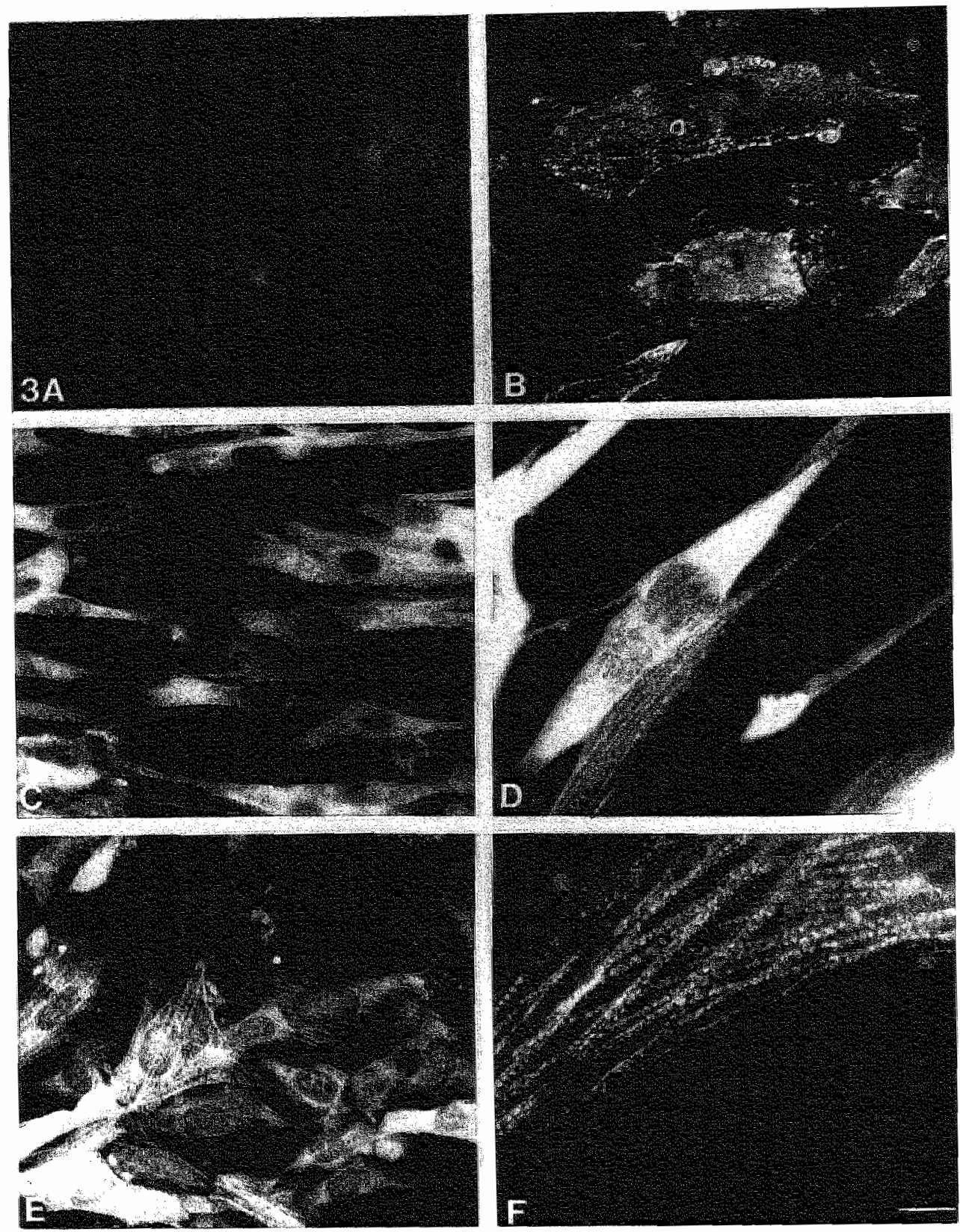

Figure 3: Hndirect immunothorescence study with the polyclonal titin antiserum (pTitin; $A, C, D)$ and

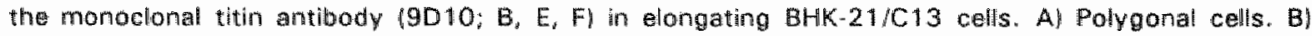
Cells on llow-serum medum for 2 days. C-F Elongated cells, grown on low-serum medium for 4 days. Bar indicates 25 ym for $A \cdot C, E ; 0$ um for $D, F$. 
3B). The reaction patterns obtained with the other muscle-specific antisera ware similar to those observed in the cells grown on high-serum medium.

After 4 days of growth under low-serum conditions the elongated BHK-21 calls showed a strong reaction with the titin antisera. In some cells a diffuse to filamentous titin reaction pattern was seen (Fig. 3C, D), but in most of the cells clear striation was observed with the titin antibodies (Fig. 3D, E, F), which seemed to be concentrated along stress fibers. With the desmin antisera filementous staining was seen in some cells. while most cells showed parallel bundles of desmin IFP. No desmin striation was noted (Fig. 2D). A similar staining pattern was seen with the vimentin antisera (Fig. $2 \mathrm{~F}$. H), but both the polyclonal and the monoclonal vimentin antibodies showed much weaker staining of elongated cells than of polygonal cells. The monoclonal antibody MF2O to all types of striated-muscle myosin, showed a strong filamentous reaction in 20-30\% of the elongated BHK-21 cells (Fig. 2J). No reaction was seen with the $\mathrm{sr} 1$ antibody. A positive reaction was also seen in some $(1-5 \%)$ of the elongated BHK-21 cells with the sm-1 antiserum (Fig. 2L). Most of these sm-1 positive cells showed a stress fiber-like pattern, as was also observed with the monoclonal antibody to RAc1 to actin and the Rhodamine-labelled phalloidin IFig. $2 \mathrm{~N}$, P). Striation patterns were seen in most of the cells reacting with phalloidin. RAc1 stained virtually all cells in a differentiated cell culture, with the impression of variable striation along stress fibers, but always less evident than with phalloidin.

\section{Immunoblotting of titin, desmin and myosin}

The results of the immunoblotting assays using antibodies to titin, desmin and skelletal muscle myosin (Fig. 4) confirmed the immunofluorescence studies. In the polygonal BHK-

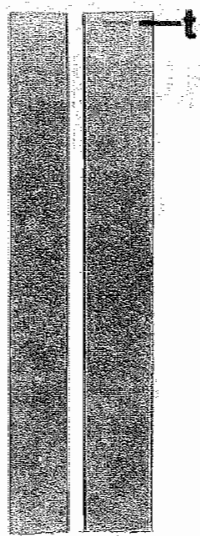

$4 a$

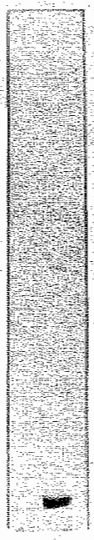

c

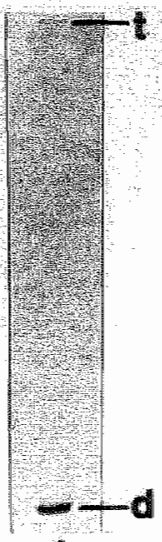

d

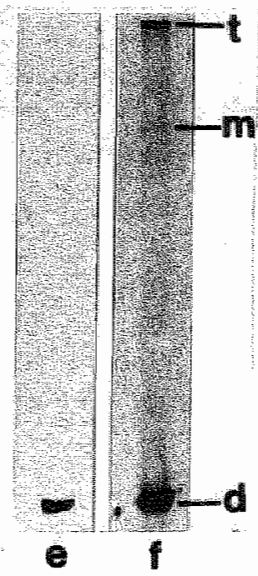
21 cells a positive reaction was found only for desmin (RD301; Fig. 4, lane c). No immunoreactivity was obtained after incubations with the monoclonal antibody to titin 19010: Fig. 4, lane a) or with the monoclonal antibody to skeletal muscle myosin (MF20; Fig 4., lane e). In cytoskeletal preparations of elonga ted BHK-21 cells all these three antisera (9D10, RD301 and MF2O) showed a specific positive reaction at the expected molecular weight levels of titin, desmin and myosin. respectivelly.

Figure 4: Immunoblots of cytoskeletal axtracts of polygonal llanes $a, c$, el and elongated (lanes bi $d, f$ ) BHK-21/C13 cells. lanes a and (b) Incubated only with the monoclonal titin antibody (9D10). anes $c$ and di After the titin incubation as shown in $a$ and $b$, these blots were reincubated with the monoclonal desmin antityody (AD 3011. lanes e and if The blots shown in lanes $c$ and $d$. were again reincubated with the monoclonal sheletal muscle myosin antibody (MF20). Note that titin and myosin were only detected in the elongated cells, while desmin is present in both polygonal and elongated cells. The specificity of antibodies to myosin and titin is abvious from the negative reactions in lanes $c$ and $a$.

\section{D-gel electrophoresis}

Cytoskeletal preparations from metabolically $1^{35}$ SI-labelled polygonal and elongated BHK-21/C 33 cells, were analyzed by means of $2 \mathrm{D}-\mathrm{gel}$ electrophoresis, using isoelectric focussing as the first dimension and SDS-containing polyacrylamide gels as the second dimension.

Figure 5 shows a comparison of the- 


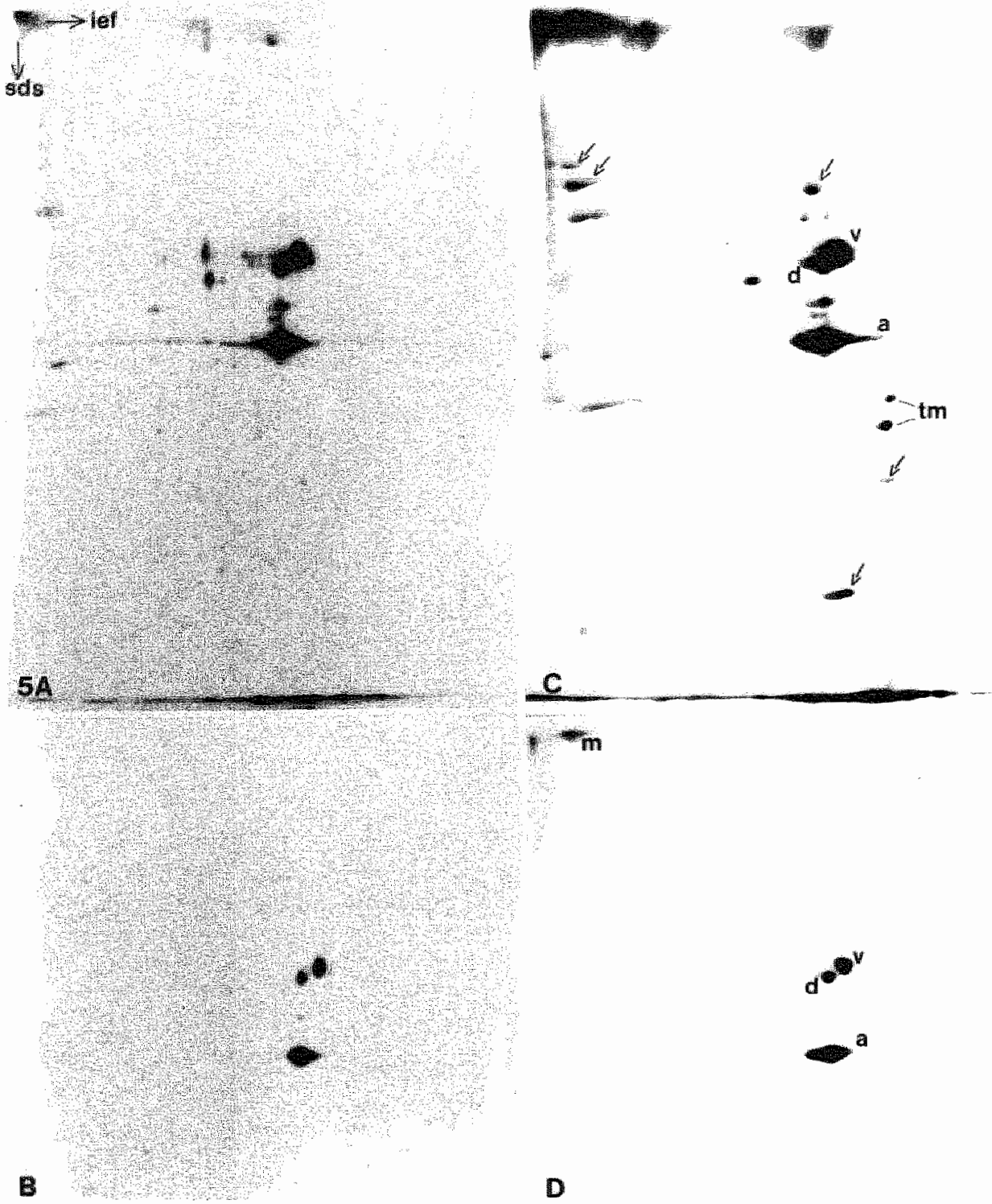

Fligure 5: Autoradiopraphs of $2 \mathrm{D}$-gel electrophoretic analyses o polygonal $\left(\mathrm{A}_{s} \mathrm{~B}\right)$ and elongated $(\mathrm{C}, \mathrm{D})$ BHK-2 / C 13 cells. The films shown in $B$ and $D$ were exposed for a period six times shorter than fillms $A$ and $C$, respectively. Airrows indicate proteins that seem to be synthesized only in elongated celis. This is also the for specific tropomyosins (tm) and the myosin $200 \mathrm{kDa}$ protein (m). vimentim, d: desmin and a: actin. 
se analyses, indicating a number of profound changles in the protein sythesis pattems upon elongation. The most significant proteins, of which the synthesis is initiated or enhanced as a result of differentiation are indicated by arrows in figure $5 \mathrm{C}$ and $\mathrm{D}$, and include constituents with electrophoretic mobilities similar to myosin heavy chain $(m)$ and some of the tropomyosins (tm). Next to these, several other, yet unidentified proteins are synthesized only in the elongated cells. It was not possible to obtain a clear separa-tion of the different isoforms of actin.

\section{DISCUSSION}

Initial studies on the nature of BHK-21/C 13 cells $[32,33,48-50]$ suggested thay had a fibroblast-like nature. Since several investigators $[1,9,13,56]$ have shown that BHK-21 cell culltures contain desmin, the muscle-specific IFP, they are now generally regarded as smooth muscle cells. The presence of a second type of IFP. i.e., vimentio did not interfere with this interpretation, since this IFP is also coexpressed with desmin in developing muscle and many adult smooth muscle cells [1, 9, 52]. However, in a recent study [11] Foddy et al. suggested an origin of BHK-21/C13 cells from kidney tubular epithelium on basis of their finding that similar lectins occur on the cell surface of BHK cells and those kidney cells. In line with this idea is the finding of Southgate ef al. 1471, who demonstrated the expression of a tuype 11 keratin-like component in a fraction of BHK-21 cell cultures. We could not find keratin expression in the three different badges of cell lines used in this study (unpublished results). Taking together the data published sofar, it becomes evident that the discussion about the origin of this cell line is not yet settled.

In the present study we have noticed that cultured BHK-21 cells can change their morphology from polygonal to elongated, with some fused cells, upon a switch in their growth medium from $10 \%$ bovine serum to $2 \%$ horse serum. These changing conditions, normally used to initiate differentiation in cultured skeletal and cardiac muscle call cultures, were found to have the same effect on three different batches of BHK-21 cells (see Materials and Methods).

In both the polygonal and elongated phenotypes desmin and vimentin were detected. No quantitative change in desmin immunoreactivity was noticed upon elongation, although the desmin IFP arrangement adapted to the elongated cell shape. In contrast, vimentin immunoreactivity was much less pronounced in elongated cells as compared to the polygonall cells, an observation also made in other differentiating muscle cell cultures [16. 38]. The phenomenon may also parallel the down-regulation of vimentin in differentiating muscle cells in vivo $[50,53]$.

Besides antibodies directed against IFP desmin and vimentin, we have applied antibodies to titin to study the type of muscle differentiation these BHK-21 cell cultures exhibit. Titin has been desciribed as a specific marker for striated muscle differentiation $110,12,25$. $44,54,591$. Our present studies in hamster tissues show that the two titin antibodies used in this study specifically recognize striated muscle. However, in hamster only the polyclonal titin antibody reacted also with cardiac muscle cells. The fact that both antibodies did react with the elongated BHK-21 cells strongly indicate that this cell culture is of a striated-muscle phenotype. The reactivity patterns with the striatedmuscle-specific myosin antibody MF20 support this assumption. These results are in accord with preliminary studies. $P$. van de Ven, Department of Cell Biology and Histology. University of Nijmegen. Nijmegen. The Netherlands; Unplubishedf in cultures of human skeletal muscle myoblast. These cells contain desmin, but not titin at the undifferentiated stage. When stimulated to elongate, desmin expression remains, while titin syrthesis is induced. These findings are also completely in line with data from Hill et al. [23], who found titin and myosin expression upon differentiation of desmin-containing chick myoblasts. Also the finding that the smooth muscle-type actin antibody sm-1 does not 
react with the polygonal BHK-21 cells and only reacts with a small percentage of the elongated cell population indicated that BHK-21 cells do not represent smooth-muscle cells $[1,9,13,15,49,52,56]$. The positivity in some of the elongated cells may be explained by the finding of Woodcock-Mitchell et al. [59], that actin isoform expression may change under certain physiological and experimental conditions. Antibody RAc1 to actin was shown to react only in hamster striated muscle cells, and not in smooth muscle cells. Again, the striated muscle phenotype of BHK-21 cells was further substantiated by our finding that BAc1 reacted with elongated (differentiated) BHK-21/C 13 cells in a moreormless striated fashion.

A punctate titin staining pattern was found after 2 days of growing under llow-serum conditions. Such titin organization has recently been observed in in wivo and in witro during early stages of myofibrillogenesis $16,44,541$. During embryogenesis it indicates the first appearance of cardiac or skeletal muscle-type of differentiation [12, 44]. It should be kept in mind that in the embryonic development of cardiac muscles, titin is: expressed even before desmin [44]. Although in BHK-21 cells desmin is present in both polygonal and alongated phenotypes, titin is still the earliest marker of striated muscle differentiation, and was expressed even before evident cell elongation was seen. After elongation and fusion of the BHK-21 cells, evident striation of titin was found. Skeletal muscle myosin, present in $20-30 \%$ of the elongated BHK-21 cells, was found in a filamentous pattern. No striation of myosin was seen in the myosin pasitive cells. This observation, in combination with the finding that myosin expression las detected by MF201 occured later than titin expression, shows that titin is an early indicator of striated muscle differentiation.

In the 20-gel electrophoretic analyses we have found that during elongation of the BHK21 cells synthesis of a number of specific proteins is initiated. The appearance of 200 KDa myosin and tropomyosins in the gels of differentiated cells again indicates the muscle phenotype of these cells $[5,10]$ and partly substantiates our immunohistochemical findings. Future studies will have to reveal the identity of several other, not yet characterized protein components that are found by $2 \mathrm{D}$-gel electrophoresis to be expressed only, or in a significantly higher quantity in differentiated BHK-21 cells.

We conclude that BHK-21 cell cultures may be used to study cell biologicall aspects of striated muscle cell differentiation. The advantage of BHK-21 cell lines over several other muscle cell lines that can be induced to differentiate is that BHK-21 cells can be kept in continuous cultures. The muscle cell cultures $\mathrm{C} 2 \mathrm{C} 12, \mathrm{~L} 8$ and T984, for example, can be used only for limited passage numbers 131,381 . Using appropriate antibodies in the indirect immunofluorescence assay the sequence of expression and structural organization of some of the striated muscle-specific constituents can now be studied in BHK-21 cell cultures.

\section{REFERENCES}

1. Absher M, Woodcock-Mitchell J, Mitchell J. Baldor L. Warshaw D. Characterization of vascular smooth-musicle cell phenotype in long-term culture. In Vitro Cellular Dev. Biol. 25, 183-192, 1989.

2. Anderton B. Intermediate filaments: a family of homolagous structures. 1 . Muscle Res. Cell Motil. $2,141-166,1981$.

3. Bader $D$, Masaki T. Fischman DA. Immunochemical arvalysis of myosin heavy chain during avian myogenesis in wivo and in vitro. J. Cell Biol. 95, 763-770, 1982.

4. Broors JLV, Carney DN, Klein Rot M, Schaart G, Lane EB, Vooijs GP, Ramaekers FCS. Intermediate filament proteins in classic and variant types of small cell fung carcinomas cell lines: A biochemical and immunochemical analysis using a panel of monoclonal and polychonal antibodlies. J. Cell Sci. 83, 37.60, 1986 .

5. Butler-Browne GS, Barbet JP. Thomell LE. Myosin heavy and light chain expression during human skeletal muscle development and precocious muscle maturation induced by thyroid hormone. Aniat. Embryol. $181,513.522,1990$. 
6. Colley NJ, Tokuyasu KT, Singer Su. The eaty expression of mivotibritio protains in round postmitotic myoblasts of embryonic skeletal muscle. J. Cell Soi. 95, 11-22, 1990 .

7. Debus $E_{n}$ Weber $K$, Osborn M. Monocional antibodies to desmin, the muscle spuciffe intermediate

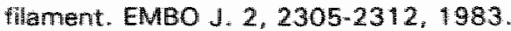

8. Edgar AJ. Isolation and characterization of getsolin from cutured BHK cells. A. Musclo Aes. Call Motil. $10,475-482,1989$.

9. Fager G, Hansson GK, Gown AM, Larson DM. Skall O, Bondiers G. Human arterial smoothumuscle cells in culture: inwerse relationship befween prolferation and expression of contractile proteins. In Vitro Cellular Dew. Biol, 25, 511-502, 1989.

10. Fischman DA. Myotibrillogenesis and the morphogenesis of skeletal muscle. In Myology: Basic and Clinical. leds: Engel AG and Banker Bal McGraw-Hill, New York, pp 5-30, 1986.

11. Foddy L, Stamatoglow SC. Hughes RC. An endogenous carbohydrate binding of baby hamster kidney (BHK-21/C13) cells. Temporal changes in cellular expression in the deweloping kidney. $J$ Cell Sei, $97,139-149,1990$.

12. Furst DO. Osborn M. Weber $K$. Myogenesis in the mouse embryo: diffrential onset of oxpresian of myogenic proteins and the inwolvement of titin in myotbril assembly, J. Cell Biol. $109 ; 1517$ $527,1989$.

13. Frank ED, Tuszynski $P$, Warren L. Locallization of wimentin and desmin in BHK21/C13 cellis arid in baby hamster kidney. Exp. Cell Res. 139, 235-247, 1982.

14. Firanke WW, Mol R. Cytoskeletal components of Iymphoid organs. I. Synthesis of cytokeratins 8 and 18 and desmin ün subpopulations of extrafollicular reticulum cells of human lymph nodes, tonsils and spleen. Differentiation 36, 145-163, 1987.

15. Gard $\mathrm{DL}$. Bell PB, Lazarides $\mathrm{E}$. Coexistence of desmin and the fibroblastic intermediate flament subunit in musclie and nonmuscle cells: identification and comparative peptide analysis. Proc. Natl. Acad. Sci. USA 76, 3894-3898, 1979.

16. Gard $\mathrm{DL}$, Lazarides $\mathrm{E}$.. The synthesis and distribution of desmin and vimentin during myogenesis in vitro. Cell 19,263-275, 1980 .

17. Gassner D. Myofibrillar interaction of blot immunoaffinity-purified antibodies against natiwe titin as studied by andirect immunofluorescence and immunogold staining. Eur. J. Cell Biol. 40, 176-184, 1986.

18. Gauthier GFS, Lowey S, Benfleld PA, Hobbs AW. Distributions and properties ol myosin isozymes in developing avian and mammalian skeletal muscle vibres. J. Cell Biol. 92,471-494, 1982.

19. Greaser ML. Handel SE, Wang SM, Schultz E, Bulinski JC, Lessard JL. Assembly of titin, myosin, actim, and tropomyosin into myofibrils in cultured chick cardiomyocytes. In. Callular and Molecular Biology of Muscle Deveiopment. UCLA Symposiumi on Molecular and Cellular Biology, Now Series, Vol. 93 leds. Stockdale F, Kedes L) Alan A. Liss, New York, pp 246-257, 1989.

20. Handel SE, Wang SM, Greaser ML, Schultz E, Buhnski JC, Lessard JL. Skeletal musele myofibrillogenesis as revealed with a monoclonal antibody to titin in combination with detection of the alpha and gamma isoforms of actin. Dev. Biol. 132, 35-44, 1989.

21. Heuijerjans $T$, Pieper F, Ramaekers FCS, Timmermans LJM, Kulipers HJH, Bloemendal H, Venroo倠 van WJ. Association of mRNA and elf2a in cells lacking vimentin. Expl. Cell Res. 181, 317-330. 1989.

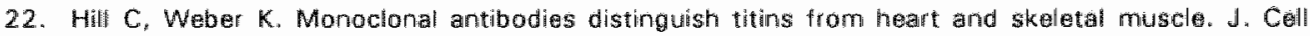
Biol. 102, 1099-1108, 1986 .

23. Hill CS, Duran 5 , Zhongxiang $L$, Weber $K$, Moltzer $H$. Titin and myosin, but no desmin are linked during myofibrillogenesis in postmitotic mononucleated myoblasts. ل Cell Biol. 103, 2185-2196. 1986.

24. Hoch HC, Staples RC. Visualization of actin in situ Rhodamine-conjugated Phalloidin in the Fungus Uromyces Phaseovi. Eur .J. Cell Biol. 32, 52, 1983.

25. Isaacs WB, Kim IS, Struve A, Fulton AB. Biasynthesis of titin in cultured skeletal musche cells. J Cell Bial. $109,2189-2195,1989$.

26. Kotfer A, Dickens MJ. Isolation and characterization of actin from cultured BHK cells. J. Muscle Fes. Cell Motil. 8, 397-406, 1987.

27. Koffer A. Edgar A.J, Bamburg JF. Identification of two species of actin depolymerizing factor in cultures of BHK cells. J. Muscle Res. Cell Motil. 9, 320-328, 1988.

28. Kwast TH wan der, Vuzevsky VD, Ramaekers F, Bousema MT, Joost T wan. Primary cutaneous adenoid cystic carcinoma: case report, immunohistochemigtry, and review of the literature. Br. $J$. Derm. $118,567-568,1988$.

29. Laemmli UK. Cleavage of structural proteins during the assembly of the head af bacteriophage T4. Nature $227,680 \times 685,1970$.

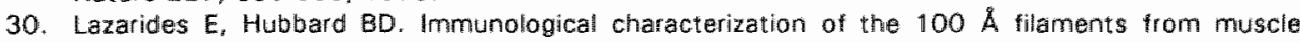


Proc. Nath, Acad. Sol. USA 76, 4344-4348, 1976 .

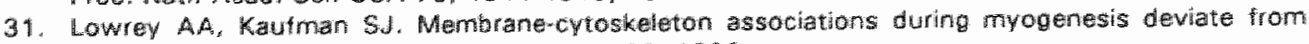
traditional definitions. Exp. Cell Res. $183,1 \times 23,1989$.

32. Macpherson 1, stoker M. Folyoma transformation of hamster cell clones - an investigation of genetic factors affecting cell competence. Virology $16,147 \cdot 151,1962$.

33. Macpherson 1. Characteristics of hamster cell clone transformed by polyoma wirus. J. Math. Cancer Inst. 30, 795-815, 1963.

34. Mandavi $V$, Strehler EE, Periesamy M, Wieczorek D, Izumo S, Grund S, Strehler MA, Nadal-Ginard B. Sarcomeric myosin heavy chain gene family, organitation and pattern of expression. Mol. Biol. Mugcle Dev, $29,345-361,1986$.

35. Maruyama K, Natori $\mathbb{R}$. Nanomura $Y$. New elastic protein from muscle. Nature 262, 58-60, 1976.

36. Molengraft $F$ van die, Ramaekers $F$, Jap $P$, Voois $P$, Mungyer G. Changing intermediate sized filament patterns in metastatic hepatocellular carcinoma cells of the guinea pig. Virchows: Arch. B $51,285-301,7986$

37. Ofarmell PH. High resolution twa-dimensional electrophoresis of proteins. J. Biol. Chem. 230. $4007-4021,1975$.

38. Piepu FH, Slobbe AL. Famaekers F, Cuypers HT, Bloemendal H. Upstream regions of hamster desmin and vimentin genes regulate expression during in vitro myagenesis. EMEO $J .6,3611$. 3618,1987 .

39. Pieper FA, Schaart G, Kimpentort PJ, Henderik JB, Moshage Hu, Ramaekers FCS, Berns A, Bloemendal H. Transqenic expression of the muscle-specific internediate filament protein desmin in non-muscle cells. J. Col Biol. 108, 1009-1024, 1989.

40. Ounian AA, Franke WW. Heteropalymer of vimentin and desmin in vascular smooth muiscle tissue and cultured baby hanster kidney cells demonstrated by chemical crosslinking. Prac. Natl. Acad. Sci. $79,3452-3456,1982$.

41. Ramakers FCS. Hulismans $A$, Moesker $O$, Kant $A_{\text {, }}$ lap $P$, Herman $C$, Vooijs P. Monoctonal antibodies to keratin filaments, specific for glandular epithelia and their tumors. Use in surgical pathology. Lab inwest. 49, 353-361, 1983.

42. Aamaekers FCS, Puts JJG, Moesker O, Kant A, Huijmans A, Haag D, Jap PHK, Herman CJ, Vooijs GP. Antibodies to intermediate fitament proteins in the immunohistochemical identification of human tumours: an overview. Histochemical J.15,691-713,1983.

43. Ramaekers FCS, Moesker O, Huijsmans A, Schaart G, Westerhof G, Wagenaar SjSi, Herman CJ, Voojis GP. Intermediate filaments proteins in the study of tumor heterogeneity: an in-depth study of tumprs of the urinary and respiratory tracts. Ann. NY Acad. Sci. $455,614 \cdot 634,1985$.

44. Schaart $G$, Viebahn $C$, Langmann $H$, Ramaekers $F$. Desmin and titin expression in early postimplantation mouse embryos. Development 107, 585-596, 1989

45. Skalli 0 . Ropraz P. Trzeciak A, Benzonana $G$, Gllesen D, Gabbiani G. A monocilonal antibody against a-smooth muscle actin: a new probe for smooth muscle differentiation. J. Cell Biol. 103. $2787-2796,1986$

46. Skalli $O$, Gabbiani G, Baba: F, Seemayer TA, Pizzolato G, Schürch W. Intermediate fliament proteins and actin isoforms as markers for soft tissue tumor differentiation and origin. II Rhatidomyosarcomas. Am. J. Path. 130, $515-531,1988$.

47. Southqate J, Treidosiowicz LK, Hodges GM. BHK-21/C13 cells express a single $45 \mathrm{~K}$ Dalton type II cytokertin-like component integrated with the desmindwentin intermediate filament arrays. In: Structure and Functions of the Cytosketeton. Biological and Physhopathological Aspects. led. Rousset BAFI John Libbey Eurotext London, p528 (abstract) 1988.

43. Starger JM, Goldman RD. Isolation and preliminary characterization of 10 nm filaments from baby hamster kidney (BHK-21) cells. Proc. Natl. Acad. Sci. USA 74, 2422-2426, 1977.

49. Staber JM, Brown WE, Goldman AE, Goldman RD. Biochenticall and immunological analysis of tapidly purified $10 \mathrm{~nm}$ filaments from baby hamster kidney (BHK21) cells. J. Cell Biol. 78, 93-109. 11987 .

50. Steinert PM, Idlor WW, Goldman RD. Intermediate filaments of baby hamster kidney (BHK-21) cells and bovine epidermal keratinocytes have similar ultrastructures ary subunit domain structures. Proc. Nati. Acad. Sci. USA 77, 4534.4538, 1980.

51. Stoker MGP, MacPherson IA 1961 I Studies on transformation of hamster cells polyoma virus in vitro. Virology $14,359-370,1961$.

52. Strauch AR, Reeser JC. Sequential expression of smooth muscle and sarcomeric a actin isolorms during BC3H1 cell differentiation. J. Biol. Chem. 265, $8345.8355,1989$.

53. Tokuyasu KT, Maher PA, Singer S. Distributions of vimentin and desmin in developing chick myotubes in wivo. I. Immunofluorescence study. J. Cell Biol. 96, 1961-1972, 1984.

54. Tolkuyasu KT, Maher PA. Immunocytocnemical studies of cardiac myofibrilogenesis in early chick 
embiryos. I. Presence of immunofiuorescent titin spots in prempotibril stages. J. Call Bial, 105 , $2781.2793,1987$.

55. Towbin H, Staehelin T, Gordon J. Electrophoretic transfer of proteins from polyacrylamide gels to nitrocellulose sheets: procedure and some applications. Proc. Natl. Acad. Sci. USA 76, 4350$4354,1979$.

56. Tuszynski GP, Frank ED, Damsky CH, Buck CA, Warten L. The detection of smpoth muscle desmin-like protein in BHK21/C13 fibroblasts. J. Biol. Chem. 254,6138-6143, 1979.

57. Wang SM. Greaser ML. Immunocytochemical studies using a monocional antibody to bovine cardiac titin on intact and extracted myofibrils, J. Muscle Res. Cell Motil. 6, 293-312, 1985.

58. Wang SM, Greaser ML, Schultz E, Bulinski JC, Lin JJC, Lessard JL. Studies on cardiac myofibrillogenesis with antibodies to titin, actin, tropomyosin, and myosin. J. Cell Biol. 107, $1075-1083,1989$.

59. Woodcock-Mitchell J. Mitchell JJ, Low RB, Kieny M, Sengel P, Rubbie L, Skalli O, Jackson B, Gabbiani $G$. $a$-Smooth muscle actin is transiently expressed in embryonic rat cardiac and skeletal muscles. Differentiation 39, 161-166, 1988. 



\section{CHAPTER 3}

DIFFERENTIATION OF HUMAN SKELETAL MUSCLE CELLS IN CULTURE: MATURATION AS INDICATED BY TITIN AND DESMIN STRIATION.

P.F.M. VAN DER VEN, G. SCHAART, P.H.K. JAP, R.C.A. SENGERS, A.M. STADHOUDERS and F.C.S. RAMAEKERS

Cell and Tissue Research 270, 189-198, 1992 


\section{ABSTRACT}

This report describes a phenotyping study of differentiating human skeletal muscle cells in tissue culture. Satellite cells (adult myoblasts), isolated from biopsy material, showed a proliferative behaviour in high nutrition medium, but fused to form myotubes when grown in low-nutrition medium. The expression and structural organization of the intermediate filament proteins desmin and vimentin as well as the sarcomeric constituents $a$-actin, $a$ actinin, nebulin, myosin and especially titin during myofibrillogenesis in witro, were studied by means of indirect immunofluorescence assays. The proliferating myoblasts contained both desmin and vimentin, a-actinin and the fillamentous form af actin. Shortly after the change of medium, expression of titin, sarcomeric myasin and skeletal muscle am actin was found in mononuclear cells in a diffuse, filamentous (titin, myosin, a-actin) or punctate (titin. myosinl pattern. Four to ten days after the medium change, mature myotubes showed desmin, titin, a-actinin, nebulin, sarcomeric myosin, and actin crossstriations, while vimentin was no longer detected. We conclude that human skeletal muscle cell cultures are an appropriate model system to study the molecular basis of myofibrillogenesis. Especially the presence of desmin in a striated fashion points to a high degree of maturation of the muscle cell cultures.

\section{INTRODUCTION}

In striated muscle tissue contractile properties result from a strictly defined organization of functional proteins in the myofibrillar sarcomere [6,7]. Some of these proteins, like actin and myosin, actually drive contraction, while other constituents are known to link contractille proteins to each other ( $\alpha$-actinin, myomesin), or to keep sarcomeres in register by linking inyofibrils to each other or to the sarcolemma (desmin) [7]. In this way, the generated contractile momentum within each fiber can be guided to result in coordinated muscle contraction. Two of the most recently discovered myofibrillar constituents are the giant proteins titin [17] and nebulin [35]. The elastic titin filaments are thought to play an important role in preventing striated muscle from over-stretching [18] in regulating thick filament length [37], and in maintaining the alignment of myosin fillaments [14], while the inextensible nebulin filaments probably regulate thin filament length $[15,16]$.

It is obvious that during myofibrillogenesis, the ordering of different sets of proteins should occur very precisely and in an ordered sequence. Several in vivo and in vitro studies have been performed, in which the expression and localization of specific myofibrillar and intermediate filament proteins are described during several stages of myogenesis in heart and skeletal muscle (reviewed by Fulton and Isaacs. 181). The conclusion of these authors is that titin and not desmin, as suggested earlier $[10 \mid$, is the most likely candidate for an important organizer during myofibrillogenesis. Several contradictory observations with respect to myofibrillogenesis have been described, while many aspects still remain unclear [8]. We have monitored in vitro differentiation of aneurally cultured human skeletal muscle cells, and characterized different steps in this process by using antibodies to the intermediate filament proteins (IFPS) desmin and vimentin, next to the myofibrillar proteins $a$-actinin, titin, nebulin, myosin and a-actin.

The aim of this study therefore, was to examine to what extent maturation in human skeletal muscle celi cultures proceeds under optimal conditions of growth and differentiation. On the basis of expression and organization of structural constituents we tested whether these calls show a sufficiently high degree of maturation for use in studying human myofibrillogenesis. 


\section{MATERIALS AND METHODS}

\section{Muscle cell cultures}

Satellite cells were isolated from muscle biopsies obtained during reconstructive orthopedic surgery from patients without known muscular disease, using trypsin and collagenase, essentially according to Yasin et al. [8] and Benders et al. [4]. The obtained cell suspension was filtered ( $30 \mathrm{~km}$ nylon mesh) to remove possible intact myofibers, and seeded in $\varnothing 35 \mathrm{~mm}$ culture dishes (Costar. Cambridge, MA, USA) in $2 \mathrm{ml}$ Dulbecco's modified Eagle's medium (DMEM; Gibco BRL. Paisley, UK) containing $20 \%$ fetal calf serum (HyClone Laboratories Inc.., Logan, UT, USA), $2 \%$ chick embryo extract (Flow Laboratories, Irvine, UK), $2 \mathrm{mM}$ glutamine (Gibco BRL), $100 \mathrm{U} \cdot \mathrm{ml}^{-1}$ penicillin (Gibco BRL) and $1 \mu \mathrm{g} . \mathrm{m}^{21}$ streptomycin (Gibco BRL), and grown to about $80 \%$ confluence in a humidified incubator (Heraeus, Hanau, FRG) at $37^{\circ} \mathrm{C}$ and $5 \% \quad \mathrm{CO}_{2}$. Then cells were trypsinized and reseeded in $\varnothing 35 \mathrm{~mm}$ culture dishes at a maximal split ratio of $1: 6$. Cells were frozen in liquid nitrogen in culture medium complemented with 10\% DMSO (Merck, Darmstadt, FRG) after trypsinization. For indirect immunofluorescence experiments these cells were thawed quickly, grown to near confluency in $\varnothing 35 \mathrm{~mm}$ culture dishes, trypsinized and reseeded onto 10 well multispot microscopic slides (Cel-line Associates Inc. Newfield, NJ, USA). After 16 to $24 \mathrm{~h}$ the medium as described above, was replaced by an Ultroser $G$ (Gibco BFL) containing culture medium described by Benders et al. (1991), except that the rat brain extract was replaced by human brain extract (HBE: see below). Differentiation of the muscle cells normally occured upon confluency, but was in mast experiments induced before myotubes became visible, by changing the highnutrition culture medium to a low-nutrition medium IDMEM, $0.4 \%$ Ultroser $\mathrm{G}, 5 \% \mathrm{HBE}$, glutamine and antibiotics) just before the cultures reached confluency. The medium was changed every 3 days. During differentiation, every 3 days half of the medium was replaced by fresh medium. For cell fractionation experiments, cells were cultured in 75 $\mathrm{cm}^{2}$ tissue culture flasks (Costar).

Human brain extract (HBE) was prepared by homogenizing normal, adult tissue of the frontal labe of the cerebral cortex obtained at autopsy 1 h after death, in DMEM, using a Potter-Elvehjem glass-teflon homogenizer and a pestle with a clearance of $0.05 \mathrm{~mm}$. After centrifugation of the homogenate for $1 \mathrm{~h}$ at $100,000 \mathrm{xg}$, the supernatant was stored at $-70^{\circ} \mathrm{C}$. Before use, the HBE was sterilized using a $0.2 \mu \mathrm{m}$ filter (Schleicher \& Schuell, Dassel, FRG). The concentration of HBE in the culture media was equivalent to $10 \mathrm{mg}$ tissue per $\mathrm{ml}$ medium.

\section{Muscle tissue specimen for immunohistochemistry}

The skeletal muscle tissue used for our immunohistochemical study was obtained at autopsy of a 1-day-old boy without known muscle disorder. The child was born after a pregnancy of almost 28 weeks. Immunohistochemistry was carried out together with routinely performed histopathological staining for diagnostic reason. The tissue was frozen in liquid nitrogen immediately after dissection.

\section{Indirect immunofluorescence assays}

Muscle cells cultured on glass slides were briefly rinsed in phosphate-buffered saline (PBS: $137 \mathrm{mM}$ sodium chloride (Merck), $13 \mathrm{mM}$ di-sodium hydragen phosphatte dihydrate $\left(\mathrm{Na}_{2} \mathrm{HPO}_{4} \cdot 2 \mathrm{H}_{2} \mathrm{O}\right.$; Merck), $3 \mathrm{mM}$ potassium dihydrogen phosphate $\left(\mathrm{KH}_{2} \mathrm{PO}_{4} ; \mathrm{Merck}\right), \mathrm{pH}$ $7.4)$ and fixed in methanol (Merck; $-20^{\circ} \mathrm{C}, 30-60 \mathrm{sec}$ ) and acetone (Merck: $-20^{\circ} \mathrm{C}, 5-10$ sec) at several time intervals following the medium change. When not immediately 
tested, the slides were frozen at $-25^{\circ} \mathrm{C}$ after air-drying. Cryostat tissue sections 16 pm thick were air dried and treated for $10 \mathrm{~min}$ with $0.5 \%$ Triton $X-100$ in PBS. Before incubation the sections were rinsed in PBS. The cells or tissue sections were incubated with the primary antibody for 30 min at room temperature. After extensive washing for 30 min in PBS they were incubated with fluorescein isothiocyanate- (FITC) conjugated rabbit anti-mouse Ig or swine anti-rabbit lg (Dakopatts, Glostrup, Denmark). The slides were washed again in PES and mounted in Gelvatol Mansanto, St. Louis, MO. USA). Slides were viewed with a Zeiss Axioskop microscope with epifluorescent illumination (Carl Zeiss, Oberkochen. FRG). Pictures were taken using 400ASA TMY film (Kodak. Rochester, NY, USAi, using an automatic camera.

\section{Antibodies and reagents}

The following monoclonal and polyclonal antibodies were used in this study:

1. 9D10, a mouse monoclonal antibody to titin [36], obtained from the Developmental Studies Hybridoma Bank, maintained by the Department of Pharmacology and Molecular Sciences, Johns Hopkins University, School of Medicine, Baltimore, MD. USA, and the Department of Biology. Uniwersity of IOwa, IOWa City, IA, USA, under Contract NO1-HD-6-2915 from the NICHD.

2. A mouse monoclonal antibody RV202, specific for vimentin [23].

3. A polyclonal rabbit antiserum (pDes), raised against chicken gizzard desmin [22].

4. An affinity purified polyclonal rabbit antiserum ( $\mathrm{p}$ V/m), raised against bovine lens vimentin [21].

These antibodies to desmin and vimentin are available from Euro-Diagnostics B.V.. Apeldoom. The Netherlands.

5. A mouse monoclonall antibody V9 to vimentin, purchased from Dakopatts,

6. The mouse monoclonal antibody $N B 2$, specific for nebulin [9], purchased from Sigma Chemical Company, St. Louis, MO, USA.

7. A polyclonal rabbit antiserum raised against $a$-actinin, which was a kind gift from Dr. B. Jockusch, Bielefeld, FRG.

8. The mouse monoclonall antibody $M F 2 O$, recognizing all forms of sarcomeric myosin [21. which was a kind gift from Dr. D. Fischman, New York, NY, USA.

9. A mouse monoclonal antibody sr-1, specific for striated muscle $a$-actin [281. which was a kind gift from Dr. G. Gabbiani, Geneva, Switzerland.

10. Rhodamine-labelled phalloidin (Molecular Probes Inc., Eugene, OR, USA) was used for staining of filamentous actin (F-actint.

\section{Cell fractionation, gel electrophoresis, and immunoblotting}

Human skeletal muscle cells, grown in $75 \mathrm{~cm}^{2}$ tissue culture flasks as described above, were collected and the cytoskeletal fraction was prepared as described [27]. Polyacrylamide (PAA) gel electrophoresis of cell fractions enriched for cytoskeletal pr oteins, and staining of the gels, and immunoblotting were carried out essentially as described $[27]$, except that $7 \%$ or $10 \%$ PAA gels were used with a $3 \%$ PAA stacking gel. High- and low-molecular weight markers (Pharmacia LKB Biotechnology AB, Uppsala, Sweden) were used to identify the molecular weight of the separated proteins.

\section{RESULTS}

Characterization of antibody reactivity patterns in human skeletal muscle 


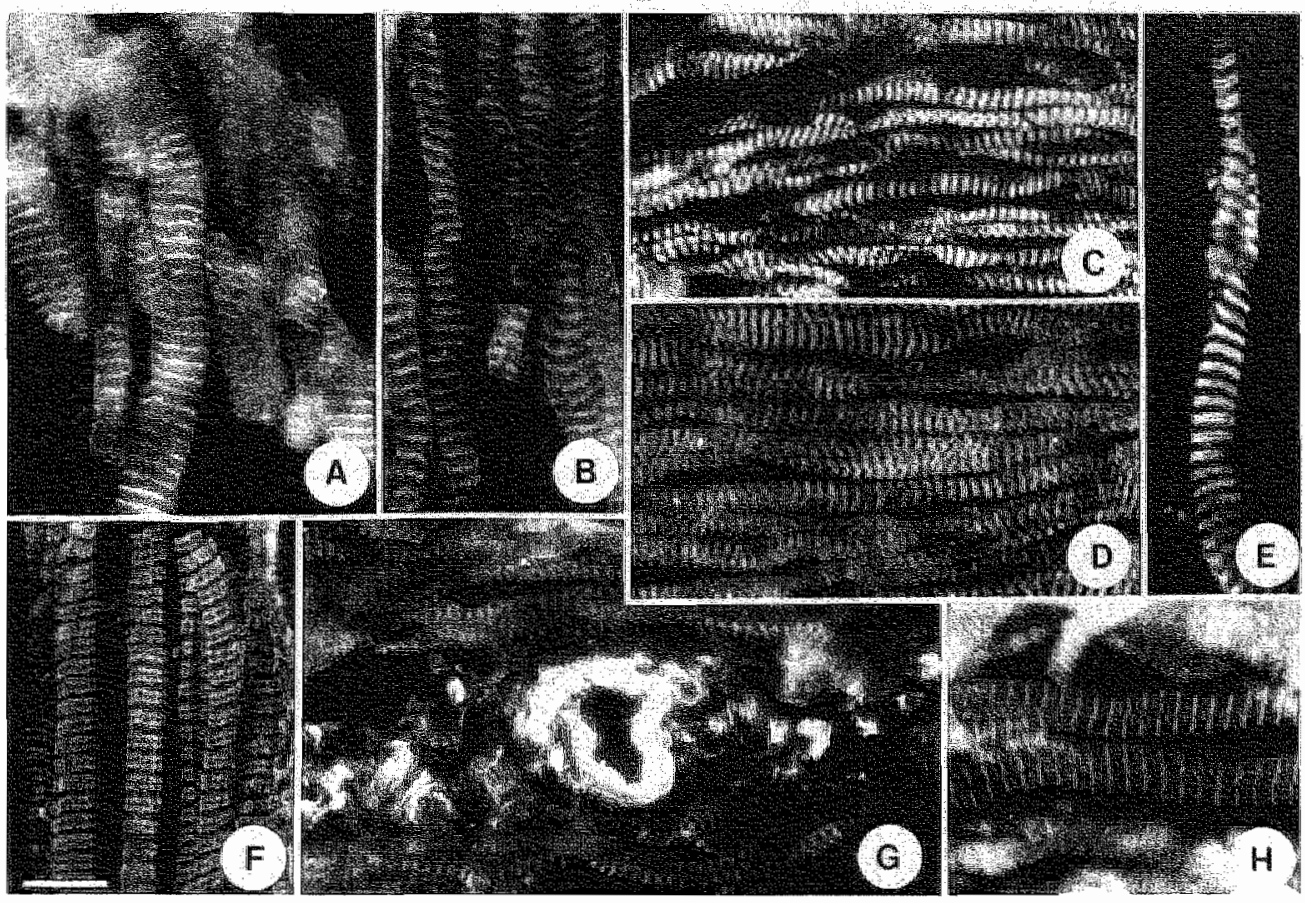

Figure 1: Immunotluorescence micrograpins of neonatal thuman mustle tissue sections incubated with antibodies to $\sigma$-actimin $(A)$, desmin $(B)$, titin $(C, E)$, nebulin $(D)$, myosin $|F|$, and wimemtin $(G)$, or stained with Rhodamine-labelled phalloidin $(\mathbb{H})$. Bar indicates $10 \mu \mathrm{m}$ for $\mathrm{F} ; 13 \mu \mathrm{m}$ for $\mathrm{A}, \mathrm{B}, \mathrm{E} ; 17, \mu \mathrm{m}$ for $\mathrm{C}_{*} \mathrm{D}$, G; $20 \mathrm{~mm}$ for $\mathrm{H}$.
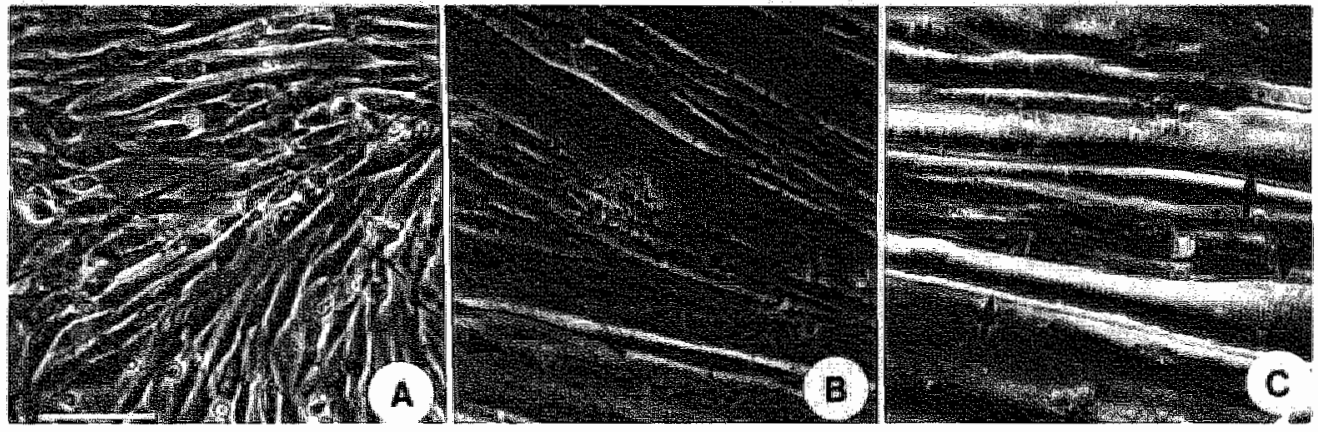

Figure 2: Phase-contrast micrographs of aneurally cultured human shelletal muscle cells. Al Proliferating cells. Bl Young myotubes with predominantly centrally located nuclei (arrowheads). C) Mature. contracting myotubes with cross-striations tarrows) and peripherally located nuclei (arrowheads). Bar indicates $100 \mu \mathrm{m}$ for $\mathrm{A}$ and $\mathrm{B} ; 50 \mathrm{\mu m}$ for $\mathrm{C}$.

Since the specificity of some of the antibodies used was not known for human tissues, the reactivity patterns of the antibodies were established in normal premature human skeletal muscle. Sections of the biopsy material, described above, showed a striated pattern with all the applied antibodies, except for sr-1. The antibodies to a-actinin (Fig. 1A) and desmin (Fig. 1B) showed a discrete striated staining pattern with fluorescence at regular intervals. The titin antibady 9D10 (Fig. 1C. E), the nebulin antibody NB2 (Fig. 1D) 
and the myosin antibody MF2O (Fig. 1F) displayed a doublet banding pattern, the first two antibodies showing discrete lines, and the latter staining a somewhat broader region of the sarcomere. RV202, the monoclonal antibody to vimentin, strongly stained blood vessels and interstitial tissue, and also muscle fibers, resulting in a striation, albeit to a much lesser extent (Fig. 1G). This striated pattern was also seen with $V 9$, a second vimentin monoclonal antibody as well as pVim, a polyclonal antiserum to vimentin inot illustrated). Staining with Ahodamine-phalloidin resulted in a reactivity pattern with alternating strong and weak fluorescent lines (Fig. $1 \mathrm{H}$ ). No clear reactivity was observed with the sr-1 antibody to striated muscle specific $\alpha$-actin. Except for the vimentin antibodies, the reaction patterns were equal to those in adult human muscle (not illustrated).

\section{Muscle cell cultures}

Differentiation of the initial spindlle- to poivgonal-shaped skeletal muscle cells in culture (Fig. 2A) was initiated when the cultures reached confluence, or when the culture medium was changed to a low-nutrition medium. Within 1 day after the change of medium, the cells started to elongate and fused to form syncytia, often with clusters of nuclei (see below). Subsequently these syncytia maturated gradually: long myotubes were formed, nuclei were often translocated from a more central position (Fig. 2B) to the periphery of the myotubes. (Fig. 2B, C). Eventually cross-striations visible with phasecontrast optics developed (Fig. 2C).

\section{Proliferating myoblasts}

The human skeletal musclle-derived cells, grown in high-nutrition culture medium and fixed before reaching confluence, showed a filamentous staining pattern with the desmin antiserum in more than $95 \%$ of the cells (Fig. 3Al, and with the vimentin antibody in virtually all cells (Fig. 3B). A periodically interrupted, stress fiber-like reactivity pattern was observed after an incubation with Rhodamine-phalloidin (Fig. 3C) or the antiserum to a-actinin (Fig. 3D). The antibodies to titin, nebulin, myosin and striated muscle a-actin did not stain the myoblasts.

\section{Non-proliferating, elongated mononuclear cells}

Shortly 19 to 2 days) after the medium change, when the human skeletal muscle cells had elongated, they were tested for the presence of the proteins recagnized by our panell of antibodies and reagents. Longitudinally oriented stress fiber-like structures were stained in a periodically interrupted pattern with the a-actinin antiserum (Fig. 4A) and with Rhodamine-phalloidin (Fig. 4D). A relatively low number of cells showed a similar reactivity with the antibody to striated muscle $\alpha$-actin, accompamied by a diffuse staining of the cytoplasm (Fig. $4 \mathrm{~B}$ ). The reaction patterns of the antibodies to desmin (Fig. 4C) and vimentin (Fig. 4G) remained filamentous. These filaments, however, were ariented more lengthwise. In addition to longitudinally oriented filaments, the antibody to myosin now also stained cytoplasmic spots, which seemed associated with these filaments, often together with a diffuse cytoplasmic staining (Fig. 4E). The antibody to nebulin was negative in these cells (Fig. 4F). The titin antibody showed a diffuse, punctate or filamentous reactivity. These titin reaction patterns will be described below in more extent. The number of cells expressing muscle-specific proteins varied per experiment and was dependent on the exact moment of fixation after the medium change. 

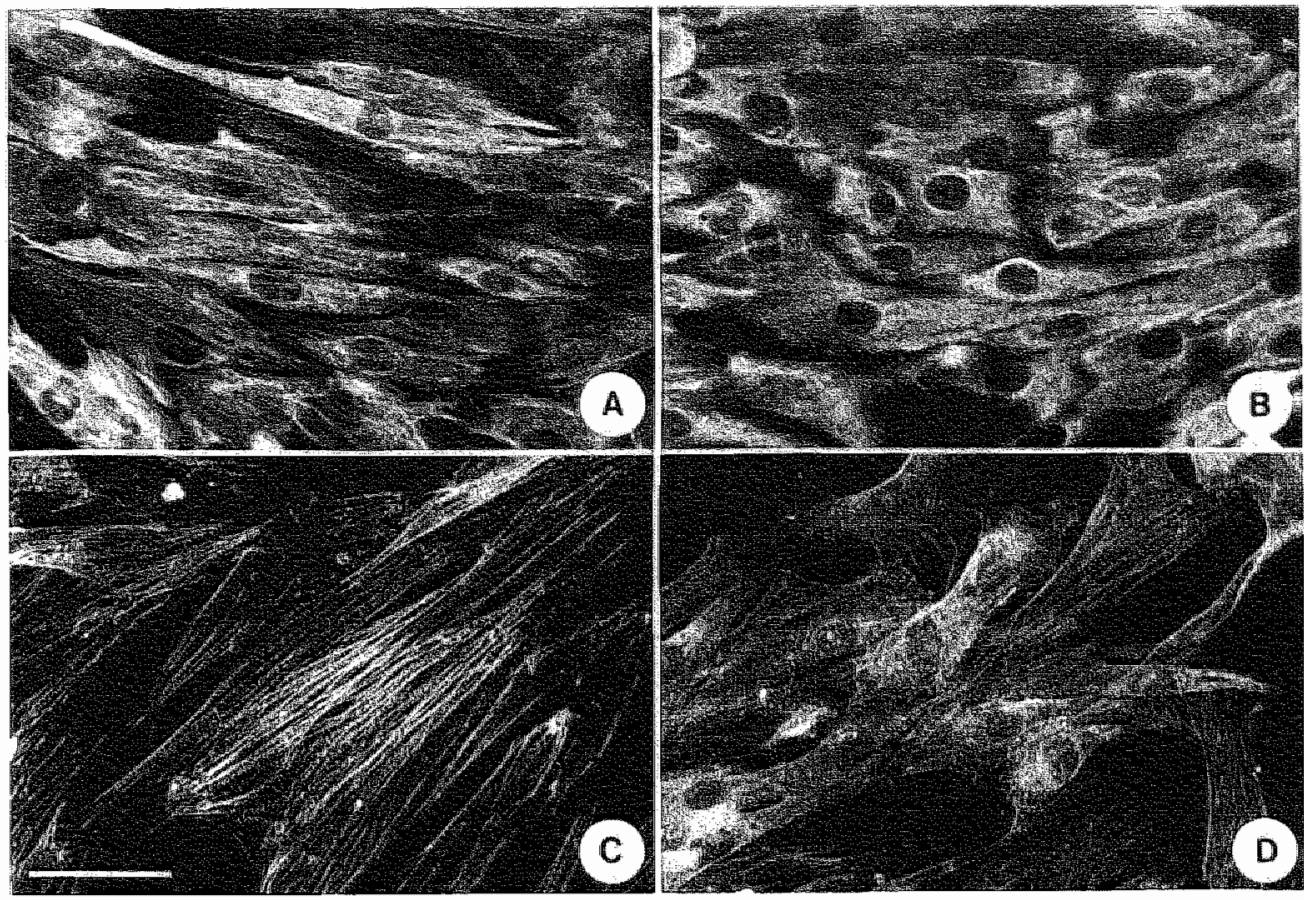

Figure 3: Immunofluorescence micrographs of proliferating human skeletal muscle satellite cells incubated with the antibodies to desmin (A), vimentin [B\}) and a-actinin (D) of stained with Phodaminelabelled phalloidin $(\mathrm{C})$. Bar indicates $75 \mu \mathrm{m}$.

\section{Mature myotubes}

When the human skeletal muscle cells were cultured in low-nutrition medium for 4 to 10 days, the cultures contained numerous long myotubes consisting of fused myoblasts and containing up to 50 nuclei. Most of these myotubes showed cross-striated pattern with the polyclonal antibodies to $\sigma$-actinin $(F i g, 4 H)$. Such a banding pattern was also observed in a majority of the myotubes when F-actin was stained with Rhodamine-phalloidin (Fig. $4 \mathrm{~K}$ ). The monoclonal antibodies to myosin (Fig. 4L), nebulin (Fig. 4M), and titin (see below) now also detected a typical cross-striated distribution pattern for these constituents. Desmin cross-striation was also seen at this stage of myotube differentiation (Fig. 4J), although less frequently than for the other muscle-specific proteins. The antibodies against myosin, titin and nebultin revealed regularly arranged doublet banding patterns, while the antibodies to $a$-actinin and desmin as well as the Rhodamine-phalloidin reagent stained discrete lines with a relatively constant distance. The antibod $y$ to striated muscle $a$-actin showed al staining pattern comparable with that in mononuclear cells. Longitudinally oriented fibrils were stained, while a diffuse reactivity in the cytoplasm was also seen (Fig. 4l). The expression of vimentin as seen with antibody RV202, was dramatically decreased in mature myatubes (Fig. $4 \mathrm{~N}$; arrows).

\section{Titin distribution during several stages of human muscle cell differentiation in culture}

Proliferating human myoblasts were negative for 9010 , the monoclonal antibody to titin. Soon after the change to low-nutrition culture medium, isolated cells that had become 


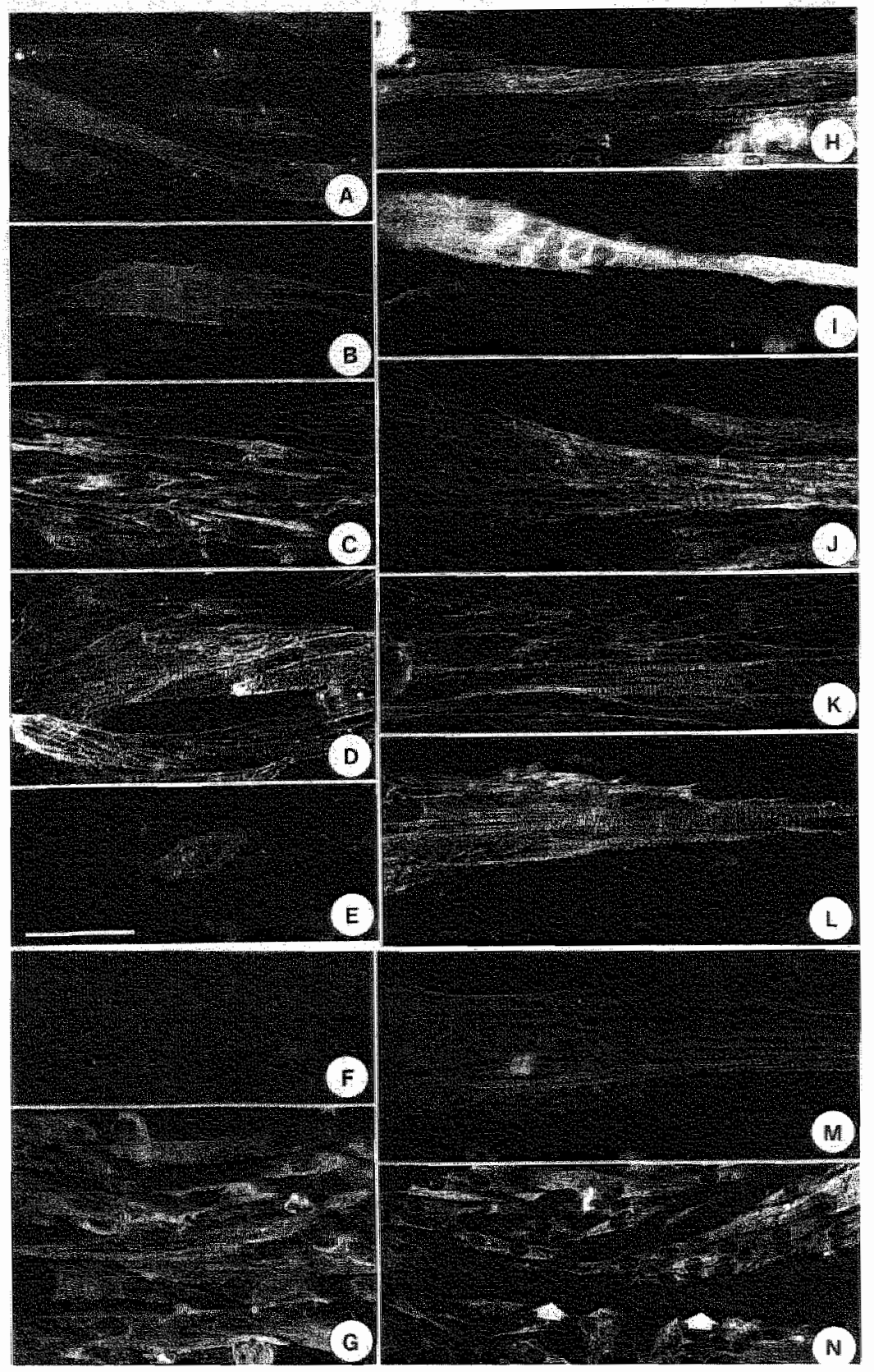

Figure 4: limmunofluorescence micrographs of postmitotic mononucleated myoblaists after change to low-nutrition medum (A-G) and of mature, fused myotubes (H.N) incubated with the antibodies to $a-$ actinin $(A, H)$, striated musclespecitic $a$-actin $\langle B \text {, })_{\text {, desmin }}(C, J)$, myosin $(E, L$, nebulin $(F$, $M)$, and vimentin $1 \mathrm{G} \mathrm{N})$, or stained with Rhodamine-labelled phalloidin $(\mathrm{D}, \mathrm{K})$. Note the vimentin-negative myotube in $\mathbb{N}$ (arrows). Bar indicates $50 \mu m$ for $A \cdot M ; 25 \mu m$ for $N$. 


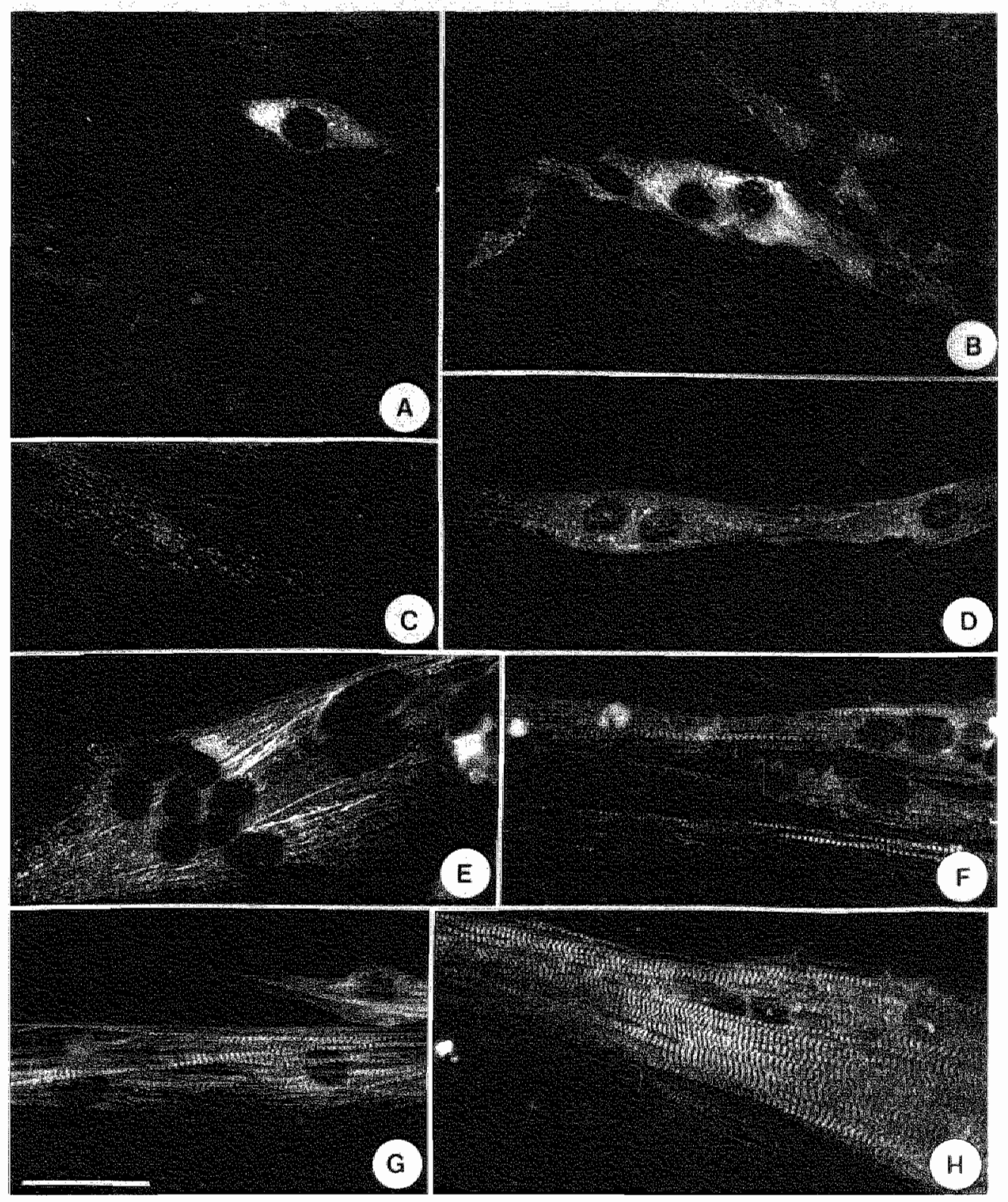

Figure 5: Immunofluorescence micragraphs of different stages of differentiating muscle cells (sed text). incubated with the antibody to titin. Bar indicates $50 \mu \mathrm{m}$ for $A, B, D, F, G, H ; 40 \mu m$ for $C, E$, 
spindle shaped but not yet elongated, showed a diffuse staining pattern including a punctate titin localization in close proximity to the nucleus (Fig. 5A.). In cells aligning prior to tusion. the same reactivity patterns were observed. However, the localization of the spots was more uniformly spread throughout the cytoplasm (Fig. 5B). Following cellfusion these seemed to associate with longitudinally oriented fibrils (Fig. 5C). most probably the stress fibers. A filamentous, stress fiber-like titin reaction pattern was visible in somewhat further differentiated polynuclear cells (Fig. 5D, E). The latter two reactivity patterns were also observed in some elongated mononuclear cells. Subsequently, short stretches of myofibrills developed showing the typical striated doublet staining pattern of titin (Fig. 5F). During further differentiation and growth the number of myofibrils in the myotubes increased (Fig. 5G), aligning and filling most of the cytoplasm, resulting in a reaction pattern more or less comparable with mature myofibers in tissue sections (Fig. 5 HI.

\section{Polyacrylamide gel electrophoresis}

Fractions enriched for cytoskeletal proteins from proliferating human satellite cell cultures and from cultures showing large numbers of maturated myotubes, were fractionated on $10 \%$ polyacrylamide SDS gels. Specific proteins could be identified by their wellcharactenized molecular weights. Cells from proliferating cultures contained relatively small amounts of a-actinin, desmin and actin, while vimentin was present in large quantities (Fig. 6, lane A). Cultures that were differentiated for 6 or 7 days, showed an increased expression of a-actinin and actin. The vimentin:desmin ratio was dramatically decreased, while myosin and tropomyosin were only found in detectable amounts in differentiated cells (Fig. 6, lane B). However, unidentified proteins, exclusively expressed in differentiated cells, were abserved within the stacking gel (not illustrated). Considering that the molecular weights of these proteins exceeded that of myosin by far, we expect them to represent titin and nebulin.

Table 1: Expression pattern of muscle differentiation markers during human myafibrillogenesis.

\begin{tabular}{|c|c|c|c|c|}
\hline $\begin{array}{l}\text { Antibody: } \\
\text { reagent }\end{array}$ & Antigen & $\begin{array}{l}\text { Proliferating } \\
\text { myoblast }\end{array}$ & $\begin{array}{l}\text { Non proliferating, } \\
\text { molongated } \\
\text { myoblasts }\end{array}$ & $\begin{array}{l}\text { Matured } \\
\text { myatubes }\end{array}$ \\
\hline $\begin{array}{l}\text { Polyctomal } \alpha \text {. } \\
\text { actinin }\end{array}$ & a.Actinin & Stress filber-like & Stress fiber-like & Cross-striated \\
\hline$s r-1$ & $\begin{array}{l}\text { Strated muscle } \\
\text { spectfic a-actin }\end{array}$ & Negative & $\begin{array}{l}\text { Diffuse/ } \\
\text { stress fiber-like }\end{array}$ & $\begin{array}{l}\text { Diffused } \\
\text { stress fiber like }\end{array}$ \\
\hline pDes & Dresmin & Filamentous & Filamentous & Cross-striated \\
\hline $\begin{array}{l}\text { Ahodamine- } \\
\text { Phallodin }\end{array}$ & Factin & Stress fiber-like & Stress fiber-like & Cross-striated \\
\hline MF 20 & $\begin{array}{l}\text { Sarcomeric } \\
\text { nyositn }\end{array}$ & Negative & $\begin{array}{l}\text { Diffuse/punctate } \\
\text { Hillamentous }\end{array}$ & Cross-striated \\
\hline NB2 & Nebutin & Negative & Negative & Cross-striated \\
\hline AV 202 & Virmentin & Filamentous & Filamentous & Negative \\
\hline 9010 & Titin & Negative & $\begin{array}{l}\text { Diffuse/punctate/ } \\
\text { filamentous }\end{array}$ & Cross-striated \\
\hline
\end{tabular}



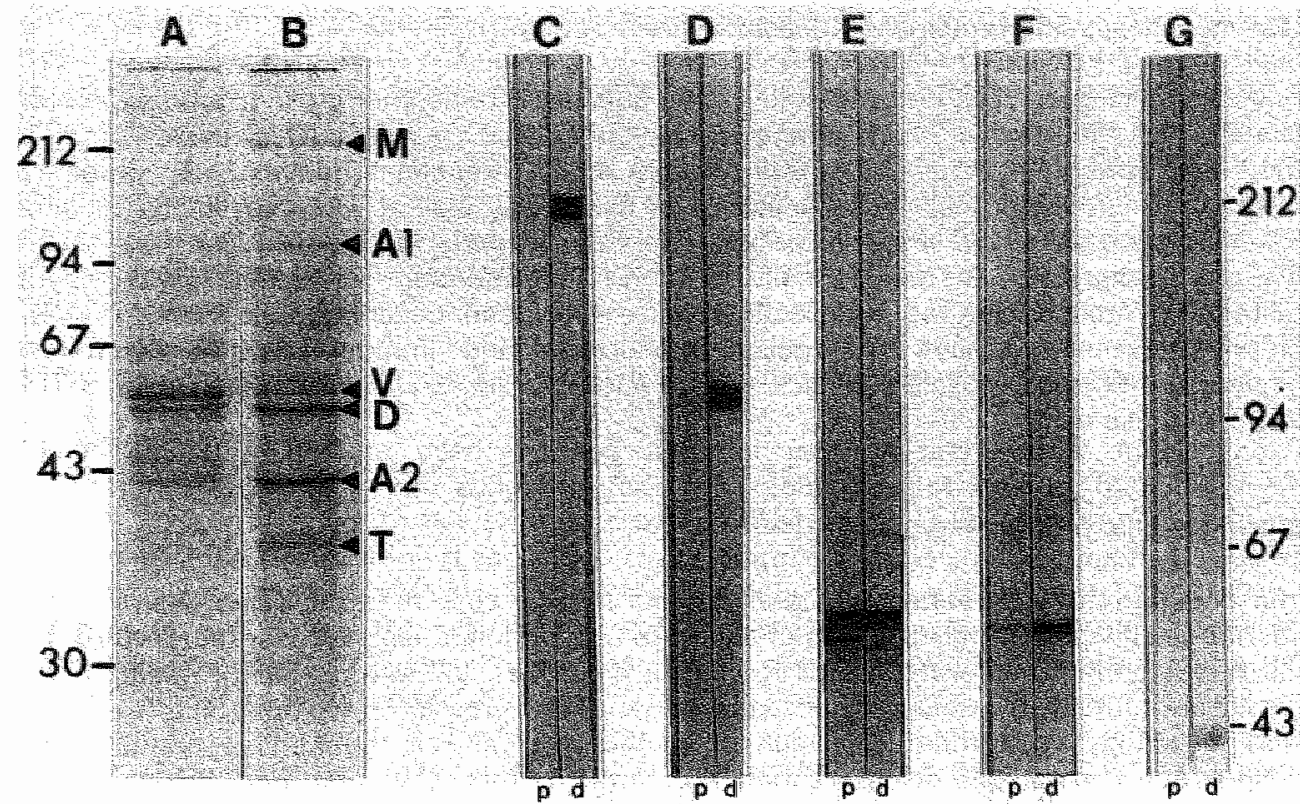

Figure 6: Gel ectrophoresis $(A, B)$ and immunoblotting (C-G) of cytoskeleton-entriched fractions of proliferating (lane $\mathrm{A}$, lanes $\mathrm{Cp}-\mathrm{Gp}$ ) or differentiated llane $\mathbf{B}$, lanes $\mathrm{Cd}$-Gd human skeletal muscle calls. The positions of molecular weight markers for $A$ and $B$ are indicated on the left, and for lanes $C-G$ on the right. Arrowheads point to cytoskeletal proteins identifiable by their molecular weights. M: myosin heawy chain, $200 \mathrm{kDa}$; 1 : a-actinin, $100 \mathrm{kDa}$ : $\mathrm{V}$ : vimentin, $57 \mathrm{kDa}$; D: desmin, $53 \mathrm{kDa}$ : A2: actin, 43 kDa: $T_{\text {: }}$ tropomyosin, $36 \mathrm{kDa}$. Fractionated proteins transferred to nitrocellulose were incubated with

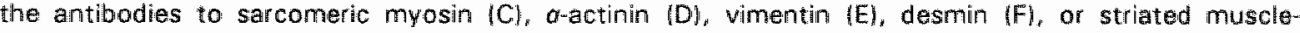
specific aractin $|G|$.

\section{Immunoblotting}

Our results from immunofluorescence studies were confirmed by immunoblotting assays using antibodies to myosin, a-actinin, vimentin, desmin, and striated muscle aractin. Sarcomeric myosin (Fig. 6C), as well as striated muscle a-actin (Fig. 6G) were exclusively detected in differentiated cultures, while an incubation with the antibodies to a-actinin (Fig. 6D) and desmin (Fig. 6F) resulted in significantly stronger reactions in the lanes containing differentiated cells compared to the lanes containing proliferating cells. Vimentin was detected in equal amounts in both stages of differentiation.

\section{DISCUSSION}

In this study we have attempted to answer two main questions: 1) What final stage of differentiation can non-innervated human skeletal muscle cells reach in culture under optimal conditions? This matter was approached by using the expression and organization of certain muscle-specific constituents as markers for certain stages of muscle cell differentiation. 2) How is titin organized during the different stages of in vitro muscle cell differentiation? In particular we were interested in the very first signs of titin expression, its organization at that stage and the further rearrangements up to the fully striated organization. 
Prolferating satellite cells were stained by the antiserum to desmin, as might be expected from the fact that desmin stains activated satellite cells in vivo [12]. This result indicates ethat our cultures contained mainly muscle cells. Desmin-negative cells probably represented fibroblastic cells. The presence of desmin as well as vimentin in the muscle cells is comparable to the in vivo situation where during early stages of myogenesis these UFPs are coexpressed in muscle cells $[3,25]$. The initiation of desmin synthesis in proliferating mouse and rat myoblasts in vitro has been described previously $[1,13]$. Immunofluoresence assays and gelelectrophoresis" and immunoblotting-experiments showed that striated muscle-specific $a$-actin, titin, nebulin, and sarcomeric myosin were absent in these cells.

\section{Muscle-specific protein expression}

After elongation of the cultured human skeletal muscle cells they remained desmin- and vimentin-positive, although the IFP\$ changed to a more longitudinally oriented patterm, as was also seen in "differentiating" BHK-21/C 13 cells [27]. In contrast to titin, sarcomeric myosin and strated muscle-specific a-actin, nebulin expression was not found in these cells, indicating once more that during myogenesis not all myofibrillar proteins are coexpressed at all stages of differentiation in vitro. At this stage and more differentiated stages, we never observed cytoplasmic spots with any antibody except for the titin and myosin antibodies. This indicates that during human myofibrillogenesis, $1-Z-1$ complexes of titin and a-actinin and A-band complexes consisting of myosin and associated proteins [6] do not develop from these spots as observed in chicken skeletal muscle cultures $[30,31]$.

\section{A high degree of maturation of the muscle cell cultures is indicated by desmin cross- striation}

Maturity of the human muscle cell cultures was tested by incubation of the cultures after 4 to 10 days following the change to low-nutrition medium. The process of downregulation of vimentin paralelled by an upregulation of desmin as the main IFP in viva I3, 321 is mimicked in vitro. In the most mature myotubes no vimentin was detected, while desmin showed a cross-striation in varving numbers of myotubes. Howewer, in our cultures no vimentin cross-striation was abserved at any developmental stage isee below). The antibodies to a-actinin, myosin, nebulin and titin, as well as the Rhodaminephalloidin all showed cross-striations. The fact that desmin organized in cross-striations, which was reported earlier to occur only in human skeletal muscle cell cultures when cocultured with neural tissue [19], indicated a high degree of maturity of the myotubes. The altered desmin:vimentin ratio and the upregulation of several muscle prateins could be confirmed by gel electrophoresis and immunoblotting experiments.

\section{Titin expression during human myofibrillogenesis}

In low-nutrition medium the mononuclear muscle cells alter their morphology. The spindleshaped or polygonal cells tend to elongate before fusion and further differentiation. Besides desmin, titin was the only muscle-specific protein detected in non-elongated cells. in a diffuse to punctate pattern. These results confirm observations in skeletal muscle cell cultures derived from other species $[5,13]$ and in vivo studies with embryos from mice $[261$ and rabbits [33]. Titin is one of the first typical myofibrillar proteins expressed in 
differentiating muscle cells. During maturation the spot-like titin reactivity, indicating titin aggregates, changed from a random distribution to a localization associated with fibrits, probably stress fiber-like structures. The latter structures are present during this stage of development as seen with the reagents detecting filamentous actin and the antibodies to a-actinin. Subsequently, the antibodies against titin stained longitudinal fibrils which eventually changed to myofibrils, showing the typical striated titin doublets. After 4 to 10 days in low-nutrition medium, the cultures were occupied by numerous myotubes, showing a mature morphology when stained with the 9010 titin antibody.

\section{Vimentin as constituent of the $\mathbf{Z}$-line region in immature human skeletal muscle}

In our experiments we used autopsy material from a prematurely born boy, to characterize antibodies and reagents for their reactivity patterns in human skeletal muscle. The antibodies to desmin and $a$-actinin stained the $Z$-line region. The titin and nebulin antibodies are known to recognize an epitope around the A-I junction [36] and epitopes within the $\mid$-band $[16]$, respectively. Consequently, doublets of distinct striations were seen. MF20, the antibody to sarcomeric myosin stained A-bands, which alternate with myasin-negative M-lines. Rhodamina-phalloidin stained alternating weak and strong bands, probably representing the thin fillaments and the actin filaments beneath the sarcollemma at the level of the M-line, respectively [7]. Vimentin is normally present in tissues of mesenchymal origin. As a result, our antibodies to vimentin stained vascular endothelium and interstitiall fibroblasts. However, an obvious and significant cross-striated staining reaction was seen in muscle fibers of the immature skeletal muscle. From these findings we can conclude that during human myogenesis vimentin is colocalized with desmin in the Z-line region at least up to 28 weeks of gestation, as was demonstrated also in avian skeletal muscle [111. As already described by Sarnat et al. [25] and Barbet et al. [3], in our hands normal, non-regenerating adult human muscle fibers did not contain detectable amounts of vimentin, while regenerating fibers showed a diffuse vimentin staining pattern. The presence of vimentin in immature (embryonic) human muscle has been shown previously, in a cross-striated fashion, but was never discussed [3]. The absence of vimentin cross-striations in our cultures might be explained by the fact that regeneration, and not embryogenesis, is mimicked in our experiments.

We conclude that cell cultures of human skeletal muscle are an appropriate tool to study virtually all developmental stages of myofibrillogenesis. Desmin cross-striation was described for the first time in aneurally cultured human myotubes, indicating that the culture medium we used enhances inyofibrillogenesis during differentiation. Although cell cultures of human skeletal muscle were per se not always very successful as a model system for studying muscular diseases [20], we feel that these cultures might be useful to study pathogenesis of muscular diseases which are characterized by, or even caused by an abnormal distribution of specific sarcomeric or cytoskeletal constituents 124,29 , 341 .

Acknowledgements: The authors thank H. van der Lee for his major contribution to this work, the staff and co-workers of the Department of Orthopaedy and the Department of Pathology of the University Hospital, Nijmegen for their thelp in obtaining human tissues, and Dr. A. Benders for the preparation of human brain extract.

\section{REFERENCES}

1. Aflen RE, Plankin LL, Greene EA, Boxhorn LK, Johnson SE, Taylor RG, Plerce PR. Desmin is present in proliferating rat muscie satellite cells but not in bovine muscle satellite cells, J. Cell. Physiol. 149, 525-535, 1991 . 
2. Bader $D$, Nasak $r$, Fischman DA. Immunohigtochemical analysis of myosin heavy chain during avian myogenesig in wivo and in witro. A. Cell Bid. $95,763-770,1982$.

3. Barbet JP, Thorrell L.E, Buther-Erowne GS Immunocytochemical characterisation of two generations of fibers during the development of the human quadriceps muscle. Mech. Dev, 35, 311. 1991.

4. Benders AAGM, Van Kuppowet THMSM, Oosterhot A, Veerkamp JH. The biochemical and structural maturation of human skeletal musich cells in culture: the effect of the serum substitute Ultoser G. Exp. Cal Fes. 195, 284-294, $199 \%$.

5. Colky NJ, Tokuyasu KT, Singer SJ. The early expression of myotibritar proteins: in round postrmitotic myoblasts of embryonic skeletal muscie. J. Cell $5 \mathrm{ci} .95,11-22,1990$.

6. Epstein HF. Fischman DA. Molecular analysis of protein assembly in muscla development. Science $251,1039-1044,1991$.

7. Fischman DA. Myotbrillogenesis and the morphogenesis of skeletal muscle. ln Myology. Basic and CWhical. leds. Engel AG, Banker BO) McGraw-Hill, New York, pp 5-30, 1986.

8. Fulton $A B$, lsaacs WB. Tith, a huge, elastic sarcomeric protein with arobabile rale in morphogenesis. Boessays 13,157-161, 1991 .

9. Funst $D O$, Osborn $M$, Nave , Weber $K$. The organization of titin filaments in the half-sarcomere revealed by monoclonal antibodies in immunoelectron microscopy: a map of ten nonrepetitive epitopes starting at the $Z$ lire extends close to the M line. J. Cell Biol. 106, 1563-1572, 1988.

10. Gard OL, Laztides. $E$. The symthesis and distribution of desmin and vimentin during mogenesis in vitro. Cell 19,263-275, 1980

11. Granger BL, Lazarides E. Desmin and wimentin coexist at the periphery of the myofibril $Z$ disc. Cell $18,1053-1063,1979$.

12. Helliwell TR. Gumhan O. Edwards AHT. Lectin binding and desmin expression during necrosis, regeneration, and neurogenic atrophy of human skeletal muscle. J. Pathol. 159,43-51, 1989.

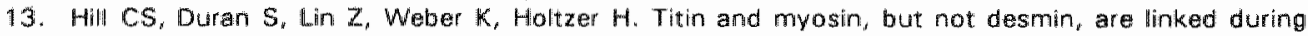
myofibtllogenesis in prostmiktic mononucleated myoblasts. J Cell Biol 103, 2185-2196, 1986.

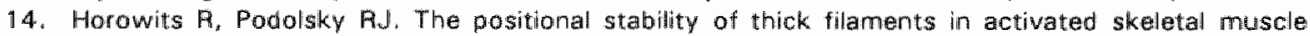
depends on sarcomere length: evidence for the role of titin filaments, J. Cell Bull. 105, 2217. 2223,1987 .

15. Jin JP, Wang K. Cloning, expression, and protein interaction of human nebulin fragments composed of varying numbers of sequence modutes. J. Biol. Chem. 266, 21215-21223, 1991.

16. Kruger M, Wright $J$, Wang Kebulin as a length iregulator of thim filaments of vertebrate skeletal muscles, correlation of thin flament length, nebutin size, and epitope profile. J. Cell Biol. 115, 97-107, 1991.

17. Maruyama K, Natori R, Nanomura $Y$. New elastic protein from muscle, Nature 262, 58-60, 1976.

18. Maruyama $K$, Sawada $H$, Kimura $S$, Ohashi $K$, Hiquehi $H$, Umazume $Y$. Connectin filaments in stretchied skinned fibers of frog skeletal muscle, J. Cell Biol. 99, 1391-1397, 1984.

19. McFerin J. Askanas V. Engell WK. Expression of desimin in human muscle cultured aneurally and innerwated by fetal rat spinal cord neurons labstracth. J. Neurol. Sici. [5uppl] 98, 193, 1990.

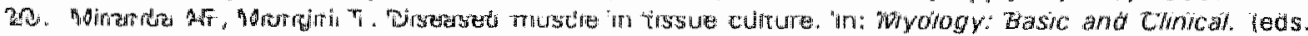
Engel AG, Barker BOI McGiraw-Hill, New York, op 1123-1449, 1986.

21. Fantakers FCS, Puts JJGi, Moesker O, Kant A, Hujismans A, Haag D, Jap PHK, Herman CJ. Vooijs GP. Antibodies to intermediate filament proteins in the immunohistochemical identilication of human tumours: an overview. Histochem. J. 15,691-713, 1983.

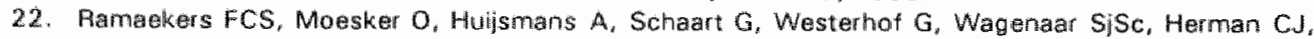
Vooiss GP. Intemediate filament proteins in the study of tumor heterogeneity: an in-depth study of tumors of the urinary and fespiratory tracts. Ann. NY. Acad. Sci. 455,614-634, 1985 .

23. Aamaekers FCS, Huilsmans A, Schaart G, Moesker O, Voolis GP. Tissue distribution of keratin 7 as monitored by a monoulonal antibody. Exp. Cell Res. 170, 235.249, 1987 .

24. Rappaport L, Contard F, Samuel JL. Delcayre C. Marotte F, Tome F, Fardaau M. Storage of phosphoryleted desmin in a famillal myopathy. FEBS Lett. 2, 424-425, 1988.

25. Sarnat HB. Mvotubular myopathy: arrest of morphogenesis of myorilbes associated with persistance of fetal vimentim and desmin. Four cases compared with fetal and neonatal tissue. Can. J.Neurol. Sci. 17.109-123, 1990.

26. Schaart G, Wiebahn C. Lamgmann W, Ramaekers F. Desmin and titin expression in early postimplantation mouse embryos. Development 107, 585-596, 1989.

27. Schaart G. Pleper FA, Kuipers HJH, Bloemendal H. Ramazkers FCS. Baby hamster kidney HBHK. 21 (C 13) cells can express striated muscle tvpe proteins. Differentiation 46, 105-115, 1991.

28. Skall $O$, Gabbiani $G$, Babai $F$, Seemayer $T A$, Pizzolato $G$, Schurch W. Intermediate filament proteins and actin isotorms as markers for soft tissue tumar differentiation and origin. III. 
Rhabdomyosarcomas. Am. J. Pathol. 130,515-531, 1988.

29. Thomell L-E. Eriksson A, Edstrom L. Intermediate fhanmen in human myopathes. Hin: Can and Musche Motihty. Vol. 4 leds. Dowben AN, Shay JWh Plenum Press, New York, po 85-136, 1983.

30. Tokuyasu KT. Maher PA. Immunocytochemical studies of cardiac myolborllogenesis in early chick embryos. 1. Presence of immunofluorescent titin spots in premyotiburil stages. J. Cell Biol. 105. $2781-2793,1987$

31. Tokuyasu KT, Maher PA. Immunocytochemica studies of cardiac myotibrillogenesis in early chick embryas. II. Generation of a-actinin dots within titin spots at the time of the first myofibril formation. J. Cell Biol. 105, 2795-2801, 1987.

32. Tokuyasu KT, Maher PA, Singer S.J. Distributions of vimentin and desmin in developing chick myotubes in wivo. I. Immunofluarescence study. J. Cell Biol. 98, $1961 \times 4972,1984$.

33. Van der Loop FTL, Schaart $G_{i}$ Langmann W, Ramaekers FCS, Viebahn Ch. Expression and organization of muscle specific proteins during the early developmental stages of the rabbit heart. Anat. Embryol. 185, 439-450, 1992.

34. Van der Ven PFM, Jap PHK, Wetzels RHW; Ter Laak Hd, Ramaekers FCS, Stadhouders AM, Sengers RCA. Postnatal centralization of muscle fibre nuclei in centronuclear myopathy. Neuromusc. Disorders $1,211 \cdot 220,1991$.

35. Wang K, Ramirez-Mitchell R. Identification of an N2-line protein of striated muscle. Proc. Nat. Acad. Sci. USA 77, 3254*3258, 1980.

36. Wang SM, Greaser ML. Immunocyochemical studies using a monoclonal antibody to bowine cardiac titin on intact and extracted myofibrils. J. Muscle Res. Cell Motil. 6, 293-312, 1985.

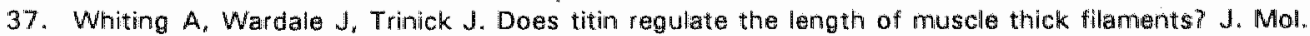
Biol. 205, 263-268, 1989.

38. Yasin $R$, Van Beers $G$, Nusse KSE, Al-Ani $S$, Landon DN, Thompson EJ. A quantitative technique for growing human adult skeletal muscle in culture starting from mononucleate cells. J. Neurol. Sici. $32,347-360,1977$. 



\section{CHAPTER 4}

\section{CHARACTERIZATION OF CARDIOTIN, A STRUCTURAL COMPONENT IN THE MYOCARD}

G. SCHAART, P.F.M. VAN DER VEN and F.C.S. RAMAEKERS

European Journal of Cell Biology 62, 34-48, 1993 


\section{ABSTRACT}

The characterization and subcellular distribution of cardiotin, a structural component of striated muscle, is described using a monoclonal antibody. This high molecular mass component $(>300 \mathrm{kDa}$ ) is expressed in the myocard of several species and to a lesser extent also in skeletal muscle. Cardiotin is not lound in smooth muscle tissues, other mesenchymal or epithelial tissues. The cardiotin distribution pattern is independent of other sarcomeric components, such as desmin, myosin, actin, titin, nebulin, and desmoplakin, and shows a longitudinal filamentous localization between myofibrils. The average distance between parallel running cardiotin filaments is approximately $2.3 \mathrm{\mu m}$, as concluded from confocal scanning laser microscopic anaiysis of double-immunolabelled muscle prepairations. The cardiotin fllamentous staining reaction is ariented perpendicularIy to the typlcal cross-striations observed with antibodies to desmin, spanning several sarcomeres and showing a length between 12 to $80 \mathrm{pm}$ in frozen sections. Its localization pattern suggests a possible link with the sarcoplasmic reticulum. We have never observed cardiotin filaments to cross the intercalated discs, stained by antibodies to desmoplakins or desmin. Cardiotin cannot be solubilized from cardiac muscle by nonionic detergents or thigh concentrations of $\mathrm{KCl}$ or $\mathrm{KI}$, suggesting a structural role in the myocard. The protein could sofar not be detected in developing embryonic heart, but expression seems to be initiated after birth, depending on the species examined.

\section{INTRODUCTION}

The expression of specific proteins can distinguish the different stages of muscle cell differentiation during myofibrillogenesis and cardiogenesis in vivo and in vitro $12,6,13$, $19,21,44,45,55,56,63$ ). Over the past two decades many of such specific structural muscle components and their functions have been described [For reviews see: 1, 4, 5, 5.41 .

Amongst these constituents are the intermediate filament proteins desmin and vimentin, which are inversely regulated in both smooth muscle cells and striated muscle cells 13. 29,491 . In adult striated muscle desmin is found in the $Z$-ine 1171 where it maintains the proper alignment of myofibrils during contraction and relaxation [6, 30]. Vimentin is normally found in early stages of muscle cell differentiation and can coexist or even copolymerize with desmin $[10,39,48,51]$. At certain stages of development of the theart of the mouse and the rabbit even cross-striations of vimentin have been described 144, 55,581 . Vimentin is also found in a cross-striated pattern in human cultured muscle cell lines [56]. During further stages of myotube formation, wimentin expression is downregulated both in vitro and in wivo $[114,38,44,561$.

Different isoforms of actin. myosin and tropomyosin are expressed during muscle cell development $[1,2,6,31,32,63,65]$. Until now the functional significance of expressing such different protein isoforms during different stages of muscle development is not clearly understood [1].

A protein only found in skeletal and cardiac muscle cells is titin, with an extremely high molecular mass of $3.10^{6}$ Dalton $[20,591$. Titin, also known as connectin 1351 , is localized between the $M$ - and $Z$-lines $[6,12,13,66]$ and is assembled in its mature pattern earlier than other major contractile proteins $[19,44,45,52,551$. According to Whiting et al. [66] and Trinick [54] a part of the titin sequence, i.e., the part associated with the Z-line, has elastic properties, thus preventing the sarcomere from overstretching. The other region of the molecule seems to regulate the assembly of myosin and other thick filament proteins $\llbracket 22,54 \rrbracket$.

Another giant muscle protein is nebulin 1601 with a molecular mass of approximately $8.10^{5}$ Dalton 150, 541. Nebulin, only found in skeletal muscle and not in heart muscle or smooth muscle cells, is an inextensible filamentous protein 1611 that appears to be 
associated with the thin filaments, but not with titin $[36,611$, and has been suggested to regulate actin assembly $[23,25,26]$.

Only recently the biogenesis and organization of the membrane systems in striated muscle cells have received renewed attention. In particular studies on the regulation of excitation-contraction coupling upon differentiation of the muscle calls have led to the generation of several probes for proteins involved in this process $[7,8]$.

We have detected a new structural muscle cell constituent with a high molecular weight, and a specific distribution pattern in striated muscle, particularly in the myocard. It was characterized by a monoclonal antibody [46] and designated cardiotin. Here we describe the tissue and species distribution patterns of cardiotin, its subcellular localization in muscle cells and its relation to other muscle cell components.

\section{MATERIALS AND METHODS}

\section{Tissue distribution}

Normal adult human tissues obtained by autopsy, i.e., heart iventricle and atrium, both right and lieft; apex), skelletal muscle, tongue, esophagus, stomach, small intestine, collon, liver, bille bladder, kidnev, urine bladder, prostate, ovary, uterus, breast, lung, pancreas, lymphe fallicle, spleen, and brain were immediately frozen in liquid nitrogen $\left(\mathbb{N}_{2}\right)$.

Heart tissue of a 16-week-old human embryo was obtained during autopsy and immediately frozen in liquid $\mathrm{N}_{2}$.

From different animals i.e.. Xenopus laevis, chicken, mouse, rat hamster, rabbit, cat. dog, goat, cow, and Rihesus monkey, heart tissue (myocard), tongue, small intestine, and skeletal muscle were stored in liquid $\mathrm{N}_{2^{n}}$

All the tissues were mounted in Tissue-Tek. (OCT-compound; Miles Inc., Elkhart, IN, USA) and $5 \mu \mathrm{m}$ sections were cut at $-25^{\circ} \mathrm{C}$ and air-dried overnight at room temperature.

\section{Antibodies}

Antibodies used in this study are:

1. The monocional R2G antibody to cardiatin (IgM), obtained as follows: chicken gizzard desmin (for purification method see [41, 42]) was used for the immunization. A female Balb/C mouse was immunized twice intraperitoneally and three times intravenously with approximately $75 \mu \mathrm{g}$ purified chicken gizzard desmin in $250 \mu$ phosphate-buffered saline (PBS: $137 \mathrm{mM}$ sodium chloride $(\mathrm{NaCl}$; Merck, Darmstadt, FRG), $13 \mathrm{mM}$ di-sodium hydrogen phosphate dihydrate $\left(\mathrm{Na}_{2} \mathrm{HPO}_{4} \cdot 2 \mathrm{H}_{2} \mathrm{O}\right.$; Merck), 3 $\mathrm{mM}$ potassium dihydrogen phosphate $\left(\mathrm{KH}_{2} \mathrm{PO}_{4}\right.$; Merck), $\left.\mathrm{pH} 7.4\right)$. After the immunization period ( 3 weeks), the mouse was killed, and spleen cells were fused with $S p 2 / 0$ Ag14 myeloma cells, cloned and grown according standard protocols [24, 45]. The monoclonal antibody $R 2 G$ was selected on basis of its strong reactivity pattern with human cardiac muscle, whille other cell types were not stained, except for a relatively weak reaction with skeletal muscle.

2. A mouse monoclanal antibody (RD301]) to desmin [40,44].

3. A mouse monocllonal antibody (RV 203) to vimentin [45].

4. Dp1\&2-2.15, a mouse monoclonal antibody to desmoplakin (Progen Biotechnik $\mathrm{GmbH}$. Heidelberg, FRG) [11].

5. DE-R-11, a mouse monoclonal antibody to desmin (DAKOpatts, Glostrup, Denmark) [3].

6. A polyclonal rabbit antiserum to chicken gizzard desmin (pDes) [43].

7. An affinity-purified polyclonal rabbit antiserum to titin (kind gift from Dr. D. Gassner, Bonn, FRG) [15, 44]. 
8. A mouse monoclonal antibody $(9010)$ to titin $[18,62]$.

Both antibodies to titin gave exactly the same staining patterns when tested on human striated muscle tissues. Both are negative in non-striated muscle tissue.

9. A mouse monoclonal antibody (MF20) to sarcomeric lembryonic and adult) myosin (2).

10. M3F7, a mouse monoclonal antibody to type [V collagen [9].

Monoclonal antibodies 9010, MF20, and M3F7 were obtained from the Developmental Studies Hybridoma Bank, maintained by the Department of Pharmacology and Molecular Sciences, Johns Hopkins University School of Medicine, University of llowa, lowa City, IA, USA, under contract NO1-HD-6-2915 from the NICHD.

\section{Immunocytochemistry}

In this study indirect immunofluorescence assays were performed. In all cases $5 \mu \mathrm{m}$ thick cryostat sections, obtained from freshly frozen tissues were used. The sections were treated routinely for 5 min with $0.5 \%$ Triton $X-100$ (BDH Chemicals Ltd., Poole, UK) in PBS, followed by a PBS washing step for 5 min.

Alternative pretreatment of the tissue sections with $0.5 \%$ Triton X-100 in PBS containing either $0.6 \mathrm{M}$ potassium iodide ( $\mathrm{KI}$; Merck) and $1 \mathrm{M}$ potassium chloride ( $\mathrm{KCl}$; Merck), or with $0.5 \%$ sodium deoxycholate (NaDOC; Merck) and 1\% Twoen 40 (Sigma Chem. Co, St. Louis, MO, USA) was applied for 5 min, followed by a PBS washing step for $5 \mathrm{~min}$.

Parallel fresh cryostat sections were directly fixed for 5 min in methanol $\left(-20^{\circ} \mathrm{C}\right.$; Merck), then for $1 \mathrm{~min}$ in acetone $\left(-20^{\circ} \mathrm{C}\right.$; Merck) and air-dried.

Tissue sections (see: Tissue distribution) of different species (i.e., Xenopus laevis, chicken, mouse, rat, rabbit, hamster, cat, dog. goat, cow, Rhesus monkey and man), pretreated with $0.5 \%$ Triton $X-100$ were incubated with the primary antibody for 30 min at room temperature, followed by a washing step with PBS. For the second incubation step the appropriate fluorescein isothiocyanate. (FITC) conjugated antibody (goal antimouse IgG or goat anti-mouse IgM: both from Southern Biotechnology Associates (SBA) Inc. Birmingham, Alabama, USA) were used. For double-labeling studies Texas Red- (TR) conjugated antibodies (goat anti-mouse IgM or goat anti-mouse IgG1; SBA) were used. The secondary antibodies were applied for $30 \mathrm{~min}$ at room temperature. After three washing steps with PBS, the immunofluorescent-stained tissues were mounted in Mowiol (Hoechst, Frankfurt, FRG) [37].

Proliferating and differentiating human skeletal muscle cell cultures were grown on glass coverslips (for method see: [56]). Differentiation of the human skeletall muscle cells was initiated by a medium-switch from a high-nutrition medium to a low-nutrition medium (45, 561.

Cytospins were made from isolated rabbit cardiomyocytes (for method see: [57]) in PBS containing $20 \%$ fetal calf serum $15 \mathrm{~min}, 800 \mathrm{rpm}$ in a Shandon Cytospin 3; Shandon Scientific Ltd., Astmoor, Runcorn, UK).

Indirect immunofluorescence assays on cultured human skeletal muscle cells and isolated rabbit cardiomyocytes were performed as described above.

\section{Confocal scanning laser microscopy (CSLM)}

Immunostained adult human myocard was observed with a Bio.Rad MRC-600 confocal scanning laser microscope (CSLM: Bio-Rad Laboratories, Richmond, CA, USA), equipped with a Crypton/Argon mixed gas laser (Ion Laser Technology, Salt Lake City, UT, USA) with two separate wavelengths for the excitation of fluorescein isothiocvanate (FITC, $488 \mathrm{~nm}$ ) and Texas Red (TR, $568 \mathrm{~nm}$ ) and a Zeiss Axiophot microscope. To quantitate fluorescence intensities, fluorescein-labelled cryostat sections $(5 \mu \mathrm{m}$ thick $)$ of human 
myocard were excitated with a single wavelength light beam of $488 \mathrm{~nm}$, using a neutrall density filter no. 1.5. showing $3 \%$ transmission and a fixed pinhole position. Image processing was performed to upscale the signal and obtain optimal contrast. Photographs were taken from the monitor with a Nikon camera using a Kodak Ektachrome film with a setting of 400 ASA.

\section{Gell electrophoresis and immunolblotting}

Several procedures were applied to obtain cytoskeletal preparations from human heart muscle. Approximately 40 cryostat sections $(20 \mu \mathrm{m}$ thick) of fresh frozen human heart tissue were collected and washed with $1 \mathrm{ml}$ PBS and centrifuged for 5 min at 12,000xg. After centrifugation the pellet was subjected to a number of different extraction steps:

1. Triton $X-100$ extraction: after the PBS wash the pellet was suspended in $1 \%$ Triton $X$. 100, $5 \mathrm{mM}$ ethylenediaminetetra acetic acid (EDTA; Merck), $0.4 \mathrm{mM}$ phenylmethylsulfonyl fluoride (PMSF; Merck] in PBS, pH 7.4 [45], and extracted for $5 \mathrm{~min}$ on ice. After centrifugation for $5 \mathrm{~min}, 12,000 \times \mathrm{g}$, the pellet was washed in $1 \mathrm{ml} \mathrm{PBS}$. After a final centrifugation step $(5 \mathrm{~min}, 12,000 \times \mathrm{g})$, the cytoskeletal preparation was dissolved by boiling for $4 \mathrm{~min}$ in SDS-sample buffer [28], containing $2.3 \%$ sodium dodecylsulfate (SDS; BDH Chemicals Ltd.) and 5\% B-mercaptoethanol (Bio-Rad Labora-tories).

In parallel with the Triton-extraction, tissue sections were extracted with $1 \%$ Triton $X$ 100 in PBS containing $0.025 \%$ DNAse (Sigma) or $0.001 \%$ trypsin (Flow Laboratories, Irvine, UK; described by Gerdes et al. [16]). After treatment for 5 min with DNase or trypsin the samples were washed with PBS and dissolved in SDS-sample buffer.

2. KI/KC/extraction: the pellet was homogenized and extracted for $5 \mathrm{~min}$ on ice in $1 \mathrm{ml}$ $0.6 \mathrm{M} \mathrm{KI}, 1 \%$ Triton $X-100,5 \mathrm{mM}$ EDTA, and $0.4 \mathrm{mM}$ PMSF in PBS, pH 7.4. After centrifugation $(5 \mathrm{~min}, 12,000 \times \mathrm{g})$ the pellet was suspended and extracted for $5 \mathrm{~min}$ in 1 $\mathrm{M} \mathrm{KCl}, 1 \%$ Triton $X-100,5 \mathrm{mM}$ EDTA, $0.4 \mathrm{mM}$ PMSF in PBS, pH 7.4. Finally the pellet $(5 \mathrm{~min}, 12,000 \mathrm{xg})$ was washed in $1 \mathrm{ml}$ PBS and dissolved in SDS-sample buffer.

3. NaDOC/Tween 40 -extraction: after the first: PBS washing step, the pellet was extracted for $5 \mathrm{~min}$ in $0.5 \% \mathrm{NaDOC}, 1 \%$ Tween $40,5 \mathrm{mM}$ EDTA and $0.4 \mathrm{mM}$ PMSF in PBS, pH 7.4, followed by a PBS washing step and addition of SDS-sample buffer.

For one-dimensional SDS-gel electrophoresis (SDS-PAGE) using a Mini Protean II Electrophoresis Cell (Bio-Rad Laboratories) and immunoblotting using a Mini Trans-Blot Electrophoretic Transfer Cell (Bio-Rad Laboratories) polyacrylamide slab gels containing $0.1 \%$ SDS [28] were loaded with the cytoskeletal samples, prepared as described above. After electrophoretic separation, the proteins were stained with Page Blue 83 (BDH Chemicals L.td.) or subjected to immunoblotting.

The separated polypeptides were transferred to a nitrocellulose membrane (Filter BA 85 , Schleicher and Schuell, Dassel, FRG) by blotting for $1 \mathrm{~h}$ at $100 \mathrm{~V}$ in a cold $\left(4^{\circ} \mathrm{C}\right)$ buffer containing $25 \mathrm{mM}$ Tris (Merck), $192 \mathrm{mM}$ glycine (Merck), 0.02\% SDS [45, 53). No methanol was used for immunoblotting.

For detection of cardiotin with monoclonal antibody $R 2 G$ the chemiluminescence method was used. After protein transfer, the nitrocellulose sheet was preincubated for $1.5 \mathrm{~h}$ in $3 \%$ bovine serum albumin (BSA; Sigma), $350 \mathrm{mM} \mathrm{NaCl}$, and $10 \mathrm{mM}$ Tris-HCl, $\mathrm{pH} 7.6$. Culture supernatant of the primary monoclonal antibody $R 2 G$ was $1: 5$ diluted and incubated overnight at room temperature in $0.3 \%$ BSA, $150 \mathrm{mM} \mathrm{NaCl}$. $1 \%$ Triton $X-100$, $0.5 \% \mathrm{NaDOC}, 0.1 \%$ SDS and $10 \mathrm{mM}$ Tris-HCl pH 7.6, followed by washing steps $(3$ times 10 min) with TP-buffer: $0.5 \%$ Triton $X-100$ in PBS. Thereafter, the blots were incubated with horseradish peroxidase-conjugated rabbit anti-mouse IgM (DAKOpatts) for $1 \mathrm{~h}$ at a dilution of 1:500. The blots were washed for $2 \mathrm{~h}$ in TP-butfer and treated for 1 min with the chemiluminescence fluid ECL (Amersham international pcl. Amersham. UK). Finally a Fuji medical X-ray film RX (Fuji Photo Film Co. Ltd. Japan) was exposed to the nitrocellulase sheets for 30 sec to $5 \mathrm{~min}$. 
For the detection of other muscle antigens, the nitrocellulose sheets were preincubated for $1 \mathrm{~h}$ at room temperature with $0.05 \%$ Tween 20 (Sigmal in PBS. All antisera were diluted in $0.05 \%$ Tween 20 PPBS, that was also used for all washing steps. Primary antibody incubations were carried out overnight. After three washing steps leach 10 min), horseradish peroxidase-conjugated rabbit anti-mouse Ig (DAKOpatts) was applied for $1 \mathrm{~h}$ at room temperature in a 1:400 dilution. The blots were washed again three times for 10 min and at least one time with PBS for 5 min, followed by detection of peroxidase with 4-chloro-1-naphtol (Merck) and $0.12 \%$ hydrogen peroxide (Merck) in PBS. The blots were then rinsed with tap water for $5 \mathrm{~min}$ and air-dried. Immunostained blots could be reincubated one or two times with other primary antibodies [45].

\section{Metabolic labelling and immunoprecipitation}

Human satellite cells were enzymatically isolated from normal adult human skeletal muscle, grown, trypsinized and frozen as described before $156 \mathrm{l}$. In our experiments, cells were quickly thawed and plated in culture dishes $1 \varnothing=60 \mathrm{~mm}$; Greiner, Frinkenhausen, FRG) in a culture medium consisting of Dulbecco's modified Eagle's medium (DMEM; Sigma) supplemented with $20 \%$ fetal calf serum (FCS, Gibco BRL, Paisley, UK), $2 \%$ chick embryo extract (Flow Laboratories). $2 \mathrm{mM}$ glutamine (Gibco BRL), $100 \mathrm{U} \cdot \mathrm{ml}^{-1}$ penicillin (Gibco BRL) and $1 \mu \mathrm{g} \cdot \mathrm{ml}^{-1}$ streptomycin (Gibco BRL). When cells were grown to near confluency, they were cultured for $1 \mathrm{~h}$ in $1 \mathrm{ml} / \mathrm{dish}$ methionine free DMEM (Sigma) supplemented with $20 \%$ dialyzed FCS, glutamine and antibiotics as above. Subsequently $100 \mu \mathrm{Ci}\left[{ }^{35} \mathrm{~S}\right]-m e t h i o n i n e$ (Tran $\left[{ }^{35} \mathrm{~S}\right.$ ]-Label, ICN Radiochemicals, Irvine, CA, USAl was added per dish. After 16 to $20 \mathrm{~h}$ the dishes were washed three times with cold PBS and the cells were collected in $0.1 \mathrm{M} \mathrm{Na}_{2} \mathrm{HPO}_{4}$ (Merck). $0.2 \% \mathrm{BSA}, 0.1 \%$ Na-azide (Merck) and $1 \%$ Triton $X-100$ using a rubber policeman. SDS and $B$-mercaptcethanol were added to $2 \%$ and $1 \%$ respectively, the samples were heated for $10 \mathrm{~min}$ at $90^{\circ} \mathrm{C}$ and centrifuged for $15 \mathrm{~min}$ at $12,000 \times \mathrm{g}$. The supernatants were collected, 4 volumes of 6 IMM EDTA, $190 \mathrm{mM} \mathrm{NaCl}, 2.2 \%$ Triton $X-100$, and $50 \mathrm{mM}$ Tris- $\mathrm{HCl}, \mathrm{pH} \mathrm{7.4}$, and $50 \mu l$ protein A-sepharose CL-4B (Pharmacia, Uppsala, Sweden, 1:1 in PBS) were added. This mixture was incubated for $4 \mathrm{~h}$ at room temperature and centrifuged for 15 min at $1,000 \times \mathrm{g}$. Supernatants were collected and incubated for $16 \mathrm{~h}$ at $4{ }^{\circ} \mathrm{C}$ with $200 \mu \mathrm{l}$ tissue cuiture supernatants of R2G or an other unrelated $\mathrm{lgM}$ mouse monocional antibody. As mouse lgM do not bind to protein $A$, a two step procedure was necessary, and $5 \mu$ rabbit anti-mouse $\lg M\left(0.5 \mathrm{mg} \cdot \mathrm{ml}^{*}\right.$, Zymed, San Fransisco, CA, USA) was added. After an incubation for $2 \mathrm{~h}$ at room temperature. 0.1 volume protein A-sepharose CL-4B was added and the samples were again incubated for $1 \mathrm{~h}$ at room temperature. The protein Asepharose was collected by centrifugation and washed 5 times with $0.5 \mathrm{M} \mathrm{NaCl}, 50 \mathrm{mM}$ Tris $+\mathrm{HCl}$ pH 7.4, $1 \%$ Triton $X-100,0.1 \%$ SDS, $15 \mathrm{mM} \mathrm{B-mercaptoethanol,} \mathrm{and} 5 \mathrm{mM}$ EDTA. After the last washing step, $25 \mu /$ SDS-sample buffer was added to the pellet, the samples were boiled for $10 \mathrm{~min}$ and electrophoresed on a $10 \%$ polvacrylamide gel containing $0.1 \%$ SDS using a Mini Protean II Electrophoresis Cell (Bio-Rad Laboratories). Gels were dried using a Bio-Rad 543 gel drver and exposed to Kodak X-OMAT AR film (Eastman Kodak Company, Rochester, NY, USA) for 6 days.

\section{RESULTS}

The newly developed monoclonal antibody R2G was characterized in immunohistochemical assays and by immunoblotting. The double-labelling immunofluorescence technique, combining R2G with several antibodies to muscle-specific constituents, was used on cryostat sections of normal tissues in order to establish the tissue distribution and subcellular localization of the protein recognized by this antibody. The newly characteri- 

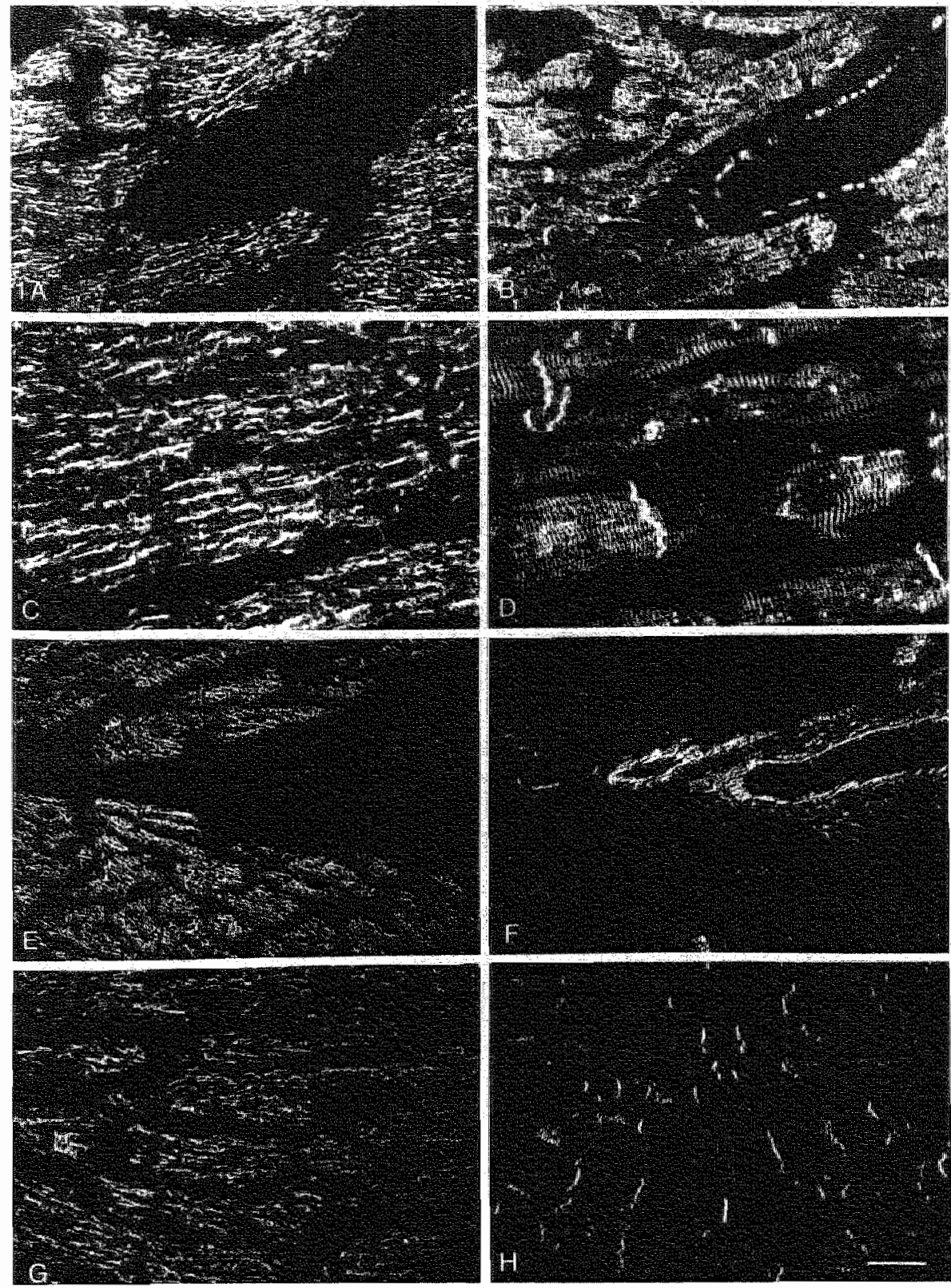

Figure 1: Double-label immunofluorescence microscopy of adult human heart tissue sections incubated with the monocional antibodly to cardiotin $(R 2 G ; A, C, E, G)$, and with antibodies to desmin (DE-R-11 and RD301; B, D, respectively), vimentin (RV203; $F$ ) and desmoplakins 1 and 2 (Dp 1\&2-2.15; H). Note that smooth muscle structures of blood vessels do not stain with the cardiotin antibody $(A, E)$ in contrast to the desmin $[\mathrm{B}$ ) and vimentin $[F]$ antibodies. Bar indicates $20 \mu \mathrm{m}$ for $\mathrm{C}, \mathrm{D} ; 40 \mu \mathrm{m}$ for $\mathrm{A}, \mathrm{B}$, $\mathrm{G}, \mathrm{H} ; 80 \mathrm{\mu m}$ for $\mathbb{E}, \mathrm{F}$. 
Zed protein is designated cardiotin. because it is mainly restricted to cardiac striated muscle $[46,47]$.

\section{Distribution of cardiotin in human tissues}

The monoclonal antibody $\mathrm{R} 2 \mathrm{G}$, from here on designated as anti-cardiotin, reacts strongly with adult human heart muscle cells and to a lesser extent with human skeletal muscle cells. A fibrillar reaction pattern was observed between the myofibrils of the heart cells (Fig. 1A, Cl. The typical cardiotin staining pattern was observed in different regions of the adult human heart i.e., the right and left ventricle and the right and left atrium as well as in the apex of the heart.

In striated muscle cells of different tissues, such as tongue and skeletal muscle, a more diffuse staining pattern was obtained (Fig. 2A), and the fibrillar pattern, as seen in the myocard was not as evident. Neither in the heart nor in other striated muscle cells, crossstriation of cardiotin was found. No cardiotin was found in smooth muscle cells surrounding blood vessels (compare Fig. $1 \mathrm{~A}$ and $1 \mathrm{E}$ with $1 \mathrm{~B}$ and $\mathrm{F}$ ) or in smooth muscle layers of the small intestine, colon, stomach, and esophagus (compare Fig. $2 \mathrm{C}$ with $2 \mathrm{D}$ ). Also in other tissues of non-muscle origin, such as epithelia (see: Materials and Methads) and stroma, no cardiotin was detected using the monoclonal cardiotin antibody. In double-label immunofluorescence assays of adult human myocard sections codistribution of cardiotin and titin in the same cells was evident (Fig. $3 \mathrm{~A}_{,}, \mathrm{B}$ ), while these cardiomyocytes also contained desmin but no vimentin.

\section{Species cross-reactivity of the anti-cardiotin antibody}

The monoclonal anti-cardiotin antibody was tested on frozen sections of heart, tongue, esophagus (in some species containing striated musclie cells), skeletal muscle, and smooth muscle llayers of the small intestine dissected from different animal species. The sections were pretreated routinely with $0.5 \%$ Triton $X-100$ in PBS. In comparison with cardiotin lacalization in the human myocard, a similar fibrillar reaction pattern between the myofibrils was seen in heart tissue of Rhesus monkey (Fig. 4A), cow, goat (Fig. 4C), dog, cat, rabbit (Fig. 4E, F), mouse (Fig. 4D), chicken, and Xenopus laevis. In rat heart tissue no cardiotin could be detected.

In cytospin preparations of isolated adult rabbit heart myocytes a strong cardiotin reaction patterin was found between the myofibrils with anti-cardiotin antibody (Fig. 4G). Similar to the situation in man, cardiotin filaments are perpendicularly localized to the characteristic cross striated pattern of desmin (Fig. $4 \mathrm{H}$ ).

In striated muscle cells from tongue, esophagus and skeletal muscle of the tested animals, with exception of the rat, a relatively weak and diffuse cardiotin staining pattern was detected. In rat striated muscle cells no cardiotin could be detected. In all animal tissues examined smooth muscle cells, stroma and epithellia were negative for cardiotin.

\section{Age-related expression of cardiotin}

From our immunohistochemical assays with different species and different tissues from mammals of different age, it became apparent that expression of cardiotin in the myocard is age-dependent.

In a 16-week-old human embryonic heart tissue no cardiotin was found (Fig. 5A), although vimentin was found to stain connective tissue and no cardiomyofibrils (Fig. 5B). while titin and desmin both showed a striated staining pattern (Fig. 5C, D). As mentioned above adult human heart tissue is strongly positive for cardiotin. 

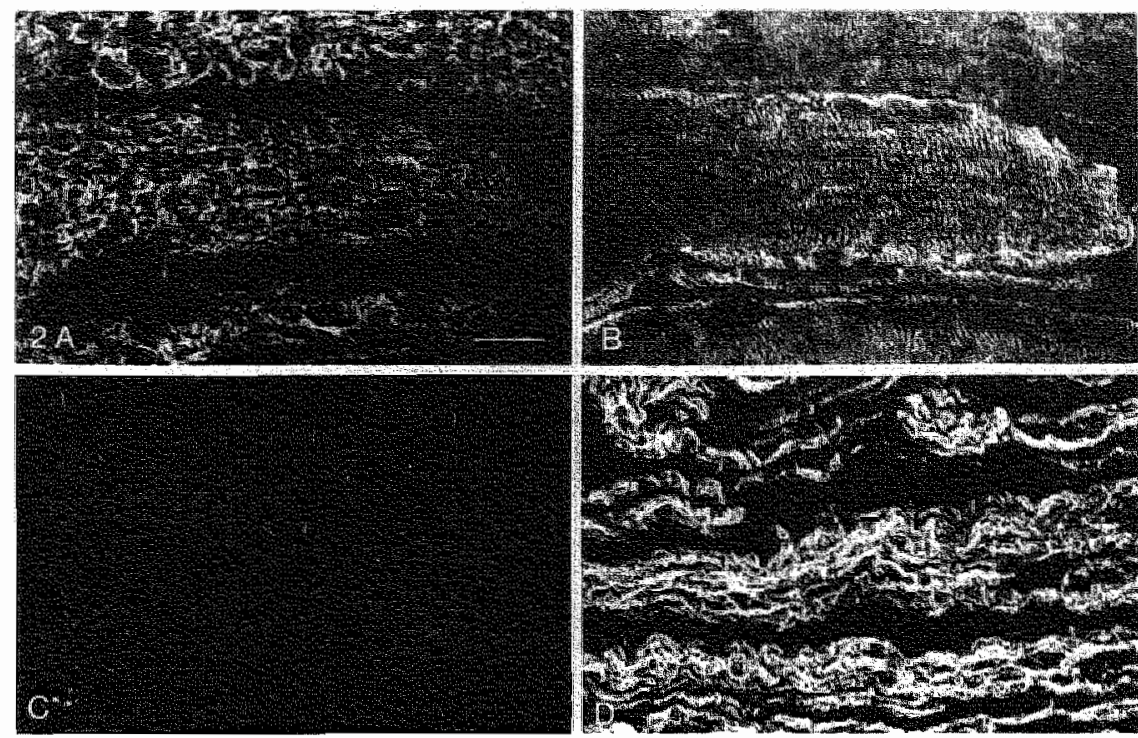

Figure 2: Double-label immunofluorescence micrascopy of adult human skeletal muscle $(A, B)$ and adult smoath muscle of human esophagus $(\mathrm{C}, \mathrm{D})$, incubated with the monoclonal antibody to cardiotin $\{A, C)$, a monoclonal desmin antibody (DE-R-11; B) and a polyclonal antibody to desmin (pDes; D). Bar indicates $25 \mu \mathrm{m}$ for $\mathrm{A}, \mathrm{B} ; 50 \mu \mathrm{mr}$ for $\mathrm{C}, \mathrm{D}$.
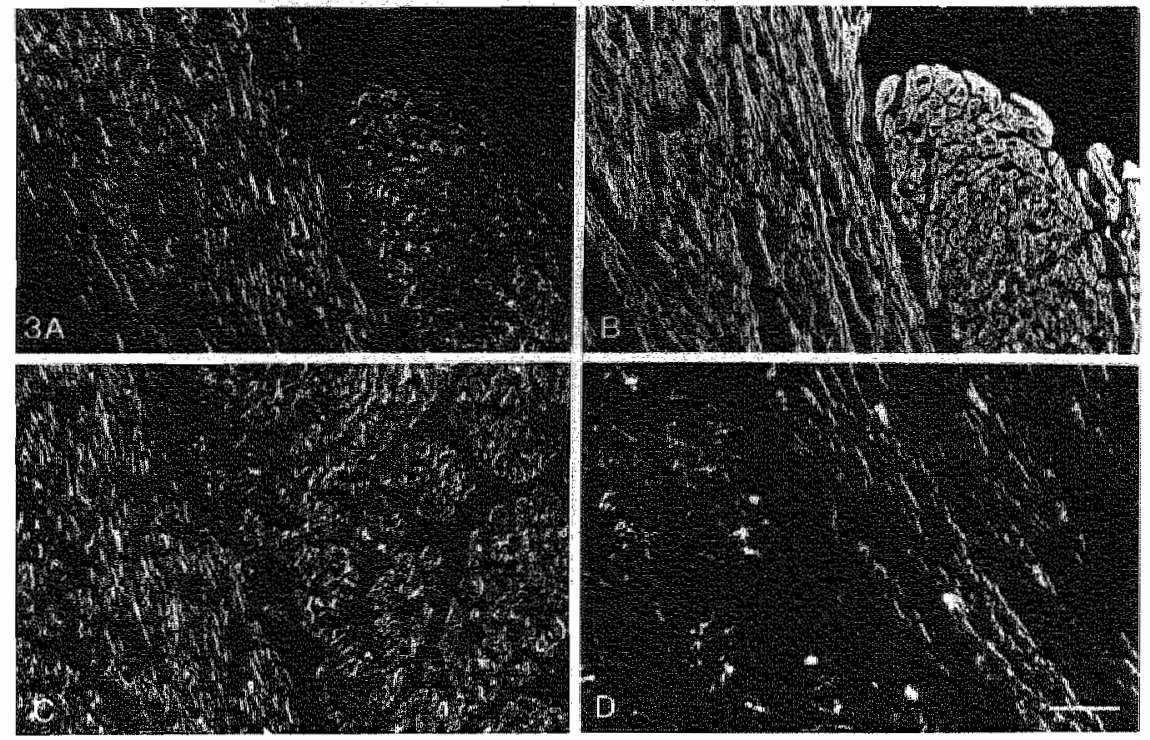

Figume 3: Adult human myocard sections after extraction with $0.5 \%$ Triton X-100 (A, B), $0.5 \%$ Triton X-1100 and $\mathrm{NaDOC} / \mathrm{Tw}$ wen 40 (C) or $0.5 \%$ Triton $X-100$ and $\mathrm{KU} / \mathrm{KCl}(\mathrm{D})$, incubated with the monoclonal antibody to cardiotin $(F, 2 G: A, C, D)$ and a polyclonal titin antiserum lp Titin; $B$, doublewstaining of $A$. Bar indicates $80 \mathrm{\mu m}$ for $\mathrm{A}-\mathrm{C} ; 40 \mathrm{\mu m}$ for $\mathrm{D}$. 

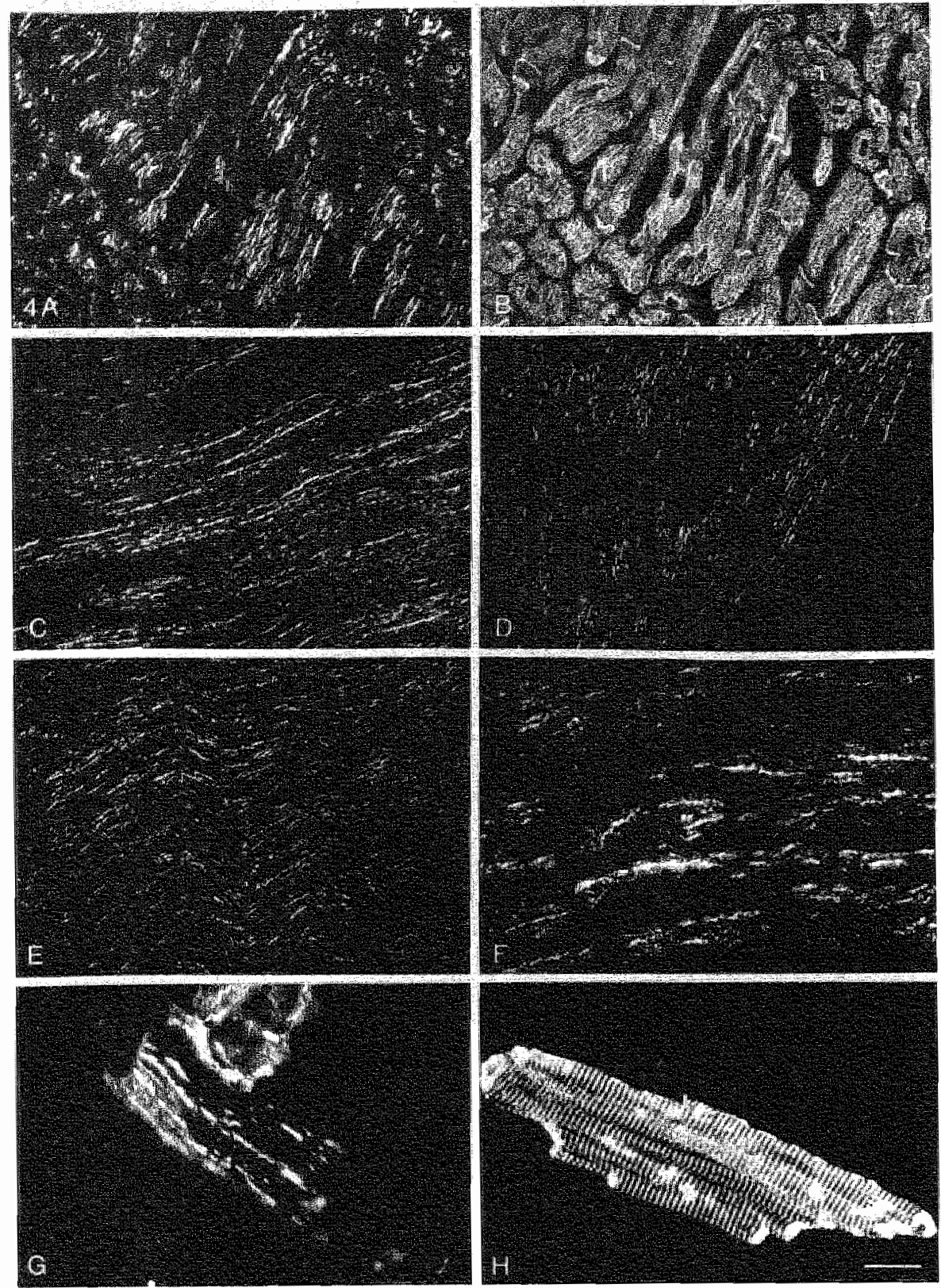

Figure 4: Immunofluorescence micrograns of heart sections of Rhesus monkey (A, B), goat (C), mouse 10., and rabbit $(E, F)$ stained with the monoclonal antibody to cardiotin $(A, C-F)$. In Fig. 4 A, B a doublelabel inminofiworescence staining of adut Rhesus monkey heart 20 years oidl, staned with the monoclonal cardiatin artibody (R2G; Al and a monaclonal antibody to desmin (DE-R-11; B) respectively. in Fig. 4G, H isolated cardiomyocytes of rabbit stained with R2G $(G)$ and $p D e s(H)$. Bar indicates 12.5 um for G, H: $20 \mu m$ for F; 40 kn for $A, B ; 80 \mu m$ for $C_{n} D, E$. 

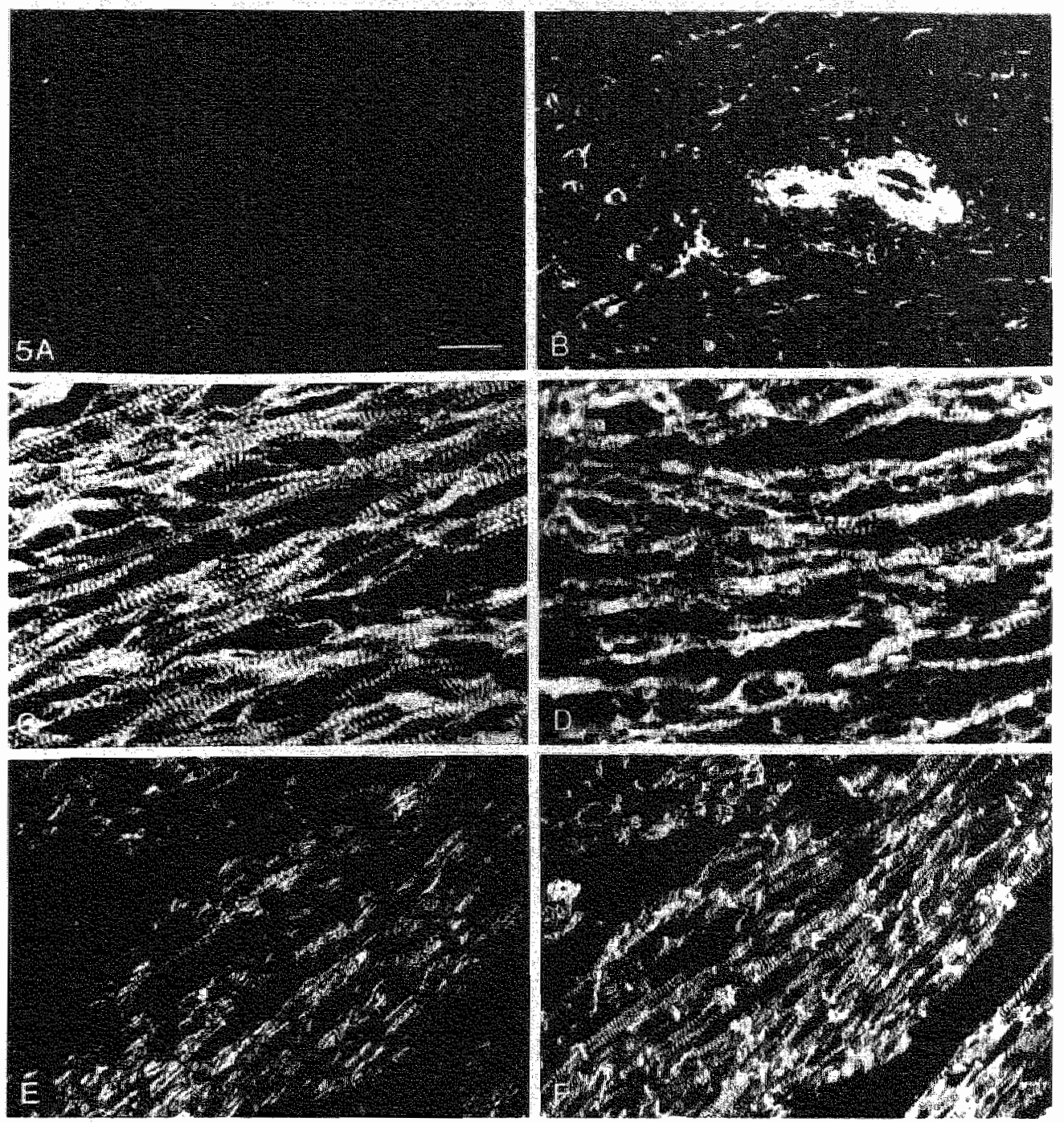

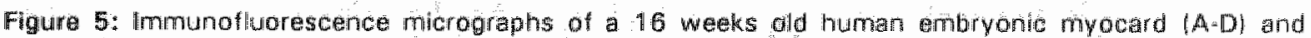

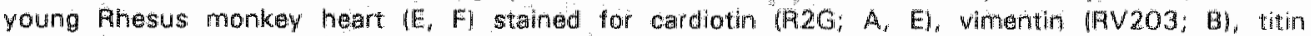
(9D10;Cl, and desmin (pDes: D and OEF-11; Fl. Note the absence of cardioth in the thuman embryonic myocard in contrast to the young Rhesus monkey myocard in whict the presenow of cardiotin can bo

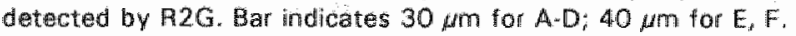

In rabbit embryos of different stages of development $18,10,13,18,23$, and 28 days post coitum (d.p.c.) no cardiotin was detected, neither in the developing heart region, nor in the myotomes. We have described before $[55]$ that during cardiomyogenesis of the rabbit heart titin is expressed as early as the 0 to 1 somite pair embryos " and is one of the earliest markers to detect the heart-anlagen. Cardiomyofibrits with a clearcrossstriated pattern of titin or desmin were observed in rabbit embryos of 5 to 8 somites $(8.0-9.0$ d.p.c.) and $>30$ somites $(13 \mathrm{~d} . \mathrm{p.c}$.), respectively.

In frozen theart sections of 5 months and 13 months old Rhesus monkeys, incubated in 

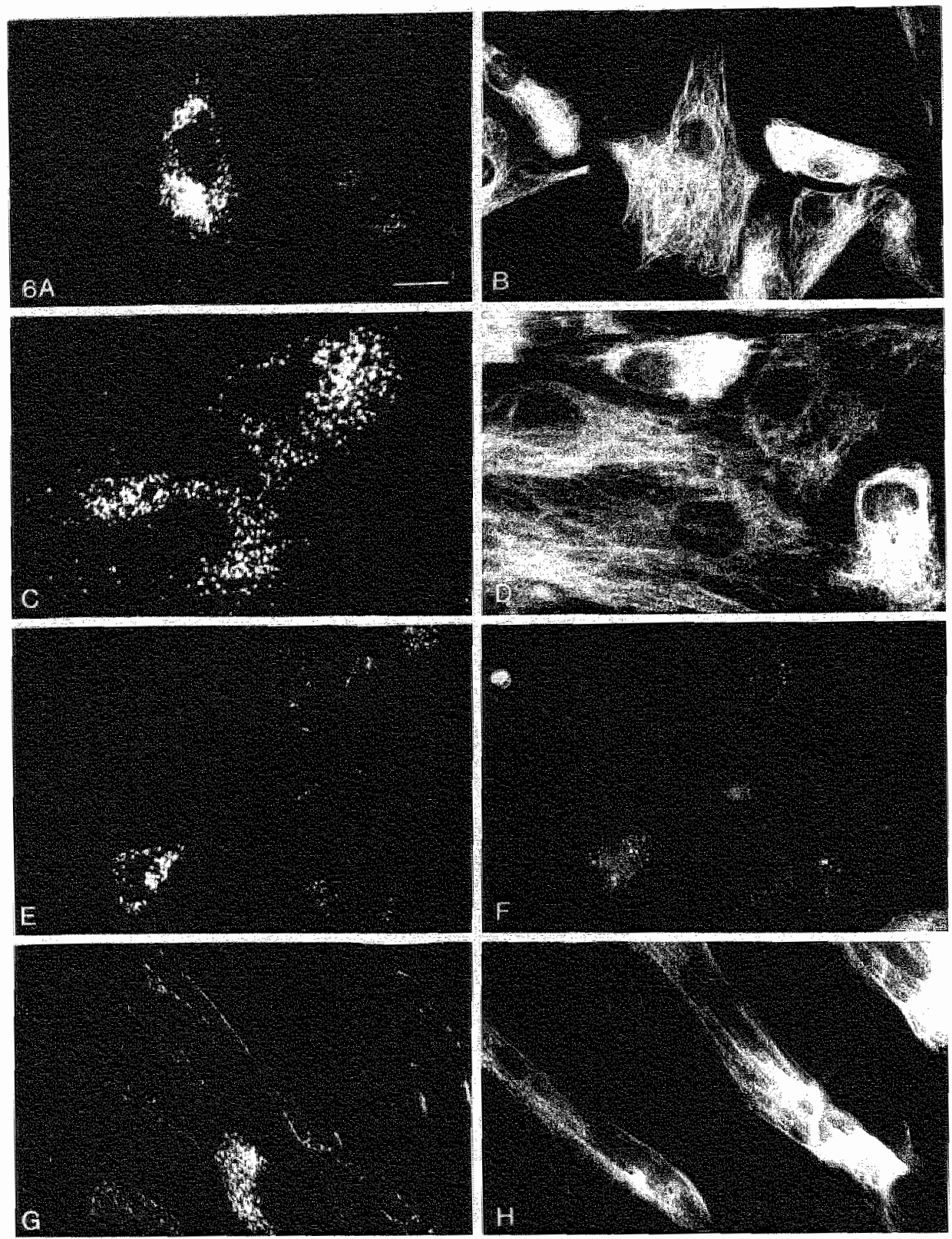

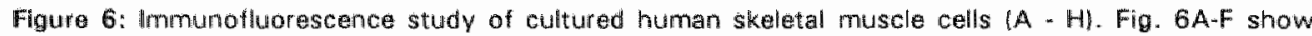
undifferentiatad human skeletal muscle cells in witro stained with anti-cardiotin $\langle A, C$, E and doublestained with polyclonal antisera directed to desmin (pDes; B. Dl and titin ip Titin; Fl. Double-label immunofluorescence $\{G, H$, of differentiated humain skeletal muscle cols in witro stained with the monochonal antibody to cardiatin $(G)$ and the polyclonal thtin antiserum $(H)$. Bar indicates $25 \mu m$ for $A_{\text {. }}$ 19. E-H: $12.5 \mu \mathrm{m}$ for $\mathrm{C}, \mathrm{D}$. 
double immunofiuorescence assays, a relatively veak, occasionally diffuse staining pattern was detected for cardiotin (Fig. 5 E). In these tissue sections not all the cardiomyofibrils were cardiotin positive. With the desmin monoclonal antibody (DE-R-11) a clearly cross-striated staining pattern was detected in both specimens (Fig. $5 \mathrm{~F}$ ), throughout the complete myocard. Also the intercalated discs were stained for desmin in these heart sections of the young monkeys. In the adult, 20 years old, monkey heart IFig. $4 A$, Bi a normal staining pattern, comparable to that seen in the adult human heart, was detected for cardiotin and desmin.

\section{Cardiotin in cultured human skeletal muscle cells}

In $25 \%$ of cultured, postmitotic mononuclear human skeletal muscle myoblasts, a typical perinuclear punctate staining pattern was found for cardiotin in the cytoplasm IFig. 6A. C). while in all of these polygonal muscle cells a flamentous staining pattern was found for desmin (Fig. 6B, Dl. In the double-label immunofluorescence assays of these undifferentiated human skeletal muscle cells no co-localization was found when the punctate cardiotin pattern was compared to the characteristic pattern of spots obtained with a polyclonal titin antiserum (Fig. 6E, F). Note that not all the cardiotin positive cells are positive for titin.

In the in vitro differentiated multinuclear myotubes no intracellular staining was found for cardiotin (Fig. 6G), while a filamentous to stress fiber-like staining pattern was detected for titin (Fig. 6H).

\section{Subcellular localization of cardiotin in the myocard}

Immunofluorescence assays of adult human cardiomyocytes show cardiotin filaments to be located intracellularly between the cardiomyofibrils, perpendicular to the sarcomere striated pattern as detected by desmin (Fig. 1C, DI and titin (Fig. 3A, B). The individual filament structures running parallel to each other span many myofibrillar sarcomeres. As determined by means of CSLM the length of the cardiotin filament structures ranged from 12 to $80 \mu \mathrm{m}$. The distance between cardiotin filaments seems to be constant in most cases, showing an average distance of $2.3 \mu \mathrm{m}$ as determined after 100 measurements

(Fig. 7). Combining the cardiotin antibo-

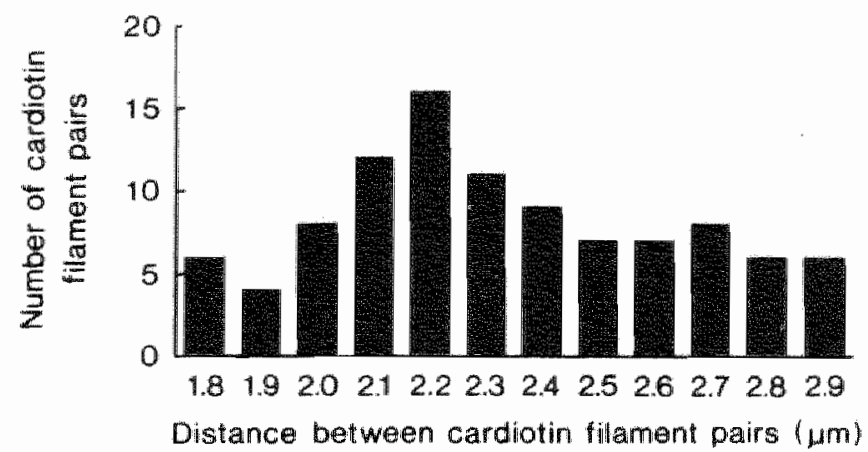

Fingure 7: Histogram showing the distribution of the distance between cardiotin filaments as measured by CSLLM. Onenundred estimates of the distance between parallel funning cardiotim filaments were performed. dy with an antiserum to the basal membra. ne constituent colla gen type IV, showed that cardiotin fila ments were always located inside the muscle cells (results not snown). In dou ble-labal immuno. fluorescence assays cardiotin could not be detected in the intercalated discs (Fig. $1 \mathrm{O} \mathrm{H}$ which are strongly positive with antisera 10 desmin (Fig. ID) and 


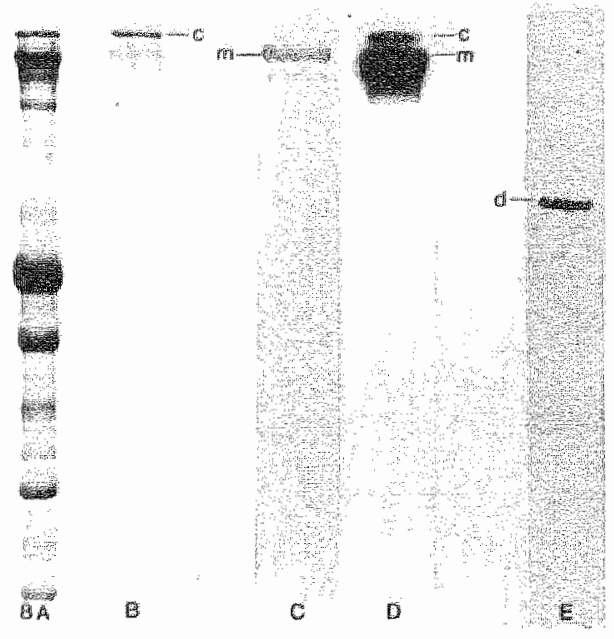

Figure 8: Immunoblottings of cardiotn in extracted human heart tissue sections. Iane Al Page Blue stained gel of nomal human heart extracted with $1 \%$ Trton $x-100$ in Pes contannng $0.001 \%$ trypsin. lanes $B$ and $\mathrm{Cl}$ Immunoblots of normal human heart incubated with the monoclonal antibody to cardiatin (lane B) and myosin (tane C). lane D) Lane B subsequently incubated with a myosin artibody IMF2OH. lane El Desmin as detacted with ROJO1. E: cardiotin (t) 300 kDal: m: myosin $(200 \mathrm{kDa})$ : desmim (53) kDal. desmoplakins (Fig. $1 \mathrm{HI}$. In fact it seemed that the cardiotin fibrils did not cross this boundary. In transwerse sections of the myocard, cardiotin was also found to be located between the emyofibrils (Fig. $3 \mathrm{C}, \mathrm{D})$.

\section{Cardiotin is a highly insoluble structural component of the myocard}

\begin{abstract}
Extraction of human heart cryostat sections with $1 \%$ Tritor $x-100$ apparently had no significant effect on the cardiotin structure as concluded from the immunofluorescence staining pattern (Fig. 3A). A KCl/KI extraction step or treatment of the sections with

NaDOCITween 40 solutions had also no dramatic effects on the staining results of the cardiotin antibody (Figs 3C. D). A very weak reaction was found after methanolacerone fixation of the tissue. indicating that the anti-cardiotin epitope is sensitive to fixation in organic solvents.
\end{abstract}

\section{Cardiotin is a high molecular mass protein}

For the determination of the molecular mass of the cardiotin protein subunit. Triton $\times-100$ extracted $20 \mu m$ thick cryostat sections of fresh frozen human heart were analyzed after SDS.PAGE and immunoblotting. A weak immunoreaction with a high molecular mass $1>300$ Kal protein band. migrating just below at the interface between the stacking and the running gel was found with anti-cardiotin in blots of $12 \%$ acrylamide gels. After extraction of $20 \mu \mathrm{m}$ myocard sections with $\mathrm{KI} / \mathrm{KCl}$ or NaDOC Tween 40 in the presence of $1 \%$ Triton $\mathrm{X}-100$ a similar result was obtained tresult not shown. A slightly stronger staining of this high molecular mass protein could be detected when human heart Samples ware treated with $0.001 \%$ trypsin (Fig. 8. lane B) or $0.025 \%$ DNAse (result not shown) in the presence of $1 \%$ Triton $X-100$. To determine the molecular mass of cardio. tin more precisely. the same blot was reincubated with a monoclonal antibody to sarcomeric muscle myosin (MF20) detected at the $200 \mathrm{kDa}$ molecular mass level (Fig. 8. lane Ch. After the subsequent incubation of the blot with $R 2 G$ and anti-myosin, it is clearly seen that the $200 \mathrm{kDa}$ myosin migrates further into the gel than the cardiotin band (Fig. B, lane D). An exact molecular mass for cardiotin can not be given sofar. As a control, desmin was detected in these samples, showing a $53 \mathrm{kDa}$ protein without significant breakdown products (Fig. 8, lane E).

Immunoprecipitation studies with radio-labelled extracts from cultured human skeletal muscle cells also revealed a protein band, migrating above the $200 \mathrm{kDa}$ marker protein in a $110 \%$ polyacryl-amide gel $1 \mathrm{Fig} .91$. 


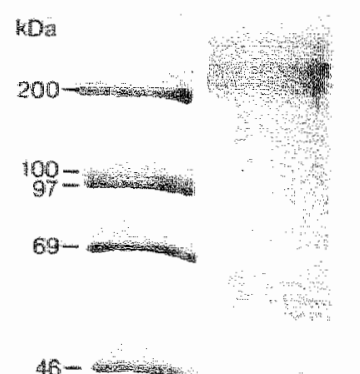

ST-

30

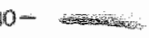

9.4

B

$\mathrm{c}$

Figure 9: Autoradiographs of $10 \%$ SDS polyacryl amide gels containing: lane A) Fadiolabelled molecular mass markers; lane B! Trinon $X-100$ extract of cultured human skeletial muscle cells, immuno-pirectipi. tated with the monoclonal antibody to cardiotim; arrowlinead indicates the specifically precipitated cardiotin protem band at a molecular mass level of approximatrely $300 \mathrm{kDa}$; lane C) Human skeletal musche cell extract as in lane $\mathrm{B}$. immuno preciphtated with an unrelated morocional antibody of the IgMclass, used as a control. we have examined, the cardiotin tissue distribution, showed a similar pattern as described for human tissues. The fact that this holds true for animals as distant as amphibia and birds indicates the importance of cardiotin in the proper functioning of striated muscle cells, in particular of the heart. The fact that rat myacard is negative, is probably due to a difference in the structure of the cardiotin-epitope recognized by $\mathrm{R} 2 \mathrm{G}$, or to masking of this region in the protein

In vitro differentiating human skeletal muscle cells revealed the presence of cardiotim in polygonal undifferentiated myoblasts. During myofibrillogenesis in vitro of the human skeletal muscle cells the cardiotio spots disappear very early in the differentiating process, in contrast to titin spots [56].

During embryonic development of the heart in man and rabbit, no significant expression lewels of cardiotin could be defected, in contrast to other muscle-specific proteins such as titin, myosin and desmin. These are expressed very early in the developing heart of man and rabbit 155,641 . Rhesus monkey myocard tissue obtained five months after birth did already show a fibrillar cardiotin pattern which was less abundant than the pattern seen in adult Rhesus monkey myocard. This age related expression pattern of cardiotin parallels the deposition of the sarcoplasmic reticulum (SR) around the myofibrils 17, 81. The findings suggest a possible relation between cardiotin and these SP structures, a correlation that is also supported by the subcellular localization of the fibrillar cardiotin structures (see below).

In conclusion, cardiotin seems not to be of significant importance for the early development of the heart, but it plays a role in a proper functioning of the adult heart. 
In myocard tissue of different species, a similar intracellular cardiotin distribution pattern became apparent, i.e., longirudinally oriented flaments, running parallel at a regular distance spanning several sarcomeres, and always within the basement membrane surrounding the cell. The avarage width of normal adult human cardiomyonibrils is approximately $2 \mathrm{pm}$. The average distance betwen the cardiotin filaments was estimated to be $2.3 \mathrm{fm}$. This strongly suggests that cardiotin in human heart is situated between these myofibrils. This was also evident from the transverse sections, where cardiotin was also seen to be located between individual fibrils. Double-label immunofluorescence studies on frozen sections of myocard with a basal membrane antibody supported this idea, and also showed that cardiotin is located intracellular. No obvious connection of cardiotin molecules with the intercalated disc seems to exist. This localization of cardiotin bears some resemblance to the distribution pattern to be expected for the SR [7, 8]. Immunoelectron microscopy studies under progress will have to reveal its exact distribution and possible association with other structures.

In striated muscle cells of the tongue, esophagus and skeletal muscle tissue, no precise localization of the cardiotin structure could be determined on basis of light microscopy. The difference in the localization of cardiotin in cardiomyocytes as compared to skeletal muscle may be of functional importance.

The typical cardiotin spots in cultured human skeletal muscle cells did not show colocalization with the titin spots, which indicates that these cells are still polygonal but have already initiated differentiation $145,52,561$. In fact, the distribution pattern of cardiotin observed in these cultured postmitotic skeletal muscle cells resembles that of the endoplasmic reticulum. Therefore it will be interesting to see whether or not the diffuse staining pattern in skeletal muscle cells in vivo reflects an association of cardiotin with the SR. When compared to the staining of the SR and transverse tubules in skeletal muscle cells as described by Flucher et al. $[7,8]$, the cardiotin pattern in skeletal muscle seemed, however, different in our studies.

\section{Structure of Gardiotin}

Like titin and nebulin $133-35,50,54,601$ cardiotin is a high molecular mass protein restricted to striated muscle. Cardiotin subunits have a molecular mass over $300 \mathrm{kDa}$, but migrate below titin in polyacrylamide SDS-gells. The length of individual titin molecules, with an approximate molecular mass of $3.000 \mathrm{kDa}$, has been described to vary between $1 \mu \mathrm{m}$ and $2 \mu \mathrm{m}$ 154\%. The cardiotin filaments showed a length wariation of $12 \mu \mathrm{m}$ to 80 $\mu / m$ as estimated by CSLM in frozen sections. This can only mean that these structures consist of cardiotin polymers. Unlike titin antibodies, the cardiotin antibody R.2G shows a rather uniform staining of the filaments, no real periodicity was observed. This may mean that the epitope recognized by $R 2 G$ occurs as a repeated motit within the subunit moleculle. Repeated motifs have been shown to occur in ather high molecular mass proteins such as titin $[27,54]$ and nebulin $[26,54,66]$. Alternatively a staggered assembly of overlapping cardiotin molecules may be responsible for the formation of the long cardiotin fllaments, in analogy to the structure of intermediate filaments.

Future studies at the molecular level will have to reveal the basic structure of the cardiotin molecule. which will then allow to draw up a more precise model for cardiotin assembly. 
Acknowledgements: We thank Kiek Verijp and Hannis hobben IDepartment of pathology.

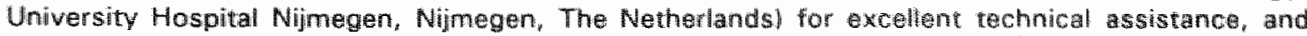
Esther van der Ven (Department of Medical Microblology, University Hospital Nimegen, Nimegem, The Netherlands/ for providing Rhesus monkey heant tissues.

\section{REFERENCES}

1. Bandman E: Contractile protein isoforms in muscie development. Dev. Bol. 154, 273-283, 1992.

2. Bader D, Masaki T, Fischman DA: Immunochemical analysis of myosin heawy chain durno avian myogenesis in wivo and in vitro. J. Cell Biol. 95, 763-770, 1982.

3. Debus $\mathrm{E}$. Weber $\mathrm{K}$, Osborn $\mathrm{M}$ : Monoclonal antibodies to desmin, the muscle specific intermediata filament. EMBO $\mathbb{J}, 2,2305-2312,1983$.

4. Epstein HF, Fischman DA: Molecular analysis of protein assembly in muscle dewelopment. Scilence $251,1039-1044,1991$.

5. Epstein HF. Bernstiein SI: Genetic appiraaches to understanding muscle development. Dev. Biol. $154,231-244,1992$.

6. Fischmain DA: Myotibrillogenesis and the morphologenesis of skeletal muscle. In: Myology. Basic and Chinical. leds. Engel AG, Banker BOl McGraw-Hill, New York, pp 5-30, 1986.

7. Flucher BE. Philips JL, Powell JA, Andrews SB, Daniels MP; Coordinated development of myofibrils, sarcoplasmic reticulum and transverse tubules in normal and dygenic mouse skeletal

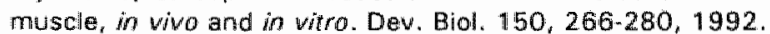

8. Fiucher BE: Structural analysis of muscle development: transverse tubules, saricoplasimio reticulum, and the triad. Dev. Biol. 154, 245-260, 1992.

9. Foelmer $H G$, Madri JA Furthmayr $H$. Monoclomall antibodies to type IV collagen: probes for the study of structure and function of basement membranes. Lab. Invest. 48, 639-649, 1983 .

10. Franke WW, Schmid $\mathbb{E}$, Osborn $M$, Weber $K$ : Diflerent intemediate-sized filamemts distinguished by immunofliuorescence microscopy. Proc. Natl. Acad. Sci. USA 75, 5034-5038, 1978.

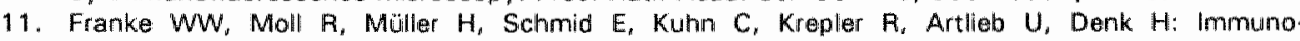
cytochemical identification of epithelium-derived human tumors with antibodies to desmosomal plaque proteins. Proc. Natl. Acad. Sci. USA 80,543-547, 1983.

12. Fulton AB, Isaacs WB: Titin, a huge, elastic sarcomeric protein with a probable role in morphogenesis. BioEssays 13, $157 \times 161,1991$.

13. Finist DO, Osborn $M$, Nave $R$, Weber K: The organization of titin filaments in the half sarcomerre revealed by monoclonal antibodies in ammunoelection microscopy. J. Cell Btiol. 106, $1563-1572$, 1988.

14. Gard DL, Lazarides $E$ : The synthesis and distribution of desmin and vimentin during myogenesis in vitro. Cell $19,263-275,1980$.

15. Gassner D: Myofibrilar interaction of blot immunoaffinity-purified antibodies against rative titin as studied by indirect immunofluorescence and immunogoid staining. Eur. J. Cell Biol. 40, 176 m. 184. 1986.

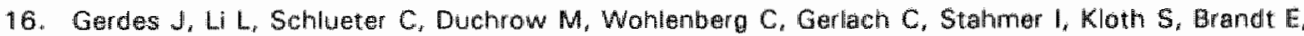
Flad H.-D. Immunobiochemical and molecular biblogic characterization of the cell prolifierationassociated nuclear antigen that is defined by monoclonal antibody Ki-67. Arm. J. Path. 138, 867. 873,1991

17. Granger BL, Lazarides E: Desmin and wimentin coexist at the pariphery of the myofbril $\mathbb{Z}$-disc. Cell $18,1053-1063,1979$.

18. Greaser ML, Handel SE, Wang SM, Schultz E, Bulinski JC, Lessard JL: Assermbly of titin, myosin. actim, and tropomyosin into myofibils in cultured chick cardiomyocytes. In: Collular and Molecular Brology of Muscle Dewelopment. UCLA Symposium on Molecular and Cellutlar Blology, New Series, Vol. 93 leds. Stockdale F, Kedes LI Alan R. Liss, New York, pp. 246-257, 1989.

19. Handel SE, Greaser ML, Schultz E, Wang SM, Duliniski JC, Lin JJC, Lessard JL: Chicken auru cardiac myofibrillogenesis studied with antibodies specific for titin and the muscle and nonmuscle isotorms of actin and tropomyosin. Cell. Tissue Res. $263,419-430,1991$.

20. Hill $C$. Weber $K$ : Monocional antibadies distinguish titin from heart and slkeletal muscle. J. Cell Biol. $102,1099-1108,1986$.

21. Hill CS, Duran S, Zhongxiang L. Weber K, Holtzer H: Titin and myosin, but not desmin are linked during myofibrillogenesis in postmitotic mononucleated myoblasts. J. Cell Biol. 103, 2185-2196. 1986.

22. Horowits $\mathbb{R}$, Podolsky RJ: The positionall stability of thick filaments in activated skeletal muscelle 
depends on sarcomere lengths: widence for the role of titin thaments. S. Cell Biol. 105, 22172223,1987 .

23. Jin J.F. Wang $k$ : Cloning, expression, and protein interaction of human nebulin fiagments composed of varying numbers of sequene modules. J. Biol Chem. 226, 21215-21223, 1991.

24. Konher $Q$, Milstein $C$ : Continous: cultures of fused cells secreting antibody of predefined specitity. Nature $256,495-497,1975$.

25. Kruger M, Wright $J$, Wang K: Mebulin as length regulator of thin filaments of vertebrate skeletal muscles: correlation of thin filament length, nebulin size, and epitope profile. J. Cell Blol. 115,97$107,1991$.

26. Labeit $S$, Gibson $T$, Lakey $A$, Leonard $K$, Zevani $M$, Knight P, Wardale J, Trunick J: Evidence that nebulin is a protein ruler in muscle thin filaments: FEBS Lett, 282, 313-316, 1991 .

27. Labeit $S$, Gautel M, Lakey A, Trinick J: Towards a molecular understanding of titim. EMBO J. 11 . $1711.1716,1992$.

28. Laemmfl UK: Cleavage of structural proteins during the assembly of the head of bacteriophage Th. Nature $227,680-685,1970$.

29. Lazarides E. Hubbard $\mathrm{BD}$. Immunochemical characterization of the subunit of the $100 \mathrm{~A}$ thlaments from muscle. Proc. Nati. Acad. Sci. USA 73, 4344-4348, 1976.

30. Laxarides E: intermediate fifaments as mechenical integrators of cellular space. Nature $282,249$. $256,1980$.

31. Lessard Jh: Two monoclonal antibodies to actin: one muscle seletive and one general reactive. $J$. Cell Motil. Cytoskel, 10, 349-362, 1988.

32. Lin JJC, Chou CS, Lin JLC: Monochonal antibodies against chicken tropomyosim isotorms: production, characterization and application. Hybridama $4,223-242,1985$.

33. Maruyama $K$, Natori $R$, Nanomura $Y$ : New elastic protein from muscle. Nature 262, 58-60, 1976.

34. Maruyama $K$, Sawada $H$, Kimura $S$, Ohashi $K$, Higuchi $H$, Umazume $Y$ : Connectin filaments in stretched skinned fibers of trog skeletal muscle. J. Ceil Biol. 99, 1391-1397, 1984.

35. Maruyama K: Connectin, an elastic fllamentous protein of striated muscle. Int. Rev. Cyt. $\| 04,81$. 114.1986 .

36. Maruyama K, Matsuno A, Hiquchi H, Shmaoka S, Kimura S, Shimizu T: Behaviour of connectin (titin) and nebulim in skinned muscle fibers released after extreme stretch as revealed by immunoelectron microscapy. J. Muscle Res. Cell Motil. 10, 350-359, 1989.

37. Osborn $M$, Weber $K$. Immunofluorescence and immunocytochemical procedure with aftinity purified antibodies: tubulim-containing stuctures. Methods Cell Biol. 24, 97-132, 1982.

38. Pieper FR, Slobbe RL., Ramaekers FCS, Cuypers HT, Bloemendal H: Upstream regions of the hamster desmin and vimentin genes regulate expression during in vitro myogenesis. EMBO J. 6. $3611-3618,1987$.

39. Quinlan RA, Franke WW: Heteropolymer fllaments of vimentin and desmin in vascullar smooth muscle tissue and cultured baby hamster kidney cells demonstrated by chemical crosslinking. Proc. Natl. Acad. Sci. $79,3452-3456,1982$.

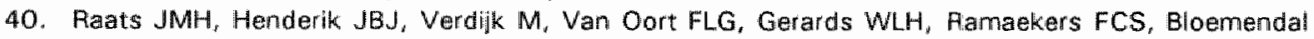
H: Assembly of carboxy-terminaly deleted desmin in vimentin-free cells. Eur. J. Cell Biol. 56, 84103,1991

4. Ramaekers FCS. Puts JJG, Kant A, Moesker O, Jap PHK, Voolls GP: Use of antibodies to intermediate fillaments in the chatacterization of human tumors. Cold Spring Harb. Symp. quant. Blal. $46,331-339,1981$.

42. Ramakers FCS, Puts JJG. Moesker $O$, Kant A, Huijsmans $A_{\text {, Hag }} \mathrm{D}$, Jap PHK, Herman CJ. Voojis GP: Antibodies to intermediate fllament proteins in the immunohistochemical identification of thuman tumour \&: an overwiew. Histochemical $\rfloor .15,691-713,1983$.

43. Aamaokers FCS, Moesker O, Huijsmans A, Schairt G, Westerthof G, Wagenaar SiSc, Herman CJ, Voolls GP: Intermadiate filament proteins in the study of tumor heterogeneity: an in-depth study on tumors of the Lrinary and respiratory tracts: Ann. NY. Acad. Sci. 455, 614-634, 1985.

44. Schaert $G$, Webahn $C$, Langmann $W$. Ramaekers $F$ : Desmin and titin expression in early postimplantation mouse embryos. Development 107, 585-596, 1989 .

45. Schaart G, Pieper FA, Kuijpers HJH, Bloemendal H, Ramaekers FCS: Baby hamster kidney 1 BHK21(C13) cellis can express striated muscle type protens. Differentiation $46,105-115,1991$.

46. Schart $G$, Van der Ven $P$. Ramaekers $F$ : Cardiotin, a recently characterized component in the cardiovascular system. Histochem. I24,574 \{abstract). 1992 .

47. Schast G. Van der Vem P. Ramaekers F: Cardiotin and vasculin, two recently characterized components in the cardiovascular system. J. Muscle Res. Cell Motil. 14,236 labstract 1993.

48. Schultheiss $T$, Lin Z, Ishikawa $H$, Zamir $I$, Stoeckert CJ, Holtzer H: Desminhimentin intermediate flaments are dispensable for many aspects of myogenesis. J. Cell Biot. 114, 953-966, 1991. 
49. Smatl JV. Sobieszek A: Studies on the function and composition of the 10 mm (100 A filmments of vertebrate smooth muscle. 1. Cell 5ci. 23, 243-268, 1977.

50. Stedman $H$, Browning $K$. Oliver $N$, Oronzi-Scott $M$. Fischbeck $K$, Sarkar $S_{a}$ Sylvestur d, Schmicket A. Wang K: Nebulin cDNA detect a 25 kilobase transcrpe un skeletal muscle and Hocalz to humbn chromosome two. Genomics 2, 1/-7, 1988.

51. Tokuyasu KT, Maher PA, Singer SJ: Distributions of wimentin and desmin in developing chick myatubes in wivo. I. Immunofluorescence study. J. Cell Biol. 96, 1961) 972 (1984).

52. Tokuyasu KT. Maher PA: Immunocytocthemical studies of cardiac myotibrillogenosis in earty chick embryos. I. Presence of immunofuorescent spots in premyolibril stages. J. Cell Biol. 105, 2781$2793,1987$.

53. Towbin H, Staehelin T, Gordon J: Electrophoretic transfer of proteins from polvacrylamide oels to nitrocellulose sheets: procedure and some aplications. Proc. Nati. Acad. Sci. USA 76, 4350. $4354,1979$.

54. Trinick J: Understanding the functions of titin and nebulin. FEBS Lett. 307, 44,48, 1992.

55. Van der Loop FTL, Schaart G, Langmann W, Famaekers FCS, Viebahn C: Expression and organization of muscle specific proteins during the early developmental stages of the rabuit heart. Anat. Embryol. 185, 439-450, 1992.

56. Wan der Ven PFM, Schaart G, Jap PHK, Sengers RCA, Stadhouders AM, Ramaekers FCS: Differentiation of human skeletal muscle cells in culture: maturation as indicated by titin and desmin striation. Cell Tissue Res. 270, $189-198,1992$.

57. VerDonck $L$. Verellen $G$, Geerts H, Borgers M. Lysophosphatidylcholine-induced C ${ }^{2+}$-overloaded in isolated cardiomyacytes and effect of cytoprotective drugs. J. Mol. Cell Cardiol. 24, $977-988$. 1992.

58. Viebahn C. Lane EB. Ramaekers FCS: Keratin and vimentim expression in earty organogenesis of the rabbit embryo. Cell Tissue Res. $253,553-562,1988$.

59. Wang K. McClure J. Tu A: Major myofibrillar components of striated muscle. Proc. Natl. Acad. Scil. USA $76,3698.3702,1979$.

60. Wang $K$, Ramirez-Mitchell $R$ : Identification of an N2.lime protein of striated muscle. Proc. Natt. Acad. Sci. USA 77, 3254-3258, 1980.

61. Wang $K$, Wright $J$ : Architecture of the sarcomere matrix of skeletal muscle: immunoelectron microscopic ewidence that suggests a set of parallel inextensible nebulin filaments anchored at the Z-Hine. J. Celll Bulol, 107, 2199-2212, 1988.

62. Wang SM, Gireaser ML: Immunocytochemical studies using a monoclonal antibody to bovime cardiac titin on intact and extracted myofibils. J. Muliscle Res. Ceil Motil. 6, 293-312, 1985.

63. Wang SM, Greaser ML. Schwitz E, Bullinski JC, Lin JلJCr Lessard JL: Studies on cardiac myofibrillogenesis with antibodies to titin, actin, tropomyosin, and myosin. J. Cell Biol. 107. $1075-1083,1989$.

64. Wessels A, Vermeulen JLM, Virah Sz, Kálmán F, Lamers WH, Moorman AFM: Spatial distribution of "tissue-specific" antigens in the developing human heart and skeletal muscle. Ill. An immunohistochemical analysis of myosin heavy chain isoform expression patterns in the ombryonic hisart. Anat. Rec. 229, 355-368, 1991.

65. Whalen RG, Bugaisk LB, Butler.Browna GS, Sell SM, Schwartz K, Pinstatharstrom I: Characterization of myosin sozymes appearing during át muscle development. In: Musclo Development. Molecular and Celutar Control. Ceds. Pearson ML, Epstein NF/ Cold Spring Harbor. New York, op. 25-33, 1982.

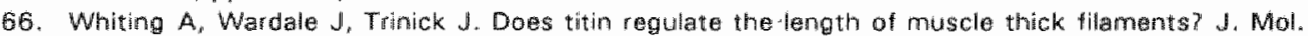
Biol. 205, 263-268, 1989 



\title{
CHAPTER 5
}

\section{TISSUE-SPECIFIC EXPRESSION OF A VIMENTIN-DESMIN} HYBRID GENE IN TRANSGENIC MICE

\author{
P.J. KRIMPENFORT, G. SCHAART, F.R. PIEPER, \\ F.C.S. RAMAEKERS, H.T. CUYPERS, \\ R.M. VAN DEN HEUVEL, W.T. VREE EGBERTS, G.J. VAN EYS, \\ A. BERNS and $H$. BLOEMENDAL
}

The EMBO Journal 7, 941-947, 1988 


\section{ABSTRACT}

We have introduced a hybrid gene, pVim2, composed of the $5^{\prime}$ region of the hamster vimentin gene encoding the head and rod domain of vimentin and the $3^{\prime}$ region of the hamster desmin gene encoding the tail domain of desmin into the germ line af mice by pronuclear injection. FNA and protein analysis of mice transgenic for this construct showed that the pVVim2 gene was expressed at high levels in a developmental and tissue-specific manner. This indicates that the vimentin-derived segment of the fusion gene contains all the regulatory elements required for vimentin-specific expression. Immunohistochemical staining of fibroblast cultures derived from the transgenic mice with artibodies specific for vimentin and desmin demonstrated that the pVVim2 protein is assembled into filaments that colacalize with the endogenous vimentin filaments. The expression of pWVim2 protein in mesenchymal cells does not interfere with the function of vimentin in these cells.

\section{INTRODUCTION}

The intermediate fillaments (IFs) have been characterized as a unique set of cytoskeletal structures, composed of cell type-specific proteins. These proteins can be divided into five distinct classes, which are expressed in a developmentally regulated and tissuespecific fashion [7, 16]. For example, desmin is only expressed in muscle cells, while wimentin is almost exclusively found in cells of mesenchymal origin [13]. In addition, vimentin is found in many cells cultured in witro $[6,31,33]$. The intermediate filament proteins are strongly related to the nuclear lamins and have been assigned to the same multigene family $[5,14]$. The IF subunits have a similar structural organization: a central conserved $a$-helical domain (rod) of -3.20 amino acid residues is flaniked by a non-helical amino-terminal head domain and a carboxy-terminal tail domain of variable length $[8,29]$. In vitro, the head and rod domains play a pivotal role in the polymerization of IF subunits $[12,30]$.

The close relationship between the IFs is also reflected in their gene structure. The exonintron organization of vimentin, desmin and the glial fibrillary acidic protein is similar and coding sequences show up to $65 \%$ homology (in case of vimentin and desmin) [18, 20 , 271. For most If genes little is known about the regulatory sequences controlling their developmental and tissue-specific expression. For hamster desmin we have shown that the region between $-89 \mathrm{bp}$ and +25 bp relative to the cap site is sufficient for cell typespecific transient expresiion. The flanking $5^{\prime}$ region of the vimentin gene contains several regulatory elements. These elements are instrumental both in the downregulation of vimentim gene expression during myogenesis [17] and in the transcriptional modulation of vimentin gene expression during myogenesis $[17,26]$.

Determination of the cell type-specific function of vimentin and the characterization of the regulatory pathways controlling virnentin gene expression is partly hampered by the fact that expression of vimentin is induced in most cells by in vitro culture. Therefore, we have introduced a vimentin-desmin hybrid gene construct into the germ line of mice to study the tissue-specific regulation of vimentin gene expression in vivo and to obtain insight in tissue-specific If functions. In this construct the last three exons of the hamster vimentin gene covering the complete tail domain were replaced by the last three exons of the hamster desmin gene. This allows recognition of the gene product in the presence of endogenous vimentin. while retaining the structural features characteristic for intermediate filaments. The expression of this fusion gene was analyzed in transgenic mice and in cell lines derived from these mice. 


\section{MATERIALS AND METHODS}

\section{Plasmid construction}

Isolation and characterization of the hamster vimentin and desmin genes have been described previously [18-21]. Intervening sequences map at similar positions in the gene. The last three exons of the vimentin gene were replaced by the corresponding exons of the desmin gene. The $9.5 \mathrm{kbp}$ BamHI-Bgll fragment harboring the first six exons of vimentin was subcloned into the BamHI site of the pUC19. A $3.4 \mathrm{kbp}$ EcoRl-Stul fragment containing the last three exons of desmin was fused to the $3^{\circ}$ end of the vimentin fragment via the EcoRl site in the polylinkel region. The complete pVWim2 hybrid gene is present on a $13 \mathrm{kbp}$ BarnHI fragment. As hybridization probe specific for hamster vimentin $M 13$ phage E49 was used, which contained a Sau3A fragment covering the region between 150 nucleotides upstream to 370 nucleotides downstream from the cap site [181. For hamster desmin the M13 phages $\times 54$ (a Sau3A insert, containing the last 25 nucleotides of exon 8 , intron 8 and the first 350 nucleotides of exon 9) and AA. 5 (a Psl-Taql insert corresponding to nucleotides 165 to 357 downstream from the stop codon [20]] were used.

\section{Cell culture}

Cell cultures from ear fibroblasts were established as described [2].

\section{Transgenic mice}

Fertilized mouse eggs were recovered in cumulus from oviducts of super *ovulated ICBA $x$ C57BI/LiA) F1 females that had mated with F1 males several hours earlier. Approximately 200 copies of the pVVim2 hybrid gene construct (without plasmid sequences) were microinjected in the most accessible pronucleus. Microinjected eggs were implanted into oviducts of 1-day pseudopregnant MA or F1 foster mothers and carried to term. Total genomic DNA was prepared from tail biopsies 3 to 4 weeks after birth. For Southern blot analysis $8 \mu \mathrm{g}$ of total genomic DNA was digested with BamHII or Stull, run on a $0.6 \%$ agarose gel and transferred to nitrocellulose. The filter was hybridized to ${ }^{32}$ P-labelled probes as described [4].

\section{Northern blot analysis}

Fifteen $\mu$ g of total cellular RNA, prepared by the LiClurrea method I1 was separated on a $1 \%$ agarose gell in formaldehyde and transferred to nitrocellulose.

\section{Immunohistochemical analysis}

The intermediate filament protein expression of tissues and cell lines was assayed by indirect immunofluorescence and Western blot analyses. The antisera used for this purpose include:

1. An affinity-purified polyclonal antibody directed against human skim keratins (pKer). This antibody reacts with virtualiy all epithelial tissues but not with non-epithelial cells [24].

2. An affinity-purified polyclonal antibody to bovine lens vimentin $(p$ Vim) $[24]$. 
3. A polyclonal rabbit antibody to chicken gizzard desmin (pDes) [25].

4. A mouse monoclonal antibody RV202 to vimentin, directed against bovine lens vimentin [3].

5. A mouse monoclonal antibody RD301 to desmin, raised against chicken gizzard desmin [3].

As second antibodies for indirect immunofluorescence assays either fluorescein isothiocyanate (FITC)-conjugated goat anti-rabbit $\operatorname{lgG}$ or FITC-conjugated rabbit antimouse $1 \mathrm{gG}$ were used at a dilution of 1:25 (Nordic. Tilburg. The Netherlands). For doublelabell immunofluorescence FITC-conjugated goat anti-rabbit IgG was combined with Texas Red (TR)-conjugated sheep (Fab') anti-mouse Ig (New England Nuclear, Boston, USA). In control experiments phosphate-buffered saline (PBS: $137 \mathrm{mM}$ sodium chloride (Merck, Darmstadt, FRG), $13 \mathrm{mM}$ disodium hydrogen phosphate dihydrate $\left(\mathrm{Na}_{2} \mathrm{HPO}_{4}, 2 \mathrm{H}_{2} \mathrm{O}, 3 \mathrm{mM}\right.$ potassium dihydrogen phosphate $\left(\mathrm{KH}_{2} \mathrm{PO}_{4}\right.$ : Merck), $\left.\mathrm{pH} 7.4\right)$ was substituted for the primary antibody. Cells on coverslips and $5 \mu \mathrm{m}$ thick frozen sections of mouse tissues were fixed in methanol (Merck) for $5 \sec \left(-20^{\circ} \mathrm{C}\right.$ ) and acetone (Merck; 3 times 5 sec), airdried and incubated with the primary antibody for 30 to $45 \mathrm{~min}$ at room temperature. Further processing for indirect immunofluorescence was performed as described [3].

\section{Gel alectrophoresis and immunoblotting assays}

Cytoskeletal preparations of eye lens were made as follows: lenses were suspended in PBS containing $1 \%$ Triton X-100 (BDH Chemicals Ltd., Poole, UK), $0.4 \mathrm{mM}$ phenylmethylsulfonyl fluoride (PMSF; Merck) and $5 \mathrm{mM}$ EDTA (Merck) for $10 \mathrm{~min}$ at $4{ }^{\circ} \mathrm{C}$. After centrifugation $(3,000 \times g$ for $10 \mathrm{~min})$ and washing (PBS) the pellet was dissolved by boiling during $5 \mathrm{~min}$ in SDS-sample buffer. For the crude desmin preparation from mouse skeletal muscle, frozen $5 \mu \mathrm{m}$ thick sections were first extracted with $1.5 \mathrm{M} \mathrm{KCl}$ (Merck), $0.5 \%$ Triton $X-100,5 \mathrm{mM}$ EDTA, $0.4 \mathrm{mM}$ PMSF in PBS, and processed as described above. One- and two-dimensional SDS-gel electrophoresis and immunoblotting was performed as described [3].

\section{RESULTS}

\section{The pVVim 2 construct}

For the construction of the vimentin-desmin hybrid gene, further referred to as pVVim2 gene, the hamster vimentin and hamster desmin genes served as starting material. Figure 1 shows a physical map of both genes. Introns in both genes map at identical positions 118, 201. In the pVVim2 contruct a $9.2 \mathrm{kbp}$ BamHI-Bglll fragment comprising the promoter region and the first six exons encoding head and rod domain of the vimentin gene were fused via the EcoRI site in the pUC19 polyliner to a 3.4 EcoRI-Stul fragment harboring the last three exons of the desmin gene encoding the tail domain. In this construct $3.1 \mathrm{kbp}$ of $5^{\circ}$ flanking DNA is present. No other constructs were examined for tissue-specific expression in transgenic mice in the study. The pVVim 2 gene construct is depicted in figure $1 \mathrm{~A}$, and the composition of the expected hybrid protein in figure $1 \mathrm{~B}$. Amino acids 1-408 comprise the head and rod domain of vimentin and amino acids 408 . 463 the tail domain of desmin. Cotransfection of the pVVim2 plasmid with the pSV2-neo plasmid into tissue culture cells (HeLa and hamster lens) results in stable transformants expressing the pVVim2 gene, as assayed with a polyclonal desmin antiserum [32]. The data show that the hybrid protein encoded by the pVVim 2 construct is able to assemble into a cytoskeletal network with normal IF appearance. 


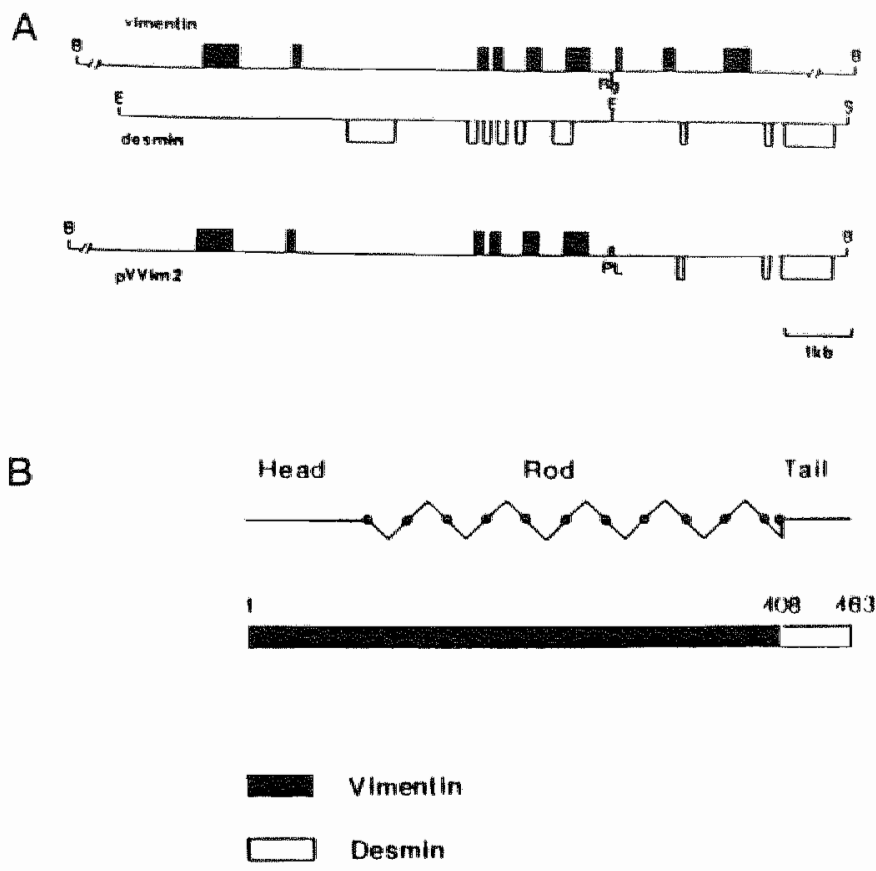

Figure 1: A] Physical map of the hamster vimentin gene, the hamster desmin desmin gene and the hybid gene pVVim2. Bars represent exon sequences; Bamlil, BgllI, EcoPI, and StuI restriction sites are indicated as $B, B g, E$ and $S$, respectively: PL represents the polylinker of the pUC19 vector. B/ Schematic representation of the hybrid protein encoded by the pWVim2 gene.

\section{Transgenic mice}

For the generation of transgenic mice the pVVim2 hybrid gene was excised from the vector and injected into the most accessible pronucleus of fertilized mouse eggs. Three transgenic mice were obtained (Nos. 32, 34 and 44). Southern blot analysis of tail DNA showed that the three transgenic founders had incorporated multiple copies of the gene in a head-to-taill arrangement (Figure 2). None of the transgenic mice showed any abnormalities. Two founders (Nos. 32 and 44 ) transmitted the pVVim2 gene to their offspring. Southern blot analysis indicated that founder No. 44 was mosaic for the pVVim2 gene, as its offspring showed a much stronger hybridization signal. This was also confirmed by immunofluorescence studies on tissue sections (see below) ".

\section{Tissue-specific expression}

The expression of the pVVim2 protein was analyzed by the indirect immunofluorescence 


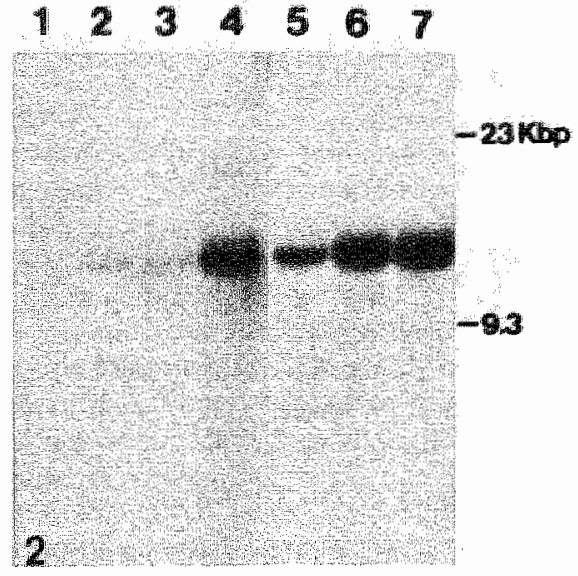

Figure 2: Southern blot analysis of tail DNA from transgenic mice. $8 \mathrm{~kg}$ of DNA was digested with Stull, run on $0.6 \%$ agarose gel, transterred to nitrocellulose and hybridized with the desmin-specific probe AAB5; Stul cleaves once in the pVVim2 fragment and in a head-to-tall tandem alray of pVWim2 copies it generates a single hybridizing fragment of unit size; in all transcenic mouse lines muttiple copies of $\mathrm{p}$ WWim2 were integrated. Lane 11 DNA from a control mouse; lane 2) DNA from founder No. 32; lane 3) DNA from offspring of founder No. 32; thane 4) DNA from founder No. 34; ane 51 DNA from founder No.44; lanes 6) and 7) DNA from offspring of founder No. 44. (pKer; data not shown). In frozen sections from transgenic spleen nearly all cells stain with pDes, whereas in spleen from control mice only smooth muscile tissue of blood vessels are positive (data not shown). In testis of transgenic mice Leydig cells and Sertoli cells express the hybrid protein (Fig. 3h). In liver of pVVim2 transgenic mice. Kupffer cells which express vimentin stain strongly with the pDes serum (Fig. 3k). A comparison of liver sections from founder No. 44 with liver sections from its positive offspring confirmed the mosaic character of transgene integration in founder No. 44; only Kupffer cells in distinct liver segments react. with the pDes antiserum in the founder (Fig. $3 \mathrm{~m}$ ), whereas in positive offspring all Kupffer cells stain with this antibody.

\section{Identification of the pVVim2 mRNA and protein in vitro}

Ear-shell fibroblasts from transgenic founder No. 32 were immortalized by SV 40 , and the cells were cloned and used for RNA and protein analysis. It appears that the hybrid pVVim 2 protein is present in a filamentous network with normal IF appearance (Figure 4). Double-label immunofluorescence studies of the same cells with desmin and vimentin antibodies show that the hybrid protein is colocalized with the endogenous vimentin filaments (Fig. 4c, d).

RNA was isolated from these cell lines and analyzed by Northern blot (Figure 5). Clearly. only in fibroblastic cell lines derived from a pVVim2 transgenic mouse was an mRNA of the appropriate size $(2.2 \mathrm{kbp})$ observed with the desmin probe $\times 54$, whereas fibroblasts from control mice were nonreactive. Hybridization with the vimentin-specific probe $\mathrm{E} 49$ 

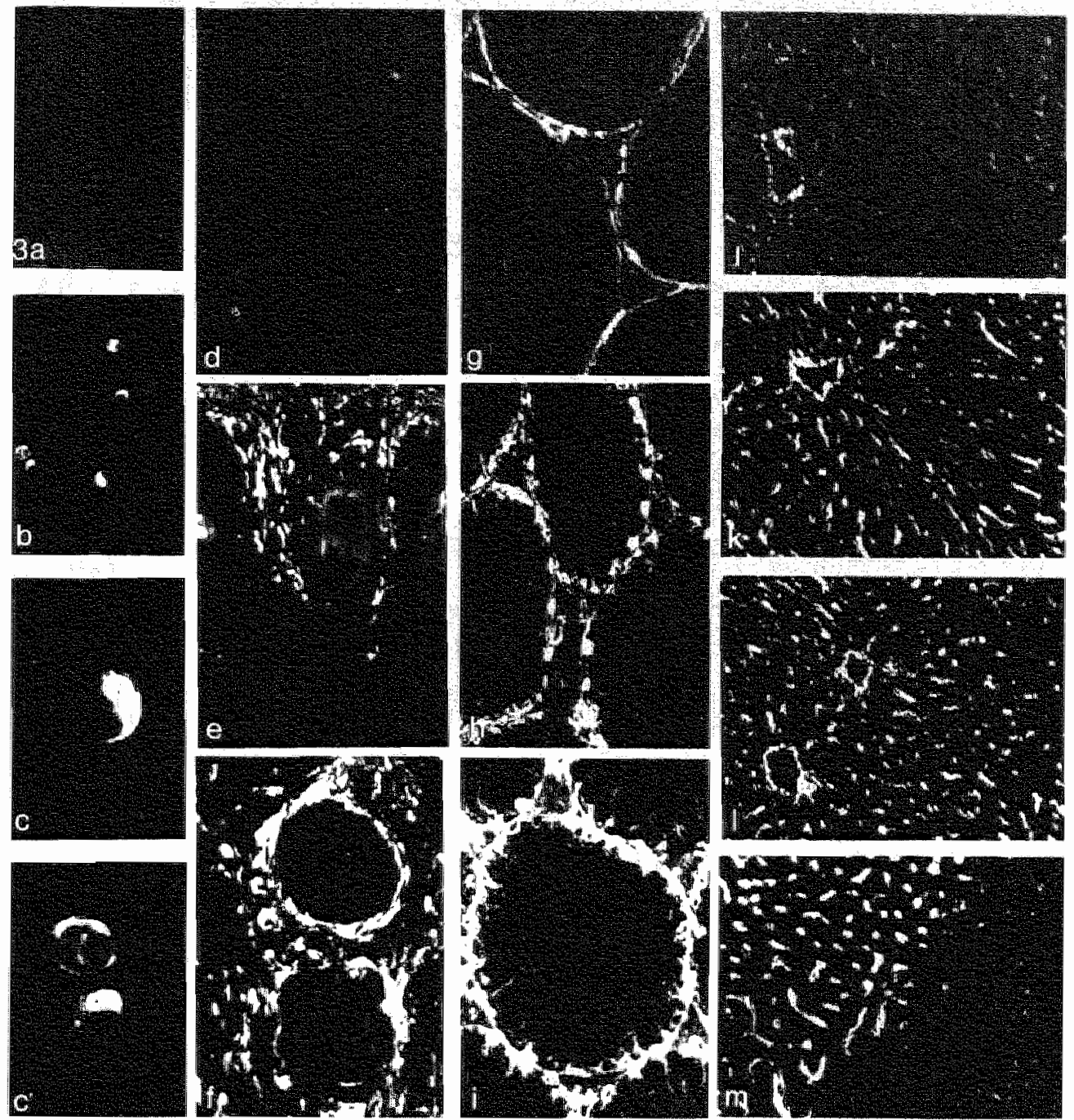

Figure 3: Indirect immunofluorescence studies. Immunofluorescence was performed on blood smears la-

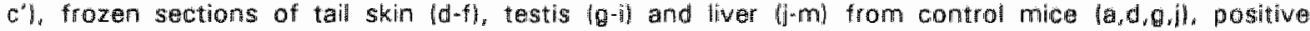

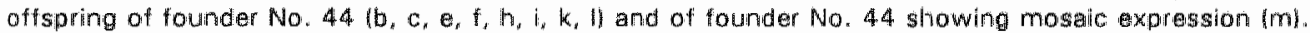
Sections depicted in panels a-h, $\mathrm{k} k$ and $\mathrm{m}$ are reacted with the pDes antiserum; and 1 are stained with the pVim antiserum. Note that incubation of the smears and tissues from control mice with a polyclonal desmin antiserum does not show any staining of blood cells (a) or epidermis (d). Staning is exclusively seen in celis known to express desmin, i.e., smooth muscle cells of blobd vessel walls lif or myoid cells surrounding the seminiferous epithellum of the testis fal. In mice hab boring the pWvim2 transgene, cells normally expressing only vimentin, f.e. macrophages $(b, c)$ fibroblasts $(e, 1)$, Leydig ciells and Sertoli cells in testis $(h)$, and Kupffer cells in liver $[k, m)$, now also express the pVim2 protein, as visualized with the pDes antiserum. For comparison the frozen sections were also incubated with pvim fill. Mosaic expression can be seen in the liver section depicted in $\mathrm{m}$. 

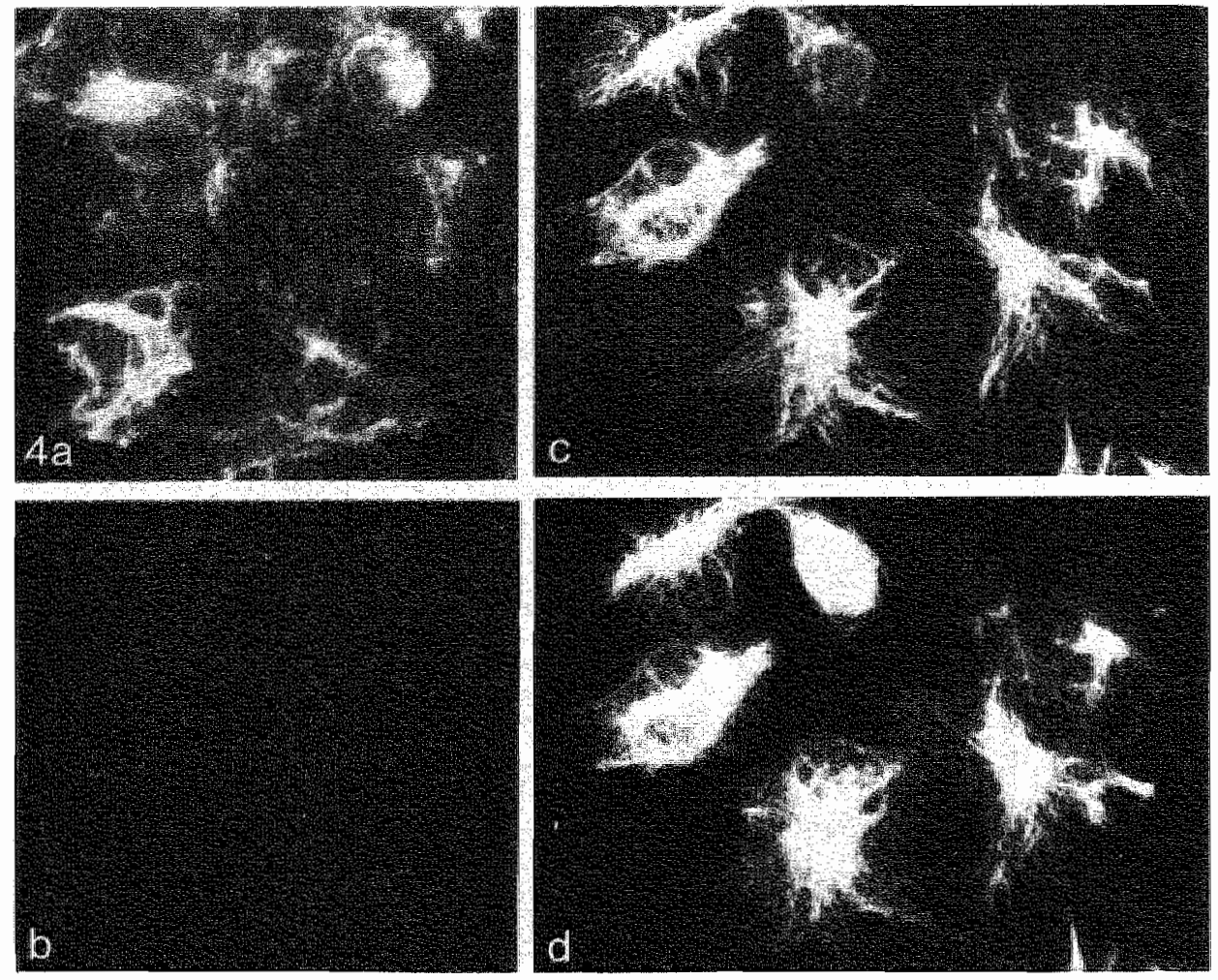

Figure 4: Double-label immunofluoresicence staining of transformed fibroblasts from transqenic mouse No. 32. Colocalization of pVVim2 protein and vimentin filaments is shown by staining with the polyclonal vimentin antibody (pVim; cl and the monoclonal desmin antibody (RD30\%; d). Fibiroblasts from control mice react with pim (a) and not with RD301 [b].

showed the presence of the $2.0 \mathrm{kbp}$ long mouse vimentin mRNA in cell lines from both control and transgenic mice.

The hybrid gene is expressed at a llevel similar to that of the endogenous vimentin. Comparison of MRNA levels in fibroblasts from transgenic and control mice (Figure 5 , compare lanes 1 and 2 to lane 3l clearly shows that the expression of the endogenous vimentin mRNA is not influenced by pVVim 2 expiression.

\section{Identiflcation of the pVVim2 protein}

The immunohistochemical data were further substantiated by biochemical identification of the pVVim 2 protein. Protein analyses by Western blotting were performed on the SV 40 transformed fibroblastic pVVim2 positive cell clones which were also used for RNA analyses. In addition the in vivo synthesized pVVim2 protein was charact-erized. We chose lens cell tissue which normally expresses vimentin [23].

Western blots of SDS-polyacrylamide gels were incubated with a monoclonal antibody to desmin (RD301), and with a monoclonal antibody specific for vimentin (RV202). The epitope recognized by 200301 is located in the tail domain of desmin encoded by the last three exons of the hamster desmin gene [32]. Lysates from BHK21/C13 cells and a crude desmin preparation from mouse muscle were used as positive controls. SV40-transfor- 

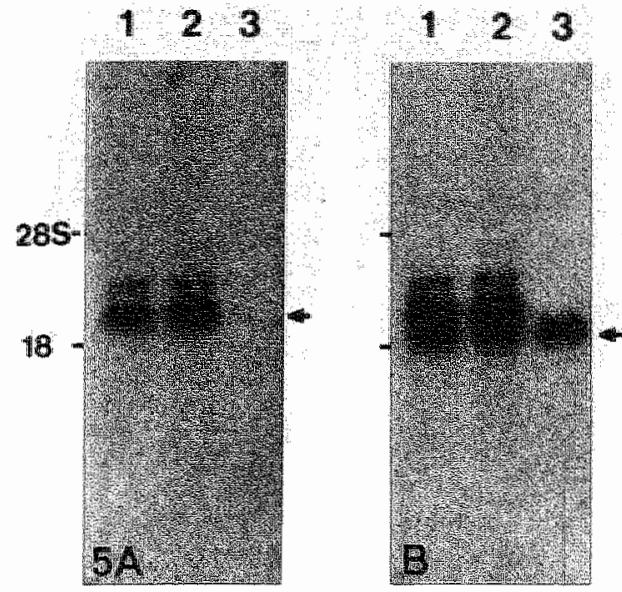

Figure 5: Northern blot analysis of ANA from fibroblastic cell lines derived from pWVim2 trans. genic mice. $15 \mu \mathrm{g}$ total RNA was electrophoresed on a $1 \%$ agarose gel, transferred to nitrocellulose and hybridized with desmin-specific probe $\times 54$ lpanel Al, and with the vimentin-specific pirobe $E 49$ lpanel Bl. Lanes 1: and 2) RNA isolated from two independent pDes positive cell lines derived from founder No. 32; lane 3) RNA isolated from a pDes negative control cell line. med fibroblasts and lenses from control mice were used as negative controls. The results (Figure 6) clearly show the presence of the pVVim2 protein with an apparent molecular mass of $57 \mathrm{kDa}$ in the transgenic fibroblastic cell lines and lens cells. In skeletal muscle tissue no pVWim2 or vimentin protein was detacted (Fig. 6. lane 31. Since we used different antibodies to detect the hybrid protein it seams unlikely that this negative reaction is caused by masking of epitopes due to conformational change during myogenesis. This was confirmed by immunohistochemical analyses of muscle tissue (data not shownl. Both striated and smooth muscle cells from different organs were stained with monoclonal and polyclonal antibodies against vimentin and desmir. In transgenic mice the desmin staining pattern was similar to that in control mice. No staining with the vimentin antibodies was observed in striated muscle cells indicating that both pVVim2 and vimentin are mot axpressed in these cells. Smooth muscle cells which do not express vimentin in control mice also do not express pVVim2 or vimentin in transgenic mice.

\section{The pVVim2 expression level}

In order to determine the expression level of pVVim2, cytoskeletal fractions of eye lenses from control and transgenic mice (founders Nos. 32 and 44 ) were analyzed by onedimensional SDS-gel electro-phoresis (Fig. 7A). In lenses of offspring from founder No. 44

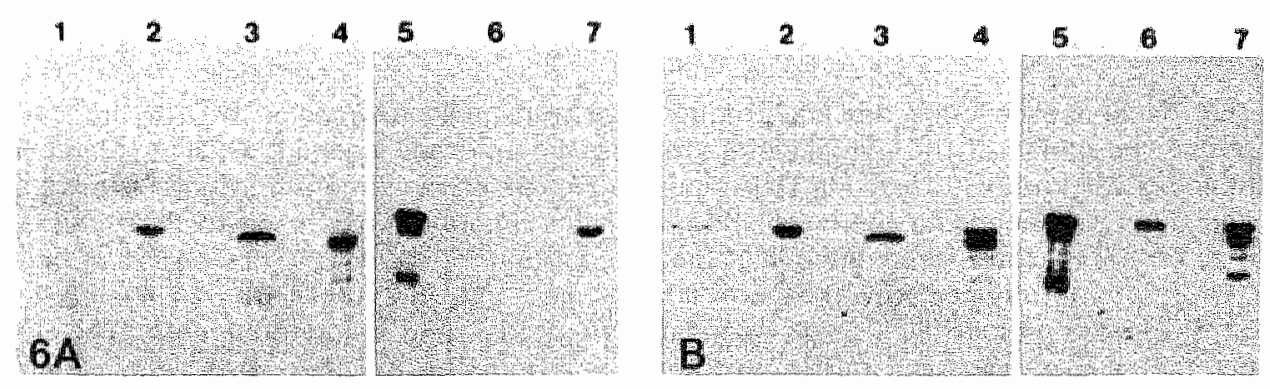

Figure 6: Biochemical characterization of intermediate fitament proteins from tissues of transpenic and control mice. Western blots prepared from tissue proteins were incubated with the monoclonal desmin antibody RD301 (panel A), and subsequenty with the monoclonal vimentiri antibody AV202 lpanel Bl. Lane 1 ) transformed fibroblasts: from control mouse; lane: 2) transformed fibroblasts from transgenic mouse No. 32; lane 3) muscie, only positive for desmin; lane 4) BHK cells, positive contral for desmin and vimentin; ane 5 ) eye lens from transigenic mouse $\mathbb{N o} .32$; lane 6 lens from control mouse; lane 7 ) BHK cells: adiditional protein bands below desmin represent characteristic if breakdown praducts. 


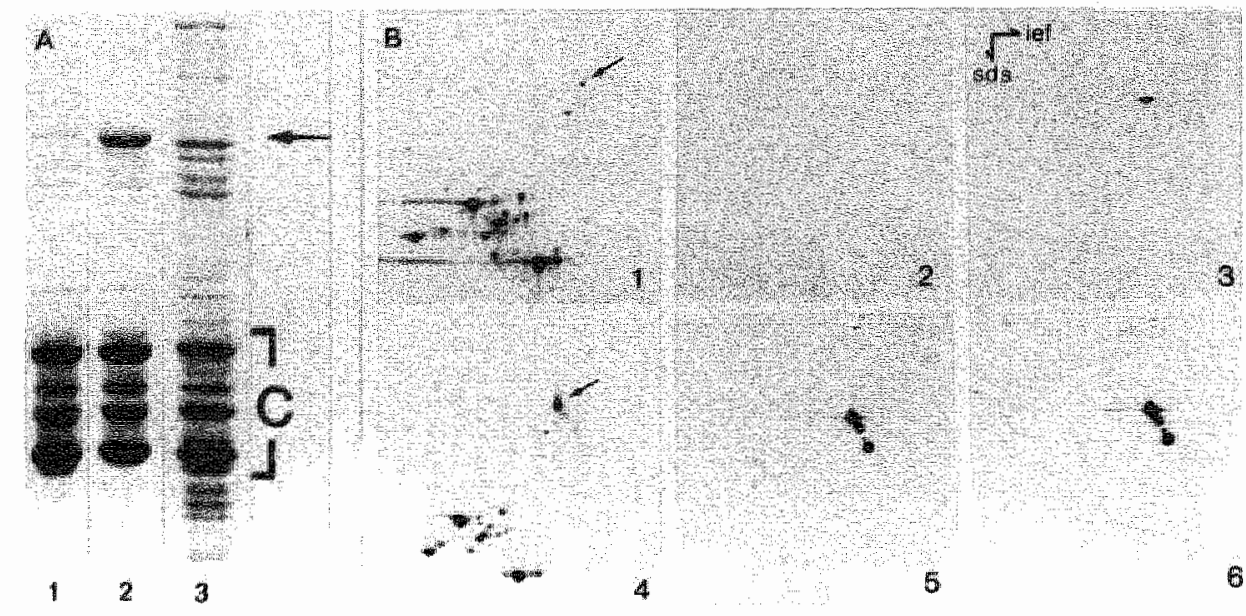

Figure 7: Biochemical characterization and analysis of expression levels of HF proteins from eye lenses of transgenic and control mice. A) Coomaste Brillant Blue (CBBI stainimg of one-dmensional SDS-gels of cytoskeleta preparations from control and transgenic mice. Lane 1) lens extract from control mouse; lang 2) lans extract from transquic mouse, derived from founder No. 44; lane 3 lens extract from transgenic mouse derived from founder No. 32. Arrow indicates pVVim2 protein and vimentin position. C: crystallin polypeptide chains serve as standards for the amount of protein applied onto the gel. B Total long extract of control $(1-3)$ and transgenic mice (4-6), analyzed by two dimensional gel electrophoresis and stained with CBB $(1,4)$ or immunoblotted $(2,3,5,6)$ and stained with the monoclonal desmin antibody MDS0 12,15$)$, and subsequently with the monoclonal vimentin antibody RV202 $3,6 \%$. Both mice were derived from founder No. 44. Arrows indicate If protein position. Additional spots on the blot represent characteristic If breakdown products.

high levels of IF expression were detected clearly exceeding vimentin expression in lenses from control mice. Lenses of offspring from founder No. 32 also showed elevated. although much less, if expression levels. 2D-gel electrophoresis analyses of total lens extracts from control and transgenic offspring from founder No. 44 confirmed these findings (Fig. $7 \mathrm{~B}$ ). Immunoblatting of 2D-gels positively identified the hybrid protein and vimentin which were not separated on these gels. Identical results were obtained with cytoskeletal preparations (data not shown).

\section{DISCUSSION}

In this paper we describe the construction and transgenic expression of a hybrid gene between the genes of the cytoskeletal proteins wimentin and desmin. A DNA fragment containing $3.1 \mathrm{kbp}$ of $5^{\prime}$ flaiking DNA and the $5^{\prime}$ part of the vimentin structural gene up to the 6 th exon, encoding the head and rod of the vimentin, was fused to the three last exons of the desmin gene encoding the tall portion of desmin. This chimeric gene, pVVim2, was introduced into the germ line of mice and its expression was analyzed at the MRNA and protein level using specific ONA probes and immunoreagents. The data show that a properly sized mRNA is transcribed from the pVVim2 gene. The pVVim2 mRNA is translated into a protein of the expected molecular mass.

Immunohistochemical analyses of tissue sections indicate that the expression pattern of the transgenic pVVim2 gene is indistinguishable from that of the endogenous vimentin. The expression levels differ in the two transgenic mouse strains investigated. Offspring mice from founder No. 32 expressed the hybrid gene at levels similar to the endogenous vimentin gene, whereas offspring from founder No. 44 expressed pVVim 2 to a signifi- 
cantly higher level. RNA analyses show that endogenous vimentin expression is not measurably influenced by transgenic pVVim 2 expression.

All the regulatory sequences required for the tissue specific expression of vimentin are included in the $9.2 \mathrm{kbp}$ BamHI-Bgll fragment, starting $3.1 \mathrm{kbp}$ upstream from the transcriptional initiation site. The immunofluorescent staining pattem with the polyclonal desmin antiserum (pDes), especially of transformed fibroblasts (Fig. 4) demonstrates that the pVVim 2 protein under these circumstances can assemble into filamentous structures. Double-label immunofluorescence studies which combine monoclonal antibodies RD 301 and RV2O2 with the pVim and pDes antisera, respectively, show that the vimentin containing filaments matched completely with the pVVim2 containing structures, strongly suggesting that pVVim 2 protein copolymerizes with vimentin and becomes a part of the vimentin skeleton. This is in agreement with cross-linking studies in which copolymerization has been shown between vimentin and desmin $[22,28]$. Since the pVVim 2 protein contains the vimentin a-helical domain and the desmin carboxy-terminus, which is supposed to protrude from the skeletal backbone [9], copolymerization between pVVim 2 and vimentin is not surprising.

Intermediate filament proteins are expressed in a developmentally regulated and tissuespecific fashion, and this pattern of expression has been conserved among vertebrate species. However, some differences which may relate to a slight divergence in the developmental pattern of a distinct cell lineage, have been noted [15]. This supports the view that intermediate filaments fulfill an important role in development. Furthermore, it suggests that alterations in highly conserved protein domains, which are supposed to be of crucial importance for proper functioning of IFs, are probably not tolerated. The amino acid sequence of the carboxy-terminal domain of vimentin is much more conserved among species than the sequence of the amino-terminal domain and approximates the conservation of the rad domain [34]. This is also abserved for desmin [19]. However, the carboxy-terminal regions of different classes of IF subunits have significantly diverged. This is suggestive for the importance of the carboxy-terminal region in IF-specific function. Recently, it has been shown that the carboxy-terminal domain of both vimentin and desmin can associate with lamin $B$ at the nuclear envelope 110,111 . Our results show that the presence of significant levels of $p V V / m 2$ protein in all vimentin-expressing cells does not interfere with normal mouse development. Preliminary results using transgenic mice in which desmin is expressed in a vimentin-specific fasllion also indicate that the expression of desmin in mesenchymal cells does not interfere with normal development. This suggests that, if vimentin fulfills an essential function in development, this function is not hampered by the coexpression of pVVim 2 or desmin.

Acknowledgements: We thank Anneloes Beenders, Esther Kornneef and Annemiete van de Kemp for technical assistance.

\section{REFERENCES}

1. Auffray C, Rougeon F. Purification of mouse immumoglobulin heawy chain mRNAs from total myeloma tumor RMA. Eur. J. Bioichem. 107, 303-314, 1980.

2. Bloemenda H, Lenstra JH. Dodemont H, Rametekers FCS, Gromeneld AA, Dunia I, Benedetti EL. SV4O-transfected hamster lens epithelial cells: a novel system for whe isolation of cytoskaletal messenger RNAs and their translation products. Exp. Eye Res. 31, 513.525, 1980.

3. Broers JLV, Carney DN, Klein Rot M, Schaart G, Lane EB, Wooijs GP, Ramaekers FCS. Intermediate flament proteins in classic and wariant types of small cell lung carcinoma cell tines: a biochemical and immunohistochemical anaiysis usinge a panel of monoclonal and polyclonal antibodies. J. Cell Sci. 83, 37-60, 1986.

4. Cuypers HT, Selten G, Quint W, Zilistra M, Robanus-Maandag E, Boelens W, Wan Wezenbeek P, Mellef $C_{n}$ Berns A. Murine leukemia wirus-induced T-cell Inmphomagenesis: integration of prowiruses in a distinct chromosomal region. Cell $37,141-150,1984$. 
5. Fisher $\mathbb{D Z}$, Chaudhary 1 , Biobel G. CDNA sequencing of nuclear lamins A and C reveals primary and secondary stucturat homology to intermediate flameni proteíns. Proc. Matl. Acad. Sci. USA. $23.6450-6454,1986$

6. Franke WW, Schirid E, Winter S, Osborn M, Weber K. Widespread accurrence of intermediate sized fitaments of the wimentin type in cultured cells from diwerse vertebrates. Exp. Cell Res. 123. $25-46,1979$.

7. Franke WW, Schmid $E$, Schiller DL, Whiter $S$, Jarasch ED, Moll $R$, Denk $H$, Jackson BW, llmensee K. Differentiation-related pattens of expression of proteins of intermediate-size fllaments in tissues and cultured cells. Cold Sping Harbor Symp. Obant. Bilol. 46, 431-453, 1982.

8. Geisher $N_{*}$ Kaufmann $E_{*}$ Weber $K$. Proten-chemical characterization of three structurally distinct domains along the prototilament unit of desmin $10 \mathrm{~nm}$ filaments. Cell $30,277.286,1982$.

9. Geister $N$, Weber $K$. Structural aspects of intermediate filaments. In: Cell and Mofecular Biology of the Cyciskekton. led. Shay Gl Plenum Press, New York, pp. 41-64, 1986.

10. Georgatos $\mathrm{SD}$, Blobel $\mathrm{C}$. Lamin $\mathrm{B}$ consititutes an intermediate filament attachment site at the nuclear envelope. $\mathrm{J}$. Cell Biol. 105, $117,-125,1987$.

11. Georgatos SD, Weber K, Geisler $N$, Blobel G. Binding of two desmin derivatives to the plasma membrane and the nuclear envelope of avian erythrocytes: evidence for a conserved sitespecificity in intermediate flament-membrane interactions. Prac. Natl. Acad. Sci. USA 84, 67806784,1987

12. Kaumann E, Weber $K$, Geisler $N$, Intermediate filament forming ability of desmin derivatives lacking either the amino-terminal 67 or the carboxy-terminal 27 residues. J. Mol. Biol. 185, 733742,1985

13. Lazarides E. Intermediate filaments: a chemically heterogeous, developmentally regulated class of proteins, Annu. Rev. Biochem. 51,219-250, 1982.

14. McKeon FD, Kirschner MW, Caput D. Homologies in both primary and secondary structure between nucllear envelope and intermediate fllament proteins. Nature 319, 463-468, 1986.

15. Ngal $\mathrm{J}$, Bond VC, Wold BJ, Lazarides E. Expression of transfected wimentin genes in differentiating murine erythroleukemia celis revealed divergent cis-acting regulation of awian and mammalian whentin sequences. Mal. Cell. Biol. 7, 3955-3970, 1987.

16. Osborn M. Weber $K$. Intermediate lilaments: cell type-specific markers in differentiation and pathology. Cell 31, 303-306, 1982.

17. Pleper FA, Slobbe RL, Ramackers FCS, Cuypers HT, Bloemendal H. Upstream regions of the hamster desmin and vimentin genes regulate expression during in vitro myogenesis. EMBO $\mathrm{J} .6$, $3617-3618,1987$.

18. Cuax W, Vree Egberts $W$, Hendriks $W$, Qwax-Jeuken $Y$, Bloemendal $H$. The structure of the vimentil gene. Cell $35,215-223,1983$.

19. Quax W, Van den Heuwel $A$, Vree Equerts $W$, Quax-Jeuken $Y$, Bloemendal H. Interemdiate filament cDNAs from BHK-21 cells: demonstration of distinct genes for desmin and wimentin in all vertebrate classes. Proc. Natll. Acaid. Sci. USA 81, 5970-5974, 1984.

20. Quax W, Van den Broek L. Vree Egberts W, Ramaekers F, Bloemendal H. Characterization of the hamster desmin gene: expression and formation of desmin hements in fonmusicle cells after gene transfer Cell 43, 327-338, 1985 .

21. Quax.Jeuken W, Quax W, Bloemendal H. Primary and secondary structure of hamster vimentin predicted from the nucleotide sequence. Prac. Natl. Acad. Sici. USA 80, 3548-3552, 1983.

22. Qublan RA. Franke WW. Heteropolymer fliament of wimentin and desmin in vascular smooth muscie tissue and cultured baby hamster kidney cells demonstrated by chemical cross-linking. Proc. Natl. Acad. Sci. USA 79, 3452-3456, 1982.

23. Ramaekers FCS, Osborn M, Schmid E, Weber K, Bloemendal H. Franke WW. Identification of the cytoskeletal proteins in lens-forming cells, a special epithelloid cell type. Exp. Cell Res. 127, 303327,1980

24. Ramaeker's FCS, Put\$ JJG, Moesker O, Kant A, Huysmans A, Haag D, Jap PHK, Herman C, Vooijs GP. Antibodies to intermediate fitament proteins in the immunohistochemical identification of human tumours: an overwiew. Histochem, J.15,691-713, 1983.

25. Ramaekers FCS, Verheiten RHM, Moesker D, Kant A, Vooils GP, Herman CJ. Mesodermall mixed tumor: diagnosis by analysis of intermediate filament proteins. Am. J. Surg. Pathol. 7 , 381-385, 1983.

26. Alttling $S R$, Baserga $R$. Functional analysis and growth factor regulation of the human vimentin promoter. Mol. Cell. Biol, 7, 3908-3915, 1987.

27. Roop DR. Steinert PM. In: Cellular and Molecular Biology of the Cytoskeletory. led. Shay WW Planum Press, New York, pp. 69-83, 1986.

28. Steinert PM. Idler WW. Cabrat F, Gottesman MM, Goldmam RD. Prac. Nath. Acad. Sci. USA 78, 
3692-3698, 1981.

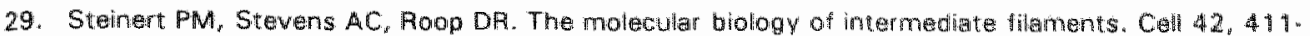
419. 1985.

30. Traub P, Vorgias CE. Irwolvement of the N-terminal polypeptide of wimentin in the fomation of intermediate filaments. $\mathrm{d}$. Cell Sci. 63,43-67, 1983.

31. Traub P. htermediate faments, a Reviow. Springer Verlag. Bevin, 1985.

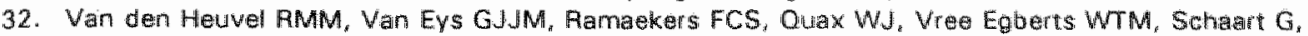
Cuypers HTM, Bloemendal H. Intermediate filment formation after transfection with moditied hamster vimentin and desmin genes J. Cell Sci. 88,475-482, 1987.

33. Virtanen 1, Lehto V.P, Lehtonen E. Vartio T, Stenman S, Kurki P. Wager O, Small JV, Bradiey RA. Expression of intermediate filaments in cultuted cels. J. Cell Sci. 50, 45-63, 1981.

34. Zehner ZE, Li U, Roe BA. Paterson BM, Sax CM. The chicken vimentin gene: nucleotide sequence, regulatory elements, and comparison to the hamster gene, J. Biol. Chem. 262,8112.8120, 1987. 



\section{CHAPTER 6}

\section{TRANSGENIC EXPRESSION OF THE \\ MUSCLE-SPECIFIC INTERMEDIATE FILAMENT PROTEIN DESMIN IN NONMUSCLE CELLS}

F.R. PIEPER, G. SCHAART, P.J. KRIMPENFORT, J.B. HENDERIK, H.J. MOSHAGE, A. VAN DE KEMP, F.C.S. RAMAEKERS, A. BERNS and $H$. BLOEMENDAL

The Journal of Cell Biology 108, 1009-1024, 1989 
The coding region of the hamster desmin gene was fused to the $5^{\prime}$ flanking sequences of the hamster vimentin gene and introduced into the germ line of mice. The expression of this intermediate filament gene construct (pVDes) was analyzed at the RNA and protein level in transgenic mice as well as in fibroblast cell lines and primary hepatocyte cultures derved from these mice. In all transgenic mice, the pvDes-encaded protein was coexpressed with mouse wimentin in a tissue-specific fashion and was indistinguishable from normal hamster desmin. Culturing of transgenic hepatocytes induced desmin expression indicating that $3.2 \mathrm{kbp}$ of the vimentin gene 5 ' region regulates both tissuespecific and tissue culture-induced intermediate filament protein expression. Immunohistochemical staining and double-label immunoelectron microscopy of cultured transgenic fibroblasts showed that the pvDes protein assembled into intermediate ffilaments which colocalized with the mouse vimentin filaments. Endogenous vimentin RNA levels were not influenced by high-level pvDes expression. The coexpression of desmin and vimentin in nonmuscle cells did not result in detectable developmental, morphological, or physiological abnormalities.

\section{INTRODUCTION}

Intermediate filaments (IFs) represent a unique group of cytoskeletal structures that occuir in the cytoplasm of virtually all mammalian cells. The expression of the different classes of IF subunits is regulated in a tissue-specific and developmentally regulated fashion. Generally, cytokeratins are expressed in cells of epithelial origin while neurofilaments are expressed in neuronal cells, glial fibrillary acidic protein in astrocytes, desmin almost exclusively in striated and most smooth muscle cells, and vimentin mainiy in cells of mesenchymal origin [58, 59,64]. The expression of nuclear lamins, which are part of the If multigene family, is also cell type-specific and developmentally regulated [12, 29,61]. The highly conserved specificity of If subunit expression during development suggests that each type of subunit plays an important role in cellular differentiation.

On the basis of gene structure and sequence data, the If subunits have been divided into four subfamilies. Vimentin [47], desmin [48], glial fibrillary acidic protein [40], and possibly a recently described neuroflament protein [39] display a high degree of homology and constitute one subfamily of proteins (type III subunits). Like the other IF proteins, they have a conserved a-helical domain of -310 amino acid residues, flanked by nonhelical amino-terminal and carboxy-terminal domains of variable length and sequence $112,22,58,59,641$. In view of the highly-specific expression pattern of each if subunit, it may be assumed that their variable terminall regions at least partly determine the specific properties that are needed in different cell types during various stages of dewelopment $[23,38,58]$.

The vimentin expression pattern is relatively complex. During embryogenesis, vimentin is the first of the nonepithelial subunits to be expressed $[18,30]$. The appearance of the cell typo-specific If subunits is often preceded by vimentin expression, and in certain cases coexpression with the other types of IF is observed $[9,19,37,56,57,64,65]$. When non-mesenchymal cells are dissociated from tissues and brought into culture, induction of vimentin synthesis often occurs $[15,64]$. This is mostly accompanied by the continued coexpression of the tissue-specific If protein, but in some cases only vimentin expression remains 16,17$]$. The level of vimentin expression is growth regulated and can be stimulated by some growth factors 111,541 . This complex expression is mediated by multiple regulatory elements in the $5^{\prime}$ flanking sequence of the vimentin gene $[46,54]$.

In cultured cells, the study of cell type-specific regulation and function of IF expression is necessarily limited. The phenomenon of tissue culture-induced vimentin expression is not understood. The observations, that some cell lines do not express IFs [27, 41, 64], and 
that disruption of IFs does not affect growth or morphology of cultured cells [21,34, 421, indicate that IFs -at least in witro-do not fulfill an essential cellular function 113 ].

Transgenic mice. which have proven to be useful in the study of tissue-specific gene expression [for review see: 44], provide a better system to study If gene regulation and funtution. Our approach was to change the normal IF expression pattern by introducing an IF gene construct into the germ line of mice composed of the $5^{\prime \prime}$ flanking region of the vimentiry gene and the complete coding region of the desmin gene. Transgenic mice, primary cell cultures, and cell lines derived from these mice were analyzed for the pattern and levels of desmin and vimentin expression.

\section{MATERIALS AND METHODS}

\section{Plasmid construction}

For ccnstruction of the pVDes gene, the $0.7 \mathrm{kbp} \mathrm{Hpall-BamHll}$ fragment from the hamster desmin gene (from +25 bp to +700 bp relative to the cap site [48]) was subcloned into an Accl-BamHI-digested pUC19 plasmid. The $3.2 \mathrm{kbp}$ BamHI-ECoRl from 4700 to +3.900 ) and the $3.4 \mathrm{kbp}$ EcoRI-Stul (from +3.900 to +7.300 ) desmin fragments were ligated immediately $3^{\prime}$ to this fragment, thereby generating a complete desmin gene without $5^{\prime \prime}$ sequences upstream of the Hpall site at $+25 \mathrm{bp}$. In this construct, $60 \mathrm{bp}$ of $5^{\prime}$ - and 775 bp of $3^{\prime}$ untranslated sequences (including the "poly $A^{\text {"l }}$ signal) are present. The $3.2 \mathrm{kbp}$ vimentin promoter region (ranging from $-3,100$ to +101 relative to the vimentin cap site) was isolated as a Hindlll fragment by ligating the $3.45 \mathrm{kbp}$ BamHIEcoRI fragment from p3.1VimCAT $[46]$ into an ECORI-BamHI-digested pUC19 plasmid. and subsequent partial HindIII digestion of this clone. This vimentin $5^{\prime \prime}$ region was ligated into the HindIII site of the pUC19 polylinker of the complete desmin gene in the $5^{r}-3^{*}$ orientation. The resulting construct (pVDes) contains some additional base pairs from the pUC19 polylinker between the HindIII and the Acci site. To facilitate removal of plasmid sequences before microinjection, the BamHI site in the first intron of desmin was removed by filling in and subsequent blunt end ligation after partial BamHI digestion.

\section{Generation and identification of transgenic mice}

Transgenic mice were generated by pronuclear microinjection as described previously 136]. Plasmid sequences were removed by BamHI (5\%, complete) and EcoRI (3', partial) digestion, leaving a $10.5 \mathrm{kbp}$ IF hybrid gene. This was isolated and purified by preparative gel electrophoresis and electroelution, dissolved in ultrapure water, and dialyzed against $10 \mathrm{mM}$ Tris-HCl (Merck, Darmstadt, FRG), $0.1 \mathrm{M}$ EDTA (Merck), PH 7.4. The DNA concentration was adjusted to $4 \mu \mathrm{gg} \mathrm{ml}^{-1}$, and \pm 200 pVDes copies were injected. Several weeks after birth of animals that had developed from microinjected eggs, tail DNA was isolated and analyzed by Southern blotting. Briefly, equal amounts $(10 \mu \mathrm{g})$ of total genomic DNA of each mouse was digested with the appropriate restriction enzyme(s), run on a $0.6 \%$ agarose gel, and transferred to nitrocellulose. The filter was hybridized to ${ }^{32} \mathrm{p}$ labelled probes (see below) and washed as described [5]. The number of integrated pVDes copies was determined by Sowthern blot analysis of serial dilutions of tail DNA, using the vimentin-specific probe E49, and subsequent densitometric scanning of the autoradiographs. pVDes hybridization signals were compared to those of the single copy mouse vimentin gene of serial dilutions of the pVDes plasmid. 
Total cellular RNA was isolated from tissues and cultured cells by the LiCl-urea method 111. Primer extension analysis on total cellular RNA from ear fibrablast cell lines was performed as described 124 (procedure 2)], using a 21 -mer $5^{\circ}$ desmin primer $15^{*}$. GGAGGCAGCGGGCAGGCAGCCC-3'; from + 25 to +46 relative to the transcription initiation sitel. For Northern blotting, 10, 15, or $20 \mu \mathrm{g}$ RNA samples were glyoxylated. fractionated on a $1.2 \%$ agarose gel, and transferred to Highbond- $N$ (Amersham International, Amersham, UK]. Hybridization was performed as described [5]. A 350 bp hamster desmin Sau $3 \mathrm{~A}$ fragment in $M 13$ (X5.4), covering a region from 25 bp of exon 8 to $120 \mathrm{bp}$ into the $3^{\prime}$ untranslated region, was used as desmin probe $[46,48]$. A 520 bp hamster vimentin Sau3A fragment in $M 13$, ranging from -150 to +370 bp relative to the cap site, was used as vimentin probe $[46,47]$. As an actin probe, we used a $1.25 \mathrm{kbp}$ Pstl hamster actin CDNA fragment $\left[81\right.$, which hybridizes to $a-B_{*}$, and $r$-actin. Densitometric scanning was performed on autoradiographs exposed for different times.

\section{Cell culture}

Ear fibroblast cell lines were established and cultured as described [3].

Mouse hepatocytes were isolated and cultured using the hepatic portal perfusion method as described 132, 33], with the following modifications. Instead of Hank's solution. Williams E medium (FIow Laboratories Inc. McLean, VA, USA) supplemented with 2.5 IM EGTA (Merck) was used. Hepatocytes were cultured in Williams E medium supplemented with $10 \%$ fetal calf serum (FCS; Flow Laboratories), $2 \mathrm{mM}$ L-glutamine (Flow

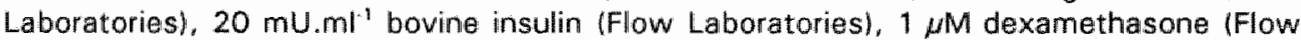
Laboratories), and antibiotics $\left(25 \mu \mathrm{g} . \mathrm{ml}^{-1}\right.$ fungizone, $100 \mu \mathrm{g} \cdot \mathrm{ml}^{-1}$ vancomycin, and 50 $\mu \mathrm{g} . \mathrm{ml}^{-1}$ gentamycin (all obtained from Flow Laboratories)).

\section{Gell electrophoresis and immunoblotting}

Cytoskeletal preparations of eye lens and cultured cells were obtained as described [35]. One- (1D) and two-dimensional (2D) SDS-gel electrophoresis and immunoblotting procedures have also been described previously $[4]$.

\section{Immunohistochemical analysis}

Single- and double-label indirect immunofluorescence analyses of frozen tissue sections and cultured cells were performed as described previously $[36]$. In the underlying study, however, muscle tissue sections were pretreated with $0.5 \%$ Triton $X-100$ (BDH Chemicals Ltd., Poole, UK) in PBS before incubation with the first antibodies. The following polyclonal and monoclonal antibodies were used:

1. An affinity-purified polyclonal rabbit antibody (pKer) raised against human skin keratins, which reacts with virtually all epithelial tissues [511].

2. An affinity-purified polyclonal rabbit antibody (pVim) to vimentin [51].

3. A pollyclonal rabbit antibody (pDes) to desmin [52].

4. The monoclonal antibody RV202 to vimentin [4].

5. The monoclonal antibody RD301 to desmin [4].

6. The monoclonal antibody RCK 102 to human cytokeratins 5 and 8 [53]. 
A

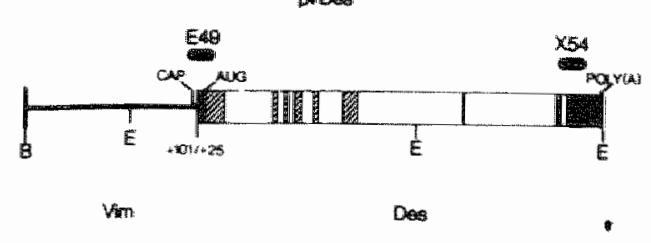

B

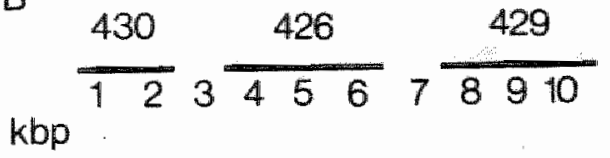

$9.4-$

$65-$
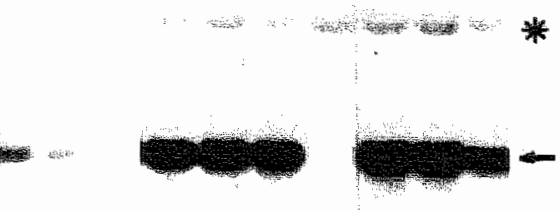

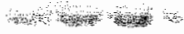

$43-$

Figure 1: Al Schematic representation of the If gene construct $p$ VDes (not drawn to scale). The line on the ieft represents the vimentin gene $5^{\circ}$ flanking region from $-3,100$ to +101 . relative to vimentin cap sitel. Bar represents the desmin gene with black regions indicating the dssmin $5^{\circ}$ - and $3^{\prime}$-untranslated secuences, hatched regians indicating exons, and open regions indicating the imtrons. Prostions of the vimentinspecific (E49) and desmin-specific $(\times 54)$ probes are indicated. E: EcoRl restriction site; 8 : BamHl restriction site. B) Southerm blot analysis of tail DNA from mice transgenic for pVDes. I 10 pg of DNA was digestrel with ECoRl. Mybridization was performed with the vimentin probe E49. Asterisk indicates posi-tion of the $8.5 \mathrm{kbp}$ EcoRI fragment from the single copy mouse vimentin gene. Arrow indicates position of the $5.95 \mathrm{kbp}$ EcoRl frament from pVDes. lane 1) DNA from offspring of tounder 430; lane 21 DNA from lounder 430; lanes 3 and 71 DNA from control mice: lanes 4 and 5) DNA from offspring of founder 426; lane 61 DNA from founder 426: lanes $B$ and 91 DNA from offspring of founder 429 ; lane 1 10) DNA fram founder 429.
Immunoelectron microscopy

Transformed fibroblasts from control and transgenic mice were grown on Thermanox coverships ILux, Lab-Tek Div., Mites Laboratories inc., Napervili, IL. USA), coated with fibronectin by a 30 min incubation with a crude prepa ration from human serum. Cells at $\pm 75 \%$ confluency were washed with double Hanks' buffer and converted to cytoskeletons by extraction for 2.5 min at room temperature with a buffer $(\mathrm{pH} 7.2)$ containing $0.5 \%$ Triton $\mathrm{X}-100$ [63], and fixed in buffered $0.5 \%$ paraformaldehyde (Merck) containing $0.3 \%$ Triton $x-100(\mathrm{pH} \mathrm{7.2).} \mathrm{The} \mathrm{cells} \mathrm{were}$ processed for immunogold labelling and electron microscopy essentially as described by De Mey 171 , and as in AuroProbe EM product information (Janssen Pharmaceutica, Beerse, Belgium). To reduce background staining the coverslips were preincubated for 20 min with a TBS solution (pH 8.2) containing $10 \%$ normal goat sarum and $0.1 \%$ BSA. The monoclonal and polyclonal antibodies were diluted in a similar buffer containing $1 \%$ normal goat serum and $0.1 \%$ Tween 20 isigma Chemical Company. St. Louis, USA). Washing buffers also contained $0.1 \%$ Tween 20 . Furthermore, the 5 $\mathrm{nm}$ and $10 \mathrm{~nm}$ antibody-coated colloidal gold preparations (Janssen Pharmaceutical were preabsorbed extensively on fibroblast cytoskeletons and diluted in Trisubuffer, $\mathrm{pH}$ 8.2. containing $1 \% \mathrm{BSA}$.

\section{RESULTS}

\section{Generation of transgenic mice}

We have demonstrated previously that the structural gene for hamster desmin and modifications thereof can be expressed after gene transfer into diffe. rent types of cultured nonmuscie cells resulting in assembly of newly synthesized protein into intermediate filaments [28, 48]. Regulatory sequences which control desmin expression are 

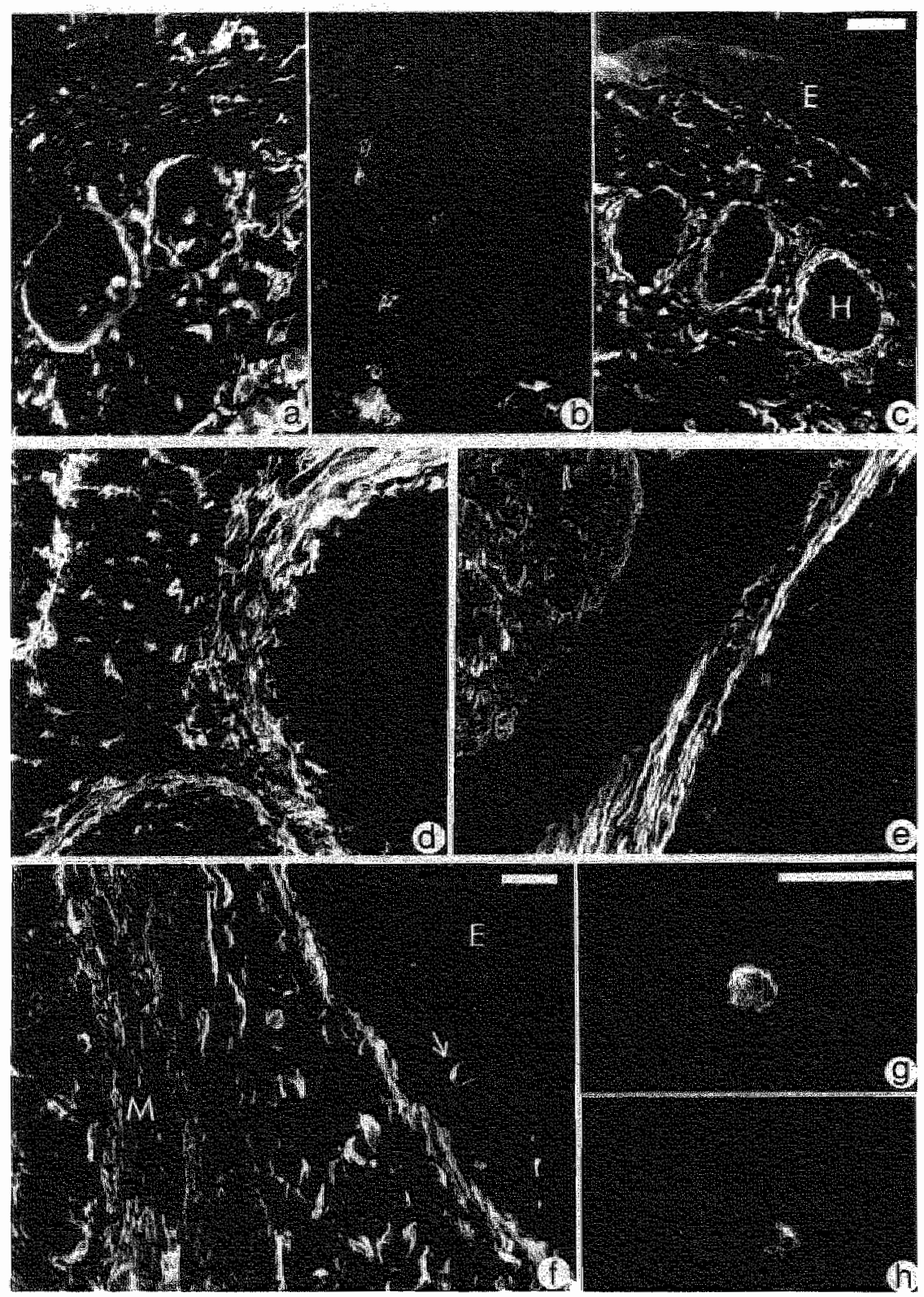

Figure 2: Expression of desmin and vimentim jin tissues from control and transgenic mice as detected with the indliect immunofluorescence assay tsing pDes and pVim. a-ch Tail skin from control (a, b) and

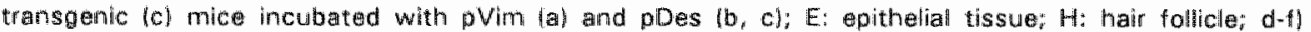
Esophagus from control $1 d$, el and transgenic (f) mice incubated with pvim (d) and pDes le, ll. Arrow indicates desmin-positive Langerhans cells; M: muscle tissue; E: epithelial tisswe; and h/ Cells from blood smears of transgenic mice showing a filamentous staining pattern after incubation whth pDes; ik striated muscle tissue of control $(i, j)$ and transgenic (k) mice incubated with pVim (i) and pDes (j, k). 

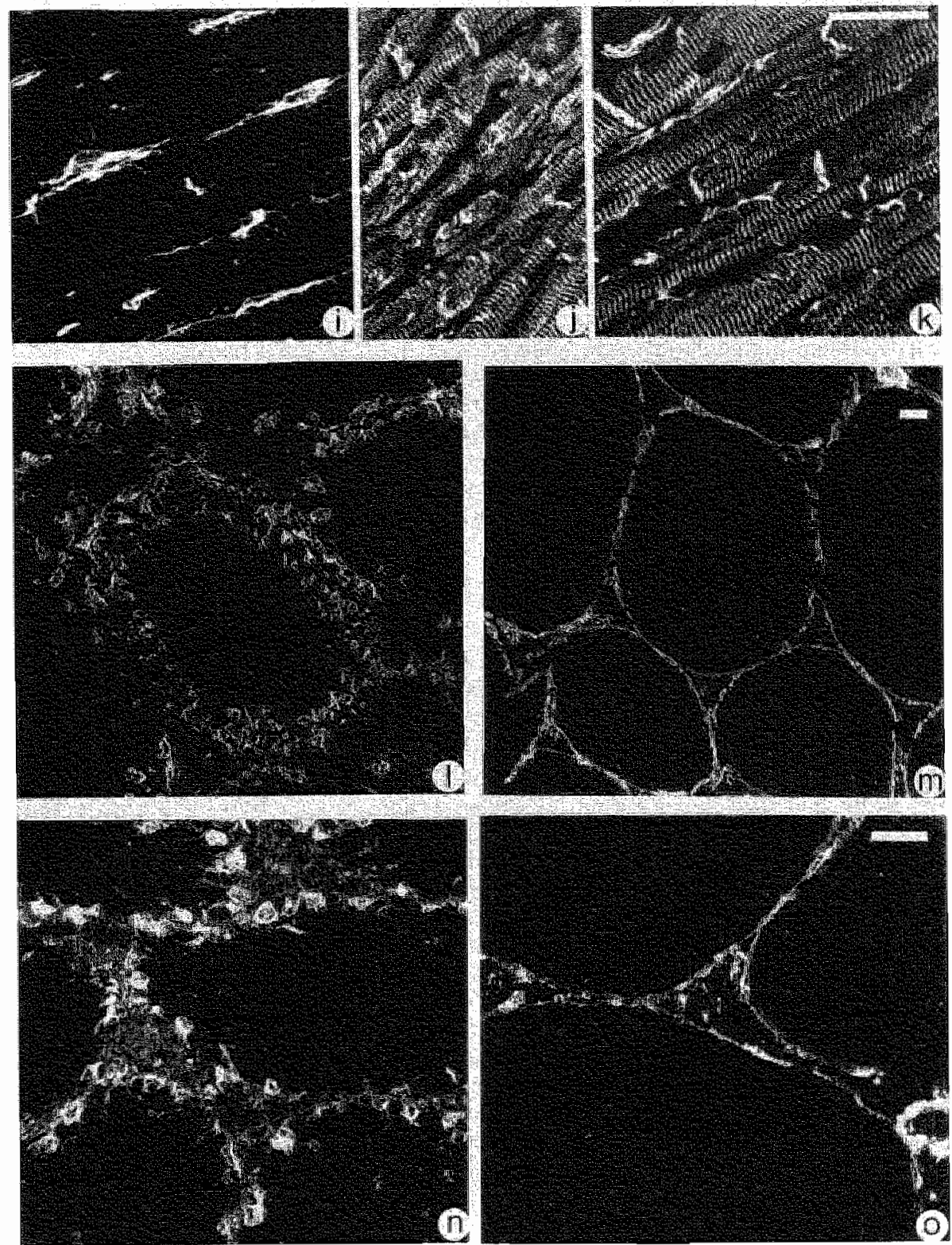

Note staining bf transgenic muscle and nonmuscle cells with pDes; 1 and of Testis tissue from control $h$,

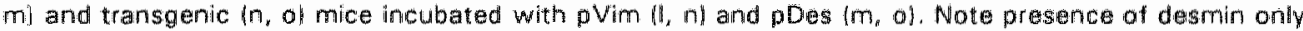
in myold cells and blood vessel smooth muscle cells in both control and transgenic testis tissues. Other tissues investigated include kidnev, liver, spleen, heart, brain, tongue, bledder, uterus, and prostate. Bars indicate $4 \mu \mathrm{m}$. 
located in a region between -89 and +25 relative to the transcription initiation site [46]. We removed these regulatory elements by deleing the complete 5 * flanking region of the desmin gene up to the Hpall site at position +25 , and replaced it by $3.2 \mathrm{kbp}$ of 5 'flanking sequences $(3,100$ to +101$)$ from the hamster vimentin gene (Fig. $1 \mathrm{~A}$ ). This upstream region contains regulatory elements that confer high lewels of vimentin expression in cultured cells and are instrumental in the down-regulation of vimentin expression during myogenesis [46]. The resulting IF gene construct pVDes $110.5 \mathrm{kbp}$ without plasmid sequences) consists of the complete coding region of the desmin gene and additional $5^{\prime \prime}$ and $3^{\prime \prime}$ untranslated regions, fused to $3.2 \mathrm{kbp}$ of vimentin upstream sequences (Fig. 1A; see Materials and Methods).

After removal of plasmid sequences the pVDes gene was injected into the most accessible pronucteus of fertilized mouse eggs. Southern blot analysis of tail DNA of mice born from these manipulated eggs showed that 5 of 32 mice had incorporated multiple copies of the construct into their genome in a head-to-tail tandem array. Three of these (strains 426,429 and 430 ) produced offsprings, all of which inherited the pvDes transgene (Fig. 1B). Southern blot analysis revealed no detectable rearrangements in the pVDes sequences (data not shown). Offspring from founders 426 and 429 contained -25 and 30 copies, respectively, whereas 430 and its offspring had incorporated only 3 pVDes copies. $F_{1}$ and $F_{2}$ analysis showed that integration had taken place into single loci.

\section{Tissue-specific pVDes expression}

The desmin expression pattern in tissue sections from transgenic mouse strains 426,429 and 430 and from control mice was analyzed by the indirect immunofluorescence technique, using polvclonal rabbit antisera directed against desmin (pDes), vimentin (p V im). and cytokeratins (pker) 151,521 . From transgenic mice 427 and 428 only tail sections were examined. From transgenic mouse strains 426,429 and 430 a number of tissues were analyzed and for each of these strains at least two male and female mice were used. Cells expressing vimentin but not desmin in tissues from control mice le.g., fibroblasts, endothelial cells, cartilage, Kupffer cells, macrophages, Schwann cells) displayed intensive staining in transgenic tissues after incubation with pDes and with pVim (Fig. 2). Occasionally, a filamentous staining pattern was observed, suggesting that the pVDes-encoded desmin had assembled into IFs (Fig. $2 \mathrm{~g}$, h). Epithellial tissues stained with pKer but not with pDes. In transgenic striated muscle tissue, connective tissue fibroblasts not only expressed vimentin (Fig. 2i) but also desmin, both in skelletal (Fig. 2k) and haart muscle (not shown). All five transgenic mice and their offspring (from 426, 429 and 430 i expressed pVDes in a vimentin-specific fashion. Surprisingly, in testis from the three transgenic mouse strains, Sertoli and Leydig cells, although expressing vimentin, deviated from all other tissues tested (listed in legend to Fig. 2) in that they did not contain detectable amounts of desmin (Fig. 21-o).

We did not observe any morphological effects of pVDes expression, nor did the transge. nic mice show detectable developmental or physiological abnormalities.

\section{Characterization of in wivo-synthesized pVDes protein}

To identify biochemically and characterize the in vivo-synthesized pVDes protein, we analyzed eye lens extracts from transgenic mouse strains 426,429 and 430 . Eye lens tissue has the advantage of expressing high levels of vimentin in the absence of desmin 1501. 1D SDSingel analysis of total lens extracts (Fig. 3A) and cytoskeletal fractions (not shown), followed by immunoblotting with monoclonal antibodies to desmin (RD301) and vimentin ( $R$ V202), showed that the pVDes protein is expressed in transigenic lenses (Fig. $3 \mathrm{~A}, \mathrm{~B}$ ). Immunoblotting of $2 \mathrm{D}$ gels from total lens extracts (Fig. $3 \mathrm{C}$ ) confirmed the 

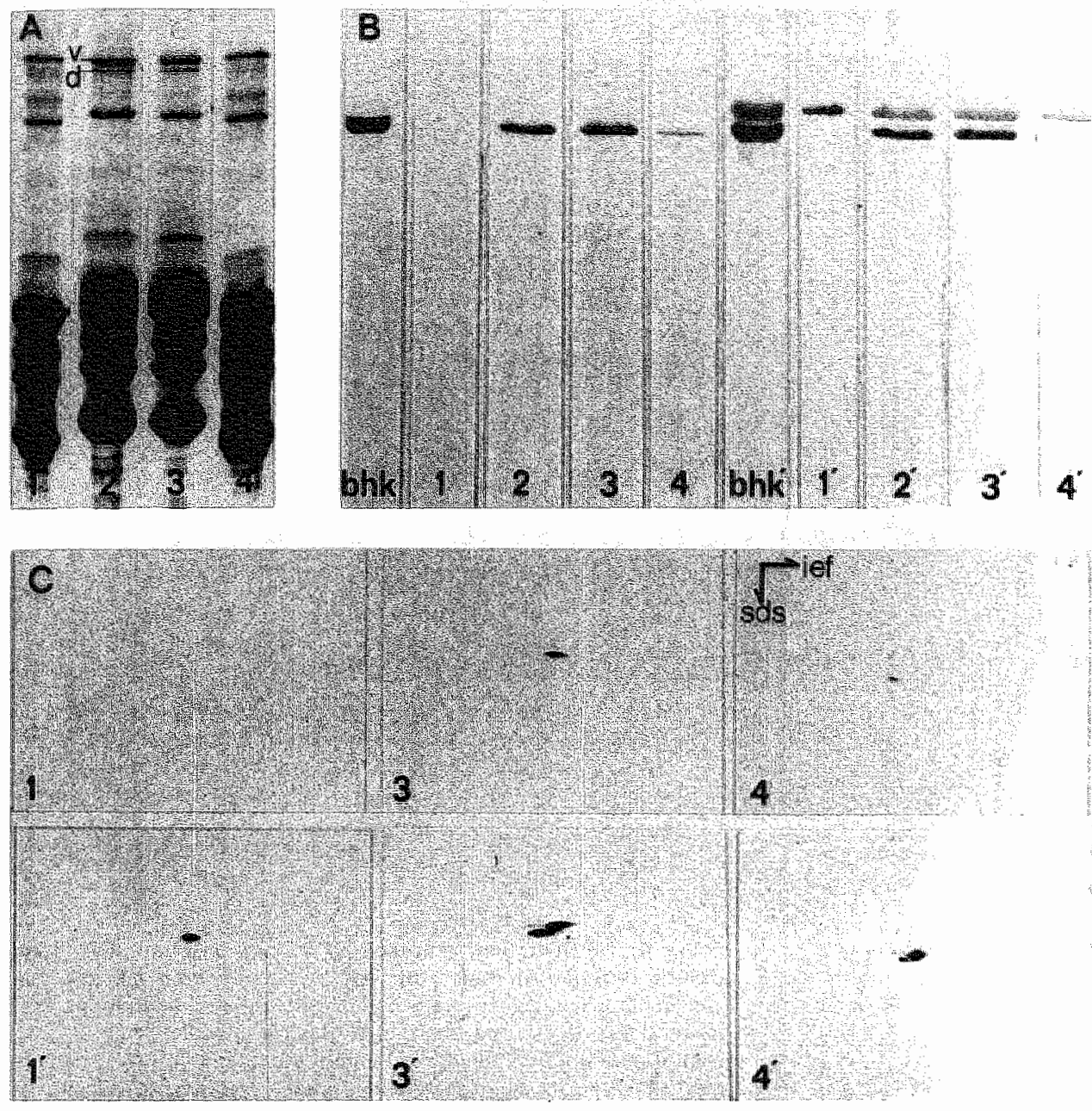

Figure 3: Charactarization of pVDes protein from eye tens. A. Coomassie Brilliant Blue (CBB)-staingd SDS-polyacrylamide gels with abual amounts of total lens extracts from 11 control and transonic mice: 21 strain 426 , 3) strain 429 and 4 ) strain 430 . B) Immunoblots on total lens stracts irom control and transgenic mice incubated with the monoclonal antibody to desmin (RD301; brik, 1.4) and then with

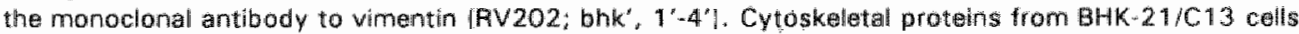
were used as markers. C) Total tens extracts of control $\left(1,1^{\prime \prime}\right)$ and transgenic mice from strains $429(3$, $3^{\prime \prime}$ and 430 (4, 4") analyzed by 2D SDS-gelelectrophoresis and immunoblotting. Elots were incubated with RD $301(1,3,4)$ and then with RV202 $11^{\prime}, 3^{\prime}, 4{ }^{\prime}$.

identity of the pVDes protein, which comigrated with desmin from BHK-21/C 13 hamster cells (not shown). Eye lenses from strains 426 and 429 contain comparable amounts of desmin. A relatively low concentration of hamster desmin was detected in strain 430 lenses. As judged from Cocmassie Brilliant Blue-stained gels and immunoblots of both total lens extracts and cytoskeletal fractions, lens vimentin expression levels were not influenced by pVDes expression. 
To determine the pVDes MRNA expression levels in different tissues and its influence on endogenous vimentin and desmin expression. RMA from transgenic and control tissues was analyzed by Northern blotting. Wo also included RNA from transgenic mice which express the vimentin desmin hybrid gene pVVim 2 1361. In this construct, the last three exons of the wirmentin gene have been replaced by the last three exons of the desmin gene, allowing the detection of the pVVim2 transcript with a desmin-specific probe. Blots were first hybridized to a vimentin-specific probe (E49; Fig. $1 \mathrm{~A}$ ), which recognizes both endogenous vimentin, pVDes and pVVim2 transcripts, and subsequently to a desminspecific probe (X54: Fig. 1A). in control tissues only a $2.0 \mathrm{kbp}$ mRNA band was detected, representing the mouse vimentin messenger (e.g.x Fig. 4A, lane 4). In transgenic tissues an additional $2.4 \mathrm{kbp}$ or $2.3 \mathrm{kbp}$ band was observed that corresponds to the correctly sized pVDes transcript (e.g. Fig. 4A, lanes 1-3), or the pVVim2

A
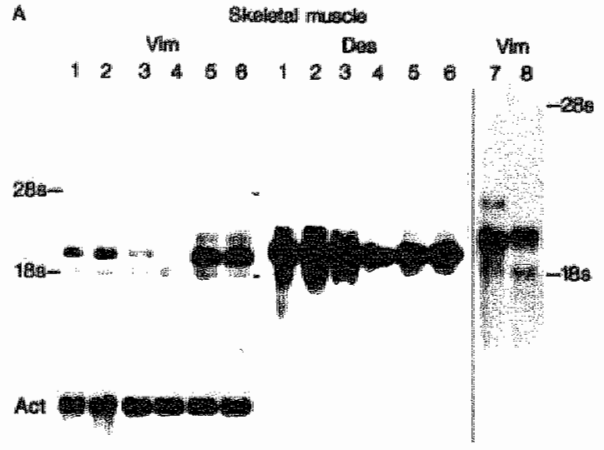

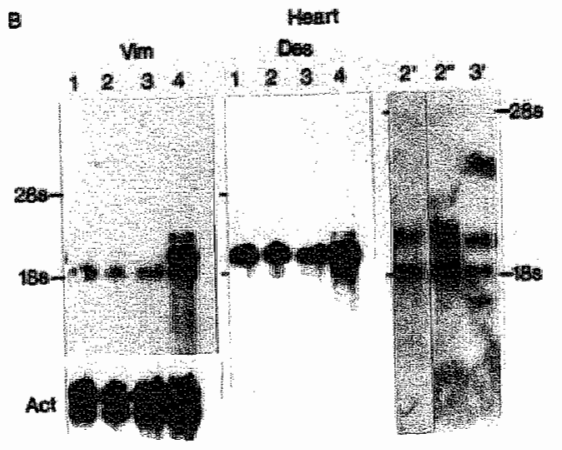

c

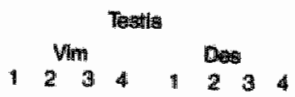

2018-

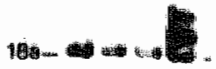

Aot

longer gel and hybpidized to E49 llanes 7,81 . B) RNA from heart tissue. lanes 11 pVDes strain 426 ; lanes 21429 : lanes 31 control; lanes 41 pWWim2 strain 44 . To identify postively pVDes and endogenous desmin mPNA, longer exposure times, low stringency washes, and longer gels were used (lanes $2^{\prime}$ and $3^{\prime \prime}$; lane $2^{\prime \prime}$ as for lane 2, hybridized to E49; lane $2^{\circ}$ ) as for lane 2 , hybridized to E49 and $\times 54$, subsequently, lane 31 as for lane 3 , hybridized to $E 49$ and $\times 54$, subsequentiv; lanes 1-4) exposure time and del length as in figure 4A and $C$. CI RNA from testis. lanes 11 pVDes strain 426; lanes $2 / 429$, llanes 3 l control; lanes 4) pVVinz strain 44. After hybridization to X54 and long exposure thmes, a fain $2.3 \mathrm{kbp}$ band was observed in lanes $1-3$, representing endogenous desmin tnot shown.
Figure 4: Northern blot analyses of $15 \mu \theta$ of total RNA from skeletal muscle $(A)$, heart $(B)$, and testis $(C)$ from control and transgenic mice. Blots were hybridized to a vimentin specific probe (E49; Vim), and then to a desmin-specific probe $(X 54$; Desl. The mimor additional band above the desmin mRNA position was obserwed in all tissues and probably represents a splicing intermediate or is derived from a cryptic initiation site. After dehybridization the blots were hybridized to an actin probe (Act) that recognizes both a actin $(1.8 \mathrm{kbp})$ and $B / y$ actin transcripts $(2.1 \mathrm{kbp})$. Similar analyses were perform-ed on RNA from kidney, liver, spleen, brain and lens (results not shownl. A) RNA from skeletal muscle of abdomen (lanes $1,3,4,5$ ) and thigh llanes 2 , 6). lanes 1, 2 and 81 pvDes strain 426; lanes 3 429; lanes 4 ) control lanes 5w7) p.WWm2 stran 44. To illustrate the difference in length between pVWim2 and pVDes transcipts 12.3 and 2.4 kbp respectively. FNA from strains 44 and 426 was run on a 

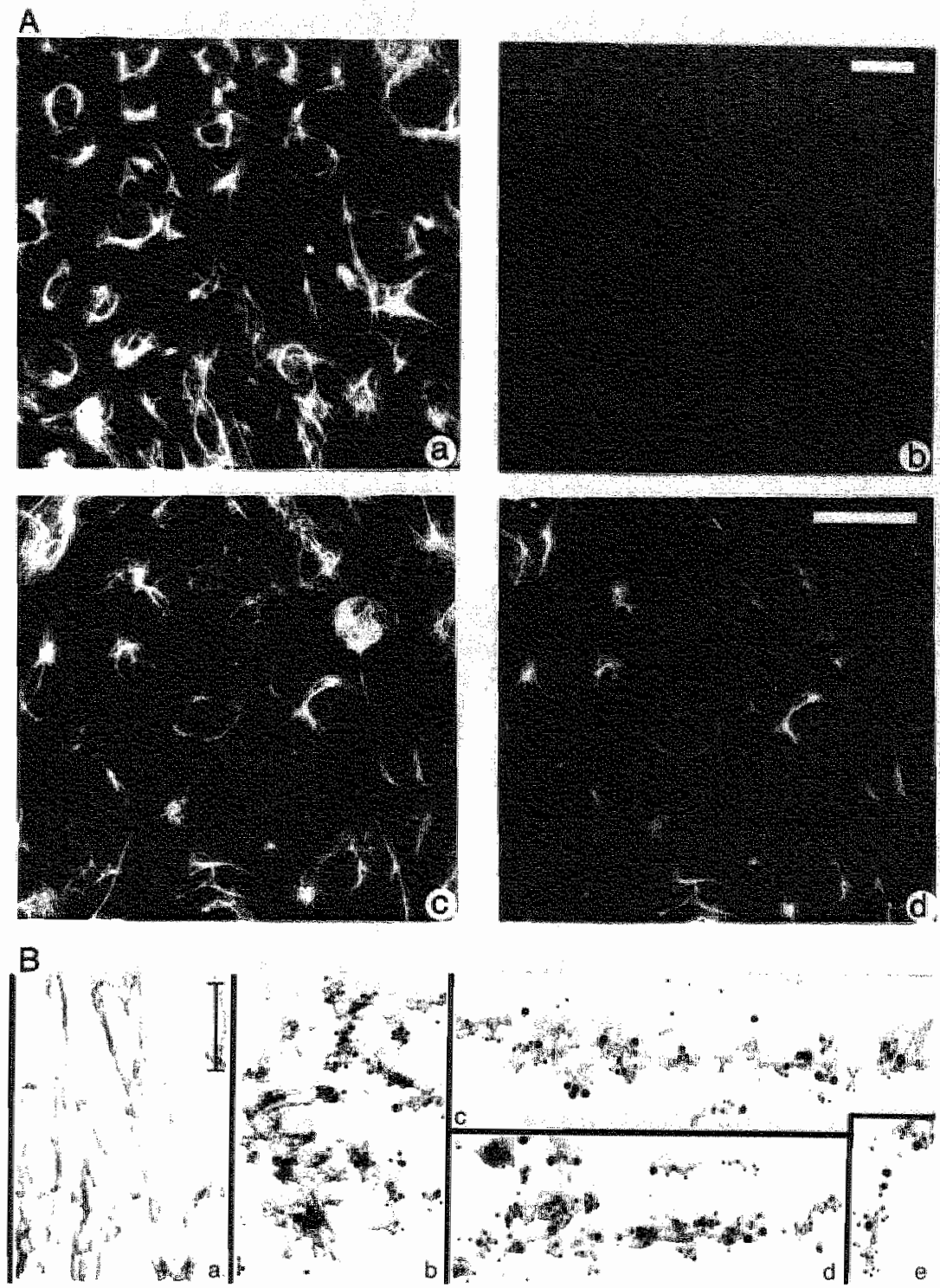

Figure 5: A) Double-label immunotiuorescence staining of control (a and b) and transgenic le and d) transtormed ear-shell fibroblasts incubated with pVim $(a, c)$ and the rronoclonal antibody to desmin RD30 10 , d). Note colocalization of fiaments stained by both antibodies in tansgenic earmall Hibroblasts. Bars indicate $4 \mathrm{~km}$. BI Colocalization of desmin and vimentin in $1 F \mathrm{~s}$ of transgentc cultured ear-stiell fibroblasts as seen at the ultrastructural level after double-immumogold labelling. All preparations were incubated with a mixture of secondany antibody-coated colloidal gold probess in the detection step. a) IFs from transgenic fibroblasts incubated with PQS instead of primary antibodies. b and cl IFs from control fbl and transgenic (c) fibroblasts, incubated with pVim and RD30\%, detected with $50 \mathrm{~nm}$ and $10 \mathrm{~nm}$ gold particies, resp. d and e) IFs from transqenic fibroblasts. incubatad with pDes and PW202, detected with $5 \mathrm{~mm}$ and $10 \mathrm{~mm}$ gold particles, respectively. Bar indicates $200 \mathrm{~nm}$. 


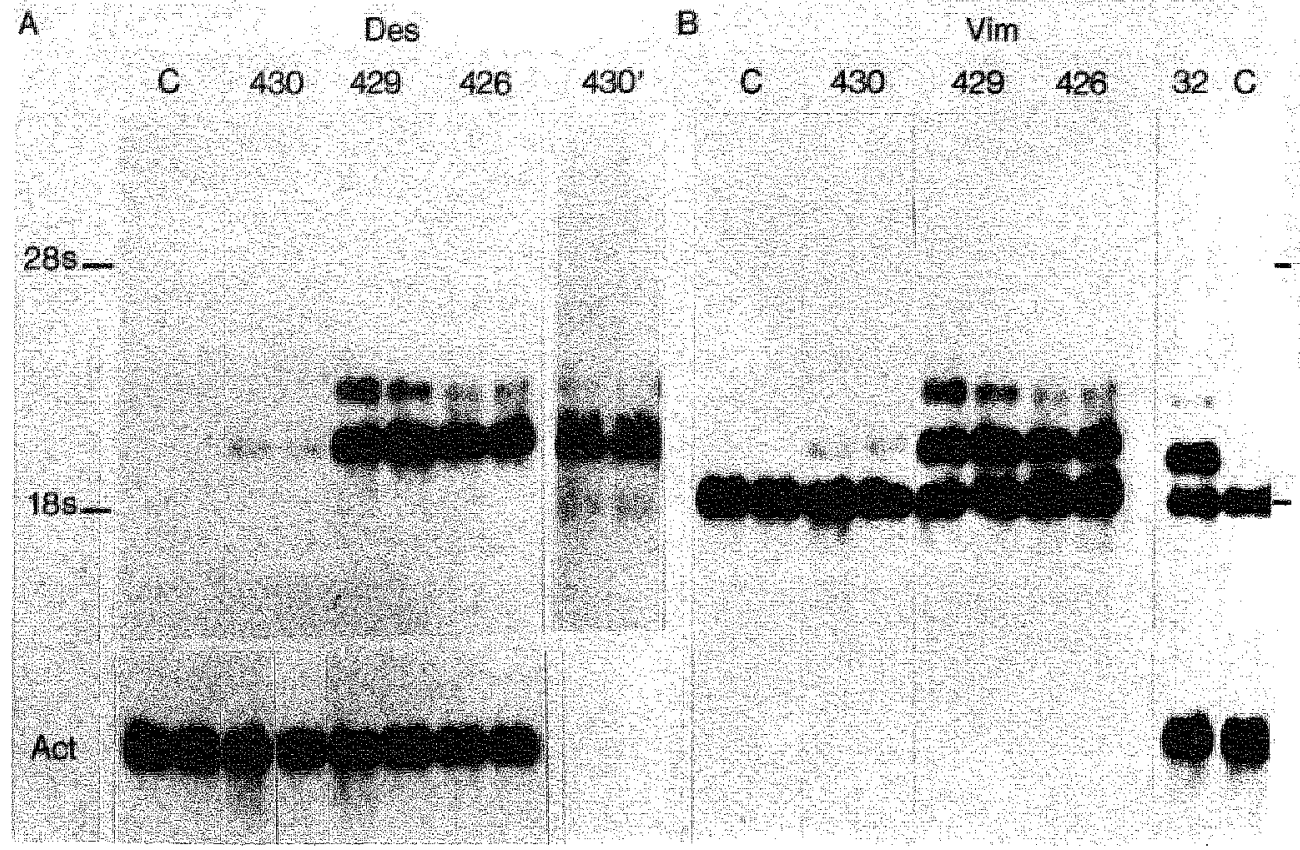

Figure Northern blot analysis of $10 \mu$ of total RNA from exponentially growing control (C) and transqenlic transformed ear shell tibroblast cell lines lpWDes strains 426,429 , and 430 ; pVVim2 strain 321 . To exclude clonal varlation and influences of growth conditions on expression levels, RNA was isolated from two independent cell lines for each pVDes strain. Blots were hybridized to a desmin- (A, X54; Desl and $\$$ ubsequently to wimentin-specific probe $18, E 49$; Viml. After dehybridization the blots were hybridized to an actin-specific probe (Act). Fibroblasts from stain 430 contained relatively little pWDes transcripts, which were readily detected, however, after longer exposure times Ilanes $\left.430^{\prime}\right)$.

transcript, respectively (e.g., Fig. 4A, lanes 5 and 6). Primer extension analysils showed that transcription started at the authentic initiation site (data not shown). Expression levels were determined by densitometric scanning of autoradiographs from blots containing equal amounts of RNA. Actin mRNA levels served as a standard. The levels of vimentin MRNA did not differ between control and transgenic tissues (Fig. 4). Relative to mouse vimentin mRNA, the amount of pVDes transcripts varied between different tissues. Im skeletal muscle tissue, pVDes expression was relatively high, exceeding mouse vimentin transcript levels. (Fig. 4A). Both pVDes and pWVim2 mRNA levels were identical for sketetal muscle tissue from different parts of the body (Fig. 4A, lanes 1, 2, 5, 6). The lowest pVDes expression levels were detected in heart tissue (Fig. 4B). Again, no pVDes expression was observed in testis from different transgenic strains (Fig. 4C) indicating that the lack of expression in Sertoli and Leydig cells is caused at the level of transcription or as result of mPNA instability. In contrast, pVVim2 was expressed at high levels in testis of transgenic mice (Fig. 4C, lane 4). Generally, pVDes expression levels weire higher in tissues from strain 429 than in corresponding tissues from strain 426 (data not shown). An exception is skeletal muscle tissue, which in strain 426 contained almost twice the amount of pVDies mRNA found in strain 429 (Fig. 4 C). The relative levels of pWVim2 expression also varied between different tissues and were highest in skeletal muscle. 
Transgemic cell lines were established by immortalization of ear-ghell fibroblasts from offspring of strains 426,429 and 430 with SV 40 . Double-label immunofluorescence assays showed that in each of these cell lines both desmin and vimentin are expressed and assembled into filamentous structures (Fig. 5A). In assays where the polyclonal wimentin antiserum and the monoclonal antibody to desmin were combined, vimentin and desmin staining intensities were about equal for cell lines 426 and 429 . whereas cells from line 430 showed a much weaker desmin staining intensity. Upon incubation of line 430 fibroblasts with pDes, this difference was not observed. Generally, there was a complete match of desmin and vimentin fllaments (Fig. 5A: c, d). Double-immunogold labelling of control and transgenic fibroblasts revealed that the pVDes protein coassembled into bona fide IFs together with endogenous vimentin (Fig. 5B, a-e).

The pVDes and vimentin expression levels of the transgenic cell lines were analyzed by Northern blot analysis using desmin-and wimentin-specific probes (Fig. 6A, B). The pVDes transcript was of the expected size $(2.4 \mathrm{kbp}$ ) and was detected in all three cell lines (Fig. 6A). For cell line 430, the pVDes mRNA level was 20-fold lower than that of mouse vimentin MANA. In contrast, cell lines 426 and 429 showed pVDes MRNA levels that were similar to those of the endogenous vimentin. The amount of wimentin mRNA 12.0 kbp) was not influenced by pVDes expression (Fig. 6B). This was also observed for a pVVim2 expressing ear-shell fibroblast cell line (strain $32 ;[36]$ ), which was cultured in parallel (Fig. 6B). As in transgenic tissues, pVDes mRNA was less abundant than pVVim2 MRNA.

To identify the pVDes protein in the ear-shell fibroblast cell lines and determine the correlation between transcript and protein levels in vitro, the relative amounts of IF

A

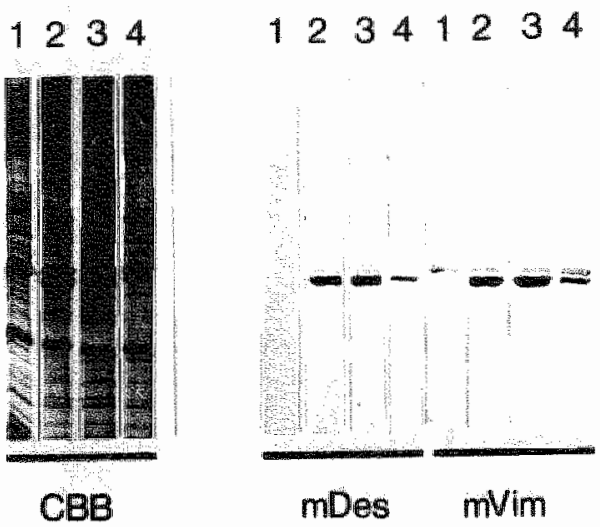

Figure 7: Cytoskeletal fractions of control llanes 11 and transgenic llanes 2-4l transformed car-shelt fibroblast cell ines, analyzed by ID SDS. gelelectrophoresis and inmmunobloting. Al Coomassie Brilhant Blue (CBB) staining of SDSpolyacrylamide gel. B) Immunoblots, inculbated with the monoclonal antibody to desmin IAD301, mDes) and subsequently with the monoclonal antibody to vimentin (RV202, mVim). lane 1) Control fibroblasts: lane 21 strain 426 ; lane 31 strain 429; lame 4 strain 430 . protein in cytoskeletal fractions of the transgenic cell lines were analyzed by $1 D$ SDS.gel electrophoresis (Fig. 7). Desmin and vimentin were identified by immunoblotting with monoclonal antibodies to desmin (RD301) and vimentin (RV202), subsequently (Fig. 7B). The pVDes protein has an apparent molecular mass of $54 \mathrm{kDa}$ and cannot be distinguished from harnster desmin of BHK-21 cells. Coomassie Brilliant Blue-stained gels reflected the levels of IF mRNA (Fig. 6 ) at the protein level (Fig. 7A).

Induction of pVDes expression in tissue culture

In liver tissue, hepatocytes express specific cytokeratins and completely lack vimentin 1161. Culluring of rat hepatocytes induces vimentin expression 1171 . Indirect immunofluorescence assays with pVim, pDes and pKer on frozen sections of liver from control and transgenic mice confirmed that hepatocytes express only cytokeratins, whereas Kuppfer cells express vimentin in control mice and also desmin in transgenic mice. 

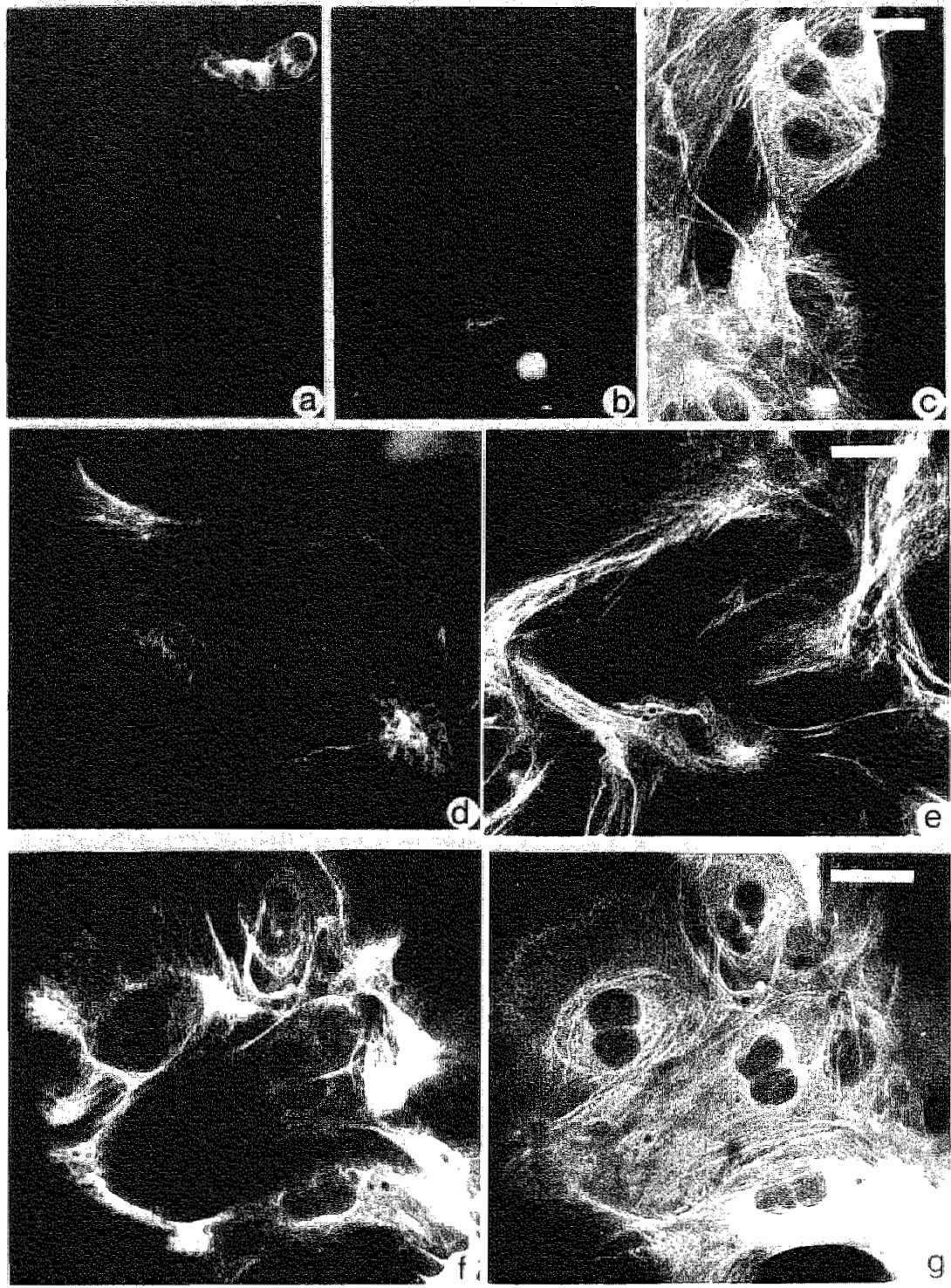

Figura 8: Indirect immunofluorescence microscopy of primary hepatocyte cultures from cantrol mice. Staining was perfomed with monoclonal and polyclonal antibodies to desman, vimentin, and cytokera. tins after different periods of culture. al Hepatocytes cultured for $8 \mathrm{~h}$, pWim stained Note absence of vimentin filaments in theptocytes and strong, filamentous staining of a contaminating fibroblast. $b$ and c) Double-label immunofluorescence staining for vimentin and cytokeratin (pVim and RCK1O2. respectively after $8 \mathrm{~h}$ of culture. Hepatocytes are vimentin negative (b) but contain cytokeratin filaments $(c)$. and Hepatocytes cultured for $18 \mathrm{~h}$ and $40 \mathrm{~h}$, respectively, and pvim stained. Note gradual increase in vimentin expression. $f$ and g) Double-label immunofluorescence staining for vimentin and cytokeratin (pVim and $\mathbb{R C K 1 0 2 , ~ r e s p e c t i v e l y ) ~ a f t e r ~} 40 \mathrm{~h}$ of culture. Hepatocytes contain both vimentin (f) and cytokeratim lilaments $(g)$, which do not seem to colocalize. Bars indicate 4 , mm. 

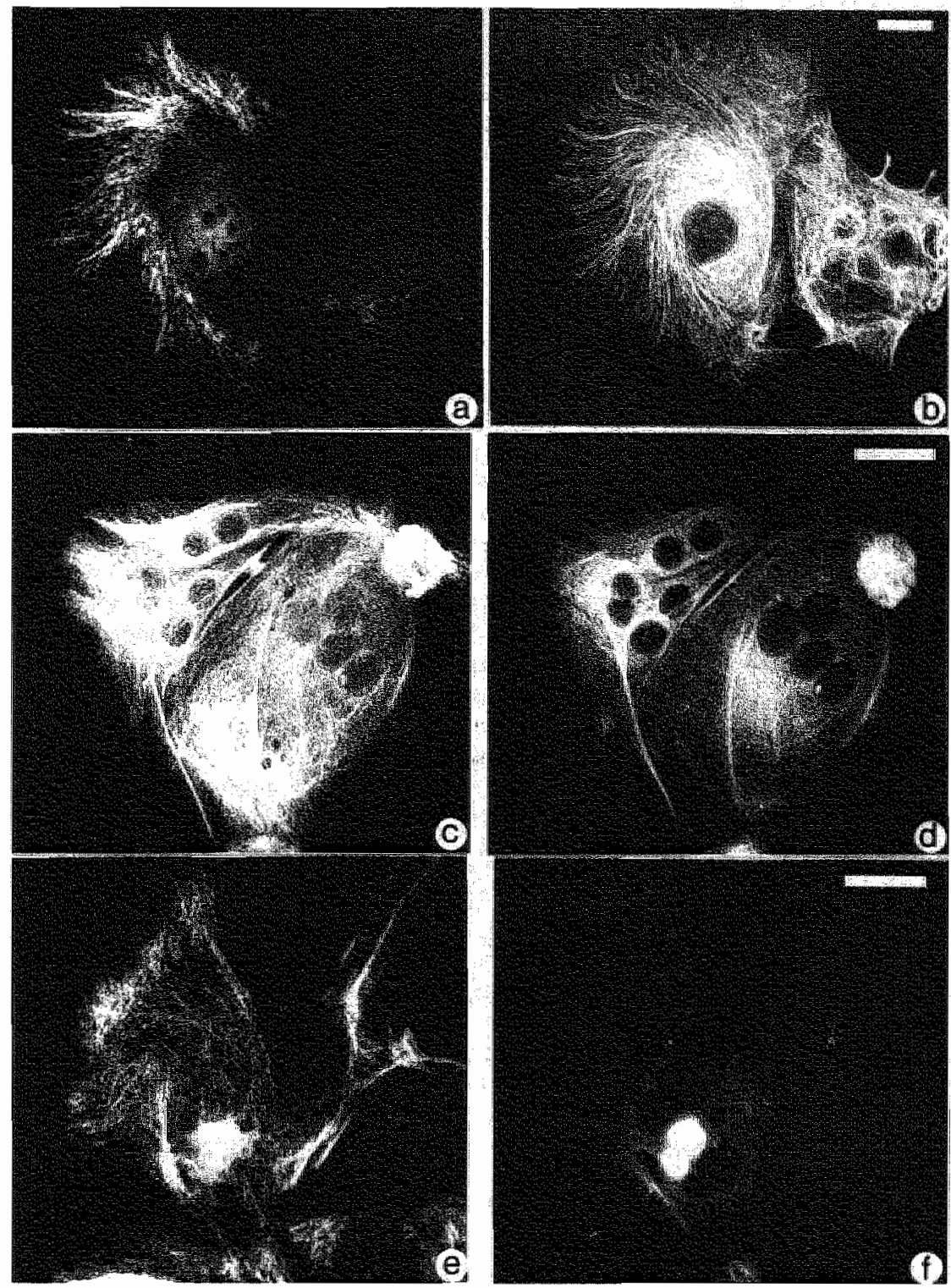

Figure 9: Indirect doubla-label immunofluorescence staining of primary thepatocyte cultures from pVDes transgenic mice, strains 429 (âd) and 426 (e and fl. a and b/ Stauning for desmin (a; pDes) and cycokeratin $(\mathrm{b}$; ACK 102 after $35 \mathrm{~h}$ to $4.0 \mathrm{~h}$ of culture. Note filamentous desmin staining of one hepatocyte with pDes while an adjacent hepatocyte is completely desmin negative lal. Both cells express cytokeratins in large amounts $|b| c$ and di Staining for vimentin lc; pVimi and desmin ld: RD309.. Note expression of both vimentin (c) and desmin (d). and fi Staining for vimentin le; pVimil and desmin [f: RD301] of strain 426 hepatocytes after $70 \mathrm{~h}$ of culture. Note complete absence of desmin staining (1), whille vimentin is expressed abundanty (e). Bars indicate $4 \mu \mathrm{m}$. 
Hepatocytes from control and transgenic mice (strains 426 and 429 ) were isolated. cultured as monolayer, and analyzed for If expression by the indirect immunofluorescence assay during 4 days of culture. In all cases, the onset of vimentin synthesis was observed after $12-14 \mathrm{~h}$ (Fig. 8). At this point, vimentin expression occurred in only few cells and staining intensities were low. In addition, the filaments were not distributed uniformly throughout the cell but were located at the periphery (Fig. 81. Within the next $30-40 h$, the number of vimentin containing cells and the amount of vimentin in each cell increased until almost every cell was vimentin positive. Cytokeratins were expressed continuously and did not colocalize with vimentin filaments (Fig. $8 \mathrm{f}, \mathrm{g}$ ). About $25 \mathrm{~h}$ after the earliest detection of vimentin in the immunofluorescence assays, hepatocytes from transgenic mice of strain 429 initiated expression of desmin (Fig. 9a, b). Again, a gradual increase in expression over a 40 -hour period was observed until most cells were desmin positive. In control hepatocytes, desmin expression was never observed. Eventually, desmin and vimentin staining patterns were identical, suggesting copolymerization of these proteins. In cultured hepatocytes from four different transgenic mice of strain 426 . desmin expression could not be detected (Fig. 9e, f). Each of these mice, however. showed the tissue-specific expression pattern that is characteristic of all pVDes transgenic mice and, as described, puDes levels in strain 426 were generally comparable to those of strain 429 , both in tissues and in the fibroblast cell limes. To extend our analysis, hepatocytes of the two different pWVim 2 transgenic mouse strains (Nas. 32 and 44: 1361) were also brought into culture. Hepatocytes from these mice displayed wimentin and cytokeratin expression patterns, which did not differ from those of control and pVDes hepatocytes. Initiation of pVVim2 ex-pression was observed 1 day later than vimentin expression.

In summary, tissue culture-induced IF gene construct expression occurred in three out of four transgenic strains.

\section{DISCUSSION}

Expression of desmin in adult mammalian tissues occurs almost exclusively in muscle cells. We have changed the tissue-specific distribution of this IF protein by creating transgenic mice, which express the IF gene construct pVDes, composed of the coding region of the hamster desmin gene and the $5^{\prime}$ flanking region of the vimentin gene, in a vimentin-specific fashion. The pVDes protein was indistinguishable from hamster desmin. The levels of $p v D e s$ protein recovered in cytoskeletal fractions from transigenic cell lines correlated with the pVDes mRNA levels, supporting the notion that If synthesis is determined primarily by the amount of mRNA present $[43,46,54,58]$. Double-label immunafluorescence assays and double-immunogold labelling of cultured transgenic ear"shell fibroblasts showed that the pVDes protein assembled into IFs that colocalized with the endogenous vimentin filaments. This is in agreement with previous reports concerning coexpression of desmin and vimentin in different types of muscle celis $(49,62)$. Taken together, the data indicate that the pVDes-encoded desmin subunits are incorporated into the endogenous vimentin filaments.

The in vivo expression pattern of the pvDes protein was determined by immunohistochemical analysis of tissue sections from different transgenic strains. Each transgenic mouse and all offspring expressed hamster desmin in a vimentin-specific fashion. pVDes expression did not detectably affect cellular morphology or differentiation. Desmin synthesis in vimentin-negative cells was never observed. Surprisingly, no pvDes expression was detected in Sertoli and Leydig cells of all three lines of transgenic mice although these cells do express vimentin $[12,66,67\}$ (Fig. 2). This lack of expression is either caused at the transcriptional level or by pVDes mRNA instability since no pVDes 
transcripts were detected in transgenic testis $1 F i g .4 \mathrm{Cl}$. In contrast, an if gene constuduct (pVVim2), consisting of the 5" flanking region and first six exons plus introns of the vimentin gene, fused to the last three exons and introns of the desmin gene is expressed in these testicular cells. Since regulatory elements have been identified within introns of some genes $[2,26,35,45,55,60]$, it is possible that such elements are located within the first six introns of the vimentin gene.

An important aspect of gene regulation in general is the establishment of the appropriate level of expression. For vimentin, questions concerning the mechanisms of this aspect of regulation cannot be addressed by the use of cultured cells only, since it is unclear whether or not expression levels are elevated upon culturing of vimentin-expressing cells. overruling regulatory mechanisms active in vivo. We show here that endogenous vimentin mRNA and protein levels were not influenced by pVDes expression. Obviously. the amounts of IF protein are not strictly regulated and can be elevated without deleterious effects.

The highest pVDes transcript levels were detected in skeletal muscle tissue (Fig. 4). Immunohistochemical staining of striated muscle tissue sections showed that nonmuscle cells, which are included in this tissue, express both vimentin and pVDes (Fig. 2). Transgenic myoblasts presumably also express these proteins. Since the pVDes encoded hamster desmin is indistinguishable from endogenous mouse desmin in these stainings, we cannot exclude the possibility that pVDes is also expressed in muscle cells of transgenic mice; e.g., as a result of the presence of muscle-specific regulatory sequences within the introns of the desmin gene in addition to thase present in the desmin gene $5^{\prime}$ region [46]. However, pVVim 2 mRNA levels were also highest in skeletal muscle tissue (Fig. 4), but it has been shown that the pVVim2 protein is not expressed in transgenic striated muscle cells [36]. Furthermore, in transgenic heart tissue pVDes mRNA levelis were low although endogenaus desmin is expressed at high levels (Fig. 4B).

Our studies on cultured hepatocytes establish that sequences in the $3.2 \mathrm{kbp}$ of $5^{\prime}$ flanking region of the wimentin gene confer tissue culture-induced vimentin expression. In hepatocytes from pVDes strain 429 , desmin protein expression was first observed after 40 to $50 \mathrm{~h}$ of culture, and lagged $-25 \mathrm{~h}$ behind the initiation of vimentin synthesis. A similar time lag was observed in hepatocytes from pVVim2-expressing mice. pVDes and pVVim2 transcripts also were detected -1 day later than vimentim mRNA ldata not shown). This lapse may result from differences in mRNA stabilities. On the other hand, species differences in cis regulatory sequences of the hamster and mouse vimentin genes could explain the observed delay in desmin synthesis. Reports on vimentin expression during avian and mammalian hematopoiesis have shown that divergence of cis-linked sequences can result in species-specific regulation of expression [43]. Timing of human neurofilament (NF-L) gene expression in transgenic mice also differed from endogenous NF-L expression [31].

Cultured hepatocytes from pvDes strain 426 expressed vimentin, but no pVDes expression could be detected by indirect immunofluorescence (Fig. 9) and Northern blotting (data not shown). However, mice from this strain displayed tissue-specific pVDes expression at similar levels as strain 429. The site of integration of the pVDes copies in strain 426 might not allow transcriptional activation under in vitro conditions. At the same time, regulatory processes in control of tissue-specific and tissue culture-induced vimentin expression may not be identical. We did not detect major rearrangements in the vimentin promoter region of the pVDes copies of strain 426 . It remains to be established

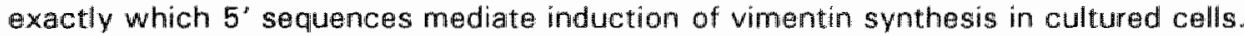

The reasons for the existence of the highly-specific expression patterns of desmin and vimentin are unknown. Although the functional differences between these proteins are obscure, some different properties have been noted. Comparison of hamster vimentin and desmin in vivo phosphorylation patterns have shown that desmin contains an additional, subunit-specific phosphorylation site in the $\mathrm{COOH}$-terminal "tail" region 110,201 . This might allow a differential response to exogenous stimuli and may reflect subunit-specific 
Hunctions. In addition, it has been described that the "tail" domains of desmin and wimentin both associate with lamin $B$ at the nuclear envelope but with different affinities. [251. In double-labiel immunofluorescence assays on transgenic ear-shell fibroblast cells and cultured hepatocytes we observed a small percentage of cells that displayed large differences in desmin and vimentin staining intensities, suggesting that some filaments contained predominantly desmin or vimentin subunits. The same observation has been made for pVVim2-expressing cuitured fibroblasts [36]. This might reflect differences in assembly characteristics.

The coexpression of desmin and vimentin in tissues and cultured cells from transgenic mice did not result in detectable abnormalities. Future experiments, aimed at interfering with IF expression in wha will hopefully shed some light on the function of these cytoskeletal structures.

Acknowledgements: We thank Dr. Theo Cuypers for helpful discussions and ideas Wilma Vree Egberts, Olof Moesker and Hennie Roefs are acknowfedged for excellent technical assistance. We also thank Dr. S.H. Yap for making available to us the laboratory facilities at the division of gastrointestinal and liver diseases.

\section{REFERENCES}

1. Aufrey $C_{\text {. }}$ Rougeon F. Purification of mouse immunoglobulin heawy chain mRNAs from total miveloma tumor $\mathbb{R N A}$. Eur. J. Blochem. 107, 303.314, 1980.

2. Banerij J, Olson L, Schafner W. A lymphocyte-specific cellular enhencer is located downstream of the foining region in immumoglobulin heavy chain genes, Cell 33,729-740, 1983.

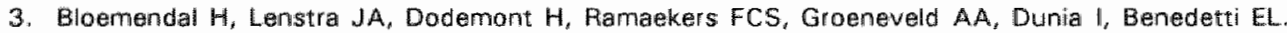
SV40-transformed hamster epithellal cells: a novel system for the isolation of cytoskeletal messenger RNAs and their translation products. Exp. Exe Res. 31, 513-525, 1980 .

4. Broers JLV, Carney DN, Klein Rot M, Schaert $G$, Lane EB, Vooijs GP, Ramaekers FCS. Intermediate filament proteins un classic and variant types of small cell lung carcinoma cell hines: a biochemical and immunological analysis using a panel of monoclonal and polyclonal antibodies. J. Cell Sci. 83, 37-60, 1986 .

5. Church GM, Gilbert W. Genomic sequencing. Proc. Natl. Acad. Sci. USA 81, 1991-1995, 1984,

6. Connell ND, Rheinwalid JG. Regulation of the cytoskeleton in mesothellal cells: reversible lass: of keratin and increase in wimentin during rapid growth in culture. Crell $34,245-253,1983$.

7. De Mey J. The preparation and use of gold probes. In: Immunocytochemistry: Modern Methods and Applicarions. 2nd edition leds. Polak JM and Van Noorden Jl John Wright and Sans LTD., Bristol, pp. 115-145, 1986.

8. Dodemont $H J$, Soriand $\mathbb{P}$, Quax Ws, Ramaekers $F$, Lenstra JA, Groenen MA, Bernardi G, Blowmendal $H$. The gents coding for the cytoskeletal proteins actin and wimentin in warmublooded vertebrates. EMBO J. 1, 167-171, 1982.

9. Drager UC. Coexistence of neurofilaments and wimentin in a neurone of adult mouse retina. Nature $303,169-172,1983$.

10. Evans RM. The intermediatefilament proteins vimentin and desmin are phosphorylatted in specific domains. Eur. J. Cell Biol. 46, $152-160,1988$.

11. Ferrari $S$, Battini $R$, Kaczmarek L, Fittling $S$, Calabretta B, Riel J Kim de, Philiponis V, Wei JF, Baserga R. Coding sequence and growth regulation of the human vimentin gene. Mol. Cell. Biol. B. $36143620,1986$.

112. Franke WW. Nuclear larmins and cytoplasmic intemediate fillament proteans: a growing multigene family. Cell $48,3 \times 4,1987$.

13. Franke WW, Moll A. Cytoskeletal components of Iymphoid organsi. 1. Synthesis of cytokeratins 8 and 18 and desmin in subpopulations of extrafollicular reticulum cells of human lymph nodes, tonsils and spleen. Differentiation $36,145-163,1987$.

14. Franke WW, Grund $C_{\text {. Schmid }}$. Intermediate-sized filaments present in Sertoli cells are of the vimentin-type. Eur. J. Cell Biol. 19, 269-275, 1979.

15. Franke WW, Schmid $E_{\text {. Winter }} \mathrm{S}$, Osborn M, Weber K. Widespread occurence of intermediatesized filaments of the vimentin-type in cultured cells from diverse vertebrates. Exp. Cell Res. 123, $25-46,1979$. 
16. Franke WW, Denk $H_{*}$ Katt $\mathbb{F}_{*}$ Schmid E. Biochemical and inmunblogical identibation of cytokeratin proteins present in hepatocytes of mammalian iwer tissue. Exp. Cell Res. $131,299$. 318. 1981.

17. Franke WW, Mawer D, Schmid E. Denk $H$, Borenfreund E. Differences of axpression of cytoskaletal proteins in cultured rat hepatocytes and hepatoma cells. Exp. Cell Fes. 134, 345-365, 1981.

18. Franke WW, Grund $C_{\text {, }}$ Kunn $C$. Jacksom BW, limensee K. Formation of cytosketetal elements during mouse embryogenesis. Ill. Primary mesenchymal cells and the first appeanance of vinentin Iilaments. Differentiation $23,43 \times 59,1982$.

19. Franke WW, Hergt M, Giund $C$. Rearrangement of the vimentin cytoskeleton during adipose conversion: formation of an intermediate filament cage around lipid globules. Cell 49. 131-141. 1987.

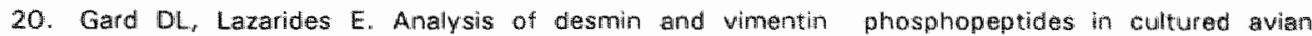
myogenic cells and their modulation by 8-bromo-adenosine $3^{\prime}, 5^{\prime \prime}$-cyclic monophosphate. Proc... Natl. Acad. Sci. USA 79,6912-6916, 1982.

21. Gawlitta W, Osborn M, Weber $K$. Coilling of internediate fillaments induced by microinjection of a specific monoctonal antibody. Cell $24,185-193,1981$.

22. Geisler $N$, Weber $K$. The amino acid sequence of chicken muscle desmin provides a common structural model for intermediate filament proteins. EMBO J. 1, 1649-1656, 1982.

23. Geisler $N$, Weber $K$. Structural aspects of intermediate filaments. In: Cell and Molecwlar Blology of the Cytoskeleton. (ed. Shay Gl Plenum, New York, pp 41-64, 1986.

24. Gellebter J.Zef RA. Melvold RW, Nathenson SG. Mitotic recombination in perm cells generated two major histocompatibility complex mutant genes shown to be identical by RNA secuence analysis: $K^{\tan 9}$ and $K^{\text {tans }}$. Proc. Nati. Acad. Sci. USA 83, 3371-3375, 1986.

25. Georgatos SD, Weber K, Geister $N$, Blobel G. Binding of two desmim derivatives to the plasma membrane and the nuclear envelope of avian erythrocytes: evidence for a conserved sitespecificity in intermediate fillament-membrane interactions. Proc. Natl. Acad. Sci. USA. 84, 6780$6784,1987$.

26. Gillies $\mathrm{SD}$, Morrison $\mathrm{SL}$, Oi VT, Tonewaga. A tissue spectfic transcription emhancer ellement is located in the major intron of a rearramged immunoglobulin heawy chain gene. Cell $33,717-728$, 1983.

27. Hedberg $K K$, Chen LB. Absence of intermediate filaments in a human adrenal cortex carcinomaderiwed cell line. Exp. Cell Res, 163, 5091517, 1986.

28. Heuwel RMM wan den, Eys GJJM van, Ramaekers FCS, Quax W.J, Vree Egberts WTM, Schaart G. Cuypers HTM, Bloemendal H. Intermediate fillament formation after transfection with modified hamster vimentin and desmin venes. J. Cell Sci, 88, 475-482, 1987.

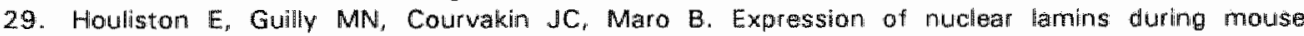
preimplantation development. Development 102, 271.278, 1988 .

30. Jackson BW, Grund C, Winter S. Franke WW, Ilmensee K. Formation of cytoskeletal elements during mouse embryogenesis. II. Epithellal differentiation and intermediate sized filaments in early postimplantation embryos. Differentiation 20, 203-216, 1981 .

31. Julien JP, Tretiakoff T, Beaudet L, Peterson E. Expression and assembly of a human neurofilament protein in transpenic mice provide a novel newronal marking system. Genes and Devalopment 1 , 1085-1095, 1987.

32. Klaunig JE, Goldblatt PJ, Hinton DE, Lipsky MM, Chacko J, Trump BF. Mouse liver cell culture. I. Hepatocyte isolation. In Vitro $17,913-925,1981$.

33. Klatunig JE, Goldblatt PJ, Hinton DE, Ligsky MM, Trump BF. Mouse liver cell culture. Ul. Primery culture. In Vitro 17,926.934, 1981 .

34. Klymkowsky MW, Miller AHA, Lane EB. Morphology, behawiour and interaction of cultuted epithelial cells after the antbody-induced distuption of keratin flament organization. J. Ciell Bioll. 96, 494. $509,1983$.

35. Konieczny SF, Emersin CP. Complex regulation of the musche-specific contractile protain Itroponin Hene. Mol. Cell. Biol. 7, 3065-3075, 1987.

36. Krimpenfort PJ. Schaart. G, Pieper FA, Pamalkers FCS, Cuypers HT, Heuvel AM wan den, Vrea Egberts WT, Eys GJ wan, Berns A, Bloemendal $H$. Tissue-specific expression of a vimentin-desmin hybrid gene in transgenic mice. EMBO $4.7,941-947,1988$.

37. Lame EB, Hogan BLM, Kurkinen M. Garrels Jl. Coexpression of vimentin and cytokerating in parietal endoderm cells of early mouse embryo. Nature 303,701-704, 1983.

38. Lees JF, Schneidemann PS, Skuntz SF, Carden MJ, Lazzarimi RA. The structure and organzation of the human heavy meurofilament subunit INF-HI and the gene encoding it. EMBO $J .7,1947$. 1955,1988 .

39. Leonard DGB, Gorham dD, Cote P, Greene LA, Ziff EB. A nerwe growth factor-tegulated messenger 
RHA encodes a new intermediate Hilament protein. J. Cell biol. $106,181-193,1988$.

40. Lewis SA, dalcarek JW, Krek W, Shetangk M, Cowan Bj. Sequence of a cDNA clone encoding mouse glial fibrilfery acidic protein: structural conserwation of intermediate falaments. Proc. Natl. Acad. Sei. USA 81, 2743-2746, 1984

41. Lillenbaum AV, Leganeux $V$, Portier MW, Dellagi $K$, Paulin D. Vimentin gene: expression in human Mrnphocytes and in Burkitt's lymphoma cells. EMEO J, 5, 2809-2814, 1986.

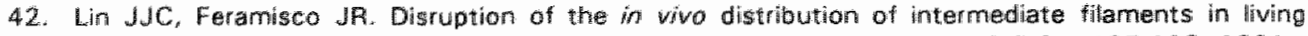
fibroblests through the micinainection of specific monoclonal antibody. Cell 24, 185*193, 1981 .

43. Ngai $\mathrm{J}$, Bond $\mathrm{G}$, Wold $\mathrm{BJ}$, Lazarides E. Expression of transfected wimemtin genes in differentiating murine erythroleukemila cells reveals divergent cis-acting regulation of avian and mammalian vimentin sequences. Mol. Cell. Biol. $7,3955.3970,1987$.

44. Palniter RD, Brinster RL. Germ-line transfornation of mice. Annu. Rev. Genet, 20, 465-499. 1986.

45. Picard D. Schaffner W. A lymphocyte-specific enhamcer in the mouse immunoglobulin gene. Nature 307, 80-82, 1983 .

46. Pieper FR, Slobba RL, Ramakers FCS, Cuypers HT, Bloemendal H. Upstream regions of the harnster desmin and wimentin genes regulate expression during in witro myogenesis. EMBO J.6. $361103618,1987$.

47. Quax W, Vree Eqberts W, Hendriks W, Quax Jeuken Y, Bloemendal H. The structure of the virmenin gene. Cell $35,215-223,1983$.

48. Quax W, Broek L wan den, Vree Egberts W, Ramaekers F, Bloemendal H. Characterization of the hamster desmin gene: expression and formation of desmin filaments in non-muscle cells after gene transter. Cell $43,327-338,1985$.

49. Quinlan RA, Franke WW. Heteropolymer filaments of wimentin and desmin in vascular smooth muscle tissue and cultured baby hamster kidney cels demonstrated by chemical cross-linking. Proc. Natl. Acad. Sci. USA 79, 3452-3456, 1982

50. Ramaekers: FCS, Osborn M, Schmid E, Weber K, Bloemendal H. Identification of the cytoskeletal proteins in lens-torming cells, a special epithelioid cell type. Exp. Cell Res. 127, 309-327, 1980.

51. Ramaekersi FCS, Puts JJG, Moesker O, Kant A, Huijsmans A, Haag D, Jap PHK, Herman C, Voolis GP. Antibodies to intermediate filament proteins in the immunohistochemical identification of human tumours: an owarview. Histochem. J. 15, 691-713, 1983.

52. Ramaekers FCS, Verhelijen FHM, Moesker O, Kant A, Vooils GP, Herman C. Mllesodermal mixed tumor: diagnosis by analysis of intermediate filament proteins. Am. J. Surg. Pathol. 7, 381-385. 1983.

53. Ramaekers FCS, Huljsmans A, Schaart G, Moesker O, Vooils GP. Tissue distribution of keratin 7 as monitored by a monoclonal antibody. Exp. Cell Res. 170, 235-249, 1987.

54. Rittling SR, Baserga R. Functionall analysis and growth factor regulation of the human wimentin promoter. Mol. Cell. Biol. 7, 3908-3915, 1987.

55. Rossi P. Crombrugghe B. Identification of al cell-specific tramscriptional enhancer in the first intron of mouse- $a_{2}$ (type Il collagen gene. Proc. Natl. Acad. Sci, USA 84, 5590-5594, 1987.

56. Schmid E, Osborn M, Rungger-Braendle E, Gabbiani G. Weber $K$, Franke Wh. Distribution of vimentin and desmin thaments in smooth muscle tissue of mammalian and avian aorta. Exp. Cell Aes, $137,329-340,1982$.

57. Schnitzer J. Franke WW. Schachner M. Immunocytochemical demonstration of vimentin in astrocytes and ependymal cells of developing and adult mouse nervous system. J. Cell Biol. 90. $435-447,1981$.

58. Sthinert PM. Roop DR. Molecular and cellular biology of intermediate filaments. Annit. Rew. Biocham. 57, 593-625, 1988.

59. Steinert PM, Stevert AC, Roop DR. The: molecular biology of intermediate filaments. Cell 42. 411 . $419,1985$.

60. Sternberg EA, Spizz G, Perry WM, Vizard D, Weil T, Olson EN, Identilication of upstream and intragenic regulatory elements that confer cell-type-restricted and differentiation-specific expression on the muscle creatine kinase gene. Mol. Cell. Biol. 8, 2896-2909, 1988.

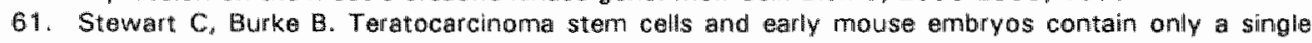
malor lamin polypeptide closely related to lamin B. Cell $51,383-392,1987$.

62. Tokuyasu KT, Maher PA, Singer SJ. Distributions of vimentin and desmin in developing chick myotubes in vivo. 11. Immunoelectron microscopic study. J. Cell Biol. 100, 1157-1166, 1985.

63. Tolle $\mathrm{HG}$, Weber $K_{i}$ Osborn $\mathrm{M}$. Microinjection of monoclonal antibodies to vimentin, desmin and GFA in cells which contain more than one IF type. Exp. Cell Res. 162, 462 474, 1986.

64. Traub P. Intermedrate Filaments. A Rewiew. Springer-Verlag Berlin. 1985

65. Viebahn $\mathrm{C}$, Lane EB, Ramaekers FCS. The mesonephric (Wolffiani) and paramesonephric 
Mulilieran ducts of golden hamsters express different intermediate fiament protelns during embryogenesis. Differentiation 34, 175-188, 1987.

66. Virtanen $I_{1}$ Badlew RA, Paasivuo $R$, Lehto VP. Distinct cytosketeral domains revealed in sperm cells. J. Cell Biol. 99, 1083-1091, 1984.

67. Vorstenbosch $\mathrm{CJ}$, Colenbrander $B$, Wensing CJ, Ramaekers FCS, Vooils GP. Cytoplasmic filaments in fetal and neonatal pig testis. Eur. J. Cell Biol. 34, 292-299, 1984. 



\title{
CHAPTER 7
}

\section{DISRUPTION OF INTERMEDIATE FILAMENTS BY EXPRESSION OF DOMINANT NEGATIVE DESMIN MUTANTS IN TRANSGENIC MICE}

\author{
G. SCHAART
}

Summary of two manuscripts in preparation:

- Pieper FR, Schaart G, Raats JMH, Henderik JB, Ramaekers FCS, Berns A, Bloemendal $H$. Disruption of vimentin intermediate filaments in transgenic mice by expression of a dominant negative mutant desmin subunit.

Raats JMH, Schaart G, Pieper FR, Van de Kemp A, Berns A, Henderik JB, Ramaekers FCS, Bloemendal H. Muscle-specific expression of a truncated desmin subunit in transgenic mice. 
To investigate the functions of desmin and vimentin intermediate filaments in the context of intact tissues and the developing organism, a construct encoding a truncated desmin subunit driven by the desmin or vimentin promoter (pDDV and pVDV, respectively), was introduced into the murine germ line. The mutant desmin was assembly-incompetent and capable of disupting preexisting desmin and vimentin filaments in a dominant negative fashion, both in transgenic mouse tissues. In mouse tissues, high level expression of pDDV and pVDV occurred in a small percentage of desmin- or vimentin-containing cells. respectively, and also in skeletal muscle cells. Immunohistochemical staining of muscle tissue showed a diffuse desmin pattern instead of the dots and clumps into which mutant desmin typically accumulates in other cell types. The over-expression of pDDV and pVDV and the concomitant disruption of both the endogenous desmin and vimentin filaments in a significant percentage of cells as observed for PVDV did not cause any detectable developmental, morphological or functional abnormalities.

\section{INTRODUCTION}

The cytoskeleton of eukaryotic cells is a dynamic structure composed of microtubules, microfilaments, and intermediate filaments (IF). Single IFs are $10 \mathrm{~nm}$ in diameter, and have a length of approximately $40 \mu \mathrm{m}$. IFs can comprise up to $85 \%$ of total cellular protein $[6,13,19,26,27,43,44 \rrbracket$.

IF proteins are encoded by a large multigene family ( $>35$ genes) and can be divided into six different types on the basis of gene structure and sequence homology $16,19,26,27$. 441. To a large extent, these different types of IF subunits are expressed in a developmentally regulated and tissue-specific fashion. This highly conserved specificity of expression would suggest that each type or combination of subunits plays a unique role in cellular differentiation $[6,13,19,26,27,43,44]$. Although all If proteins have a highly conserved secondary structure, their physicochemical properties can be quite different.

While the function of microtubules and microfilaments in cellular processes is well understood, the function of IF proteins has long remained elusive. Cytoplasmic IF proteins clearly do not fullfil a household function, since several cell lines do not contain any cytoplasmic. IF network. In addition, disruption of IF networks in cultured cells does not affect the cell morphology, motility or division [review: 19]. This has led to the assumption that the function of IF proteins must be manifested at the level of the tissue or organ as a whole, possibly in providing mechamical strength, cellular organization and architecture $[15,26,30]$. In agreement with this notion, vimentim If proteins display unique viscoelastic properties allowing them to resist breakage and become even stronger under stress that would rupture other cytoskeletal networks [17].

To address the issue of IF function at this level, different approaches can be chosen. These include actopic expression or aver-expression of If proteins in transgenic mice [1, $7,8,11,18,20,25,291$, specific interference with in vivo IF assembly by microinjection of IF-specific antibodies [19] of anti-sense RNA into zygotes or developing embryos [47]. Also disruption of IF networks in transgenic mice or embryonic cells by expression of dominant-negative mutant IF subunits $[8,9,15,48,51]$, and inactivation of IF genes via homologous recombination in embryo stem cells IBaribault $1991 \rrbracket$ has been applied to investigate IF function.

In cultured cells ir has been demonstrated that IF networks can be disrupted in a dominant-negative fashion by expression of IF gene constructs containing modifications or deletions in the carboxy-terminal part of the central a-helical 'rod'-domain $[2,9,16$, $22,25,34,35,36,42,51,53$ ]. Interaction of the mutant-and wildtype IF subunits results in disassembly of preexisting IF networks and inhibits de novo If formation. 
Expression of keratin gene mutants in skin of transgenic mice caused disruption of endogenous keratin IF assembly and resulted in a pathological condition equivalent to the thuman skin disease epidermolysis bullosa simplex $[9,15,51]$.

As an appraach for studying the in vivo functions of desmin and vimentin, if gene constructs based on the hamster desmin and vimentin promoters and a truncated hamster desmin gene were introduced into the murine germ line. It was previously shown that in transgenic mice expressing wildtype desmin in vimentin containing cells no developmental or morphological abnormalities could be detected, except for cataract formation [111.

Vimentin displays a complex expression pattern and is coexpressed with other IF subunits during various stages of development. When coexpressed with type III IF proteins tdesmin, glial fibrillary acidic protein and peripherin, or type IV IF proteins (neurofilaments), coassembly of vimentin and the other IF subunits takes place 16,13 , 19. 441. Hence, expression of the constructs described above is expected to affect if networks containing type III IF subunits.

We show here that expression of a truncated desmin in transgenic mice results in disruption of desmin and vimentin IFs in a significant percentage of mesenchymal cells, without causing detectable developmental or morphological abnormalities.

\section{MATERIALS AND METHODS}

\section{Plasmid construction}

For construction of pDDV the $3.4 \mathrm{~kb}$ Hincll-Hincll hamster vimentin fragment [32] containing exon 9 , the polyadenylation signal and $2.6 \mathrm{kbp}$ of $3^{\prime}$ flanking sequences, was cloned into a pUC19 digested plasmid. The $4.0 \mathrm{kbp}$ EcoRI-Sall hamster desmin fragment [33] containing $3.4 \mathrm{kbp} 5^{\prime}$ flanking sequences, including the desmin promoter region, and the $5^{\prime}$ part of exon 1 , and the $2.4 \mathrm{kbp}$ Sall-Xbal hamster desmin fragment

pDOW' P pDV
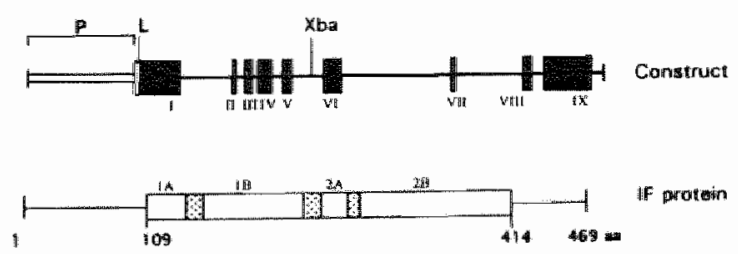

Figura 1: Schematic representation of if gene construci of pDDV and pVDV and of the resulting protein. Conm struct: black boxes represent desmin exons: white box: wimentin exon 9 tnon-codingl: striped box: coding regiom of vimentin exon $9 ; \mathrm{P}$ indicates the desmin of wimentin promoter region of the pDDW or pVDW constiruct, respectively; L: ligation site; Xba: Xbail restriction site. IF protein: white bar represents helical "rod' domain: stippled boxes: nonuhelical regions; black lines: non-helical head" and "tail" and domains. Numbers refer to amino acid (aal residues. [33] containing the $3^{\prime}$ part of exon 1 and exon $2,3,4$, and 5 , were ligated into the EcoRl-Xbal digested pUC19 vector containing the $3.4 \mathrm{kbp}$ vimentin fragment. The resulting construct pDDV contains some additional base pairs from the puC19 polylinker between the Xbal and the Hincli site (Fig. 1\%. For construction of pVDV, the $6.2 \mathrm{kbp}$ Xbal fragment from pVDes [29] was subcloned into the Xball site of pUC19, yielding pVDess-Xba. This fragment comprises the $3.2 \mathrm{kbp}$ ham. ster vimentin promoter and $3 \mathrm{kbp}$ of the hamster desmin gene. The upstream Xbal site is part of a polylinker, the Xbal' site in the desmin gene is located in intron 5. A $3.4 \mathrm{kbp} \mathrm{Hincll} \mathrm{fragment}$ containing the hamster vimentin exon 9 , the vimentin $3^{\prime}$ untranslated region, the polyadenylation signal and $2.6 \mathrm{kbp}$ of $3^{\prime}$ flanking sequences $133 \|$ was subcloned into Smal polylinker site of pVDes-Xba immediately $3^{\prime}$ of the Xbal site. Vimentin exon 9 contains 39 bp 
of coding sequences. As a result, pDDV and pVDV encode a protein of 353 amino acid residues, containing desmin amino acid residues 1-340 and vimentin amino acid residues. $452-462$ (Fig 1 ).

\section{Generation and identification of transgenic mice}

Transgenic mice were generated by pronuclear microinjection and subsequently indentified by Southern blotting as described previously [20]. For pDDV containing mice plasmid sequences were removed by complete EcoRI-Hindlll digestion leaving a $9.8 \mathrm{kbp}$ carboxy terminally deleted desmin/vimentin hybrid gene. This gene was isolated and purified as described previously [29]. The DNA concentration was adjusted to $4 \mu \mathrm{g} \cdot \mathrm{ml}^{-1}$, and \pm 200 pDDV copies were injected.

For pVDV containing mice plasmid sequences were removed by BamHI-EcoRI digestion leaving a $9.6 \mathrm{kbp}$ truncated If gene. Isolation and purification of this fragment were performed as described before $[20,29]$.

Mouse tail DNA was isolated and analyzed by Southern blotting several weeks after birth of animals that had developed from microinjected eggs.

\section{Cell culture and transfection}

Hamster lens cells [5], HeLa cells, and C2C12 muscle cells were transfected with the pDDV- or pVDV-construct using the calcium-phosphate precipitation method $[28,34,52]$. Cells were plated in $35 \mathrm{~mm}$ culture dishes (Costar Corp., Boston. MA, USA) 24-48 h before transfection and grown in DMEM (Flow Laboratories) supplemented with $10 \%$ fetal calf serum (FCS; Flow Laboratories). Transfections were carried out on cell cultures that had reached $\pm 40 \%$ confluency. $5 \mu \mathrm{g}$ Plasmid DNA was added to each culture dish as a calcium phosphate precipitate, 20 min later $2 \mathrm{ml}$ culture medium containing $5 \mu \mathrm{g} . \mathrm{ml}^{-1}$ chloroquine (Sigma Chemical Co, St. Louis, MO, USA) was added. After five hours of incubation the celis were glycerol shocked for $2.5 \mathrm{~min}$, and incubated in normal growth medium for $48 \mathrm{~h}[28,30,34,35]$. Stable transfectans for pDDV were selected as described before [34].

To induce in witro myotube formation of the C2C12 muscle cells, confluent cultures were switched to low mitogen fusion medium (DMEM supplemented with $2 \%$ horse serum; Flow Laboratories) [30].

\section{Northern blot analysis}

Northern blotting and hybridization were performed as described previously [39]. A mixture of Pstl CDNA fragments derived from pVim [10] was used as a vimentin probe. As a desmin probe a $1.8 \mathrm{kbp}$ Hindlll-Knpl fragment was used, containing most of the hamster desmin CDNA [35]. A 520 bp hamster vimentin Sau3A fragment (E49) ranging from -150 to +370 relative to the transcription initiation site, was used as a probe to simultaneousiy detect vimentin and pVDV transcripts. As an internal standard the 1.25 kbp hamster actin cDNA fragment [10] was used. This actin probe hybridizes to $a^{-}$, $B-$, and $\psi$-actin. Probes were radiolabelled using the random priming method [14].

\section{Immunocytochemistry and antibodies}

Immunofluorescence staining procedures were performed on $5 \mu \mathrm{m}$ thick cryostat sections of mouse tissues and on cultured cells as described before $[20,29 \rrbracket$ 
The following antibodies were used in this study:

1. A polyclonal rabbit antiserum (pDes) to chicken gizzand desmin [40].

2. An affinity-purified polyclonal rabbit antiserum ( $p$ Vim) to bovine lens vimentin [38].

3. The mouse monoclonal vimentin antibody RV202 1401.

\section{Immunoblotting}

Immunoblotting procedures were carried out as reported earlier 134, 411. For preparation of IF fractions from mouse tissues, $20 \mathrm{\mu m}$ thick cryostat sections from fresh frozen mouse tissues were washed for $5 \mathrm{~min}$ in PBS and centrifuged for $10 \mathrm{~min}$ at $3,000 \times \mathrm{g}$. followed by extraction in $0.5 \%$ Triton $X-100(\mathrm{BDH}$ Chemicals Ltd., Poole, UK), $5 \mathrm{mM}$ EDTA (Merck, Darmstadt, FRG), $0.4 \mathrm{mM}$ PMSF (Merck) in PBS, pH 7.4, essentially as described 1411. After centrifugation, the cytoskeletal fractions were dissolved by boiling for 4 min in SDS-sample buffer $[21]$ containing $2.3 \%$ sodium dodecylsulphate [SDS; BDH Chemicals Ltd.). Protein bands were visualized using horseradish-peroxidase conjugated swine anti-rabbit ig (DAKO AIS, Glostrup, Denmark). Blots were stained with 4-chloro-1. naphtol (Merck) and $0.12 \%$ hydrogen peroxide (Merck). Cytoskeletal preparations of cultured cells were made by harvesting the cells from culture flasks, washing in PBS and extracted with $0.5 \%$ Triton $X-100$ as described above.

\section{RESULTS}

Modifications in the C-terminal region of the rod domain of the desmin subunit can render these subunits incapable of homopolymeric fillament formation 135, 361. Moreover, expression of the mutant desmin in vimentin containing cells can cause complete disruption of the endogenous vimentin and desmin if networks $[35,36,42]$.

To study the possible function of desmin in muscle cells, a dominant negative mutant desmin gene (pDDV) was constructed (Fig. 1) under contral of $3.4 \mathrm{kbp}$ noncoding $5^{\prime}$ hamster desmin sequences. Within this $3.4 \mathrm{kbp}$ region sequences are present which contral desmin expression in myogenic cell lines $[29,24,49]$. The construct pVDV (Fig. 1) generated to investigate the in wivo and in vitro functions of vimentin, encodes a truncated desmin protein driven by the vimentin promoter. Therefore, analyses of tissues of transgenic mice expressing construct pDDV or pVDV would reveal whether the regions of the desmin- or vimentin promoter are sufficient for directing desmin expression in smooth, skeletal and heart muscle cells in vivo or vimentin expression in vimentin containing cells in vivo, respectively. The mutant encoded by the construct pDDV or PVDV, is truncated at amino acid 340 , while the last 129 amino residues of desmin are replaced by the last 13 amino acids of vimentin (Fig. 1 ).

\section{In vitro expression of $\mathrm{pDOV}$ and $\mathrm{pVDV}$}

To study the expression of pDDV and pVDV in virro, immunofluorescence studies using polyclonal and monoclonall antibodies were performed on transiently or stably transfected cell lines: 1) HeLa cells, expressing both vimentin and keratins If proteins. 2) Hamster lens cells express high levels of vimentin but no other cytoplasmic (f proteins. 3) the myogenic cell line C2C12, expressing vimentin and desmin.

\section{pDDV-expression in witro}

In undifferentiated $\mathrm{C} 2 \mathrm{C} 12$ cells stably transfected with the pDDV construct, an almast 

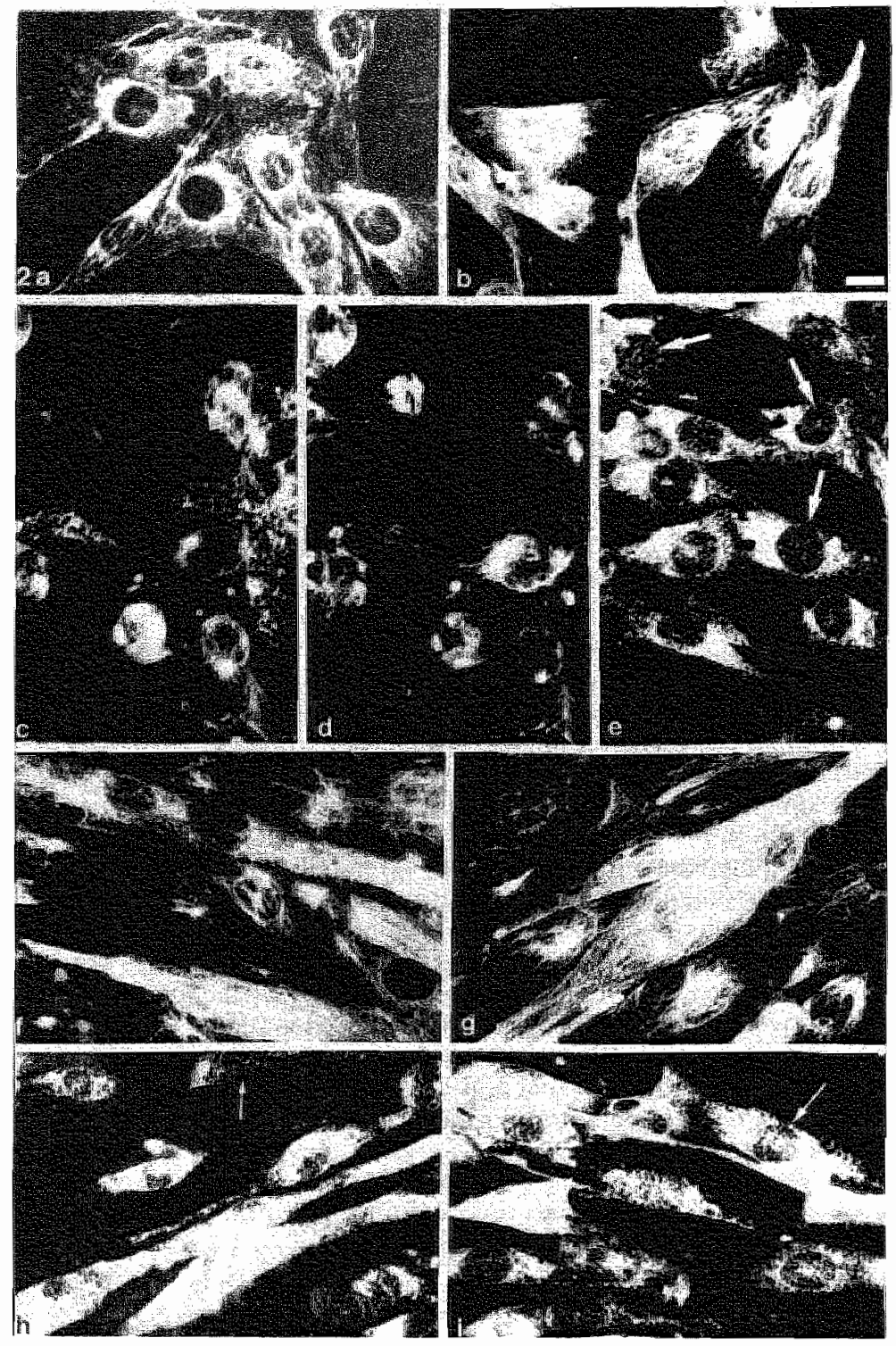

Floure 2: Simple- and double-label indirect immunofluorescence assay of control $(a, b$, $f$, all, as well as pDDV transfocted $10, d, e, h, i)$, undifferentiated $(a-e)$ and differentiated $(f, i) C 2 C 12$ cells. Cells were incubated with the polycllonal dasmin antibody $(a, c, H \times i l$, double-labelled with the monoclonal wimentin antibody (d), or labelled with the polyclonal vimentin antibody (b). Note almost complete disruption of endogenous desmin/wimentim networks in pDDV expressimg cells $(c, e, h$. $\}$. The monoclonal vimentin antibody was much less capabie of staining disturbed (dotted) desmin pattern (d). Remarkable was the dotted nuclear desmin staining pattern observed in a large number of cells (te, th; white arrowst. No clear longitudinal alignment of desmin could be observed in differentating cells expressing pDDV th, il. Bar indicates $10 \mu \mathrm{m}$. 
complete disruption of endogenous desmin and vimentin filaments was detected (Fig. 2 ). In control $\mathrm{C} 2 \mathrm{C} 12$ cells a normal filamentous desmin and vimentin pattern was detected. In a number of undifferentiated $\mathrm{C} 2 \mathrm{C} 12$ cells which expressed the pDDV construct a cytoplasmic desmin staining (filamentous, diffuse or dotted) was observed next to a dotted nuclear desmin staining in close proximity to the nucleus (Fig. 2; arrows) when using a polyclonal desmin antiserum (pDes).

In $\mathrm{C} 2 \mathrm{C} 12$ cells induced to differentiate, expression of pDDV did not result in an increase of the dotted desmin staining. The number of cells displaying a more diffuse network increased, although cells with large desmin aggregates next to filaments and dots remained present. Furthermore, dotted nuclear desmin staining was observed in differentiating cells, still showing a completely disturbed desmim/vimentin staining pattern (Fig. 2). In differentiating control $\mathrm{C} 2 \mathrm{C} 12$ cells the desmin filaments were oriented in a more or less longitudinal fashion. In the pDDV expressing celis this longitudinal desmin orientation could not be obserwed.

\section{pWDV-expression in vitro}

Transient pVDV expression in C2C12, HeLa calls, and hamster lens cells, caused complete disruption of endogenous vimentin and/or desmin filament networks as determined by indirect immunofluorescence assays using antibodies directed to vimentin and desmin. The mutant desmin and endogenous vimentin and desmin colocalized in fluorescent dots (Fig. 3).

Incubation of the pVDV transfected cells with a monoclonal vimentin antibody (RV202) resulted in a weak staining (Fig. 3b), while use of a polyclonal vimentin antibody ( $p$ Vim) yielded normal, intense vimentin staining. This suggests that the disruption of vimentin filaments and the concomitant relocation of vimentin rendered the epitope less accessible for the monoclonal vimentin antibody (RV202).

Shortly (6-8 hours) after transfection very small desmin dots were observed, indicative of llow level pVDV expression. At this stage complete disruption of endogenous vimentin/desmin networks was already observed, illustrating the dominant-negative effect of pVDV expression. Keratin filaments in HeLa cells remained undisturbed at this stagle (not shown). Later after transfection (48 hours) the majority of cells contained large clumps of mutant desmin, indicative of high levels of pVDV expression (Fig. 3). At this stage, not anly endogenous vimentin but also the keratin filament network of HeLa cells appeared to be affected by the pVDV overexpression (not showin).

\section{Expression of pDDV and pVDV in transgenic mice}

After removal of plasmid sequences both the "pDDV and pVDV constructs were intraduced into the mouse germ line via pronuclear microinjection. Southern blot analysis of tail DNA of mice born from microinjected zygotes showed that 3 out of 124 had incorporated copies of the pDDV construct and, 9 out 61 had incorporated copies of the pVDV construct into their genome. Two of the $F_{0}$-pDDV mice (strains 9 and 89 ) produced offspring which inherited the pDDV sequences. Of the nine $F_{0}$-pVDV mice $\left(F_{0}\right.$-strains 5,7 , $9,33,47,50$ and 551, seven produced offspring which inherited the pVDV construct. Southern blot analysis revealed no detectable rearrangements in both constructs (not shown). Offspring from pDDV-founders 9 and 89 contained -2 copies, while in offspring from pVDV-founders copy numbers varied from 2 to -50 . All transigenic mice appeared healthy.

Mouse tissues of pDDV- and pVDV-mice were dissected and split in two. One part was used for RNA analysis, the other part was used for immunofluorescence and immunoblotting assays. Polyclonal antibodies to desmin (pDes) and vimentin (pVim) were 

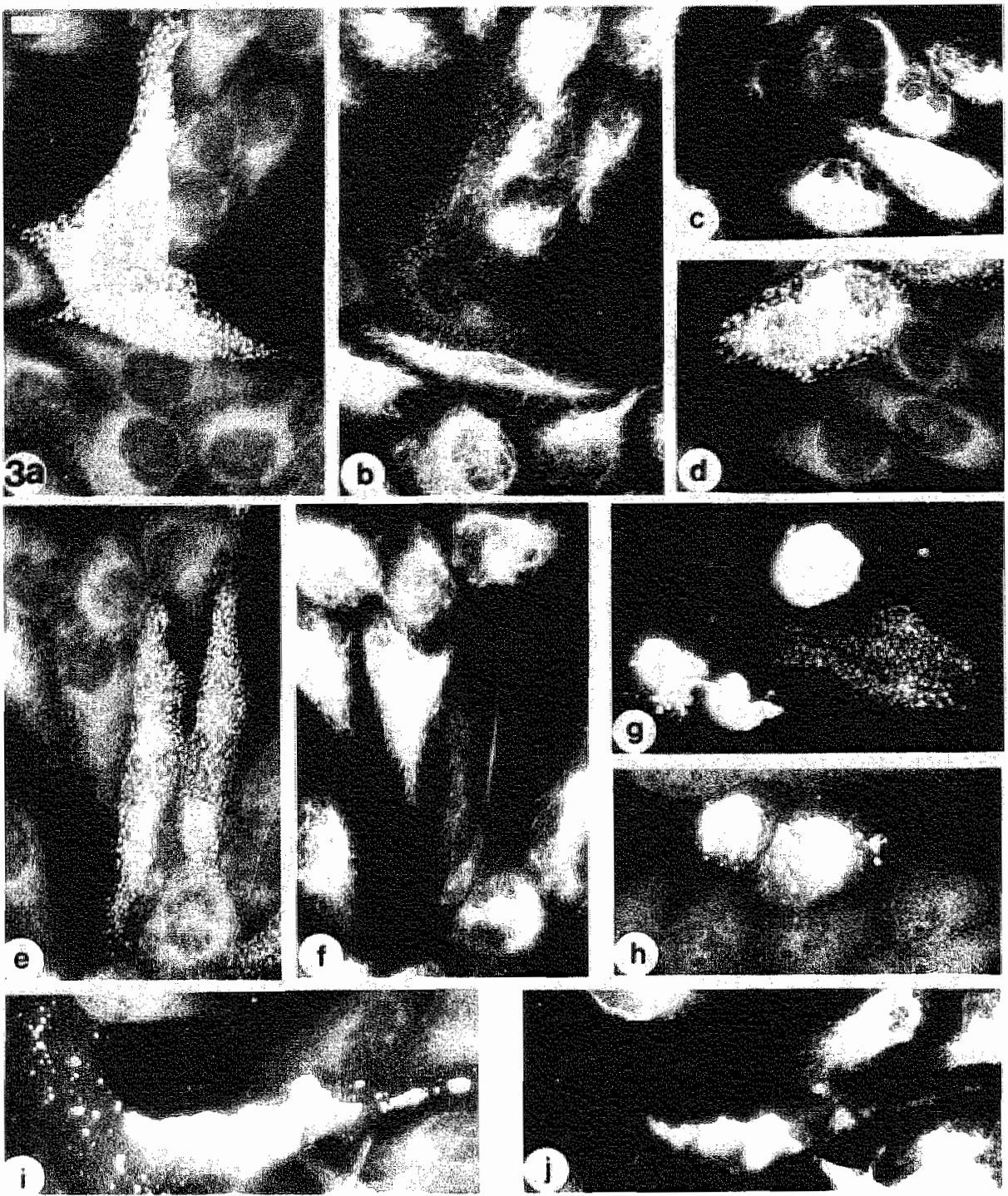

Figura 3: Single- and double-label indirect immunofuorescence assay of Hela cells and hamster lens cells tramsiently transfowted with pVDV. Cells were incubated with polyclonal antisera to desmin lpDes! and vimentin $(p$ Viml. a d) Double label staining with pDes (a, d) and a monoclonal antibody to vimentin (AV202; $b, c)$ of pVDV transfected Hela cells, showing a punctate staining pattern. $e, f, i, j$ Hamster lens cells double-labelled with the polyclonal desmin antiserum lpDes; $e_{*}$ if and the polyclonal wimentin antisarum lp Vim: fi. Note the complete disruption of vimentin filaments, absence of intact mutant desmin filements, and colocalization of mutant dosmin and wimentin. g, h) Staining with the polyclonal desmin antiserum lpDes) of HeLa cells, expressing pVDV at relatively low (punctate stainingl or very high levels tcells thlled with mutant desmint. Bar indicates 10 mm. 

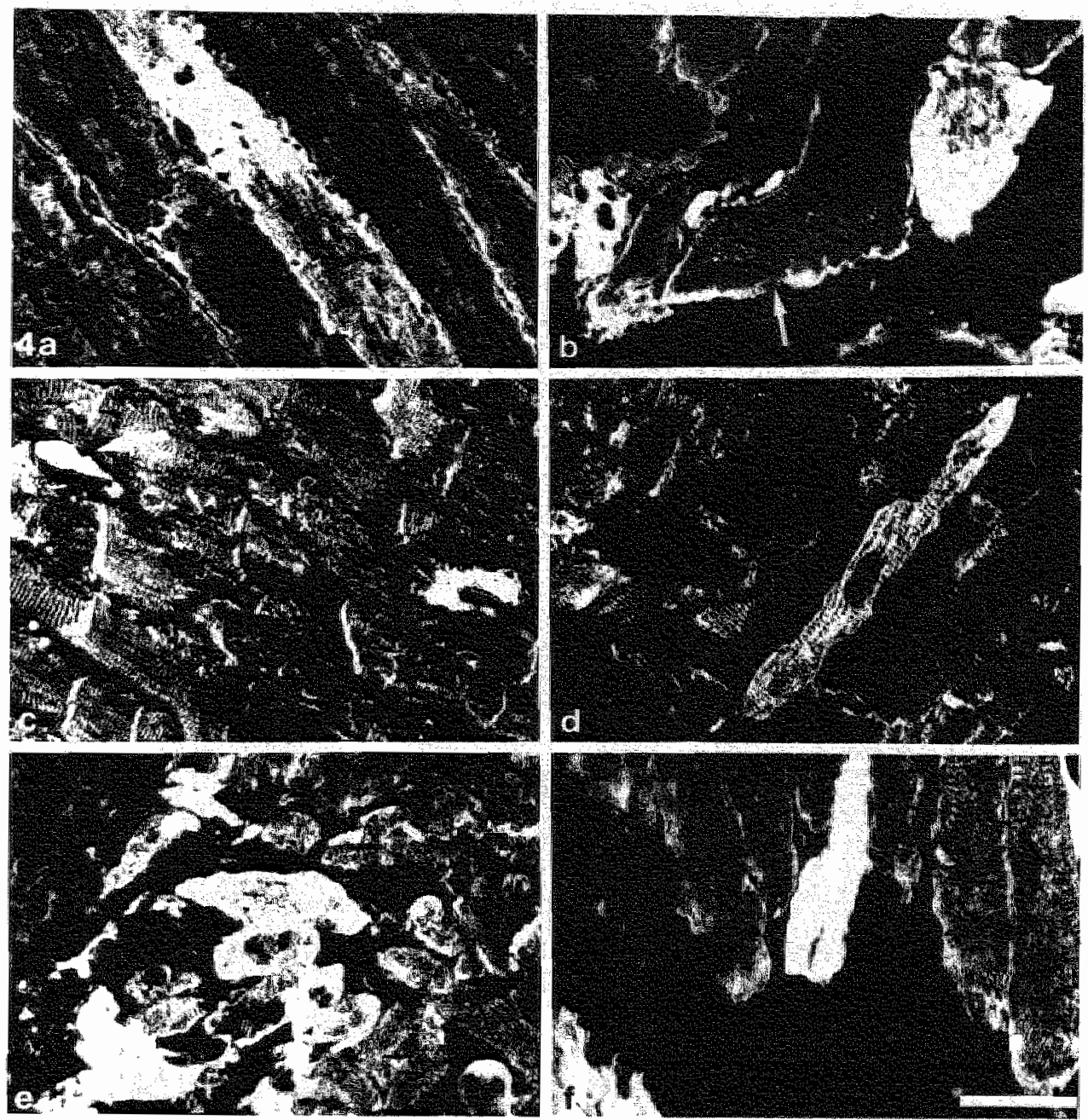

Figure 4: Indirect immunofluorescence microscopy of tissu sections derived from pDDV transgentic mouse 43 loffspring of strain 91. Section were stained with the polyclonal desmin artibody. Mn skatetal muscle $(a$, b) a strong difuse fuorescence staining patten was obserwed in some strited truscla cells. In some cells a dotted desmin staining, mext to the diffuse reaction was present lb; arrowi. In heart sections only very few cells displayed the strong diffuse destrin staining pattern lor arrowl. whereas some cells showed only a weak diffuse desmin reaction (d). The strongest diffuse staining intemsity was observed in striated muscle cells of the tongue le\}. In esophagus, onfy a very few cells displayed

used in these latter assays.

\section{pDDV-expression in mouse tissues}

Sections of different tissues of $F_{0}$-mice and their offspring expressing pDDV were analyzed for desmin and vimentin expression. Using the immunofluorescence technique, 

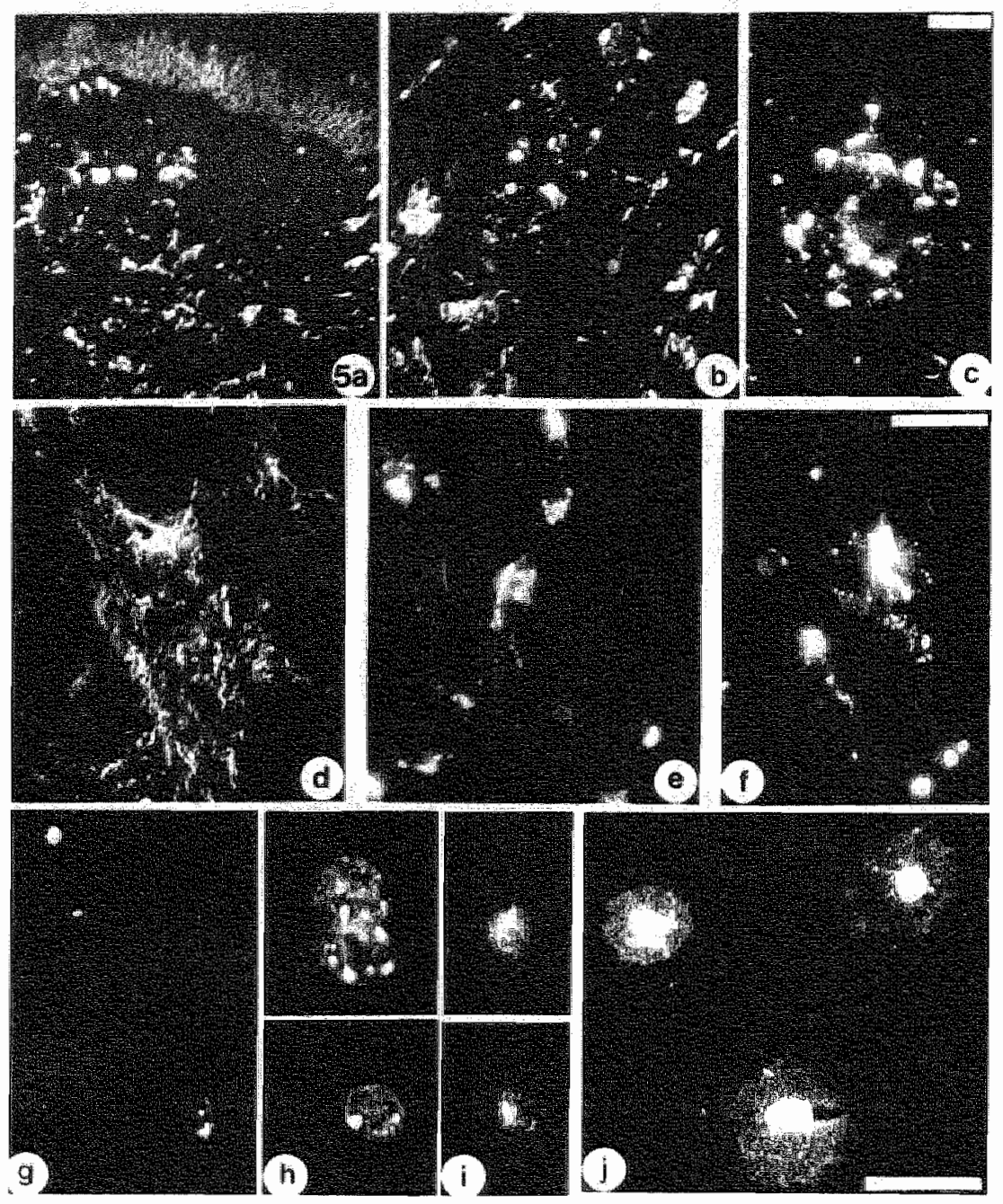

Figure 5: Indirect immunofluorescence microscopy of tail sections (a-fl and blood cells lo-jil from trangenic pVDV mice. using polyclonal antisera to desmin and vimentin. a-ch Steining of tait sections of mowse strains $47(a), 55(b)$, and 50 lc) whth the polyclonal desmin antisenum. Note the strongly fluorescent dots and clumps (not observed in control hissuel in connective tissue. dufy Tall sections mouse strains 47 (d, el, and 55 (f), stained with the polyclomat vimentin antiserum. Vimentin expression was detected in wirtually all connective tissue id). while pWDV expression was detected in a minotity of connentive tissue ficompare a-c to dh ldentification of connective tissue containing completely disupted vimentin filwments using the polvelonal vimentin antibody pwim was hampered by the presence of many cells containing intact flaments. Howewer, in areas less densely packed with mesenchymal cells complete wimemtin distuption could be observed le, $f$. g and hl Blood smears from stigins 47 lol and 55 thy incubated with the polyclonal desmin antibody pDes. Note strongly fluorescent dots and clumps fnot observed in control blood cells) in a small percentage of blood cells. i and j) Blood smears of strains 47 (ill and 55 (j) staned with the polyclonal wimentin antiserum puim. Note complete distuption of vimentin filaments in blood cells (i; lower panell). Also partial disruption was observed in these cells (i; upper panel). Bars indicate $4 \mathrm{~mm}$. 

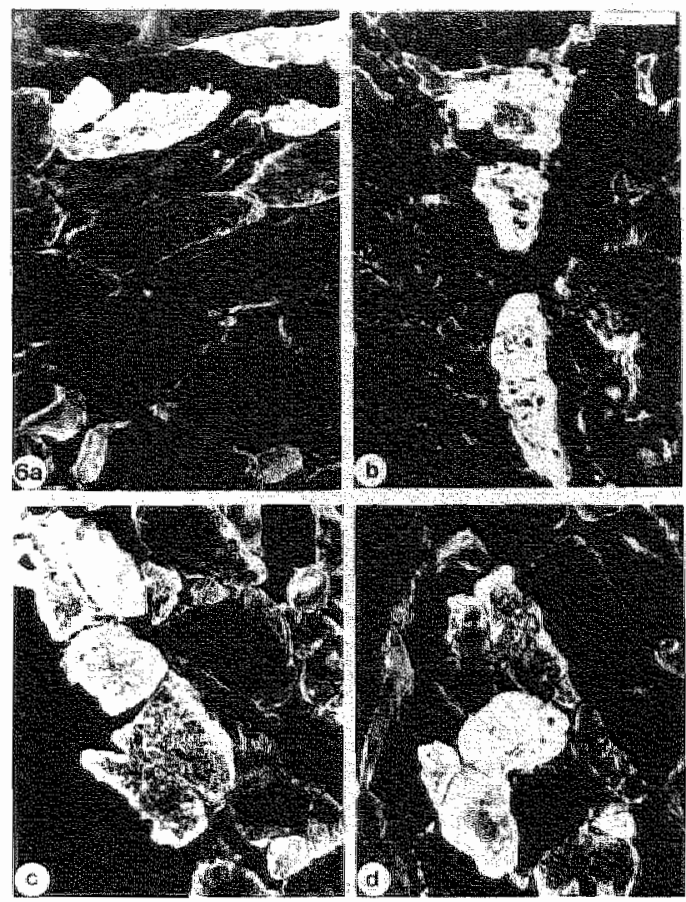

Figure 6: Indirect immunafluorescence microscopy of skeletal muscle $(a, b)$ and cross-striated muscle cells of the tongue $\left(c_{8}\right.$ d) from pVDV transgenic innice 47 $(a, c)$ and $50 \quad(b$, d), using the polyclonal desmin antiserum. Note strongly fiuorescent, diffuse desmin staining (not observed in non-transgenic micel in a minority of muscle fibers. The striated pattern normally observed upon desmin staining was also present in these muscle fibers. Bair indicates $10 \mu \mathrm{m}$.

skeletal muscle and cross-striated muscle of tongue and esophagus showed a divergent staining pattern in faw $(<1 \%)$ muscle cells, as detected with the polyclonal desmin antibody (pDes). A very

strong, diffuse staining pattern could be observed in these cells (fig. $4 \mathrm{a}, \mathrm{b}$ ). while in a few cells desmin dots were seen (Fig. 4b: arrow). In the non-affecm ted muscle colls a normal cross-striated staining pattern was detected. In heart muscle of pDDV-mice only occasionally a diffuse staining pattern was observed (Fig. 4c, d; arrow indicates a pDDV positive cell). The staining intensity in affected heart cells was less as compared to the affected cells observed in skelletal muscle. Also in striated muscle cells of the tongue a strong diffuse staining could be detected in $\pm 1 \%$ of the cells (Fig. 4e). In tissue sections of esophagus, pDDV positive skeletal muscle cells were only occasionally detected (Fig. 4f, arrow). In all pDOV positive cells desmin cross-striation did not seem to be affected by the mutant desmin expression, however, in areas with extremely high mutant desmin expression this could not be determined. No abnormal staining pattern with the polyclonal desmin antibody (pDes) was fround in smooth muscle cells, while in tissue sections of kidney, liver, spleen and testis a normal desmin expression pattern was seen in smooth muscle cells and myoid cells (data not shown.

Using the polyclonal vimentin antibody (pVim) the pDDV expressing, crossustriated muscle cells in tongue, esophagus and heart showed a weak, diffuse staining pattern, in comparison to the desmin staining pattern. In skeletal muscle a relative sitrong reaction was obtained in cells containing the pDDV-construct. This staining was as strong as the desmin staining described above. In other tissues no abnormal vimentin staining pattern was detected.

\section{pVDV-expression in mouse tissues}

Tail sections of a number of offspring of pVDV-mice showed a punctate staining pattern in connective tissue cells (fibroblasts, endothelial cells) with the polyclonal desmin antibody (pDes) (Fig. 5a, b). Surprisingly, pVDV expression could not be detected in all vimentin expressing cells. In the tail tissue sections about $1 \%-5 \%$ of the connective tissue cells were stained with the desmin antibody. The percentage of cells comtaining detectable levels of mutant desmin varied considerably between litter mates.

Immunostaining of blood cells using the pDes antiserum resulted in a positive staining of leucocytes, where mutant desmin spots and clumps could be observed (Fig. $5 \mathrm{~g}$, h). 


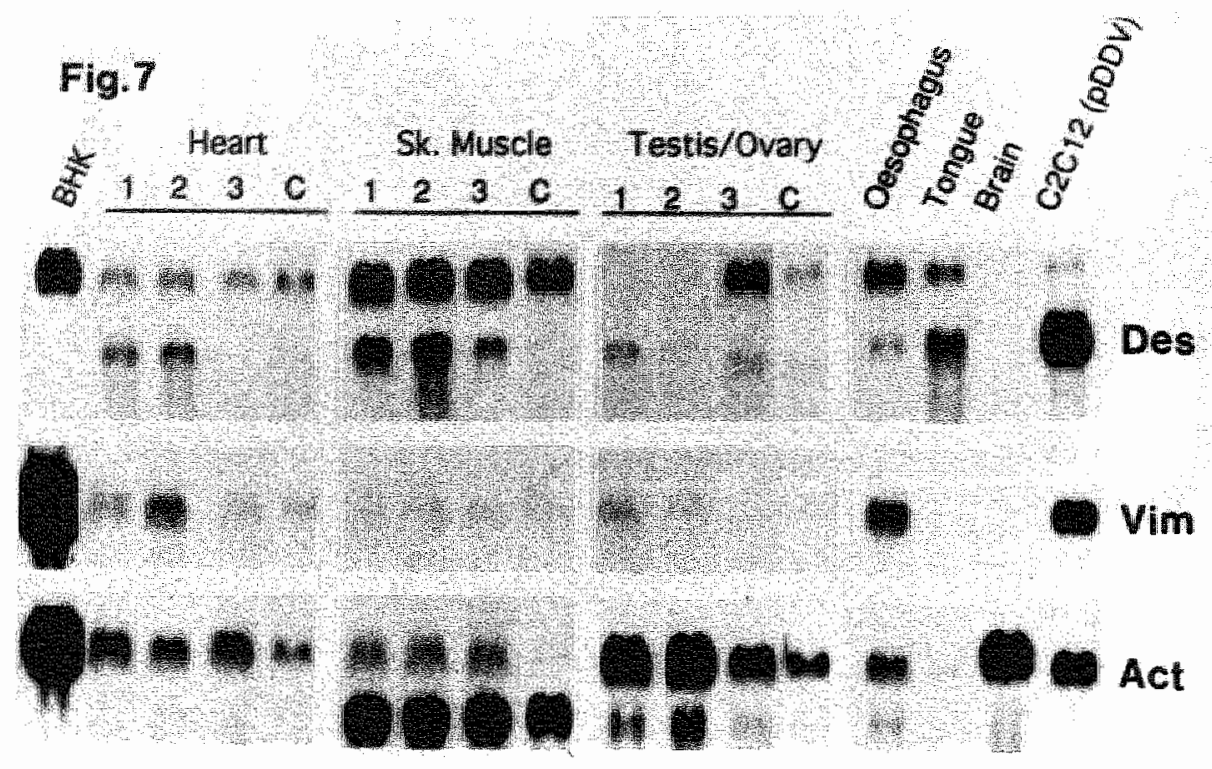

Figure 7: Northern blot analysis of $10 \mu \mathrm{g}$ of total ANA isolated from different transgenic pDDV mouse tissues. Blots were probed with desmin (Des), vimentin (Vim), and actin (Act) probes subsequently. Lanes 1 and 2 represent offspring of pDDV strain 9; lane 3 represents offspring of pDDV strain 89; lane C represents a control mouse which did not carry the pDDW construct. pDDV mRNA was only de tected in musche tissue of mice carrying the pDDV construct llanes 1-2). pDDV mANA was detected in heart, skeletal muscle, cross striated muscle cells of tongue and esophagus and in testis (for details see textl. No mutant transcript was detected in spleen, kidney, ovary, brain, and liver.

Staining with the polyclonal vimentin antibody (pVim) revealed that expression of the truncated desmin caused disruption of the vimentin filaments in these blood cells (Fig. 5i. j).

Also other tissues of pVDV-mice were sectioned and stained with the polyclonal antibodies to desmin ( $\mathrm{pDes}$ ) and vimentin ( $\mathrm{pVim}$ ). A normal staining pattern was detected with these antibodies in sections of heart, esophagus, kidney, liver, spleen and testis. In contrast. skeletal muscle and the cross-striated muscle cells of tongue, showed diffusely stained cells with the pDes and the pVim antisera (Fig. 6). Expression of mutant desmin was observed in $\pm 11 \%$ of the cross-striated muscle cells. No fluorescent dots or clumps could be observed, but instead the staining pattern was diffuse and much more intense than endogenous desmin staining, suggestive of high levels of mutant desmin expression (Fig. 6). Control sections of non-transgenic mice did not display this staining pattern.

Using the pVim antibody the same staining pattern was detected in the mutant desmin containing cells. In connective tissue cells and blood cells without a mutant desimin staining pattern, a fila-mentous vimentin staining pattern was occasionally observed. No vimentin staining was seen in cross-striated muscle cells without a mutant desmin staining pattern.

The strong diffuse desmin staining reaction in cross-striated muscle cells must be mainly the result of mutant desmin expression and can only to a minor extent caused by ondogenous mouse desmin. This conclusion is based on the fact that staining with polyclonal antibodies against vimentin, resulted in the same diffuse, strongly fluorescent staining pattern as seen for pDes (not shown).

The overexpressian of PVDV and the concomitant disruption of the endoge-nous vimentin filament network in a significant percentage of stromal-and blood cells did not seem to 


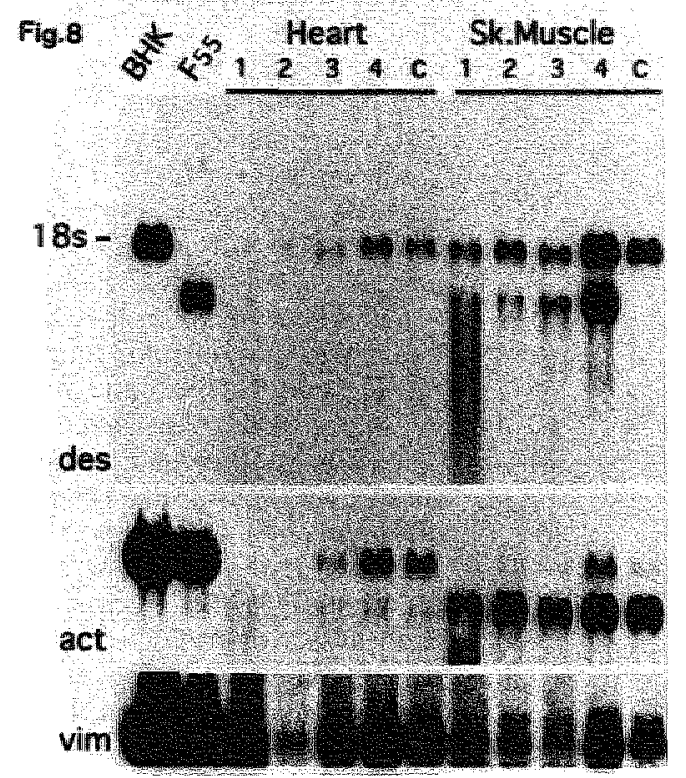

Figure 8: Northern blot analysis of $5 \times 20 \mu \mathrm{g}$ of total RINA from transgenic pVDV mouse strains 47,50 , and 55, isolated from heart, skeletal muscle. Blors were subsequently hybridized to a desmin a wimentin, and an actin probe. The actin probes recognizes both $a-11.8 \mathrm{kbp})$ and B/y-actin transcripts (2.1 kbpl. Between hybridizations, blots were stripped. Total RNA $\{1-2 \mu$ from desmin and vimentin expressing $\mathrm{BHK}-21$ cells and from $\mathrm{pWDV}$ expressing fibroblast cell lime $55 \quad\left(F_{o}-55\right)$ were transgenic control mouse: lanes $11 \mathrm{~F}_{2}$-mouse 55 ; lanes 27 strain $F_{1}-55$; lanes 3) $F_{1}$-strain 47 ; lanes 4 ) strain $F_{y}-50$. Note high levels of pVDV expression in skeletal muscle. included as controls. Lanes CI FNA from a non.

cause detectable developmental "morphological or physiological abnormalities.

Levels of pDDV and pVDV mRNA in transgenic mice

Expression of pDDV and PVDV mANA, and its influence on endogenous desmin and vimentin expression levels. were analyzed by Northern blotting using mRNA of heart, skeletal muscle esophagus, tongue, spleen, kidney, liver and testis or ovary. Blots were hybridized to desmin, vimentin, and actin specific probes, subsequently. Actin mRNA levels served as standard. After each hybridization, blots were stripped before the next hybridization was performed. In muscle tissue of control mice only the endogenous desmin mRNA was observed. Expression levels were determined by densitometric scanning of autoradiographs from Northern blots containing equal amounts of RNA.

\section{IMRNA-levels of pDDV}

As compared to non-transgenic mice, in skeletal muscle tissue of the mice transgenic for pDDV (strains $F_{0}-9$ and $F_{0}-89$ ) an additional band was present next to the desmin mRNA band, corresponding to the correctly sized pDDV transcript (Fig. 7). The levells of endogenous desmin and vimentin mFNA did not differ significantly between control and transgenic tissues. The amount of pDDV transcripts present in offspring of pDDV strains 9 and 89 varied between animals derived from these two founders. In offspring of pDDV strain 9, skeletal muscie (amount of pDDV transcript equals endogenous desmin transcript) and tongue (pDDV transcript twice the endogenous desmin level) displayed the highest expression levels. Also in esophagus (pDDV transcript 0.5 times endogenous desmin llevely and testis (but not in ovary) mutant transcripts were found. Offspring of pDDV strain 9 contained mutant transcripts in myocard, whereas in offspring of pDDW line 89 this could not be detected (Fig. 7). The levels of transcripts present in heart musche of offspring of pDDV strain 9 varied between 0.5 to 2 times that of endogenous mRNA (not shown. In general, expression levels in offspring of pDDV strain 89 were lower compared to the expression levels in offspring of pDDV strain 9 . No mutant transcripts could be detected in tissue sections of the brain, spleen, kidney and liver. These Northern blatting results clearly demonstrate that pDDV expression is limited to muscle tissue. 


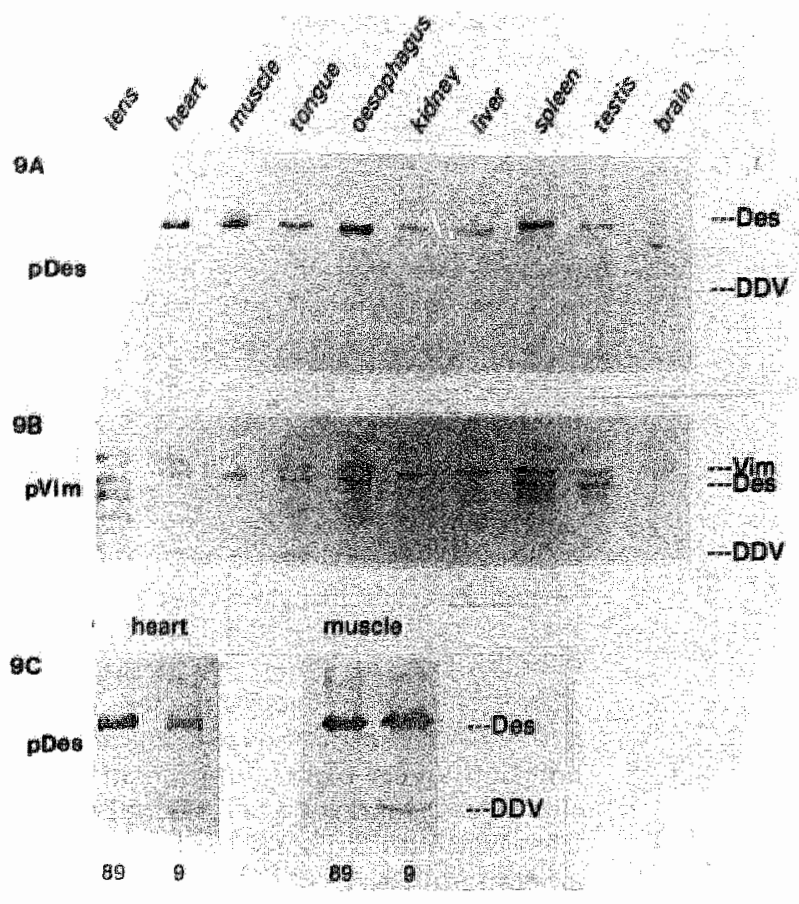

Figure 9: Western blot analysis of extracts from tissues of transgenic pDDV mouse 43 loffspring of strain 9\%. Blots were incubated with the polyclonal desmin antiserum (panel Al and subsequently with the polvclonal vimentin antiserum (panel B). Mutant pDDW protein was only detected in heart, skeletal muscle "tangue and asophagus. Note that the amount of mutant protein is much lower than endogenous desmin protein. Only a low level of vimentin was present in skeletal muscle, as compared to heart, tongue and esophagus. Panel $C$ shows the difference in pDDV expression between $F_{n}$-mice 89 and 9 .

Since mouse strains 47,50 and 55 exhibited the nighest pVDV expression levels, they were used for a more detailed analysis of the tissue-specificity and levels of transgene expression. Total RNA samples from various tissues, including heart, skeletal muscle, tongue, spleen. liver, kidney and testis or ovary. were analyzed by Northern blotting (Fig. 8). The three independent strains displayed similar expression patterns of the correctly sized $(1.7 \mathrm{kbp})$ pVDV transcript. High levels of pVDV expression, in the same range as endogenous desmin, were detected in skeletal muscle (Fig. 8) and tongue. In contrast, heart pVDV transcript levels were at the threshold of detection (Fig. 8). Some pVDV expression was detected in esophagus and testis.

Clearly, pVDV expression did not follow the endogenous vimentin expression pattern. Skelletal muscle tissue expresses onlly low levels of vimentin, while in heart tissue much more vimentin is present (Fig. 8).

\section{Mutant desmin protein levels in transgenic mouse tissues}

\section{Western blatting of pDDV tissues}

Western blots of protein extracts derived from the transgenic pDDV mouse tissues were incubated with a polyclonal desmin antibody (pDes; Fig. 9) and a polyclonal vimentin antibody (pVim; Fig. 9). Staining with the pDes antibody demonstrated that the pDDV encoded protein could only be detected in cross-striated muscle of heart, skeletal muscle. tongue and esophagus at $40 \mathrm{kDa}$ (Fig. 9A). After staining with the pVim antibody in all tissues the endogenous $57 \mathrm{kDa}$ vimentin could be detected, while with the vimentin antibody only in skeletal muscle, heart, esophagus and tongue the pDDV product could be found (Fig. 9B). No mutant desmin was detected in testis. In all other tissues investigated no pDDV encoded protein could be detected. The amount of pDDV protein observed in offspring of pDDV strain 89 was always lower (at the tresholl of detection) than the amount of pDDV protein in tissues of offspring of pDDV strain 9 . Furthermore, no pDDV protein was found in heart muscle in offspring of pDDV strain 89 (Fig. 9C. lane 89). 


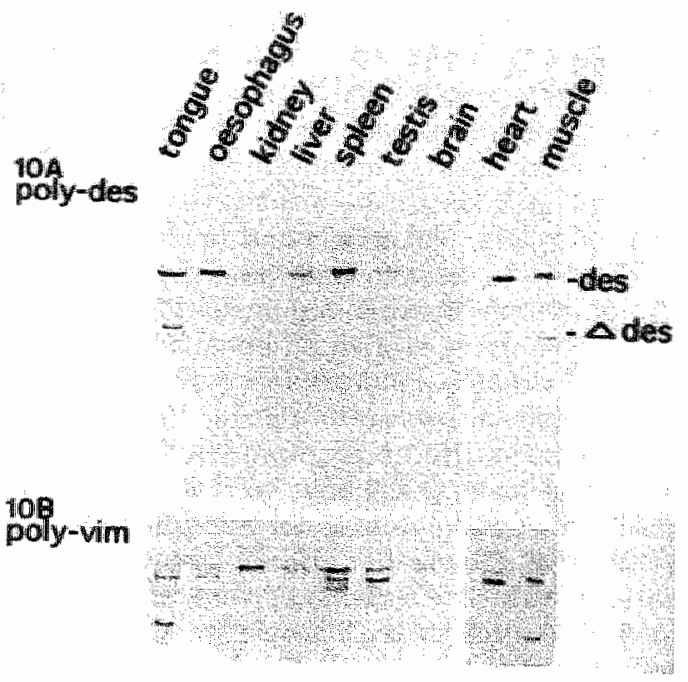

Figure 10: Western blot analysis of cytoskeletal fracthons of tissues derived from pVDV transgenic $F_{2}$. mouse strain 47 . The bllot was incubated with the polyclonal desmin antiserum (panel A) and subsequently with the polyclonal vimentin antiserum fpamel B). The endogenous desmin pratein ldes; $53 \mathrm{kDal}$ and the pWDV encoded protein $1 \triangle \mathrm{des}$; $40 \mathrm{kDal}$ are indicated. Mutant desmin expression was detected in skele. tall muscle and tongue tissue.
Wiestern blothing of pVDV tissures

Mouse tissues of transgenic pVDV mice of offspring of $F_{5}$-mice 47,50 and 55 were used for Western blotting. Protein extracts (Fig. 10A, C) of tongue, esophagus, kidney, liver, spleen, testis. ovary (not shown), brain. me lens (not showni, heart muscle and skeletal muscle were used.

Correctly sized (40 kDa) pVDV encoded protein was detected in skeletal muscle and tongue (Fig. IOA) and at the treshold of detection in eye lens tnot shown. The endogenous desmin 153 $\mathrm{kDa}$ ) was found in tongue, esophagus, kidney, spleen, liver, testis, ovary (not shown), heart and skeletal muscle. No endogenous desmin could be detected in brain and eve lens. With the pvim antibody (Fig. 1OB) only in tongue and skeletal muscle the $40 \mathrm{kDa}$ pVDV prow tein was detected, while in all tissues the endogenous $57 \mathrm{kDa}$ vimentin was observed.

\section{DISCUSSION}

As an approach to studying in wivo functions of desmin and vimentin, constructs encoding a truncated desmin protein, were introduced into the murine germ line. Transgenic mice express-ed the truncated desmin protein in different cell types, depending on the promoter used in the construct. The truncated desmin protein was chosen on basis of its ability to disrupt both endogenous desmin and vimentin IF networks. This effect was first proven in cell culture studies.

Disruption of mouse desmin and vimentin filaments by pDDV and pVDV expression in vitro

Interaction of the mutant and wildtype IF subunits resulted in disassembly of preexisting type III IF networks and inhibits de novo If formation $[2,9,16,22,25,34,35,36,42$. 51.531 .

Expression of pDDV resulted in an almost complete distuption of endogenous desmin and vimentin IF structures in undifferentiated $\mathrm{C} 2 \mathrm{C} 12$ cells, proving that the protein derived from pDDV has a truly dominant negative effect on type III IF filaments. However, in differentiating cells, the dominant negative effect seemed to be partially compensated by the increase of endogenous desmin expression, although the effect might also be explained by the relative instability of the mutant desmin protein [35]. However, compared to control cells, differentiating pDDV expressing cells showed a disturbance of 
desmin/vimentin filament organization. This resulted in diffuse, hazy filamentous next to dotted staining in myotubes. Furthermore, in differentiating cells no clear longitudinal alignment of desmin was observed. These observations demonstrate that expression of pDDV in myotubes interferes with some basic structural processes in these cells, and therefore should also be capable of interfering with desmin organization in muscle of transgenic mice in vivo.

Expression of the pVDV construct in hamster lens cells, HeLa cells and undifferentiated $\mathrm{C} 2 \mathrm{C} 12$ cells caused a dominant-negative effect on the desmin and vimentin networks. We conclude that pVDV expression caused disruption of vimentin and desmin filaments in vitro, while Raats [37; thesis] and Pieper [31; thesis] have shown an enhanced turnover of the endogenous IF subunits in such cases. A remarkable phenomenon was observed in cells expressing pDDV. In a number of cells cytoplasmic desmin staining (filamentous, diffuse or, dotted) was observed next to, what appeared to be a dotted nuclear staining (Fig. 2e, white arrows). Confocal scanning laser microscopy will have to reveal the exact localization of these structures. These nuclear dots were only observed using a polyclonal desmin antibody. In a previous study [12] it was also shown that in cells stably transfected with C-terminally deleted vimentin subunits, dotlike structures were formed in the nucleus, next to filamentous, dotted and diffuse structures in the cytoplasm. C-terminally deleted keratin filaments have also been observed in the nucleus, were they formed fillamentous as well als dotted structures [3]. In contrast to previlous observations with myogenic cells expressing a comparable desmin protein under control of the RSV promoter 1421 , differentiation of C2C12 cells expressing PDDV and pVDV, did not result in an increase of dotted desmin staining.

\section{Regulation of pDDV and pVDV expression}

It remains to be elucidated why pDDV is only expressed in cross-striated muscle cells and not in smooth muscle cells. It was previously shown that in transgenic mice a vimentindesmin hybrid gene (pVVim2, [201) and a complete desmin gene (pVDes, [29]), both under control of the vimentin promoter, were expressed in virtually all vimentin-producing cells. The pVDes expression pattern was slightly more restricted than that of endogenous vimentin and pVVim2 (no pVDes expression in testis Sertoli and Leydig cells; expression in a subset of vimentin positive cells in some tissues $[11,291)$, and pVDes expression levels were lower. The expression pattern of pVDV in turn appears to be more restricted than that of pVDes. In both cases, regullatory elements present in one construct may be missing from the other.

Vimentin is not expressed in mature myotubes $[19,23,28,46,50]$. The expression of pVDV in myotubes might be caused by the lack of negative control elements from the vimentin gene suppressing expression in myotubes. However, it have been shown proviously $[23 ; 28]$ that the vimentin promoter is sufficient for downregulation of vimentin expression during myogenesis. Altematively, positive control elements stimulating muscle-specific expression may be present in the desmin gene derived part of pVDV. This would imply that regulatory elements located in different parts of the desmin gene are involwed in in wivo desmin expression, since it has been shown $[24,28]$ that the $5^{\prime}$ flanking region of the desmin gene contains sequences capable of driving high level, muscle. specific expression in cultured myogenic cells.

\section{Disruption of desmin IF in muscle}

During myogenesis, the longitudinally oriented IFs undergo phosphorylation-mediated disassembly and are redeployed to a transverse association along the $[-Z-\mid$ bands [46]. Whille intact desmin filaments may be dispensible for in vitro myogenesis [42], it has been 
shown that in vitro myoblast fusion is inhibited when disassembly of longitudinal desmin filaments is blocked by injecting desmin phosphorylation site-specific antibodles [45]. The concomitant occurrence of striated and diffuse staining desmin patterns observed in this study may indicate that the mutant desmin is not capable of interacting with endogenous desmin, thereby leaving the process of myogenesis undisturbed. Conformation of this notion requires electron microscopic analysis of mutant desmin expressing musicle fibers.

\section{In vivo functions of desmin and vimentin}

It has been demonstrated that desmin and wimentin filaments are dispensible for in witro myogenesis [42]. Similarly, expression of truncated vimentin did not cause detectable abnormalities during early embryogenesis in Xenopus laevis. [8]. Furthermore, inactivation of both keratin 8 alleles in embryonic stem cells did not inhibit differentiation into yolk sac-like embryoid bodies [4]. However, disruption of keratin filaments in the skin of transgenic mice [9, 15, 511, in Xenopus laevis oocytes $\llbracket 47]$, and in $F 9$ embryonal cells [48] by dominant negative mutation revealed that keratins can have an important function in providing mechanical support to warrant structural integrity of cells and tissues, demonstrating the feasibility of studying If function by this approach. The important questions that results from this study is why the pDDV and pVDV expressing mice do not display an abnormal phenotype?

The pDDV and pVDV transgenic mice described here expressed mutant desmin in a minority of desmin- and/or vimentin-expressing cells, respectively. If desmin and vimentin function at the level of tissues or organs $1191, e .9$. , by imparting structural integurity to the cell in the context of its tissue, then the cells expressing the truncated desmin may be 'rescued' by non-expressing neigbouring cells. pVDV-expressing cells which do not constitute a solid tissue, such as blood cells, may be incompetent for certain functions, but non-expressing cells could substitute for the defective cells.

The generation of transgenic mice expressing the truncated desmin in all desmin (pDDV) or vimentin ( $p$ VDV) containing cells, or inactivation of the mouse desmin or vimentin genes via homologous recombination in embryo stem cells may be necessary to elucidate the functions of both desmin and vimentin IFs.

\section{REFERENCES}

1. Abe M. Oshima RG. A single human keratin 18 gene is expressed in dwerge apithelial colls of transgenic mice. J. Coll Biol. 111, 1197.1206, 1990.

2. Abers $K$, Fuchs $E$. The expression of mutant keratin 'roDNAs transfocted in simple weithelal and squamous cell carcinoma cell lines. J. Cell Biol. 105, 791-806, 1987.

3. Bader BL, Magin TM, Freudenmann M, Stumpp S, Frankg WW. Intermediate fillaments tomed dk novo from tailless cytokeratins in the cyttoplasm and in the nucleus. $J$. Cell Bitol. 115, 1293-1307, 1991.

4. Baribault $\mathrm{H}$. Oshima RG. Polarized and functional epithelia can form after the tairgetedinactivation of both mouse keratin 8 alleles. 1. Call Biol. 115, 1675-1684, 1991.

5. Bloemendal $H$, Lenstra JH, Dodemont $H$, Ramakers FCS, Groeneveld A, Dunia 1 , Benedetti EL. SV40-transformed hamster lens epithelial cells: a novel system for the isolation of cytoskeletal messenger RNAs and their transtation products. Exp. Eye Res. 31, $513-525,1980$.

6. Bloemendal $H$, Pieper FA. Intermediate filaments: known structure, unknown function. Biochem. Biophys. Acta 1007, 245-253, 1989.

7. Capetanaki Y. Smith S. Heath JP. Owerexpression of the chicken vimentin gene in transgenic mice inhibits normal lens cell differentiation. J. Cell Biol. 109, 1652 $1664,1989$.

8. Christian JL, Edelstein NG. Moon AT. Overexpression of wild type and dominamt negative mutant vimentin subunits in developing Xenopus embryos. New Biot, 2,700-711, 1990 .

9. Coulombe PA, Hutton ME, Letai A, Hebert A, Paller AS, Fuchs E. Point mutations in humankeratin 14 genes of epidermolysis bullosa simplex patients: genetic and functional analyses. Cell 66 . $1301-1311,1991$. 
10. Dodemont HJ. Soriano P. Quak WJ. Ramakers FCS, Lenstra JA, Groenen MA, Bernardi G, gloemendal H. The gerves coding tor the cytoskeletal proteins actin and wimentin in warm-blooded wertebrates. EMBO J. 1, 167 171, 1982.

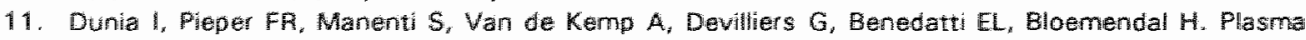
membranecytokkellor damage in eye lenses of transgenic mice expressing desmin. Eur. il. Cell Biol. $53,59-74,1990$.

12. Eckett A, Herriann $H$. Franke WW. Assembly of tailless mutant of the inemediate thament protein vimentin in witro and in vivo. Eut. S. Cell Biol. $58,319-330,1992$.

13. Eriksson JE, Opal P, Goldman AD. Intermediate filament dynamics. Curp. Op. Cell Bid. 4, 99-104, 1992

14. Feinberg AP, Vogelstein B. A techirique for radiolabelling DNA restriction endonuclease fragments to thigh specific activity. Addendum. Anal. Blochem. 137, 266-267, 1983.

15. Fuchs E, Coulombe PA. Of mice and men: genetic skin diseases of keratin. Cell $69,899.902$. 1992.

16. Gill $5 \mathrm{~A}$. Wong PC, Monteiro MJ, Clevelarid DW. Assembly properties of daminant and recessive mutations in the small mouse neurofilament (W.F-L) subunit. J. Cell Biol. 111, 2005-2019, 1990.

17. Janmey PA. Eutenever U. Traub P. Schliwa M. Viscoelastic properties of vimentin compared with other fllamentou biopolymer networks. J. Cell Biol. $113,155-166,1991$.

18. Julien J. Tretjakolf 1 , Beaudet $L$, Peterson A. Expression and assembly of human neurotilament protein in transgenic mice provide a novel meuronal marker system. Genesi Devel. 1, 1085-1095, 1987.

19. Klymkowsky MW, Bachant JB, Domingo A. Functions of intermediate filaments. Cell Motil. Cytoskel. 14, 309-331, 1989.

20. Krimpenfort PJ, Schaart G, Pieper FR, Cuypers HT, Van den Heuvel AM, Vree Egberts W, Van Eys GJ, Berns A, Eloemendal H. Tissue-specilic expression of a vimentin-desmin hybrid gene in transgenic mice. EMBO J. 7, 941.947, 1988.

21. Laemmili UK. Cleawage of structural proteins during the assembly of the head of bacteriophage T4. Nature 227, 680in685, 1970.

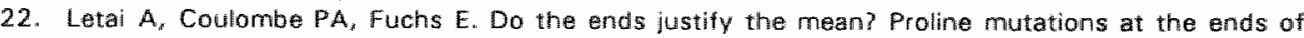
keratin coled-coil rod segment are more disruptive than internal mutations. ل. Cell Biol. 116. $1181-1195,1992$.

23. Li Z, Lilienbaum A, Butler-Browne $G$, Paulin D. Human desmin coding gene: complete nuicteotide sequence, characterization and regulation of expression during myogenesis and development Geine $78,243-254,1989$.

24. Li $Z$, Paulin D. High level desmin expression depends on a muscle-specific enhancer. $J$. Biol. Chem. 266, 6562-6570, 1991.

25. Monteiro MJ, Hoffmanin PN, Gearhart JD, Clevelland D. Expression of $N F-L$ in both neuronal and nonneuronal cells of transgenic mice: increased neurofilament density in axons without affecting caliber. J. Cell Biol. 1 11, 1543-1557, 1990.

26. Oshima RG. Intermediatte filament moleculer biology. Curr. Opinion Cell Bial , 4, 110.116, 1992 .

27. Parry DAD, Steinert PM. Intermediate fillament structure. Curr. Opinion Cell Biol. 4, 94-98, 1992

20. Pleper FA, Slobbe RL, Ramaekers FCS, Cuypers HT, Bloemendal H. Upstream regions of the hamster desmim and vimentin genes regulate expression during in witro myogenesis. EMBDO J. 6 . $3611.3618,1987$.

29. Pieper FA, Schaart $G$, Krimpentort $P_{3}$. Henderik JB, Moshage HJ, Wan de Kemp A, Ramaekers FCS, Berns A, Bloemendal H. Transgenic expression of the muscle-specific intermediate fillament protein desmin in nonmuscle cells. J. Cen Biol. $108,1009 \times 1024,1989$.

30. Pieper FA, Van de Klundert FA, Raats JM, Henderik JB, Schaart G, Ramaiekers FCS, Bloemendal H. Regulation of vimentin expression in cultured epithelial cells. Eur. J. Bioch, 210, 509-519. 1992.

31. Pleper FR. Regulation of vimentin and desmin gene expression and intermediate filament formation (thesis). University of Nimegen, The Netherlands, 1993.

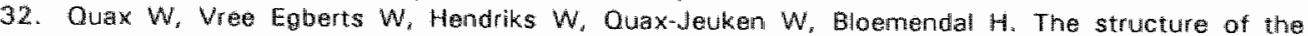
vimentio pene. Cell $35,215 \cdot 223,1983$.

33. Ouax W, Van den Broek L. Vree Egberts W. Pamaekers F, Bloemendal H. Characterization of the desmin gene: expression and formation of desmin filaments in nonmuscle cells after gene transfer. Cell $43,327-338,1985$.

34. Raats IM, Pieper FR, Viree Egberts WT, Verijp KN, Ramaekers FCS, Bloemendal H. Assembly of amino-terminally deleted desmin in vimentin-free cells. J. Cell Biol. 111, 1971-1985, 1990.

35. Raats JM, Henderik JB, Verdijk M, Van Oort FL, Gerafds WL, Ramaekers FCS, Bloemendal H. Assembly of carboxy-terminally deleted desmin in vimentin-free cells. Eur. J. Cell Biol. 56, 84. 
$103,1991$.

36. Raats JM, Gerards WL, Schreuder Mi, Grund C. Henderik JB, Hendraks H. Mamaekars FCS. Bloemendal H. Biochemical and structural aspects of transiantly and stably expressed mutarnt desmir in vimentin-free and vimentin-containing cells. Eur. J. Cetl Biol. 58, 108-127, 1992.

37. Raats JM. Desmin, from protein to intermediate viament (thiesis). University of Nimegen, The Netherlands, 1992 .

38. Ramaekers FCS, Puts JJ, Moesker $\mathrm{O}$, Kant $A$, Huilismans $A$, Haag $D$, Jap PHK, Herman Cu, Vooijs GP. Antibodies to intermediate filament proteins in the immunohistochemical identification of human tumors: an overvew. Histochem. J. 15, 691-713, 1983.

39. Sambrook J, Fritsch EF, Maniatis T. Molecular choming. A laboratory mamual. teds. Ford N, Nolan C) Cold Spring Harbor Laboratory Press, New York, 1989.

40. Schaart $G$, Viebahn $C$, Langmann $H_{s}$ Ramaekers FCS. Desmin and titin expression in early postimplantation mouse embryas. Development 107, 585-596, 1989.

41. Schaart G, Pieper FR, Kulipers HJH, Bloemendal H, Aamaekers FCS. Baby hamster kidney (BHK21/C13/ cells can express striated muscle twpe proteins, Ditterentiation $46,105-115,1991$.

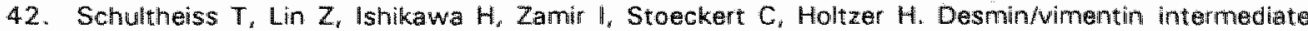
filaments are dispensible for many aspects of myogenesis. J. Celli Biol. 114, 953-966, 1991.

43. Skalli $O$, Goldman RD. Recent insights into the assembly, dynamics, and function of intermediatwe filaments networks. Cell Motil. Cytoskel. 19,67-79, 1991.

44. Steinert PM, Roop DR. The molecular and cellular biology of intermediate filaments. Annu. Rev. Biochem. 57, 593-625, 1988 .

45. Tao $J_{,}$. $\mathrm{W}$. Site-specific antibodies block kinase $A$ phosphorytation of desmin in witro and inhibit the incorporation of myoblasts into myotubes. Cell Motil. Cytoskel. 19, 109-120, 1991.

46. Tokuyasu KT, Maher PA. Singer SJ. Distributions of wimentin and desm in develloping chick myotubes in vivo. I. Immunofluorescence study. J. Cell Biol 98, 1961-1972, 1984.

47. Torpey $\mathrm{N}$. Wylle CC, Heasman J.Function of meternal cytokeratin in Xenopus development. Nature $357,413-415,1992$.

48. Trewor KT. Disruption of keratin filaments in embryonic epthelial cell types. New Biol. 2, 1004 1014,1990 .

49. Van der Klundert FAJM, Raats $J M H$, Bloemendal H. Intermediate filamentsi regulation of gene expression and assembly. Eur. J. Biochem., 1993 (in press!

50. Van der Ven PMJ, Schaart Gi, Jap PHK, Sengers RCA, Stadhouders AM, Ramaekers FCS. Differentiation of human skeletal muscle cells in culture: maturation as indicated by titin and desmin striation. Cell Tissue Res. 270, 189-198, 1992.

51. Vassar $\mathbb{A}$, Coulombe PA. Degenstein L., Albers K. Fuchs E. Mutant keratin expression in transpentic mice causes marked abnormalities resembling a human skin diseasie. Cell 64, 365-380, 1991 .

52. Wigler M, Sweet $A$, Kim GK, Weld B, Pellicer A, Lacy E, Maniatis T, Silverstein $S$, Axel A. Transformation of mammalian cells with genes from procaryotes and eucaryotes. Cill $16,777$. $785,1979$.

53. Wong PC, Cleveland DW. Characterizatian of dominant and recessive assembly-defective mutations in mouse neurafilament NF-M. J. Cell Biol, 111, 1987-2003, 1990. 

SUMMARY/SAMENVATTING 


\section{SUMMARY}

During myofibrillogenesis in wivo as well as in vitro different muscle-specific proteins are expressed at different stages of development. In the first part of this thesis (chapters 1-4) in wivo and in witro myofibrillogenesis and differentiation are studied using immunofluorescence and immunobloting assays. For in vivo developmental studies early postimplantation mouse embryos are used. The expression pattern of desmin and titin is studied in these mouse embryos during different stages of development (8.0-9.5 days of development) in the heart-anlage and the myotomes. Surprisingly, titin is found in the heart rudiment at 8.25 days (Theiler stage 12) in a punctate pattern even betore desmin is expressed in the cardiomyoblasts. During further development of the heart at 8.5 days (Theiler stage 13) titin filaments are formed and at 9.0 days (Theiler stage 14) titin cross-striation is detected before desmin cross-striation can be observed. At 9.5 days (Theiler stage 14) also desmin crossstriation was seen in the heart muscle cells. One conclusion from this mouse embryo study is that titin is an earlier marker for cross-striated muscle differentiation than desmin.

To further examine the expression patterns of muscle-specific proteins, in vitro hamster muscle cells (BHK21/C13; chapter 2) and human skeletal muscle cells (chapter 3) are studied at several stages of differentiation. In undifferentiated BHK-21/C13 cells and human skeletal myoblasts desmin is detected in a filamentous pattern. None of the specific sarcomeric proteins such as titin, nebulin, sarcomeric myosin, or the tropomyosins can be detected in these undifferentiated cells. Both cell types are induced to differentiate by changing the culture medium from a high nutrition medium to a low nutrition medium. The BHK-21/C13 cells than differentiate from a polygonal phenotype to a more elongated form. The human skeletal muscle cells form myotubes during this in vitro differentiation process. Early in the differentiation process of both cell types, first the typical punctated titin expression pattern is seen before other sarcomeric proteins can be detected. Later, in elongated BHK-21/C13 cells and in matured skeletal muscle myotubes, titin is observed in a cross-striated pattern, again before other proteins assembled into a striated pattern. Confirmatory results are obtained from immunoblotting assays and by two-dimensional gel electrophoresis studies. The expression of titin during in vitro myofibrillogenesis confirms the results found in the in vivo model: titin is one of the first myofibrillar proteins expressed in differentiating muscle cells. Furthermore, the sequential stages of assembly of this protein show that titin is of great importance for arranging other sarcomeric proteins.

In chapter 4 the first characterization of cardiotin is described. The distribution pattern of cardiotin, a structural component of the myocard, is compared to that of other sarcomeric constituents and the sarcoplasmic reticulum in several species and tissues. Cardiotin is localized between the myofibrils of the cardiomyocytes, perpendicularly to the typical cross-striations, for example observed with antibodies to titin and desmin. This localization of cardiotin suggests a passible link with the sarcoplasmic reticulum. In immumoblotting assays cardiotin is detected at a molecular weight of approximately $300 \mathrm{kDa}$ and is classified as a giant muscle protein like titin and nebulin. Cardiotin seems to be expressed late in the progress of muscle cell differentiation, in fact only (several months) after birth.

In the second part of this thesis (chapters 5 - 7) the expression patterns of truncated hamster desmin and vimentin in transgenic mice are described. The functional role of desmin and wimentin intermediate filaments in the context of (muscle) tissue differentiation is examined by expression of various intermediate filament gene constructs and the disruption of endogenous desmin and vimentin networks in transgenic mice. The vimentin-desmin hybrid gene constructs pVVim2 (chapter 5) and pVDes (chapter 6 ) are expressed in all vimentin-containing cells of transgenic mice. This results in hybrid intermediate filament formation, but has no effect on normal 
differentiation or development of the mice. The gene constructs encoding a carboxyterminally deleted mutant desmin subunit driven by the desmin or the vimentin promoter, pDDV and pVDV respectively (chapter 7), also cause no detectable developmental, morphological, and functional abnomalities, although disruption of desmin and vimentin filaments is seen in part of the cells in the tissues. In contrast to the expression leveis of constructs pVVim2 and pVDes, the pVDV construct is expressed in a small percentage of vimentin-containing cells, and surprisingly also in a small percentage of cross-striated muscle cells. The pDDV construct is only detected in a small percentage of striated muscle cells but not in smooth muscle cills. In conclusion, several truncated mutant desmin subunits cause distuption of intermediate filament networks in mesenchymal tissues, while no functional, developmental, and morphological abnormalities in the animals are detected. 


\section{SAMENVATTING}

Tijdens de spierontwikkeling worden, zowel in wivo als in witro, verschillende spierspecifieke eivitten op verschillende momenten van dit ontwikkelingsproces aangeschakeld. In het eerste gedeelte van dit proetschrift thoofdstukken $1-4$ ) worden de spierontwikkeling en spierdifferentilatie in wivo en in vitro, beschreven aan de hand van de expressie van spierspecifieke komponenten met behulp van immunofluarescentie- en immunoblottingexperimenten.

Voor de in vivo experimenten zijn muize-embryo s van verschillende leeftijden $18.0-9,5$ dagen bestudeerd. Hierbij is gekeken naar het expressiepatroon van met name desmine en titine in het zich ontwikkelende embryonale hart en in de myotomen. Het is opvallend, dat in het rudimentaire hart (dag 8.25 ) titine in de vorm van kleine aggregaten voorkomt, nog voordat desmine kan worden gedetekteerd. In een later stadium van de ontwikkeling van het embryonale hart $($ dag 8 ,5) vormt titine filamenten in de cardiomyocyten en op dag 9,0 wordt voor het eerst titine-dwarsstreping wargenomen. Dwarsstreping van desmine wordt voor het eerst op dag 9.5 in het cumbryonale muzehart gevonden. In de myotomen wordt een identieke volgorde van expressiepatronen van deze eiwitten waargenomen. Uit deze studie kan gekonkludeerd worden dat in het muize-embryo titine een vroegere marker voor dwarsgestreepte spierceldifferentiatie is dan desmine, hetgeen eerder beschreven is.

In gekweekte hamster spiercellen (BHK21/C 13; hoofdstuk 2) en gekweekte humane skeletspiercellen (hoofdstuk 3 ) is gekeken naar het expressiepatroon van spierspecifieke eiwitten vóbr, tijdens en na het induceren van differentiatie. In ongedifferentieerde BHK21/C13 cellen en humane skeletspiercellen wordt desmine waargenomen in een filamenteuze vorm. Er worden geen andere sarcomeer-specifieke eiwitten, zoals titine, nebuline, sarcomeer specifiek myosine of tropomyosines gevonden in deze cellen. Beide celtypen kunnen in vitro worden geinduceerd tot differentiatie door het voedingsrijke kweekmedium waarin deze cellen normaal prolifereren te vervangen door een voedselarm medium. Na deze 'medium-switch', differentieren de polygonale BHK21/C13 cellen tot een geëlongeerd fenotype. De humane skeletspiercellen fuseren in vitro tot myotubes. Tijdens de eerste fase van differentiatie vertonen beide celtypen een gepunkteerd titine patroon, dat eerder dan andere sarcomeer-specifieke eiwitten tot expressie komt. Gedurende het differentiatieproces wordt titine-dwarsstreping waargenomen nog voordat andere spierspecifieke eiwitten in een dergelijk patroon voorkomen. Deze volgorde van aanmaak van verschillende eiwitkomponenten tijdens het differentiatieproces wordt eveneens gevonden met behulp van immunablotting- en tweedimensionale gelelektroforese technieken. Het expressiepatroon van titine tijdans de spierontwikketing in vitro, is te vergelijken met de resultaten die gevonden worden in het muize-embryo model (hoofdstuk 1): titine is het eerste eiwit dat zijn plaats vindt in de zich vormende sarcomeren en het lijkt van belang te zijn voor de assemblage en rangschikking van andere sarcomeer-specifieke eiwitten, zoals actine, myosine, tropomyosine en desmine.

In hoofdstuk 4 wordt de karakterisatie van cardiotine beschreven, een nieuwe strukturele eiwitkomponent in het myocard. De cardiotine-distributie in het hart wordt vergeleken met die van andere dwarsgestreepte spierspecifieke eiwitten en met de stiruktuur van het sarcoplasmatisch reticulum, in zowel verschillende weefsels als in verschillende species. Cardiotine is gelokaliseerd tussen de myofibrillen van de cardiomyocyt, loodrecht op de zo karakteristieke dwarsstreping die wordt gezien met antisera gericht tegen bijvoorbeeld titine of desmine. De lokalisatie van cardiotine wijst op een mogelijk verband met het sarcoplasmatisch reticulum. Cardiotine heeft op een SDS-polyacrylamide gel een molekuulgewicht van ongeveer $300 \mathrm{kDa}$ en wordt, evenals titine en nebuline, beschouwd als één wan de zeer grote strukturele spiereiwitten. Cardiotine komt laat tot expressie, namelijk pas (enkele maanden) na de geboorte.

In het tweede gedeelte van dit proefschrift hoofdstukken 5-71. wordt het expressie- 
patroon van gemuteerd desmine en vimentine in transgene muizen beschreven. Door verschillende gemuteerde desmine-vimentine hybriden transgeen in muizen tot expressie te laten komen vindt een verstoring van endogene desmine en vimentine filamenten plaats. Hierdoor kan de funktie van deze filamenten tijdens de ontwikkeling en differentiatie van (spier-/weefsel worden bestudeerd.

Desmine-vimentine konstrukten geplaatst onder kontrole van de wimentine promoter: komen tot expressie in alle vimentine bevattende cellen. Dergelijke mutante hybriden onder kontrole van de desmine promoter worden uitsluitend waargenomen in een klein percentage dwarsgestreepte spiercellen en niet in gladde spiercellen. Deze konstrukten, zowel onder kontrole van de vimentine promoter als de desmine promoter, hadden echter geen waarneembaar (negatief) effekt op het ontwikkellings- en differentiatieproces van de muizen. Konkluderend kan gezegd worden, dat door het tot expressie brengen van verscheidene gemuteerde desmine-vimentine hybriden. verstoring van intermediaire filament-netwerken in cellen van mesenchymalle origine veroorzaakt kan worden zonder dat in deze cellen of weefsels funktionele of morfologische afwijkingen kunnen worden waargenomen. 


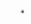




\section{DANKWOORD}

ledereen die een bijdrage heeft geleverd aan de totstandkoming van dit proefschrift will ik graag bedanken.

Medewerkers van het instituut voor Pathologie van het St. Radboudziekenhuis te Nijmegen, bedankt voor de prettige samenwerking tijdens mijn "Nijmeegse" periode. In het bijzonder bedank ik mijn collega's van de Filamentengroep. niet alleen voor de fijne werksfeer en voor alle steun die ik in het begin van mijn promotietijd van jullie kreeg. maar ook voor de gezelligheid buiten werktijd.

Piet Spaan en Hendrik Jan Janssen van het Centraal Dierenlaboratorium van de Katholieke Universiteit Nijmegen (KUN), heel veel dank voor jullie deskundigheid en assistentie bij het uitvoeren van de dierexperimenten.

De medewerkers van de afdeling Medische Fotografie van de KUN, wil ik danken voor het opnemen van de vele gels en blots, voor het ontwikkelen van honderden films en voor de deskundige adviezen bij het afdrukken van de foto's.

Frank Pieper en Jos Raats van de afdeling Biochemie van de KUN, dank ik voor de totstandkoming van een aantal artikelen die terug te vinden zijn in dit proefschrift.

Peter van der Ven van de afdeling Celbiologie \& Histologie van de KUN, woor de altijd collegiale samenwerking, resulterend in hoofdstuk 3 van dit proefschrift en voor de gezelligheild die we hadden op twee splercongressen nogmaals 'gggerzliggen dankggg'.

Helma Langmann und Christoph Viebahn vom Institut für Anatomie der Universität Bonn. danke ich vielmals für Ihre Gastfreundschaft im 'Affenkäfig'. Ihre Hilfe bei den Färbungen von den Embryonenschnitten, sowie deren mikroskopischen Auswertungen waren für mich unentbehrlich, ebenso wie die köstlichen Kuchen.

Collega's van de vakgroep Moleculaire Celbiologie \& Genetica van de Rijksuniversiteit Limburg te Maastricht, reuze bedankt voor jullie belangstelling, ondersteuning en gezelligheid tijdens de periode dat ik als "anavendus' ofwel "promolist" met jullie heb samengewerkt.

Frank van der Loop, kamergenoot en paranimf, dank ik niet alleen voor de goede samenwerking, maar ook voor de gezelligheid en vriendschap in Sesamstraat 5.238.

Robbin Westerhof, paranimf, niet alleen voor je grote belangstelling voor mijn onderzoek, maar vooral ook voor de hechte vriendschap, hartelijk bedankt.

Mijn promotor, Frans Ramaekers, stimulator van dit promotie-onderzoek, dank je wel voor je nimmer aflatende enthousiasme, zowel tijdens het "filamenten tijdperk" in Nijmegen, als ook in de huidige MCB-club te Maastricht, waar je mij ook na mijn promotie de mogelijkheid geeft nog een aantal jaren als post-doc te werken.

Familieleden en vrienden wil ik bedanken voor de interesse in het reilen en zeilen van dit promotie-onderzoek.

Lieve Helma, bedankt. 



\section{CURRICULUM VITAE}

Gert Schaart werd geboren op 22 februari 1960 te Elst (Gld.). Na het behalen van het HAVO-diploma aan thet Heldring College te Zetten in 1978, volgde hij van 1978 tot 1982 de laboratoriumopleiding HBO-A (medisch) en van 1980 tot 1983 de laboratoriumopleiding HBO-B (chemisch) respektievelijk aan de Opleiding woor Laboratoriumpersoneel Arnhem-Nijmegen (afstudeerrichting:" mikroskopische technieken) en aan de Hogere en Middelbare Laboratoriumschool te Oss (afstudeerrichting: biochemie).

Van mei 1983 tot juni 1991 werkte hij als research-analist binnen het instituut voor Pathologie (hoofd: Prof. Dr. G.P. Vooijs) van het Academisch Ziekenhuis St. Radboud te Nijmegen onder leiding van Dr. F.C.S. Ramaekers.

Sinds juni 1991 is hij aangesteld bij de vakgroep Moleculaire Celbiologie \& Genetica (hoofd: Prof. Dr. F.C.S. Ramaekers) van de Rijksuniversiteit Limburg (RL) als onderzoeksassistent. Hij participeerde in het onderwijs voor studenten van de Faculteiten Geneeskunde en Gezondheidswetenschappen van de RL. Sinds 1989 is hij kursusleider bij het Trainingscentrum Medische Biotechnologie aan die Hogeschool West-Brabant te Etten. Leur.

Met ingang van 1 december 1993 is hij werkzaam op een door de Nederlandse Hartstichting gesubsidieerd onderzoeksprojekt.

Gert Schaart is sinds september 1993 gehuwd met Helma Kuijpers. 



\section{PUBLICATIONS}

Ramaekers F, Huijsmans A, Moesker O. Schaart G, Herman C Vooijs P. Cytokeratin expression during neoplastic progression of human transitional cell carcinomas as detected by a monoclonal and polyclonal antibody. Lab. Invest. $52,31-38,1985$.

Ramaekers F, Feitz W, Moesker O, Schaart G, Herman C, Debruyne F, Vooils P. Antibodies to cytokeratin and vimentin in testicular tumour diagnosis. Virch. Arch. A $408,127-142,1985$.

Ramaekers FCS, Moesker O, Huijsmans A, Schaart G. Westerhof GR, Wagenaar SjSc. Herman $C J$, Vooijs GP. Intermediate filament proteins in the study of tumors of the urinary and respiratory tracts. In: intermediate Filaments leds. Wang $E$. Fischman $D$, Liem RKH, Sun TTh. Ann. N.Y. Acad. Sci. 455, 614-634, 1985.

Broers JLV, Carney DN, Klein Rot M, Schaart G, Lane EB, Vooijs GP, Ramaekers FCS. Intermediate filament proteins in classic and variant types of small cell lung carcinoma cell lines: a biochemical and immunochemical analysis using a panell of monoclonal and polyclonal antibodies. J. Cell Sci. 83, 37-60, 1986.

Broers JLV, Gropp C, Beppler G, Klein Rot M, Beck J, Schaart G, Vooijs GP, Ramaokers FCS. Identification of cytoskeletal structures in hormone producing lung cancer cell cultures. Acta Histochem. 34, 57-75, 1987.

Ramaekers FCS, Huijsmans A, Schaart G, Moesker O, Vooijs GP. Cytoskeletal proteins as markers in surgical pathology. In: Application of monoclonal antibodies in tumor pathology (eds. Ruiter DJ. Fleuren GJ, Warnaar Soj. Martinus Nijhoff Publishers Dordrecht. 65-85, 1987.

Ramaekers F, Huijsmans A, Schaart $G$, Moesker $D$, Vooijs $P$. Tissue distribution of keratin 7 as monitored by a monoclonal antibody. Exp. Cell Res. 170, 235-249, 1987.

Heuvel R van den, Van Eys G, Ramaekers $F$, Quax W, Vree Egberts $W$, Schaart G, Cuijpers $T$. Bloemendal $H$. Intermediate filament formation after transfection with modified vimentin and desmin genes. J. Cell Sci. 88, 475-482, 1987 .

Krimpenfort PJ, Schaart G, Pieper FR, Ramaekers FCS, Cuijpers HT, Van den Heuvel RM, Vree Egberts WT, Van Eys GJ, Berns A, Bloemendal H. Tissue-specific expression of a vimentin-desmin hybtid gene in transgenic mice. EMBO J. 7, 941-947, 1988.

Pieper FR, Krimpenfort PJ. Ramaekers FCS, Schaart G. Van Eys G., Berns A. Bloemendal $H$. Tissue-speecific expression of an intermediate filament hybrid gene in transgenic mice. In: Structure and Functions of the Cytoskelet. (ed. Rousset BAFI John Libbey Eurotext, Vol. 171, 163-168, 1988.

Pieper FR, Schaart G, Krimpenfort PJ. Henderik JB, Moshage H. Van de Kemp A, Ramaekers FC, Berns A, Bloemendal H. Transgenic expression of the muscle-specific intermediate filament protein in nonmuscle cells. J. Cell Biol. 108, 1009-1024, 1989. 
Famakers FCS, Verhagen APM, lsaacs JT. Felt WFJ, Moesker O, Schaart G, Schalken JA, Vooijs GP. Intermediate filament expression and the progression of prostatic cancer as studied in the Dunning $\mathrm{P}-3327$ rat prostatic carcinoma system. The Prostate 14, 323-339, 1989.

Schaart $G$, Viebahn $C$. Langmann $H$, Ramaekers $F$. Desmin and titin expression in early postimplantation mouse embryos. Development 107, 585-596, 1989.

Versnel MA, Hoogsteden HC. Hagemeijer A, Bouts MJ, Van der Kwast TH, Delahaye M. Schaart G. Ramaekers FCS. Characterization of three human malignant mesothelioma cell lines. Canc. Genet. Cytogen. $42,115-128,1990$.

Ramaekers F, Van Niekerk C, Poels L, Schaafsma E, Huijsmans A, Robben H, Schaart G. Vooijs P. Use of monoclonal antibodies to keratin 7 in the differential diagnosis of adenocarcinomas. Arm. J. Path. 136, 641-655, 1990

Van Eyken P, Sciot R, Callea F, Ramaekers F, Schaart $G$, Desmet VJ. A cytokeratinimmunochemical study of hepatoblastoma. Hum. Path. 21, 302-308, 1990.

Biroers JLV, Mijnheere EP, Klein Rot M, Schaart G, Sijlmans A, Boerman OC, Ramaekers FCS. Novel antigens characteristic of neuroendocrine malignancies. Cancer 67,619$633,1991$.

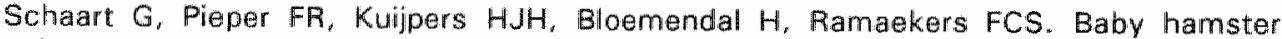
kidney (BHK-21/C 13) cells can express striated muscle type proteins. Differentiation $46,105-115,1991$.

Van der Loop FTL, Schaart G, Langmann W, Ramaokers FCS, Viebahn C. Expression and organization of muscle specific proteins during the early developmental stages of the rabbit heart.. Anat. Embryol. 185, 439-450, 1992.

Slager HG, Good MJ, Schaart G. Groenewoud JS, Mummery CL. Organization of nonmuscle myosin during early murine embryonic differentiation. Differentiation 50, 47-56. 1992.

Van der Ven PFM, Schaart G. Jap PHK, Sengers RCA, Stadhouders AM, Ramaekers FCS. Differentiation of human skeletal muscle cells in culture: maturation as indicated by titin and desmin striation. Cell Tissue Res. 270, 189-198, 1992.

Pleper FR, Van de Klundert FA, Raats JM, Henderik JB, Schaart G, Ramaekers FCS, Bloemendal $H$. Regulation of vimentin expression in cultured epithelial cells. Eur. J. Bioch. 210, 509-519, 1992.

Schaart $G$, Van der Ven PFM, Ramaekers FCS. Characterization of cardiotin, a structural component in the myocard. Eur. J. Cell Bioll. 62, 34-48, 1993.

Van der Ven PFM, Schaart G, Croes HJE, Jap PHK, Ginsel LA, Ramaekers FCS. Titin aggregates associated with intermediate filaments align along stress fiber-like structures during human skeletal muscle cell differentiation. J. Cell Sci. (in press), 1993. 